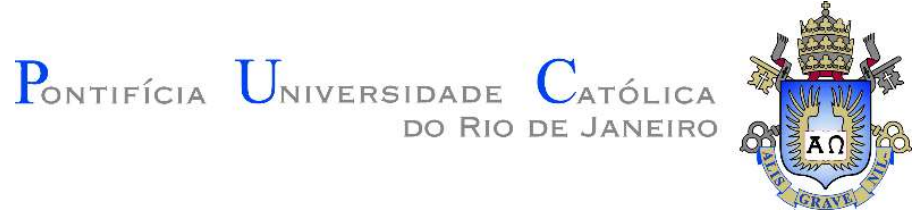

Vitor Moreira de Alencar Monteiro

\title{
Comportamento Mecânico e Controle de Qualidade do Concreto Projetado com Fibras no Revestimento de Túneis da Mina Cuiabá
}

Dissertação apresentada como requisito parcial para obtenção do grau de Mestre pelo Programa de PósGraduação em Engenharia Civil do departamento de Engenharia Civil e Ambiental da PUC-Rio.

Orientador: Prof. Flávio de Andrade Silva

Rio de Janeiro

Fevereiro de 2020 


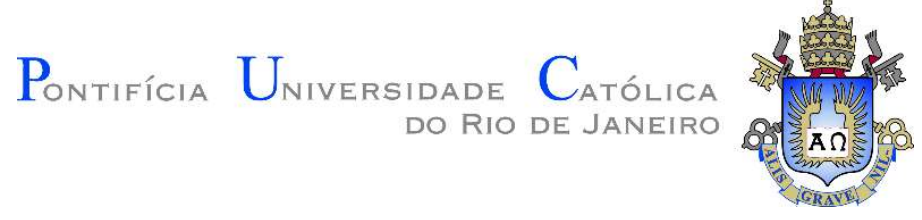

Vitor Moreira de Alencar Monteiro

\section{Comportamento Mecânico e Controle de Qualidade do Concreto Projetado com Fibras no Revestimento de Túneis da Mina \\ Cuiabá}

Dissertação apresentada como requisito parcial para obtenção do grau de Mestre pelo Programa de Pós-Graduação em Engenharia Civil da PUC-Rio. Aprovada pela Comissão Examinadora abaixo.

Prof. Flávio de Andrade Silva Orientador Departamento de Engenharia Civil e Ambiental - PUC-Rio

Prof. Daniel Carlos Taissum Cardoso Departamento de Engenharia Civil e Ambiental - PUC-Rio

Prof. Luís Antônio Guimarães Bitencourt Júnior Departamento de Engenharia de Estruturas e Geotécnica - USP-SP 
Todos os direitos reservados. É proibida a reprodução total ou parcial do trabalho sem autorização da universidade, do autor e do orientador.

Vitor Moreira de Alencar Monteiro

Graduado em Engenharia Civil pela Pontifícia Universidade Católica do Rio de Janeiro - PUC-Rio - em 2018.

Ficha Catalográfica

Monteiro, Vitor Moreira de Alencar

Comportamento mecânico e controle de qualidade do concreto projetado com fibras no revestimento de túneis da Mina Cuiabá / Vitor Moreira de Alencar Monteiro; orientador: Flávio de Andrade Silva. - 2020.

158 f. : il. color. ; $30 \mathrm{~cm}$

Dissertação (mestrado)-Pontifícia Universidade Católica do Rio de Janeiro, Departamento de Engenharia Civil e Ambiental, 2020.

Inclui bibliografia

1. Engenharia Civil e Ambiental - Teses. 2. Concreto projetado com fibras. 3. Sistemas de suporte. 4. Comportamento mecânico. 5. Controle tecnológico. 6. Ensaio de duplo puncionamento. I. Silva, Flávio de Andrade. II. Pontifícia Universidade Católica do Rio de Janeiro. Departamento de Engenharia Civil e Ambiental. III. Título. 


\section{Agradecimentos}

Gostaria de agradecer, em primeiro lugar, aos meus pais Monica e José Jorge e ao meu avô Lee por sempre me apoiarem nas minhas decisões e sempre estarem comigo nos momentos mais importantes da minha vida. Também à minha prima Erica pela amizade e pelos conselhos. À minha namorada Juliana, que se tonou minha companheira durante a execução desse trabalho. Obrigado pelo carinho e pelos incríveis momentos juntos.

Ao meu orientador Flavio, agradeço por sempre acreditar no meu trabalho desde o início quando ainda era um aluno de iniciação científica. Tenho certeza que cresci muito profissionalmente com o suporte e com os conselhos recebidos durante todos os anos de trabalho no laboratório.

Agradecer imensamente toda a equipe de funcionários do Laboratório de Estruturas e Materiais da PUC-Rio pelo auxílio fundamental prestado durante essa pesquisa. Em especial ao técnico Euclides, por estar sempre junto comigo no desenvolvimento dos ensaios mecânicos ao longo de todo esse tempo.

Aos amigos da PUC-Rio, que além de me proporcionar vários momentos de alegria durante os últimos anos, também foram fundamentais o desenvolvimento do meu trabalho.

À equipe da AngloGold Ashanti que trabalha na mina Cuiabá pelo envio dos materiais, das amostras e pela parceria durante essa pesquisa.

À equipe da Belgo Bekaert Arames por ter acreditado no meu trabalho e me chamado para participar do Workshop em Jacobina, além do incentivo para o desenvolvimento desse trabalho na área de mineração.

Ao CNPq e à FAPERJ pelo suporte financeiro para a realização dessa pesquisa. 


\section{Resumo}

Monteiro, Vitor Moreira de Alencar; Silva, Flávio de Andrade (Orientador). Comportamento Mecânico e Controle de Qualidade do Concreto Projetado com Fibras no Revestimento de Túneis da Mina Cuiabá. Rio de Janeiro, 2020. 158 p. Dissertação de Mestrado - Departamento de Engenharia Civil e Ambiental, Pontifícia Universidade Católica do Rio de Janeiro.

O presente trabalho investigou o comportamento mecânico do concreto projetado com fibras aplicado nas escavações da mina Cuiabá e o seu controle tecnológico através do ensaio de duplo puncionamento. Para essa pesquisa utilizouse o traço desenvolvido pelos engenheiros da mina Cuiabá com dois tipos diferentes de fibra sintética e uma fibra de aço. Inicialmente, caracterizou-se o material compósito através de ensaios de flexão em prismas (EN 14651) e de arrancamento. Em seguida, os resultados obtidos foram utilizados em conjunto com os ensaios de flexão em painéis circulares (ASTM C1550), quadrados (EN 14488-5) e de larga escala para o dimensionamento do sistema de suporte utilizado na mina Cuiabá. As frações mais baixas de fibras sintéticas são mais indicadas nos locais onde a qualidade da rocha é razoável ou boa, enquanto as fibras de aço podem ser aplicadas onde a qualidade do maciço rochoso é classificada como muito fraca. Em relação ao controle tecnológico do concreto com fibras, os ensaios de duplo puncionamento realizados em máquinas mais rígidas são mais eficientes em diminuir a extensão da instabilidade pós-fissuração, limitar os erros nas correlações com os ensaios de flexão (EN 14651) e em reduzir a variação das propriedades mecânicas do material. A aplicação do ensaio de duplo puncionamento com controle fechado pela corrente extensométrica foi o método mais efetivo em limitar a instabilidade pós-fissuração independente da máquina de ensaios selecionada.

\section{Palavras-chave}

Concreto Projetado; Comportamento Mecânico; Controle de Qualidade; Ensaio de Duplo Puncionamento; Sistemas de Suporte; Fibras de Aço e Sintéticas; Sistemas de Controle 


\begin{abstract}
Monteiro, Vitor Moreira de Alencar; Silva, Flávio de Andrade (Advisor). Mechanical Behaviour and Quality Control of the Fiber Reinforced Shotcrete Applied as Rock Support at the Cuiaba Mine Excavation. Rio de Janeiro, 2020. 158 p. Dissertação de Mestrado - Departamento de Engenharia Civil e Ambiental, Pontifícia Universidade Católica do Rio de Janeiro.
\end{abstract}

The present work investigated the mechanical behavior of the fiber reinforced shotcrete applied at the Cuiabá mine excavation and its quality control through the double punch test. For this research, the mix composition was developed by Cuiabá mine Engineers with the addition of two different types of synthetic fibers and one steel fiber. Firstly, the cement based composite was studied at the material level through bending (EN 14651) and pullout tests. Thereafter, the support system of the Cuiabá mine excavation was designed based on round (ASTM C1550), square (EN 14488-5) and large scale panel tests. The application of lower synthetic fiber volume fractions was more suited for the areas with good quality rock indexes, while steel fibers were better suited at field with lower rock classes. Regarding the quality control of FRC, the double punch tests that were conducted in stiffer testing machines were more effective in reducing the post-peak instability, in limiting the errors in the correlations with bending tests (EN 14651) and in reducing the mechanical properties variations of the material. Finally, the application of the double punch test with closed-loop control of the circumferential extensometer turned to be the most effective method in limiting the post-peak instability regardless of the selected machine.

\title{
Keywords
}

Shotcrete; Mechanical Behavior; Quality Control; Double Punch Test; Support System; Steel and Synthetic Fibers; Control System Methodology 


\section{Sumário}

1 Introdução 22

1.1. Panorama Geral 22

1.2. Objetivos 23

1.3. Estrutura da Dissertação 24

2 Revisão bibliográfica $\quad 27$

2.1. Sistema de suporte e reforço $\quad 27$

2.1.1. Terminologia 27

2.1.2. Princípios de atuação 28

2.2. Teoria do concreto projetado 31

2.2.1. Mecanismos de atuação 31

2.2.2. Mecanismos de ruptura 36

2.3. Desenvolvimento do traço 38

2.3.1. Componentes 38

2.3.2. Dosagem do concreto projetado 40

2.3.3. Tipos de fibra 41

2.4. Dimensionamento do concreto projetado 42

2.5. Comportamento mecânico do concreto projetado 47

2.6. Ensaio de duplo puncionamento (Barcelona) 57

2.6.1. Configuração e aplicação

2.6.2. Correlação entre o ensaio de Barcelona e o ensaio de flexão em prismas $\quad 59$

2.6.3. Sistemas de controle para o ensaio de duplo puncionamento 61

3 Escavação na mina Cuiabá 66

3.1. Introdução 66

3.2. Síntese histórica 66

3.3. Caracterização geológica e geotécnica 67

3.4. Sistemas de suporte e reforço aplicados na mina Cuiabá 70

3.5. Controle tecnológico do concreto projetado da mina Cuiabá 71 
4 Caracterização dos materiais $\quad 75$

4.1. Introdução 75

4.2. Materiais e dosagem 75

4.3. Procedimento de mistura 78

$\begin{array}{ll}\text { 4.3.1. Moldagem em laboratório } & 78\end{array}$

$\begin{array}{ll}\text { 4.3.2. Moldagem na mina Cuiabá } & 78\end{array}$

4.4. Fibras $\quad 79$

5 Comportamento mecânico do concreto projetado com fibras no revestimento de túneis $\quad 82$

5.1. Introdução

5.2. Programa experimental 83

5.3. Fabricação das amostras $\quad 84$

5.4. Ensaios mecânicos $\quad 86$

5.4.1. Ensaios de arrancamento $\quad 86$

5.4.2. Ensaios de flexão em prismas $\quad 88$

5.4.3. Ensaios de flexão em painéis circulares 90

5.4.4. Ensaios de flexão em painéis quadrados 92

5.4.5. Ensaios de flexão em painéis de larga escala 93

5.5. Resultados e discussões 95

5.5.1. Caracterização do concreto reforçado com fibras 95

5.5.2. Classificação do concreto com fibras a partir de ensaios de flexão em $\begin{array}{ll}\text { painéis } & 101\end{array}$

5.5.3. Influência das condições de contorno na resposta mecânica dos ensaios de flexão em painéis 105

5.5.4. Comportamento mecânico do concreto com fibras em ensaios $\begin{array}{ll}\text { de flexão em painéis de larga escala } & 108\end{array}$ 5.6. Conclusão

6 Controle de qualidade do concreto com fibras através do ensaio de duplo puncionamento

6.1. Introdução 
6.2. Programa experimental 116

6.3. Fabricação das amostras 116

6.4. Ensaios mecânicos 117

6.4.1. Ensaio de duplo puncionamento 117

6.4.2. Máquinas de ensaio universal 119

6.5. Resultados e discussões 122

6.5.1. Influência da rigidez da máquina de testes universais na extensão da instabilidade pós-pico e nas propriedades mecânicas do concreto reforçado com fibras

6.5.2. Influência da rigidez da máquina de testes universais na correlação

entre os ensaios de duplo puncionamento e flexão em três pontos para o concreto reforçado com fibras

6.5.2.1. Equivalência entre os ensaios de duplo puncionamento e flexão em três pontos

6.5.2.2. Correlação para tenacidade entre os ensaios de duplo puncionamento

$\left(\mathrm{E}_{\mathrm{BCN}}\right)$ e flexão em três pontos $\left(\mathrm{T}_{\mathrm{EN}}\right)$

6.5.2.3. Correlação para tensões residuais entre os ensaios de duplo

puncionamento $\left(\mathrm{f}_{\mathrm{ct}, \mathrm{Rx}}\right)$ e flexão em três pontos $\left(\mathrm{F}_{\mathrm{R}, \mathrm{j}}\right)$

6.5.3. Influência do tipo de controle das máquinas de ensaio universal na extensão da instabilidade pós-pico e nas propriedades mecânicas do concreto reforçado com fibras

6.6. Conclusão

7 Conclusão

8 Referências bibliográfica 


\section{Lista de figuras}

Figura 1 - Estrutura da dissertação de mestrado

Figura 2 - Princípios de (a) reforço e (b) suporte de rocha. Adaptado

de Hudson \& Harrison [3]

28

Figura 3 - Princípio de atuação de suporte ou reforço: (a) exemplo

hipotético de avanço de escavação do túnel com instalação de sistema de suporte a cada ciclo de escavação e (b) Gráfico de pressão radialdeslocamento do maciço rochoso e do sistema de suporte.

Adaptado de Brady \& Brown [2]

Figura 4 - Ilustração da influência da rigidez do suporte e do momento da instalação do sistema de suporte. Adaptado de Brady \& Brown [2]

Figura 5 - Curvas de reação de diferentes tipos de sistema de suporte.

Adaptado de Brady \& Brown [2]

Figura 6 - Concreto projetado em compressão depois da aplicação até (a) piso e (b) por todo o túnel. Adaptado de Hadjigeorgiou \& Ptovin [4]

Figura 7 - Concreto projetado em compressão depois de sua aplicação que termina acima do piso do túnel como feito em obras de mineração. Adaptado de Hadjigeorgiou \& Ptovin [4]

Figura 8 - Ilustração do mecanismo de engrenamento dos blocos de rocha: (a) engrenamento devido à aderência, (b) desenvolvimento de resistência ao cisalhamento com pouca aderência do concreto, (c) penetração do concreto entre as juntas da rocha, (d) resistência ao cisalhamento para uma camada espessa de concreto e (e) contenção do movimento dos blocos devido à tração na flexão do revestimento.

Adaptado de Hadjigeorgiou \& Ptovin [4]

Figura 9 - Mecanismos de atuação do concreto: (a) cesta,

(b) arco estrutural e (c) reforço dos planos de fraqueza.

Adaptado de Hadjigeorgiou \& Ptovin [4]

Figura 10 - Mecanismos de falha do concreto projetado.

Adaptado por Morton [13]

Figura 11 - Flexão do concreto projetado após perda de aderência. 
Adaptado de Seymour et al. [9]

Figura 12 - Faixa de distribuição granulométrica recomendada pela EFNARC [19]

Figura 13 - Contenção das deformações da rocha com

a ação combinada do concreto projetado e dos tirantes.

Adaptado de Martin et al. [37]

Figura 14 - Dimensionamento de suporte e reforço para

túnel circular com 7,3 m de diâmetro de acordo com o método RSR.

Adaptado de Hoek [41]

Figura 15 - Dimensionamento do sistema de suporte a partir

da classificação pelo sistema Q a partir de Grimstad \& Barton [40]

(Palmstrom \& Broch [47])

46

Figura 16 - Conceitos de hardening e softening para a classificação do comportamento mecânico do concreto com fibras.

Adaptado de Mobasher [68]

Figura 17 - Resultados publicados de tenacidade em painéis circulares

(ASTM C1550 [49]) para o concreto projetado reforçado com fibras (a)

sintéticas e (b) de aço

Figura 18 - Comparação entre a aplicação de (a) concreto

projetado com fibras e (b) concreto projetado com tela metálica.

Adaptado de Vandewalle [70]

Figura 19 - Configurações de setup propostos por

Fernandez Delgado et al [10]: (a) plana, (b) em formato de arco e

(c) arco com centro irregular.

Adaptado de Fernandez Delgado et al [10])

Figura 20 - Modos de falha observados por Fernandez Delgado et al [10]:

(a) perda de aderência, (b) ruptura por cisalhamento e (c) ruptura por flexão.

Adaptado de Fernandez Delgado et al. [10]

Figura 21 - Arranjo experimental desenvolvido por Martin et al. [37] para

ensaios de flexão em larga escala em concreto projetado em combinação com tirantes e tela soldada: (a) antes e (b) depois da realização do ensaio.

Figura 22 - Arranjo experimental usado por Morton [13] para ensaios de flexão em larga escala. 
Figura 23 - Configuração do ensaio de duplo puncionamento

Figura 24 - Diferentes estágio da falha de uma amostra durante o ensaio de Barcelona. Adaptado de Pujadas [77]

Figura 25 - Curva típica obtida após o ensaio de Barcelona dividia nos estágios I,II e III. Adaptado de Pujadas [77]

Figura 26 - Extensão da instabilidade na curva Força por TCOD do ensaio de Barcelona. Adaptado de Simão [91]

Figura 27 - Diferentes tipos de controle: (a) aberto (open-loop) e (b) fechado (closed-loop). Adaptado de Mobasher [68]

Figura 28 - Esquema de sistema aberto (open-loop) em um ensaio de flexão controlado pelo deslocamento do atuador. Adaptado de Bernard [94]

Figura 29 - Esquema de sistema fechado (closed-loop) em um ensaio de flexão controlado pelo deslocamento do atuador.

Adaptado de Bernard [94]

Figura 30 - Esquema de sistema fechado (closed-loop) em um ensaio de flexão controlado pelo deformação do corpo de prova.

Adaptado de Bernard [94]

Figura 31 - Mapa geológico simplificado das principais estruturas do Rio das Velhas Greenstone Belt incluído no Quadrilátero Ferrífero.

Adaptado de Baltazar \& Zuchetti [101]

Figura 32 - Mapa geológico simplificado da mina Cuiabá, no nível 3, mostrando as diferentes distribuições de rocha encontradas por

Lobato et al. [102]

Figura 33 - Coluna estratigráfica simplificada da mina Cuiabá por

Trópia [104]

Figura 34 - Ajuste do sistema de suporte aplicado na rampa do Serrotinho por Costa et al. [106]: (a) suporte danificado com as grande deformações rochosas e (b) sistema ajustado com concreto projetado e tela soldada.

Figura 35 - Evolução da resistência à compressão do concreto projetado

Figura 36 - Evolução do da resistência à compressão do concreto projetado nas primeiras idades

Figura 37 - Distribuição granulométrica compreendida entre os limites 
estabelecidos pela EFNARC [19] 76

Figura 38 - Procedimento de mistura realizado em laboratório 78

Figura 39 - Processo de mistura na mina Cuiabá: (a) central de concreto dentro da mina Cuiabá. (b) caminhão betoneira. 79

Figura 40 - Robô de projeção usado para a moldagem das amostras $\quad 79$

$\begin{array}{ll}\text { Figura } 41 \text { - Fibras de aço e sintéticas estudadas } & 81\end{array}$

Figura 42 - Moldes de PVC em base de acrílico usados para a moldagem das amostras para o ensaio de arrancamento $\quad 85$

Figura 43 - Formas usadas para moldagem dos painéis circulares $\quad 85$

Figura 44 - Forma de madeira usada para a moldagem do painel de larga escala $\quad 85$

Figura 45 - Configuração do ensaio de arrancamento $\quad 87$

Figura 46 - Desenho esquemático do ensaio de arrancamento 87

Figura 47 - Desenho esquemático do ensaio de flexão baseado na norma EN 14651 [54]. Dimensões em mm. 88

Figura 48 - Ensaio de flexão em três pontos (EN 14651) 89

Figura 49 - Detalhe do clip gauge na face inferior do prisma 90

Figura 50 - Desenho esquemático do ensaio de flexão em painel circular:

(a) disposição dos apoios no painel e (b) ilustração do ensaio e posicionamento do LVDT. Dimensões em mm. 91

Figura 51 - Detalhe do painel circular na máquina de ensaios 91

Figura 52 - Desenho esquemático do ensaio de flexão em painel quadrado:

(a) disposição do arranjo experimental do painel e (b) ilustração do ensaio e posicionamento do LVDT. Dimensões em mm. 92

Figura 53 - Detalhe do painel quadrado na máquina de ensaios 93

Figura 54 - Ensaio de painel de larga escala $\quad 94$

Figura 55 - Desenho esquemático do ensaio de flexão em painel de larga escala: (a) disposição do setup do painel e (b) ilustração do ensaio e posicionamento do LVDT. Dimensões em mm.

Figura 56 - Resultados dos ensaios de flexão em três pontos de acordo com a norma EN 14651 [54] para o concreto reforçado com dois tipos de fibra polimérica em diferentes frações volumétricas: (a) TamFib SP54 (PPF1) e (b) BarChip54 (PPF2) 96 
Figura 57 - Resultados dos ensaios de flexão em três pontos de acordo com a norma EN 14651 [54] para o concreto reforçado com as fibras poliméricas TamFib SP54 (PPF1) e BarChip54 (PPF2) divididos nas frações volumétricas analisadas: (a) $4.2 \mathrm{~kg} / \mathrm{m}^{3}$, (b) $6 \mathrm{~kg} / \mathrm{m}^{3}$ e (c) $8 \mathrm{~kg} / \mathrm{m}^{3}$ Figura 58 - Resultados dos ensaios de flexão em três pontos de acordo com a norma EN 14651: (a) concreto reforçado com diferentes frações volumétricas de fibra de aço, (b) comparação entre a adição de $25 \mathrm{~kg} / \mathrm{m}^{3}$ de fibra de aço e adição da fibra de PPF1 e (c) comparação entre a adição de $25 \mathrm{~kg} / \mathrm{m}^{3}$ de fibra de aço e adição da fibra de PPF2 Figura 59 - Resultados dos ensaios de arrancamento: (a) comparação entre as fibras PPF1 e PPF2, (b) arrancamento das fibras SF e (c) curvas médias para as três fibras analisadas

Figura 60 - Resultados dos ensaios de flexão em painéis circulares (ASTM C1550 [49]) do concreto projetado com fibras. Amostras fabricadas na mina Cuiabá: (a) curvas de força por deslocamento e (b) tenacidade por deslocamento

Figura 61 - Dimensionamento do sistema de suporte da mina Cuiabá a partir da classificação modificada de Papworth [48].

Adaptado de Papworth [48]

Figura 62 - Resultados dos ensaios de flexão em painéis quadrados (EN 14488-5 [50]) e circulares (ASTM C1550 [49]) do concreto projetado reforçado com $4,2 \mathrm{~kg} / \mathrm{m}^{3}$ de fibra PPF1. Curvas de força e tenacidade por deslocamento para (a) ensaios de painel quadrado (EN 14488-5 [50]) e (b) comparação dos ensaios em painéis circulares e quadrados

Figura 63 - Curvas de força por deslocamento até $8 \mathrm{~mm}$ para o concreto projetado reforçado com 4,2 kg/m³ de PPF1 em ensaios de flexão em painéis (a) quadrados com apoio contínuo (EN 14488-5 [50]) e (b) circulares em três apoios rotulados (ASTM C1550 [49])

Figura 64 - Modo de ruptura dos ensaios de flexão em painéis (a) circulares em três apoios rotulados (ASTM C1550 [49]) e (b) quadrados com apoio contínuo (EN 14488-5 [50])

Figura 65 - Resultados do ensaio de flexão do painel de larga escala para o concreto reforçado com 4,2 kg/m³ de fibra PPF1: (a) curva de força 
e tenacidade e deslocamento e (b) curva de força por deslocamento até $30 \mathrm{~mm}$ de deslocamento

Figura 66 - Comparação do comportamento pós-fissuração do concreto reforçado com $4,2 \mathrm{~kg} / \mathrm{m}^{3}$ de fibra PPF1 através dos ensaios em painéis de larga escala e de acordo com a norma EN 14488-5

Figura 67 - Evolução da abertura de fissuras em (a) com $20 \mathrm{~mm}$ de deslocamento e (b) $70 \mathrm{~mm}$ de deslocamento. Os números I e II são correspondentes às linhas tracejadas na Figura 65(a)

Figura 68 - Modo de fissuração do painel após $95 \mathrm{~mm}$ de deslocamento:

(a) visão inferior e (b) superior das fissuras. Estado correspondente ao número III indicado na linha tracejada da Figura 65(a)

Figura 69 - Extração do corpos de prova com sistema de perfuração diamantado: (a) extração de prismas moldados no laboratório e (b) corte dos cilindros mantendo a relação diâmetro/altura igual a um

Figura 70 - Ensaio de duplo puncionamento na MTS815/315.02

Figura 71 - Ensaio de duplo puncionamento sendo executado nas seguintes máquinas de ensaio universal: (a) MTS810/318.25 e (b) MTS311.32

Figura 72 - Ensaio de duplo puncionamento sendo executado nas seguintes máquinas de ensaio universal: (a) MTS815/315.02 e (b) INSTRON5582 Figura 73 - Máquinas de ensaio utilizadas para a análise do ensaio de duplo puncionamento: (a) MTS810/318.25, (b) MTS311.32, (c) MTS815/315.02 e (d) INSTRON5582

Figura 74 - Curvas de força por TCOD obtidas do ensaio de duplo puncionamento realizado em diferentes máquinas de ensaio universal para o concreto reforçado com (a) $4,2 \mathrm{~kg} / \mathrm{m}^{3} \mathrm{de} P P F 1$ e

(b) $25 \mathrm{~kg} / \mathrm{m}^{3}$ de SF

Figura 75 - Variação da instabilidade pós-pico de acordo com o aumento da rigidez da máquinas de ensaio universal estudadas no caso do concreto reforçado com (a) $4,2 \mathrm{~kg} / \mathrm{m}^{3}$ de PPF1 e (b) $25 \mathrm{~kg} / \mathrm{m}^{3}$ de SF Figura 76 - Variação da tenacidade em 4 mm de $T C O D\left(\mathrm{E}_{\mathrm{BCN}, 4.0}\right) \mathrm{com}$ o aumento da rigidez da máquinas de ensaio universal estudadas no caso do concreto reforçado com (a) $4,2 \mathrm{~kg} / \mathrm{m}^{3}$ de PPF1 e (b) $25 \mathrm{~kg} / \mathrm{m}^{3}$ de SF 
Figura 77 - Variação da força residual para os diferentes tipos de máquinas de ensaio universal estudadas no caso do concreto reforçado com

(a) $4,2 \mathrm{~kg} / \mathrm{m}^{3}$ de PPF1 e (b) $25 \mathrm{~kg} / \mathrm{m}^{3}$ de SF

Figura 78 - Desenho esquemático da falha do prima submetido a um

ensaio de flexão em três pontos e de sua abertura de fissura

Figura 79 - Modo de fissuração do ensaio de duplo puncionamento: (a)

fotografia e (b) desenho esquemático

Figura 80 - Correlação entre as tenacidade obtidas a partir dos ensaios de flexão em três pontos $\left(\mathrm{T}_{\mathrm{EN}}\right)$ e de duplo puncionamento $\left(\mathrm{E}_{\mathrm{BCN}}\right)$ : (a) C4.2PPF1 e (b) C25SF

Figura 81 - Variação do erro entre a tenacidade obtida no ensaio de flexão em três pontos $\left(\mathrm{T}_{\mathrm{EN}}\right)$ e a partir das correlações com o ensaio de duplo puncionamento $\left(\mathrm{T}_{\mathrm{EN}}\left(\mathrm{E}_{\mathrm{BCN}}(T C O D)\right)\right)$ para as diferentes máquinas estudadas. Resultados obtidos para a adição de $4,2 \mathrm{~kg} / \mathrm{m}^{3}$ de PPF1 e $25 \mathrm{~kg} / \mathrm{m}^{3}$ de SF Figura 82 - Correlação para tensões residuais entre os ensaios de duplo puncionamento $\left(f_{c t, R x}\right)$ e flexão em três pontos $\left(F_{R, j}\right)$ : (a) C4.2PPF2 e (b) $\mathrm{C} 25 \mathrm{SF}$

Figura 83 - Variação do erro entre a tensão residual obtida no ensaio de flexão em três pontos $\left(\mathrm{F}_{\mathrm{R}, \mathrm{j}}\right)$ e a partir das correlações com o ensaio de duplo puncionamento $\left(\mathrm{F}_{\mathrm{R}, \mathrm{j}}\left(\mathrm{f}_{\mathrm{ct}, \mathrm{Rx}}(T C O D)\right)\right)$ para as diferentes máquinas estudadas. Resultados obtidos para a adição de (a) $4,2 \mathrm{~kg} / \mathrm{m}^{3}$ de PPF1 e (b) $25 \mathrm{~kg} / \mathrm{m}^{3}$ de SF

Figura 84 - Comportamento mecânico do concreto reforçado com $4,2 \mathrm{~kg} / \mathrm{m}^{3}$ de PPF1 quando submetido ao ensaio de duplo puncionamento com controles fechados de deslocamento do atuador e externo pela corrente extensométrica: (a) diferentes controles na MTS810/815.25, (b) diferentes controles na MTS311.32 e (c) comparação entre as duas máquinas para o controle pela corrente extensométrica

Figura 85 - Comportamento mecânico do concreto reforçado com $25 \mathrm{~kg} / \mathrm{m}^{3}$ de SF quando submetido ao ensaio de duplo puncionamento com controles fechados de deslocamento do atuador e externo pela corrente extensométrica: (a) diferentes controles na MTS810/815.25, (b) diferentes controles na MTS311.32 e (c) comparação entre as duas máquinas para o 
controle pela corrente extensométrica

Figura 86 - Comportamento mecânico do concreto reforçado com

25,40 e $60 \mathrm{~kg} / \mathrm{m}^{3}$ de SF quando submetido ao ensaio de duplo

puncionamento na MTS311.32 com controles fechados (a) pela corrente extensométrica e (b) pelo deslocamento do atuador

Figura 87 - Pórtico modelo: (a) detalhe das dimensões da base, das colunas e do travessão do pórtico e (b) modelo teórico para cálculo da rigidez 


\section{Lista de tabelas}

Tabela 1 - Dosagem básica para concreto projetado por Jolin \& Beaupre [29] 40

Tabela 2 - Propriedades típicas de fibras usadas como reforço

Tabela 3 - Recomendação de dimensionamento de suporte de acordo com a classificação RMR [42]

Tabela 4 - Classificação do maciço rochoso a partir do sistema Q

(Barton et al. [43])

Tabela 5 - Correlação entre a qualidade do maciço rochoso do sistema Q

e a tenacidade obtida dos ensaios de painel (Papworth [48])

Tabela 6 - Resultados publicados de tenacidade para diferentes fibras

sintéticas e aço através dos ensaios de flexão em painel circular

(ASTM C1550 [49])

Tabela 7 - Classificação do maciço rochoso nos corpos

Fonte Grande Sul e Serrotinho da mina Cuiabá.

Adaptado de Barbosa [97]

Tabela 8 - Traço original usado para a produção de amostras na mina Cuiabá 77

Tabela 9 - Traço adaptado usado para a produção de amostras no laboratório 77

Tabela 10 - Características das fibras sintéticas de acordo com seus

respectivos fabricantes

Tabela 11 - Características das fibras de aço de acordo com seu fabricante

Tabela 12 - Programa experimental para a análise do comportamento

mecânico do concreto com fibras para revestimento de túneis

Tabela 13 - Resumo dos parâmetros obtidos dos ensaios de flexão em três pontos de acordo com a norma EN 14651 [54]. Desvio padrão indicado entre parênteses

Tabela 14 - Resultados de carga e tensão de aderência máximas do ensaio de arrancamento. Desvio padrão indicado entre parênteses

Tabela 15 - Resultados de tenacidade, carga última e classificação de índice de tenacidade para o concreto reforçado com as diferentes frações de fibra de aço e sintética analisadas após o ensaios de flexão em painel circular (ASTM C1550 [49]). O índice $-P$ indica as amostras de 
concreto projetado com fibras que foram fabricadas na mina Cuiabá. Desvio padrão indicado entre parênteses

Tabela 16 - Classificação de cada região indicada na Figura 61.

Adaptado de Grimstad \& Barton [38]

Tabela 17 - Resultados de tenacidade e carga última dos ensaios de flexão em painéis quadrados (EN 14488-5 [50]) e circulares (ASTM C1550 [49]).

Desvio padrão indicado entre parênteses

Tabela 18 - Classificação do concreto reforçado com fibras de acordo com a qualidade do maciço rochoso a partir do trabalho de Papworth [48].

Tenacidade obtida a partir de ensaios de flexão em painéis de acordo com as normas EN 14488-5 e ASTM C1550

Tabela 19 - Valores de força $\left(\mathrm{P}_{\mathrm{f}, 1}, \mathrm{P}_{\mathrm{f}, 2}\right.$ e $\left.\mathrm{P}_{\mathrm{f}, 3}\right)$ de acordo com os

deslocamentos $\left(\delta_{\mathrm{f}, 1}, \delta_{\mathrm{f}, 2}\right.$, e $\left.\delta_{\mathrm{f}, 3}\right)$ ao longo do ensaio de flexão do painel de larga escala

Tabela 20 - Resultados de força e tenacidade para diferentes níveis de deslocamento ao longo do ensaio de flexão do painel de larga escala

Tabela 21 - Programa experimental realizado a fim de estudar o controle de qualidade do concreto com fibras

Tabela 22 - Configuração I: ensaios de duplo puncionamento realizados com controle fechado de deslocamento do atuador

Tabela 23 - Configuração II: ensaio de duplo puncionamento realizado com controle fechado pela corrente extensométrica

Tabela 24 -Especificações das máquinas de ensaio universal de acordo com os fabricantes

Tabela 25 - Resultados médios de instabilidade pós-pico média obtidos a partir do ensaio de duplo puncionamento realizado em diferentes máquinas de ensaio universal para o concreto reforçado com 4,2 kg/m³ de PPF1 e $25 \mathrm{~kg} / \mathrm{m}^{3}$ de SF. Desvio padrão entre parênteses Tabela 26 - Resultados médios de tenacidade em $4 \mathrm{~mm}$ de TCOD $\left(\mathrm{E}_{\mathrm{BCN}, 4.0}\right)$ obtidos a partir do ensaio de duplo puncionamento realizado em diferentes máquinas de ensaio universal para o concreto reforçado com 4,2 kg/m³ de PPF1 e $25 \mathrm{~kg} / \mathrm{m}^{3}$ de SF. Desvio padrão entre parênteses 
Tabela 27 - Resultados médios de força residual $\left(\mathrm{P}_{\mathrm{R}, \mathrm{x}}\right)$ para diferentes níveis de TCOD obtidos a partir do ensaio de duplo puncionamento realizado em diferentes máquinas de ensaio universal para o concreto reforçado com 4,2 kg/m² de PPF1 e $25 \mathrm{~kg} / \mathrm{m}^{3}$ de SF.

Desvio padrão entre parênteses

Tabela 28 - Equivalências entre os valores de $C M O D, T C O D$ e abertura de fissuras média $(w)$

Tabela 29 - Resultados de tenacidade obtidos a partir do ensaio de flexão em três pontos. Desvio padrão entre parênteses

Tabela 30 - Resultados de tenacidade obtidos a partir do ensaio de duplo puncionamento. Desvio padrão entre parênteses

Tabela 31 - Parâmetros de correlação entre $\mathrm{T}_{\mathrm{EN}}$ e $\mathrm{E}_{\mathrm{BCN}}$ para o concreto reforçado com fibras nas diferentes máquinas de ensaio e metodologias de controle

Tabela 32 - Valores de tenacidade estimados a partir das correlações entre os ensaios de flexão em três pontos e duplo puncionamento em diferentes níveis de TCOD. Resultados obtidos para a adição de $4,2 \mathrm{~kg} / \mathrm{m}^{3}$ de PPF1 e $25 \mathrm{~kg} / \mathrm{m}^{3}$ de SF

Tabela 33 - Resultados de tensão residual obtidos a partir do ensaio de flexão em três pontos. Desvio padrão entre parênteses

Tabela 34 - Resultados de tensão residual obtidos a partir do ensaio de duplo puncionamento. Desvio padrão entre parênteses

Tabela 35 - Parâmetros de correlação entre $f_{c t, R x}$ e $F_{R, j}$ para o concreto reforçado com fibras nas diferentes máquinas de ensaio e metodologias de controle

Tabela 36 - Valores de tensão residual estimados a partir das correlações entre os ensaios de flexão em três pontos e duplo puncionamento para cada máquina de ensaios estudadas. Resultados obtidos para a adição de $4,2 \mathrm{~kg} / \mathrm{m}^{3}$ de PPF1 e $25 \mathrm{~kg} / \mathrm{m}^{3}$ de SF

Tabela 37 - Resultados de tenacidade e resistência residual para o ensaio de duplo puncionamento submetido aos controles fechados de deslocamento pelo atuador e externo pela corrente extensométrica. Resultados obtidos para a adição de $4,2 \mathrm{~kg} / \mathrm{m}^{3}$ de PPF1 e $25 \mathrm{~kg} / \mathrm{m}^{3}$ de SF. 
Desvio padrão entre parênteses

Tabela 38 - Resultados de resistência de residual e tenacidade

para o concreto com 25, 40 e $60 \mathrm{~kg} / \mathrm{m}^{3}$ de fibras SF do ensaio de duplo

puncionamento com controles de deslocamento do atuador e externo pela

corrente extensométrica. Todos os ensaios foram realizados na

MTS311.32. Desvio padrão entre parênteses

Tabela 39 - Memória de cálculo para estimar a rigidez da MTS810/318.25 158 


\section{Introdução}

1.1.

Panorama Geral

Nos últimos anos a indústria da mineração se tornou uma das principais usuárias de concreto projetado com fibras como sistema de suporte em obras de escavação subterrânea. $\mathrm{O}$ trabalho simultâneo de múltiplas áreas da engenharia, o difícil acesso às escavações e os carregamentos complexos são alguns dos principais desafios associados à mineração subterrânea e demandam cada vez mais tecnologias inovadoras na aplicação do concreto projetado.

O concreto projetado é especialmente elaborado com base nas recomendações vigentes e projetado pneumaticamente em altas velocidades nas superfícies expostas em obras de escavação subterrânea a fim de garantir o suporte do maciço rochoso. Quando as condições do terreno subterrâneo são muito pobres e a rocha muito fraca, como em muitas obras de escavação no Brasil, o sistema de suporte precisa ser corretamente dimensionado, já que, historicamente, uma das principais causas de acidentes e fatalidades em obras de escavação subterrânea são as quedas de blocos de rocha. Mais pesquisas, portanto, precisam ser desenvolvidas no dimensionamento e no controle tecnológico dos sistemas de suporte, a fim de proteger os trabalhadores no campo de trabalho em minas subterrâneas.

Pensando em conter as deformações rochosas com a aplicação de concreto projetado, fibras são adicionadas à mistura visando uma maior capacidade de deformações do material. A presença desse reforço no concreto cria pontes por entre as fissuras e controla sua propagação. Como consequência, a adição de fibras acarreta em um incremento na tenacidade e nas tensões residuais de tração e flexão do material compósito.

Dessa maneira, com a evolução da aplicação do concreto projetado com fibras, um maior número de tipos de fibra vem sendo oferecido no mercado com uma gama enorme de formas e fabricados a partir de materiais distintos. As fibras também podem ser usadas na forma de tecidos, porém, devido à natureza da 
aplicação do concreto projetado e por razões econômicas, as fibras discretas lançadas aleatoriamente na matriz cimentícia são o principal produto do momento. As fibras mais usadas como reforço nas aplicações de mineração são as fibras de polipropileno e aço.

Inicialmente, as fibras sintéticas eram recomendadas somente para controle de propagação de fissuras, porém, já é possível encontrar diversos fabricantes oferecendo fibras de polipropileno de diferentes comprimentos e propriedades visando sua aplicação para concreto projetado. Com esse crescimento de vendas, as novas fibras sintéticas vêm ganhando espaço no mercado com a fama de garantir a mesma capacidade de resistência pós-pico e tenacidade das fibras de aço. Dessa maneira, destaca-se a necessidade de realização de ensaios mecânicos com o objetivo de melhor entender a capacidade de absorção de energia do material antes de sua aplicação em definitivo nas obras de escavação.

A crescente demanda por suporte técnico e tecnológico da área de mineração, por outro lado, entra em conflito com a falta de maturidade do meio técnico e a ausência de normas específicas no Brasil. Dessa maneira, tem sido realizado um grande esforço do meio acadêmico para analisar o comportamento mecânico do concreto com fibras visando seu dimensionamento para as obras de escavação subterrâneas e seu controle tecnológico.

\section{2. \\ Objetivos}

O presente trabalho apresenta dois objetivos gerais. O primeiro é estudar o comportamento mecânico e o dimensionamento do concreto projetado com fibras para o revestimento dos túneis da mina Cuiabá. Já o segundo visa desenvolver o controle tecnológico do concreto com fibras através do ensaio de duplo puncionamento (ensaio de Barcelona).

Entre os objetivos específicos, inclui-se a caracterização e classificação do concreto projetado com fibras de aço e sintéticas para revestimento de túneis de acordo com o grau de deformação das rochas após a escavação. Duas fibras sintéticas de diferentes fabricantes e propriedades materiais foram analisadas nesse trabalho. A caracterização dos compósitos e da interface fibra-matriz foram analisadas através de ensaios de flexão em prismas e ensaios de arrancamento, 
respectivamente. O dimensionamento do suporte com concreto projetado foi avaliado através de ensaios de flexão em painéis circulares e quadrados. Além disso, executou-se ensaio de flexão em maior escala com o objetivo de estudar o comportamento mecânico do sistema de suporte mais próximo da escala real das aplicações em obras de mineração.

Com relação ao estudo do controle tecnológico, avaliou-se a resposta do ensaio de duplo puncionamento quando controlado pelo deslocamento vertical do atuador hidráulico e externamente pela corrente extensométrica. A instabilidade pós-pico também foi analisada considerando diferentes tipos de máquinas de ensaio universal (eletromecânica e servo-hidráulica) e diferentes rigidezes do pórtico de suporte do atuador. Por fim, avaliou-se a influência da instabilidade pós-fissuração nas correlações entre os ensaios de flexão em três pontos (EN 14651) e duplo puncionamento.

\section{3.}

\section{Estrutura da Dissertação}

Essa dissertação de mestrado está organizada em oito capítulos, conforme apresentado na Figura 1.

\begin{tabular}{|c|}
\hline $\begin{array}{l}\text { Capítulo } 1 \\
\text { Introdução }\end{array}$ \\
\hline $\begin{array}{c}\text { Capítulo } 2 \\
\text { Revisão bibliográfica }\end{array}$ \\
\hline $\begin{array}{l}\text { Capítulo } 3 \\
\text { Escavação na mina Cuiabá }\end{array}$ \\
\hline $\begin{array}{l}\text { Capítulo } 4 \\
\text { Caracterização dos materiais }\end{array}$ \\
\hline $\begin{array}{c}\text { Capítulo } 5 \\
\text { Comportamento mecânico do concreto projetado com fibras para revestimento dos túneis da mina Cuiabá }\end{array}$ \\
\hline $\begin{array}{c}\text { Capítulo } 6 \\
\text { Controle de qualidade do concreto com fibras através do ensaio de duplo puncionamento }\end{array}$ \\
\hline $\begin{array}{l}\text { Capítulo } 7 \\
\text { Conclusão }\end{array}$ \\
\hline $\begin{array}{c}\text { Capítulo } 8 \\
\text { Referências bibliográficas }\end{array}$ \\
\hline
\end{tabular}

Figura 1 - Estrutura da dissertação de mestrado

O Capítulo 1 apresenta a contextualização e as motivações para a realização desse trabalho, além dos objetivos e a estrutura da dissertação. 
Em seguida, o Capítulo 2 traz a revisão bibliográfica, que aborda a utilização do concreto projetado com fibras em revestimento de túneis, com ênfase no comportamento mecânico e no controle de qualidade do compósito em construção de túneis subterrâneos. São destacados trabalhos relacionados ao desempenho mecânico e ao dimensionamento do concreto projetado com fibras de aço e polipropileno, além do desenvolvimento do ensaio de duplo puncionamento como alternativa para o controle de tecnológico do concreto com fibras em obras de mineração.

Já no Capítulo 3, é discutida a caracterização geológica e geotécnica do maciço rochoso presente na mina Cuiabá, assim como a classificação do maciço rochoso de acordo com as referências bibliográficas. Além disso, são apresentados os sistemas de suporte usados após a escavação e o controle tecnológico aplicados atualmente na mina.

O Capítulo 4 apresenta a caracterização dos materiais usados na pesquisa como a granulometria do agregado analisado e as propriedades das fibras estudadas de acordo com as informações fornecidas pelo fabricante. Nessa seção também é apresentado o procedimento de mistura adotado durante o programa experimental e as informações do traço aplicado.

O Capítulo 5 aborda inicialmente a caracterização do concreto reforçado com fibras através de ensaios de flexão em prismas (EN 14651) e ensaios de arrancamento para as fibras de aço e polipropileno analisadas. Em seguida, discutem-se os resultados obtidos em ensaios de flexão em painéis circulares e quadrados visando o dimensionamento do concreto projetado com fibras para o revestimento dos túneis da mina Cuiabá. Por fim, estuda-se o comportamento mecânico do material quando submetido a ensaios de flexão em painéis de larga escala.

Por sua vez, o Capítulo 6 trata do controle tecnológico do concreto com fibras através do ensaio de duplo puncionamento (ensaio de Barcelona). Primeiro, avaliou-se a instabilidade pós-pico do ensaio de Barcelona quando submetido a diferentes máquinas de ensaio universal com diferentes rigidezes e diferentes tipos de operação (eletromecânica e servo-hidráulica). Em seguida, estudou-se a influência dessa instabilidade pós-fissuração na correlação entre os ensaios de flexão em três pontos e duplo puncionamento. A campanha experimental se encerra 
com a análise do ensaio de tração indireta quando controlado externamente pela corrente extensométrica ou pelo deslocamento do atuador.

O Capítulo 7 traz a conclusão final do trabalho com suas as principais contribuições para o estudo do comportamento mecânico do concreto projetado com fibras e seu controle de qualidade, além de algumas sugestões para futuros trabalho na área.

O Capítulo 8 apresenta as referências bibliográficas. 


\section{2 \\ Revisão bibliográfica}

2.1.

Sistema de suporte e reforço

\subsection{1.}

Terminologia

O termo suporte é normalmente usado para descrever os procedimentos e materiais usados para aumentar a estabilidade e manter a capacidade de suporte de carga da rocha após a escavação. De acordo com as práticas modernas aplicadas atualmente, porém, foi estabelecido uma distinção entre suporte e reforço, baseado nas definições introduzidas por Windsor [1]. Suporte é a aplicação de forças de reação em uma superfície de escavação e inclui técnicas e dispositivos como concreto projetado, telas e revestimentos de aço ou concreto. Reforço, por outro lado, está associado com a conservação ou melhora das propriedades do maciço rochoso através da aplicação de tirantes ou escoras de aço [1].

Os suportes e reforços rochosos de escavações permanente também podem ser classificados como primários ou secundários. Reforço ou suporte são considerados primários caso eles sejam aplicados imediatamente após a escavação a fim de garantir a segurança do trabalho no local durante as escavações subsequentes e para iniciar o processo de mobilização e conservação da rocha através do controle de suas deformações [2]. O sistema primário pode formar parcial ou completamente todo o suporte ou reforço aplicado. Qualquer sistema aplicado em um estágio mais avançado da construção é considerado secundário [2].

Brady \& Brown [2] também destacam que os sistemas utilizados podem classificados como ativos ou passivos. No primeiro caso, aplica-se uma força prédeterminada sobre a superfície da rocha escavada no momento de sua instalação, como no caso de tirantes tensionado. Os sistemas passivos, por sua vez, não são instalados com uma carga aplicada, mas desenvolvem sua carga ao longo da deformação da rocha, como no caso da aplicação do concreto projetado com fibras. 
Para Hudson \& Harrison [3], os princípios de reforço e suporte de rocha podem ser resumidos de acordo com a Figura 2.

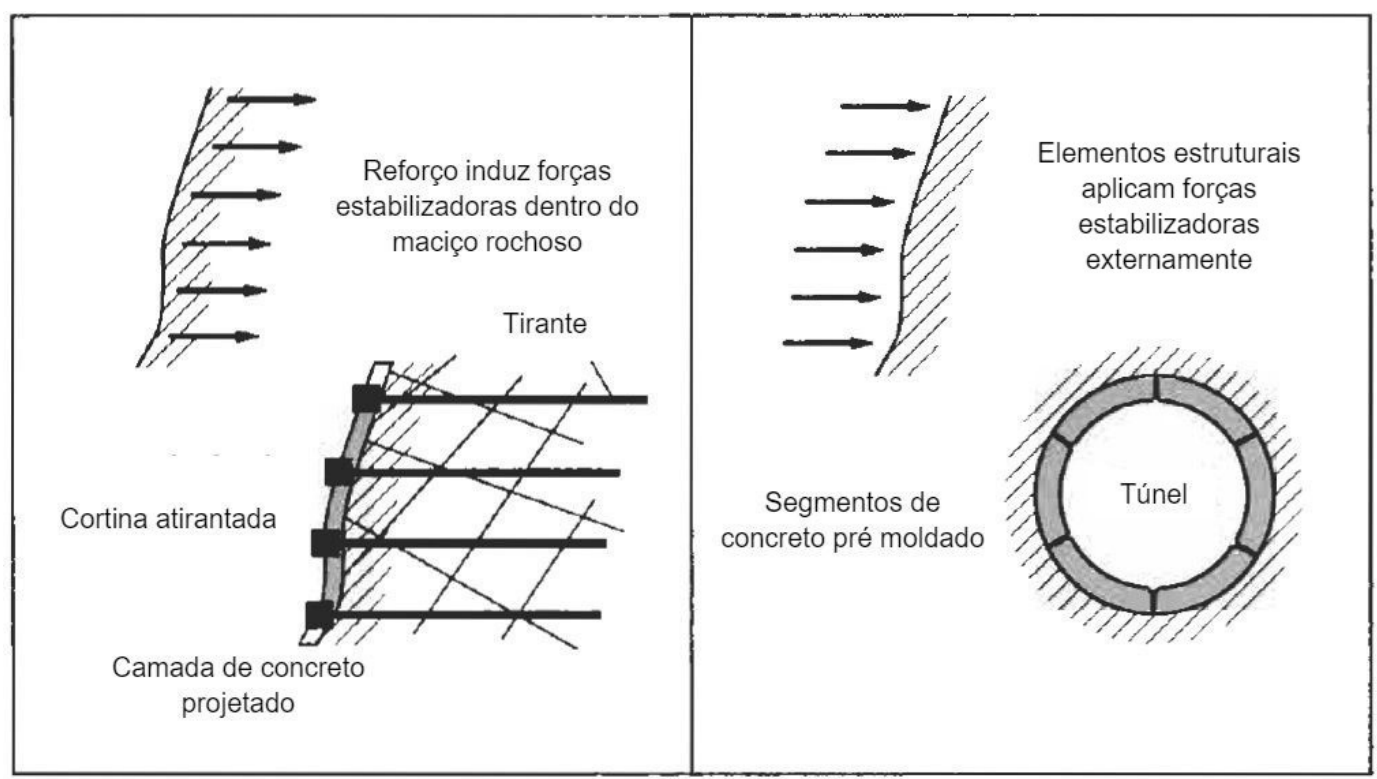

(a)

(b)

Figura 2 - Princípios de (a) reforço e (b) suporte de rocha. Adaptado de Hudson \& Harrison [3]

\subsection{2.}

\section{Princípios de atuação}

A Figura 3 ilustra o princípio de atuação do suporte ou reforço a cada avanço da escavação, considerando um estado de tensão hidrostático com magnitude $p_{0}$. É possível observar a evolução da deformação e da pressão radial da escavação e do sistema de suporte ou reforço na seção $\mathrm{X}-\mathrm{X}$ ao longo do avanço das escavações além da seção X-X. A discussão completa dos princípios de atuação dos sistemas de suporte e reforço pode ser analisada em Brady \& Brown [2].

$\mathrm{Na}$ fase 1 , a escavação ainda não atingiu a seção $\mathrm{X}-\mathrm{X}$ e o maciço rochoso encontra-se em equilíbrio com a pressão atuante no suporte, $p_{i}$, atuando de forma igual e oposta a $p_{0}$.

$\mathrm{Na}$ fase 2, a escavação avança além da seção X-X, permitindo que a rocha se deforme na seção estudada. As pressões correspondentes aos pontos B e C atuam, respectivamente, no teto e na parede após esse avanço. Em seguida, na fase 3, é instalado o suporte com o objetivo de conter essas deformações 
Na etapa 4, onde constata-se um novo avanço do túnel, uma nova deformação da rocha ocorre na seção X-X, como indicado nas curvas CEG e BFH na Figura 3. A nova movimentação da rocha induz uma deformação no sistema de suporte, que é assumida como linear no exemplo e pode ser visualizada através da reta DEF, reagindo de forma passiva com a pressão do suporte nos pontos F e E. A partir desse ponto em diante, caso o suporte tenha sido corretamente dimensionado, a deformação da rocha será controlada pelo suporte, como indicado na etapa 5.

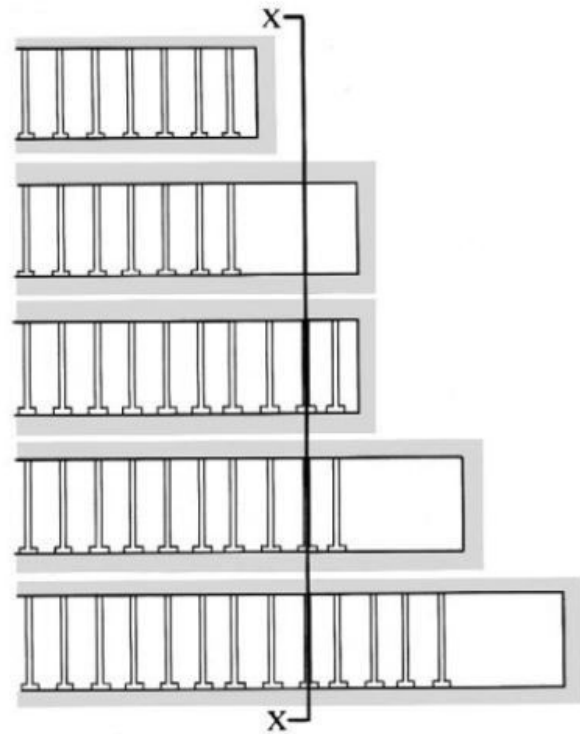

(a)
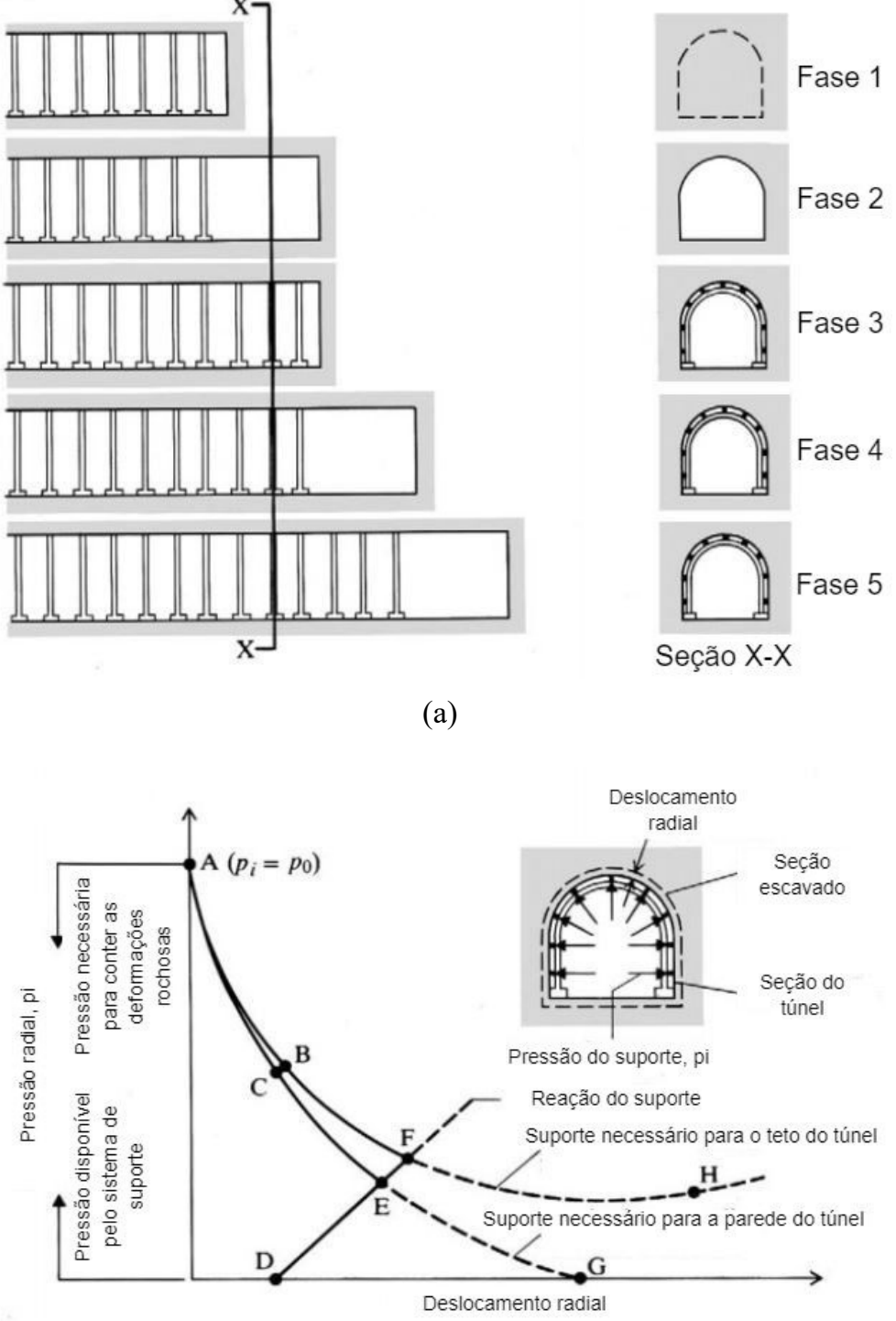

(b)

Figura 3 - Princípio de atuação de suporte ou reforço: (a) exemplo hipotético de avanço de escavação do túnel com instalação de sistema de suporte a cada ciclo de escavação e (b) Gráfico de pressão radial-deslocamento do maciço rochoso e do sistema de suporte. Adaptado de Brady \& 
A rigidez e o tempo de instalação do elemento de suporte apresentam uma importante influência no controle dos deslocamentos da rocha. A Figura 4 apresenta a interação entre rocha e sistema de suporte para um problema semelhante ao descrito na Figura 3. A curva $\mathrm{ABCDE}$ apresenta o comportamento da rocha analisada.

$\mathrm{O}$ suporte 1 foi instalado no ponto $\mathrm{F}$ e atinge o equilíbrio com o maciço rochoso no ponto B. Esse suporte apresenta alta rigidez e absorve grande parte da redistribuição de esforços, podendo atingir sua ruptura ao longo da escavação.

Os suportes 2 e 3, com menor rigidez, também foram instalados em $\mathrm{F}$ e atingem o equilíbrio nos pontos em $\mathrm{C}$ e $\mathrm{D}$, respectivamente. No caso do suporte 2 , há um alívio de parte das tensões, evitando grandes cargas sobre o sistema de reforço ou suporte. Para o caso da aplicação do suporte 3, o maciço já iniciou o processo de desprendimento de blocos por gravidade, podendo resultar na ruptura do sistema com a aplicação de qualquer carga extra [2].

O suporte 4 apresenta a mesma rigidez do suporte 2, porém, é instalado tardiamente. Nesse caso, pode ocorrer um acúmulo de convergência da escavação, resultando em uma sobrecarga no sistema de suporte antes de atingir o equilíbrio.

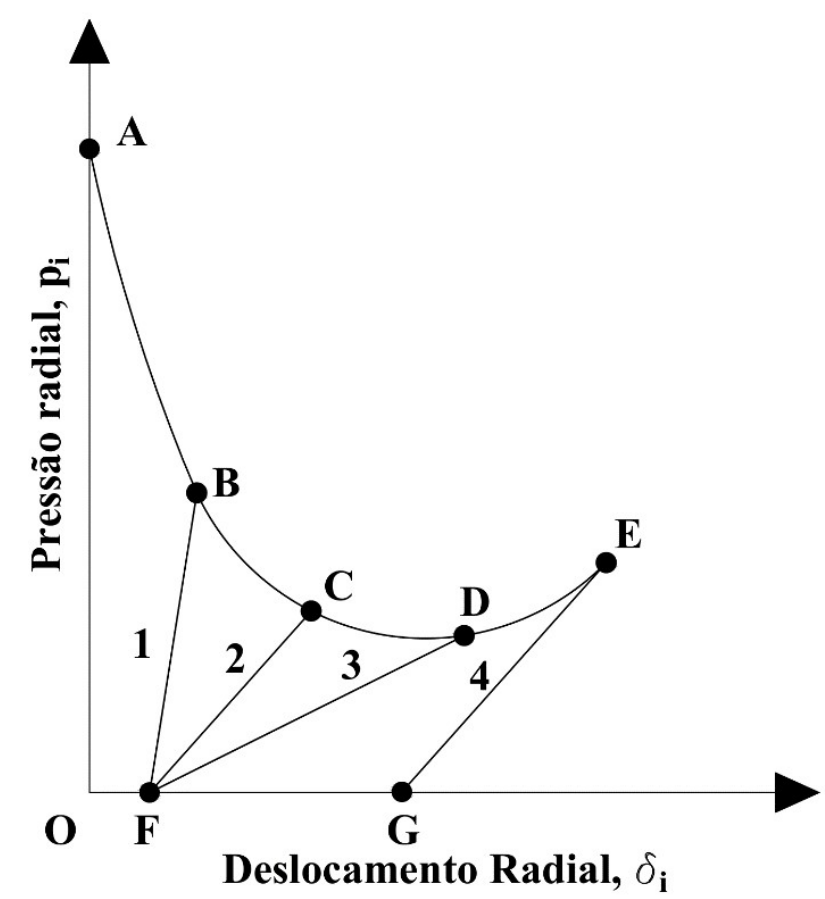

Figura 4 - Ilustração da influência da rigidez do suporte e do momento da instalação do sistema de suporte. Adaptado de Brady \& Brown [2] 
A Figura 5 ilustra alguns elementos de estabilização. Na prática, suportes e reforços, porém, apresentam usualmente rigidez não linear devido à má condição do contato entre rocha e os elementos de estabilização [2].

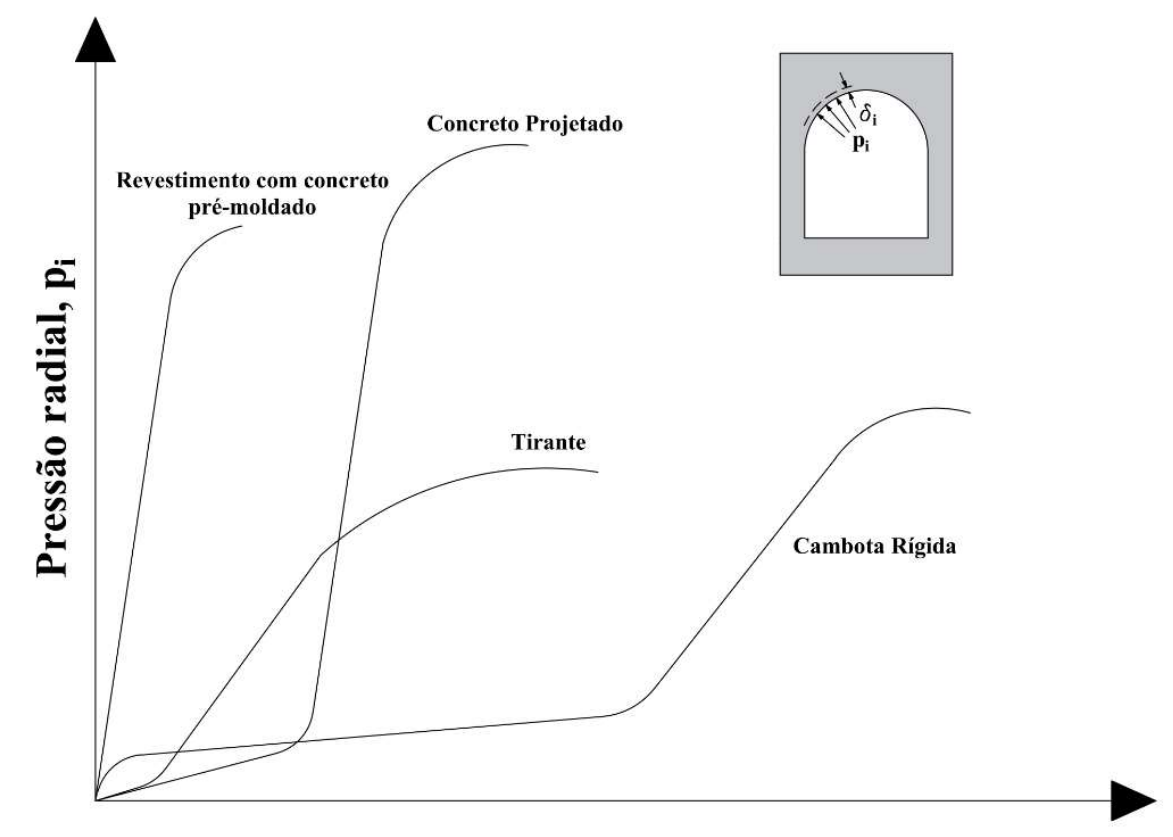

Deslocamento Radial, $\delta_{\mathbf{i}}$

Figura 5 - Curvas de reação de diferentes tipos de sistema de suporte. Adaptado de Brady \& Brown [2]

2.2.

Teoria do concreto projetado

\subsection{1.}

Mecanismos de atuação

Nas aplicações originais de escavação de túneis, o concreto projetado era dimensionado para funcionar como um arco compressivo, tirando proveito da alta resistência à compressão do concreto [4]. Os túneis eram, em geral, circulares, promovendo uma forte ação do arco feito com a aplicação do concreto, como mostrado na Figura 6.

Em obras de mineração, devido ao alto custo e à natureza de curto prazo da construção, a aplicação de concreto projetado difere consideravelmente das de obras de túnel. O piso, em geral, não recebe revestimento e o suporte não percorre toda a extensão das paredes, vide Figura 7. 


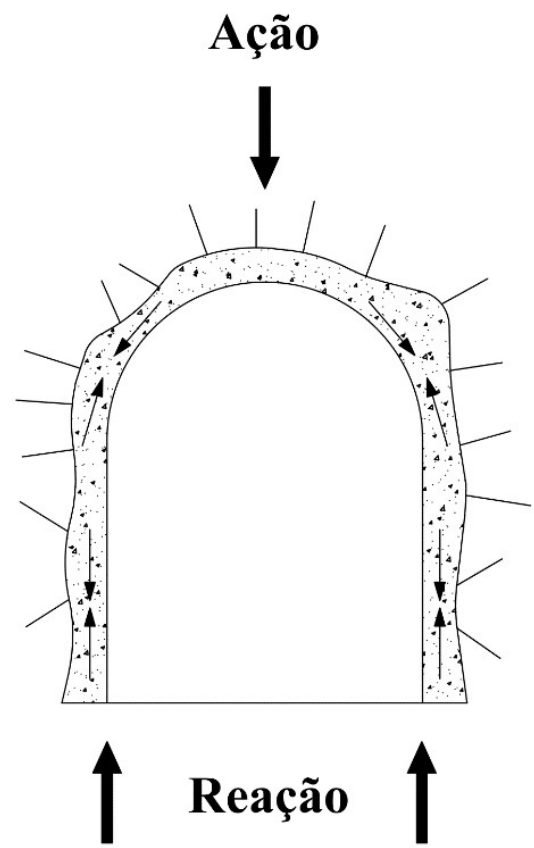

(a)

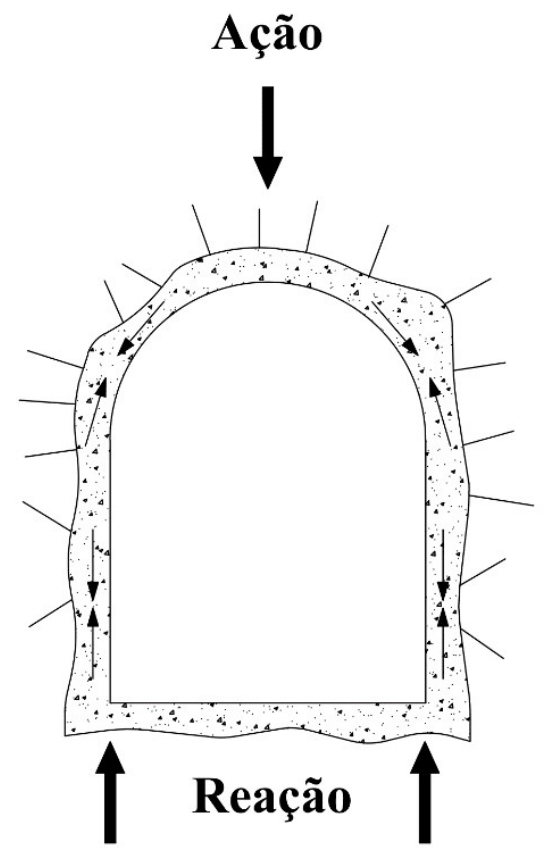

(b)

Figura 6 - Concreto projetado em compressão depois da aplicação até (a) piso e (b) por todo o túnel. Adaptado de Hadjigeorgiou \& Ptovin [4]

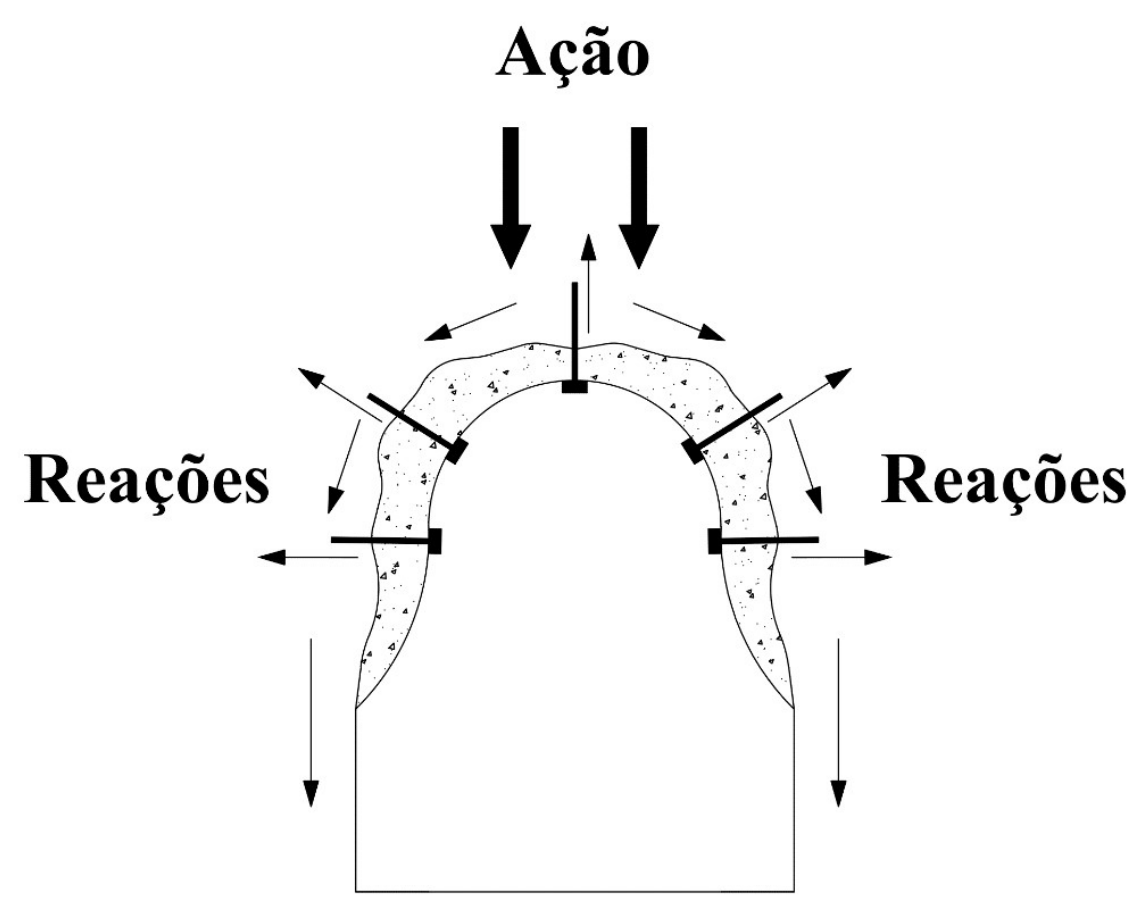

Figura 7 - Concreto projetado em compressão depois de sua aplicação que termina acima do piso do túnel como feito em obras de mineração. Adaptado de Hadjigeorgiou \& Ptovin [4] 
Dessa maneira, a resistência à compressão não exerce grande influência no dimensionamento do concreto projetado em obras de mineração. De acordo com Morton \& Villaescusa [5], o sistema de suporte instalado em obras de mineração está associado com os seguintes fatores:

- Aderência e/ou resistência ao cisalhamento na interação entre o concreto projetado e o maciço rochoso;

- Resistência à flexão;

- Transferência de carga do sistema de suporte para o sistema de reforço.

Stacey [6] descreve os diversos tipos mecanismos de atuação do concreto projetado. Esses mecanismos podem atuar individualmente ou em combinação:

a) Engrenamento dos blocos de rocha

A reação imediata gerada devido à aderência entre o revestimento e a rocha promove um engrenamento dos blocos e previne a queda do maciço rochoso [6]. O engrenamento dos blocos pode ser subdividido em uma série de outros mecanismos menores, explicados a seguir [6]:

- Engrenamento devido à aderência do concreto projetado com a rocha e à resistência à tração do concreto. A resistência ao cisalhamento na interface restringe o movimento dos blocos de rocha (Figura 8a);

- Desenvolvimento de uma resistência ao cisalhamento na interface do concreto projetado e a rocha em casos de pouca aderência do concreto (Figura (8(b));

- Penetração do concreto projetado entre as juntas e fissuras da rocha, inibindo sua queda (Figura 8(c));

- Aplicação de uma fina camada de revestimento para conter as tensões induzidas por spalling;

- Aplicação de uma camada espessa de concreto projetado (Figura 8(d)). A resistência ao cisalhamento do concreto projetado previne maiores falhas;

- Aplicação de uma camada fina de concreto projetado (Figura 8(e)). Com a baixa aderência do concreto na rocha, os blocos têm seu movimento contido devido à resistência à tração na flexão do suporte. 


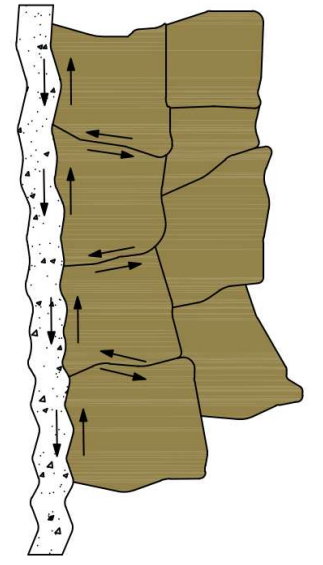

(a)

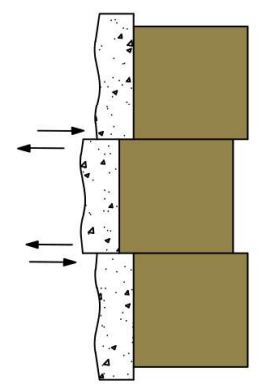

(d)

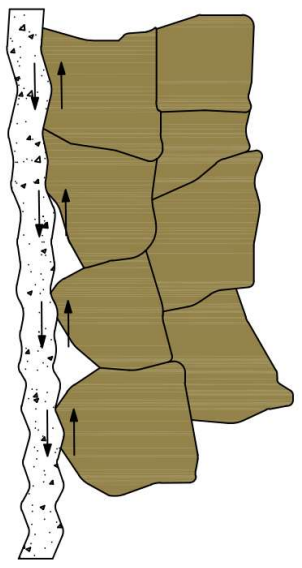

(b)

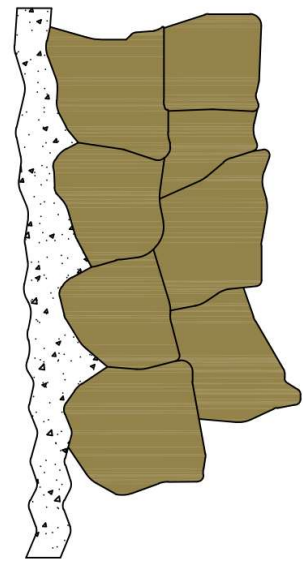

(c)
Resistência ao cisalhamento de uma cada espessa de concreto

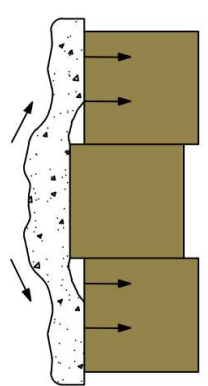

(e)
Tração no concreto e perda de aderência na interface

Figura 8 - Ilustração do mecanismo de engrenamento dos blocos de rocha: (a) engrenamento devido à aderência, (b) desenvolvimento de resistência ao cisalhamento com pouca aderência do concreto, (c) penetração do concreto entre as juntas da rocha, (d) resistência ao cisalhamento para uma camada espessa de concreto e (e) contenção do movimento dos blocos devido à tração na flexão do revestimento. Adaptado de Hadjigeorgiou \& Ptovin [4]

b) Mecanismo do tipo cesta

Quando a rocha é esmagada por detrás do sistema de suporte, a ação do concreto projetado se assemelha ao de uma malha [6]. Nesse caso, a tenacidade do suporte se torna fundamental para conter a rocha esmagada e suas grandes deformações, como ilustrado na Figura 9(a).

c) Arcos estruturais

O formato de arco solicita a resistência à compressão do concreto projetado, conforme mostrado na Figura 9(b). Caso somente o arco receba os esforços 
solicitantes, como nas obras de mineração, o suporte também será solicitado em suas resistências à flexão e ao cisalhamento, além da perda de aderência entre o concreto e a rocha [6].

d) Reforço dos planos de fraqueza

Os maciços xistosos apresentam prominência de ruptura por flambagem (buckling) quando os planos se posicionam paralelos à escavação (Figura 9(c)) [7]. A aplicação de uma camada de concreto projetado reforça os planos, aumentado a resistência à flambagem (buckling)

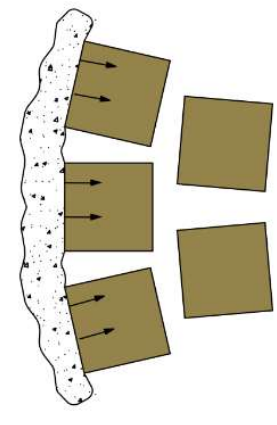

(a)

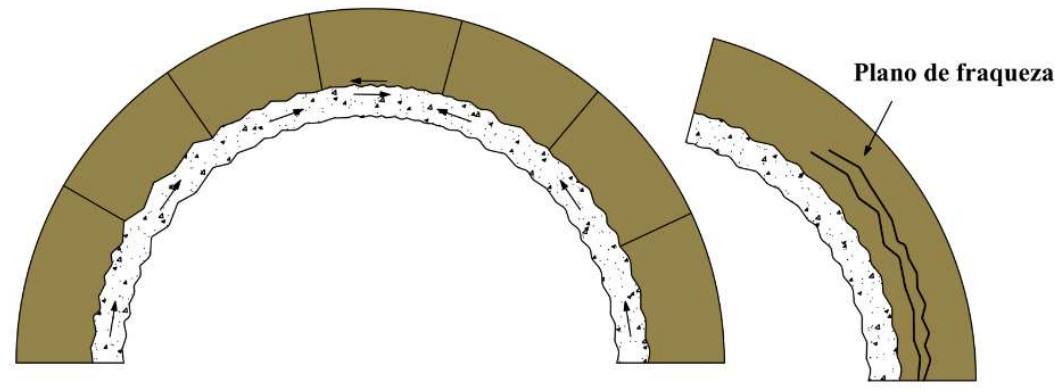

(b) (c)

Figura 9 - Mecanismos de atuação do concreto: (a) cesta, (b) arco estrutural e (c) reforço dos planos de fraqueza. Adaptado de Hadjigeorgiou \& Ptovin [4]

e) Aumento da área de influência do reforço

A combinação de reforços e concreto projetado promove uma transferência de cargas mais eficiente devido a interação entre chapas metálicas e o concreto. A instalação de tirantes é altamente recomendável após a aplicação de concreto projetado [6]. Com a fissuração do revestimento, o reforço consegue conter a queda dos blocos de rocha.

\section{f) Proteção da superfície}

Certos tipos de rocha podem sofrer deterioração quando submetidos à variação de umidade e temperatura [8,9]. A aplicação do revestimento com concreto projetado, portanto, pode funcionar como uma camada protetora tanto para o ambiente quanto mecânica devido à colisão de equipamentos e vibrações. 


\subsection{2.}

\section{Mecanismos de ruptura}

Como observado na seção 2.2.1, durante a ação do concreto projetado em conter as deformações rochosas, diferentes mecanismos de ruptura podem manifestar-se, dependendo da resistência do material e das condições geotécnicas da escavação.

Os estudos de Holmgren [10] e Fernandez-Delgado et al. [11] mostraram que a perda de aderência do concreto e a consequente flexão do revestimento são primordialmente os mecanismos de falha principais a serem analisados. Um trabalho posterior realizado por Barret \& McCreath [12], porém, identificou que a capacidade do concreto projetado de resistir às movimentações do maciço, em condições estáticas, é governada por seis mecanismos: perda de aderência, cisalhamento direto, tração na flexão, punção, resistência à compressão e tração direta. Morton [13] atualizou as definições estabelecidas por Barret \& McCreath [12] e os mecanismos de falha atualizados podem ser analisados na Figura 10.

A falha por aderência entre o concreto projetado e o substrato ao qual ele foi aplicado tem um papel fundamental em definir o limite do mecanismo de falha [12]. Uma boa aderência do concreto projetado depende de uma série de fatores que incluem adequada preparação da superfície [14] e compatibilidade entre concreto projetado e o substrato [15].

Caso a aderência seja mantida e a resistência ao cisalhamento seja alcançada, então a falha do concreto projeto pode ocorrer devido ao cisalhamento direto [12]. Se a aderência é perdida através de seu descolamento, logo, somente o mecanismo de falha por flexão será cinematicamente possível. Caso o concreto projetado apresente algum tipo de reforço como a adição de fibras e a instalação de tirantes, ele ainda consegue efetivamente conter as deformações da rocha, como mostrado na Figura 11. 

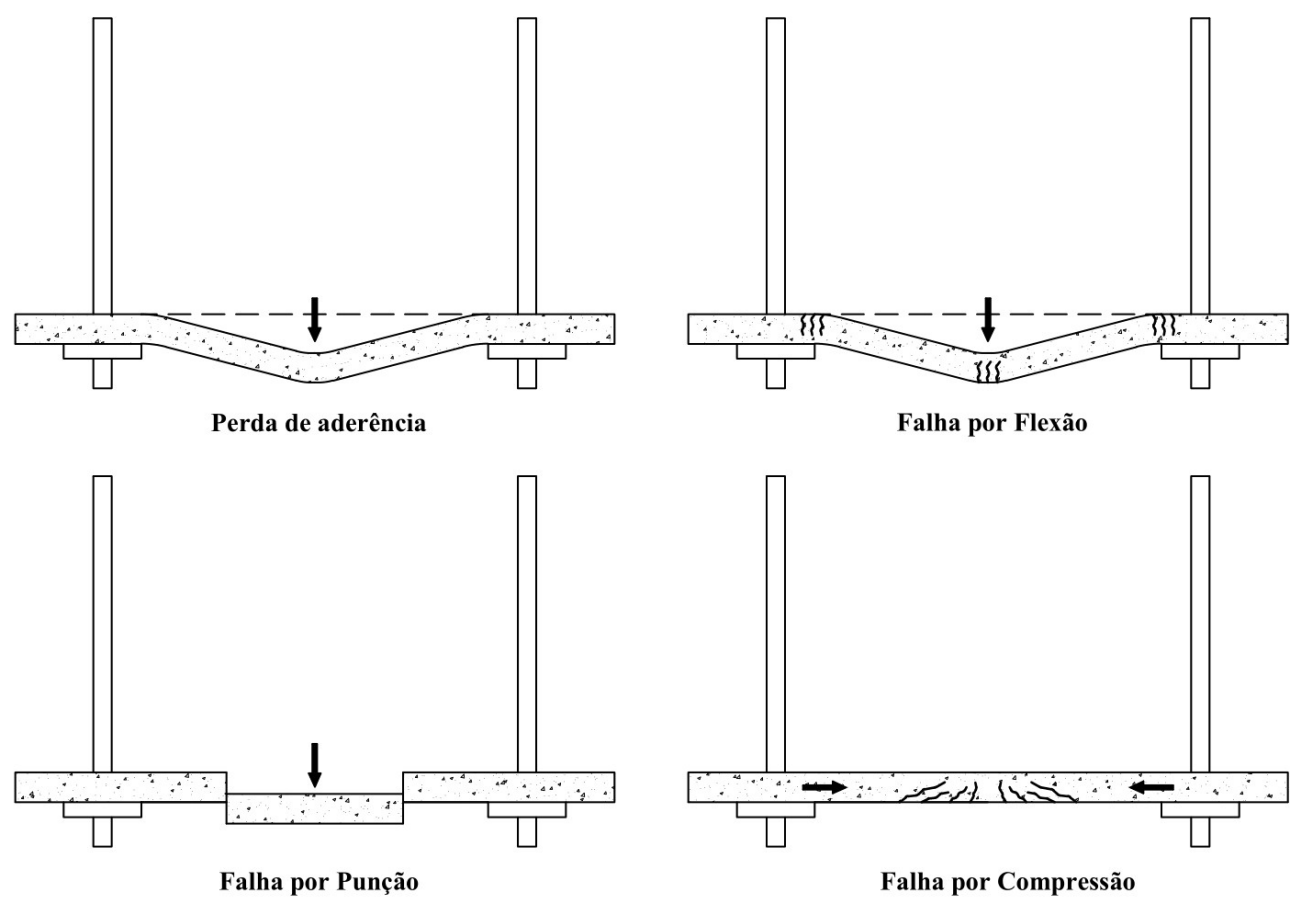

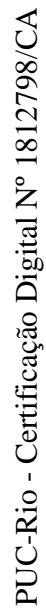
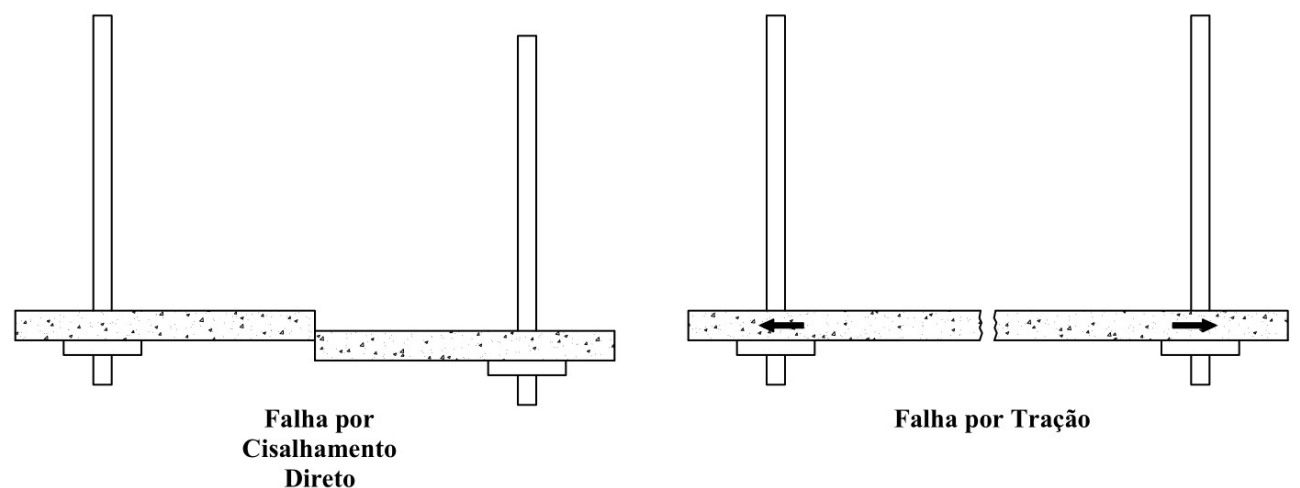

Figura 10 - Mecanismos de falha do concreto projetado. Adaptado por Morton [13]

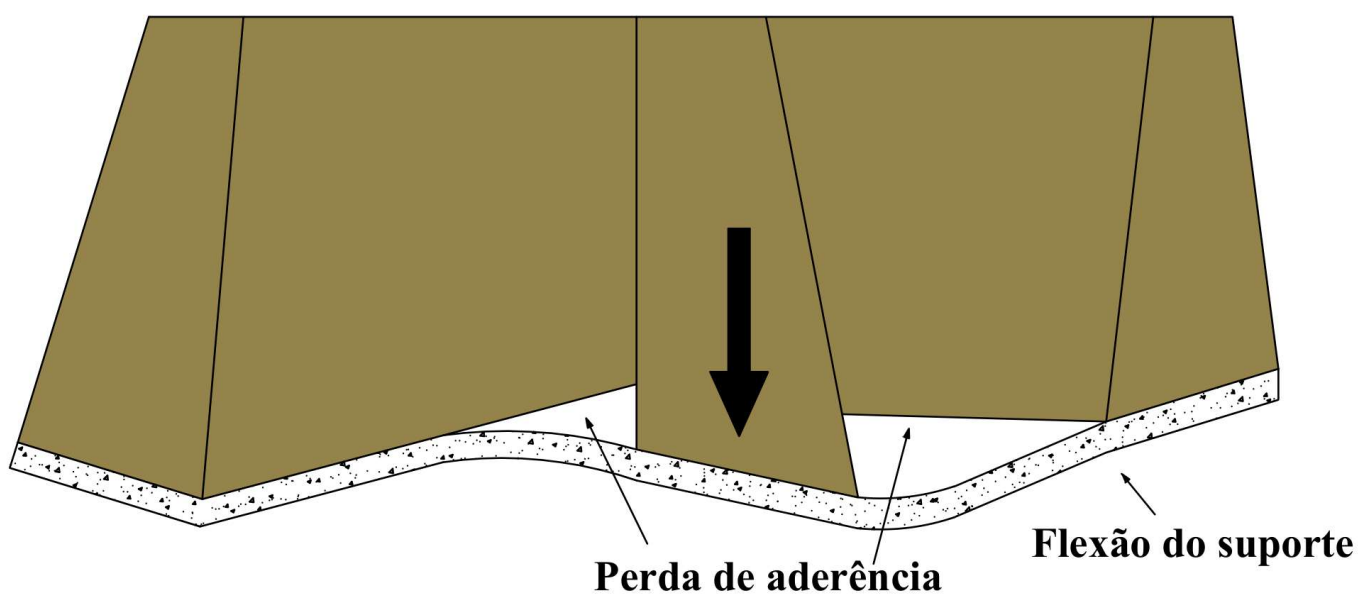

Figura 11 - Flexão do concreto projetado após perda de aderência. Adaptado de Seymour et al. [9] 


\section{3.}

Desenvolvimento do traço

\subsection{1.}

\section{Componentes}

Vários dos princípios do concreto moldado da forma tradicional podem ser aplicados para a dosagem do concreto projetado. As principais diferenças entre eles estão na granulometria do agregado, na quantidade de cimento, no método de transporte, no lançamento e na seleção dos aditivos químicos. Os componentes básicos que compõem o concreto projetado são [16]:

- Cimento.

- Água.

- Agregado.

- Adições e Aditivos.

- Fibras.

Os cimentos nas obras de mineração são os cimentos tradicionais já usados nas obras de infraestrutura [16], que podem ser tanto o cimento Portland CPV de alta resistência inicial ou o cimento Portland composto (CP II) com algum tipo de adição pozolânica ou filer calcário, atendendo às especificações da norma brasileira ABNT 16697 [17]. Além disso, o cimento precisa apresentar compatibilidade com os aditivos químicos como aceleradores e superplastificantes [18].

$\mathrm{O}$ agregado compreende a maior parte do volume da mistura de concreto $\mathrm{e}$ apresenta diferentes especificações em relação à sua distribuição granulométrica. As recomendações europeias para concreto projetado EFNARC [19] apresentam uma faixa de variação do tamanho dos agregados, como indicado na Figura 12. Dessa maneira, o agregado é uma mistura de agregados graúdos com miúdos e limitado a um diâmetro de $12 \mathrm{~mm}$ com o objetivo de evitar o entupimento do equipamento de projeção. 


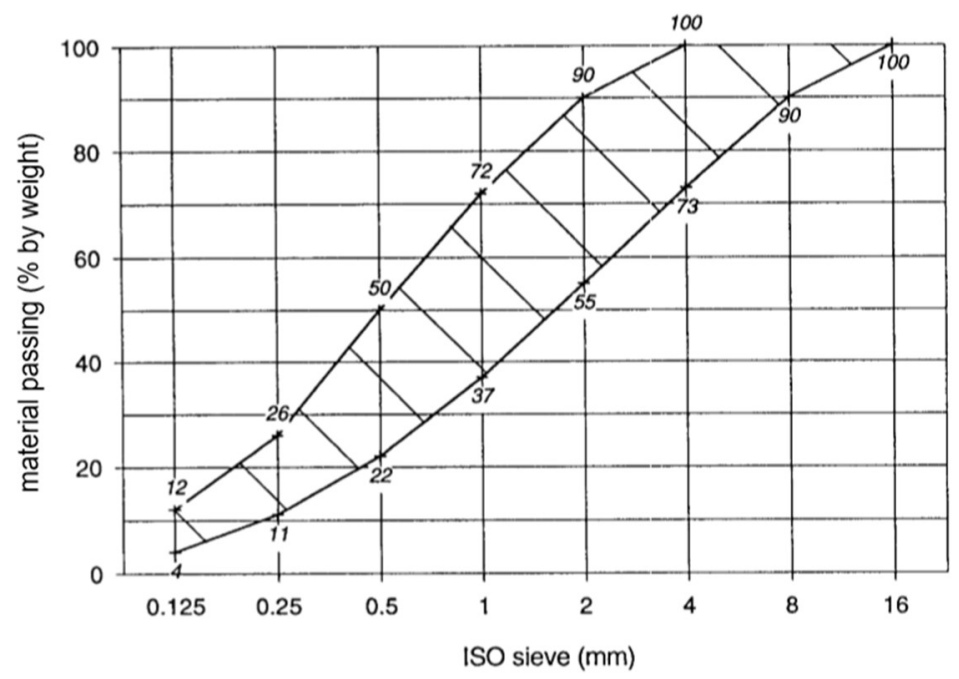

Figura 12 - Faixa de distribuição granulométrica recomendada pela EFNARC [19]

Adições como micro sílica e cinza volante são normalmente usadas com o objetivo de reduzir a quantidade de cimento [20]. No caso das aplicações para concreto projetado em obras de escavação, as adições minerais também ajudam na diminuição da reflexão dos materiais durante a projeção e no aumento da aderência do concreto no substrato [21-23].

Em relação aos aditivos químicos, superplastificantes são usados com o objetivo de garantir a trabalhabilidade e diminuir o fator água-cimento [24]. Os aditivos aceleradores, que promovem a diminuição do tempo de pega, são usados com o objetivo de acelerar o desenvolvimento da resistência inicial do concreto [25]. A principal vantagem no seu uso está no aumento da velocidade de construção e no aumento da aderência nas primeiras idades [16].

Fibras de aço e polipropileno são as principais fibras usadas atualmente em obras de escavação [26]. Elas são adicionadas à mistura com o objetivo de promover um aumento na resistência pós-fissuração e na capacidade de deformação para conter os deslocamentos dos blocos de rocha [27]. Como o uso do concreto projetado com fibras requer um menor tempo de instalação quando comparado com a instalação das malhas soldadas, o uso desse material se tornou um dos principais sistemas de suporte a serem utilizados em obras de escavação subterrânea [28]. 


\subsection{2.}

\section{Dosagem do concreto projetado}

A dosagem do concreto projetado varia dependendo do método de projeção aplicado, que pode ser por via úmida [29] ou por via seca [30]. Na projeção por via seca, o cimento e os agregados são misturados previamente, lançados na máquina de projeção e, por fim, a água é introduzida no bico de projeção. Na via úmida todos os materiais são misturados no abastecimento da máquina de projeção. Em obras de infraestrutura e de escavação, a projeção de concreto é feita principalmente por via úmida. De acordo com Hoek \& Brown [31], o processo de dosagem do concreto projetado deve levar em consideração os seguintes fatores:

- Capacidade de projeção: o material deve ter capacidade de ser projetado com o mínimo de reflexão;

- Resistência inicial: o concreto deve apresentar uma resistência suficiente para conter as deformações rochosas entre 4 e 8 horas após seu lançamento;

- Resistência em idades avançadas: precisa atingir a resistência especificada em projeto após 28 dias;

- Durabilidade;

- Economia: alcançar o melhor custo-benefício.

Baseado nos requisitos acima, Jolin \& Beaupre [29] recomendam uma dosagem básica para concreto projetado, como mostrado na Tabela 1. Outras dosagens similares podem ser encontradas nos guias europeu EFNARC [19] e australiano AuSS [16].

Tabela 1 - Dosagem básica para concreto projetado por Jolin \& Beaupre [29]

\begin{tabular}{cc}
\hline Componente & Quantidade para $1 \mathrm{~m}^{3}$ \\
\hline Cimento & $400 \mathrm{~kg}$ \\
Agregado Miúdo & $1110 \mathrm{~kg}$ \\
Agregado Graúdo & $460 \mathrm{~kg}$ \\
Água & $180 \mathrm{~kg}$ \\
Microsílica & $40 \mathrm{~kg}$ \\
Aditivo redutor de água & $1500 \mathrm{ml}$ \\
Superplastificante & $5000 \mathrm{ml}$ \\
Incorporador de ar & $2500 \mathrm{ml}$ \\
\hline
\end{tabular}




\subsection{3.}

\section{Tipos de fibra}

Paralelamente ao estudo da dosagem do concreto projetado, há também um constante desenvolvimento na tecnologia de produção das fibras. Uma grande variedade de fibras já foi estudada e desenvolvida para aplicações com materiais cimentícios como as fibras de aço, vidro, sintéticas e naturais [32]. Para as aplicações em obras de escavação e infraestrutura, por outro lado, as principais fibras usadas são as de aço e sintéticas [26].

Os principais parâmetros que caracterizam a fibra são seu módulo de elasticidade, resistência à tração e fator de forma [33]. O fator de forma pode ser definido como o comprimento da fibra dividido pelo seu diâmetro equivalente [32]. A Tabela 2 apresenta as principais características de algumas das fibras estudadas na atualidade.

O tamanho de fibra de aço usado em concreto projetado costuma variar entre $19 \mathrm{~mm}$ até $32 \mathrm{~mm}$ de comprimento com cerca de $0,40 \mathrm{~mm}$ de diâmetro [26]. A EFNARC [19] recomenda que o comprimento das fibras de aço não ultrapasse 70\% do diâmetro interno das mangueiras de projeção para evitar o entupimento do equipamento. Não há recomendações semelhantes para as fibras sintéticas.

Já as fibras de polipropileno que vêm sendo usadas em concreto projetado apresentam um comprimento entre $12 \mathrm{~mm}$ até $50 \mathrm{~mm}$ [26]. Geralmente o método de adição das fibras sintéticas na mistura é semelhante aos da fibra de aço, já que elas não apresentam a mesma suscetibilidade de entupimento das mangueiras como as fibras de aço. Por outro lado, problemas de mistura podem ocorrer ao aplicar frações volumétricas acima de $6 \mathrm{~kg} / \mathrm{m}^{3}$ [26].

Tabela 2 - Propriedades típicas de fibras usadas como reforço

\begin{tabular}{cccc}
\hline Material & $\begin{array}{c}\text { Módulo de Elasticidade } \\
(\mathrm{GPa})\end{array}$ & $\begin{array}{c}\text { Resistência à Tração } \\
(\mathrm{MPa})\end{array}$ & Fonte \\
\hline Aço & 210 & 1345 & Nogueira [106] \\
Vidro & 70 & 2900 & Adusumalli et al. [124] \\
Polipropileno & 2,29 & 260 & Castoldi [107] \\
Carbono & 250 & 4000 & Mansur [125] \\
Sisal & 8,77 & 383 & Castoldi [107] \\
\hline
\end{tabular}




\section{4.}

\section{Dimensionamento do concreto projetado}

O dimensionamento do concreto projetado ainda não é bem definido, especialmente em condições precárias do maciço rochoso [35]. Além disso, a combinação do concreto projetado com os tirantes e telas torna a análise da contribuição de cada suporte ainda mais complexa [36]. Como resultado, o dimensionamento é baseado principalmente em experiências passadas [37]. A Figura 13 ilustra a contenção das deformações rochosas com a ação combinada do concreto projetado com os tirantes.

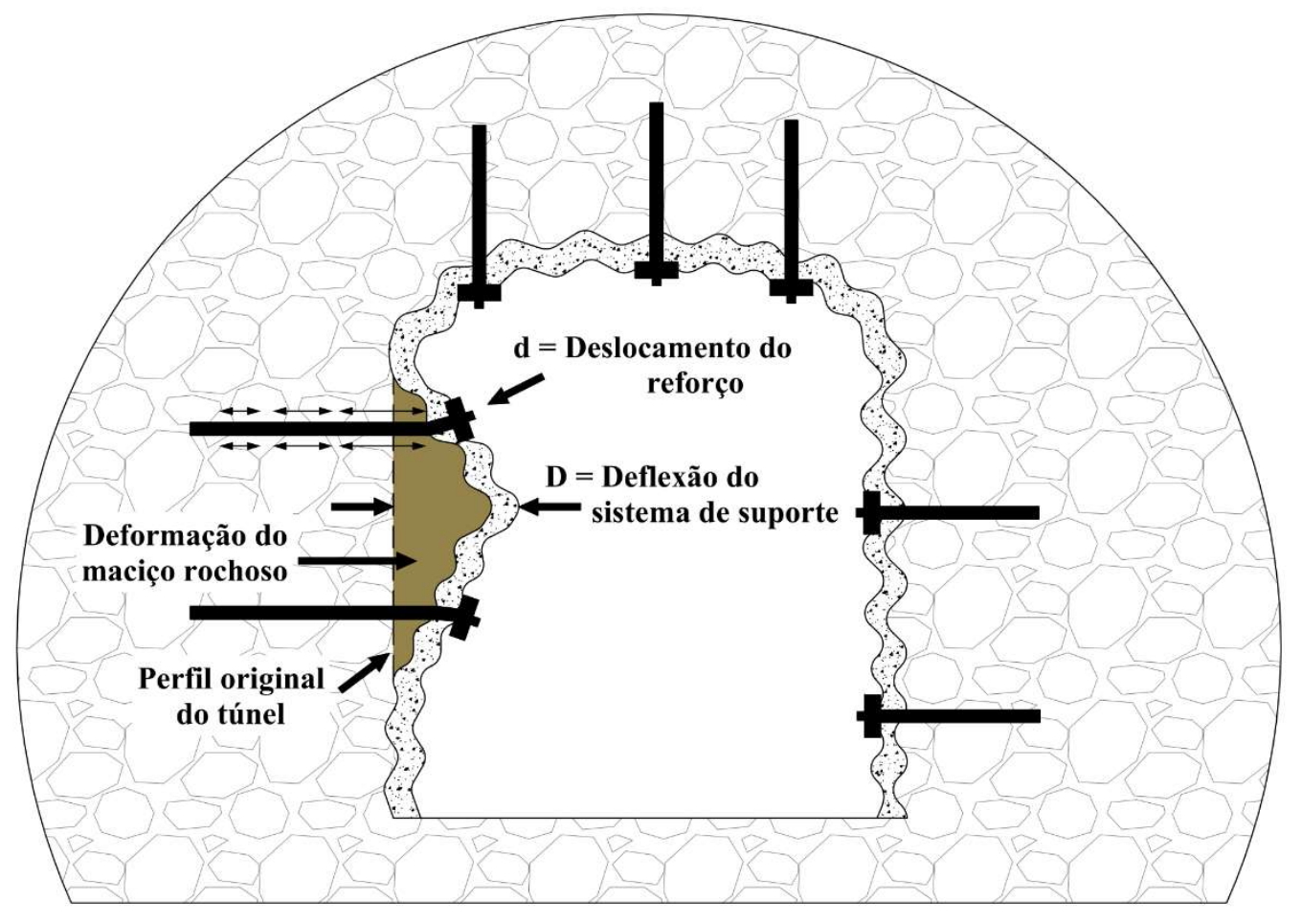

Figura 13 - Contenção das deformações da rocha com a ação combinada do concreto projetado e dos tirantes. Adaptado de Martin et al. [37]

O dimensionamento empírico usualmente fornece algumas orientações gerais para a espessura de concreto projetado ou reforço baseado na classificação dos maciços rochosos, espaçamento entre tirantes, entre outros parâmetros. Os principais sistemas de classificação de rochas usados no dimensionamento incluem o sistema Q [38], o sistema RMR ou classificação de Bieniawski [39] e a classificação geomecânica RSR [40].

O método RSR (Rock Structure Rating), desenvolvido por Wickham et al. [40] em 1972, foi um dos principais métodos a referenciar o concreto projetado 
como sistema de suporte, apesar dos principais casos usados para o desenvolvimento do método forem túneis relativamente pequenos [41]. A Figura 14 mostra um conjunto de curvas típicas utilizadas para o dimensionamento do concreto projetado em conjunto com os tirantes e cambotas, baseado no sistema RSR para túneis com 7,3 m de diâmetro.

Bieniawski [42] publicou uma atualização de seu método de classificação de rochas chamado de Rock Mass Rating (RMR). Seis parâmetros são usados para classificar a rocha:

1. Resistência à compressão da rocha;

2. Designação da qualidade da rocha (RQD);

3. Espaçamento das descontinuidades;

4. Condição das descontinuidades;

5. Condição das águas subterrâneas;

6. Orientação das descontinuidades.

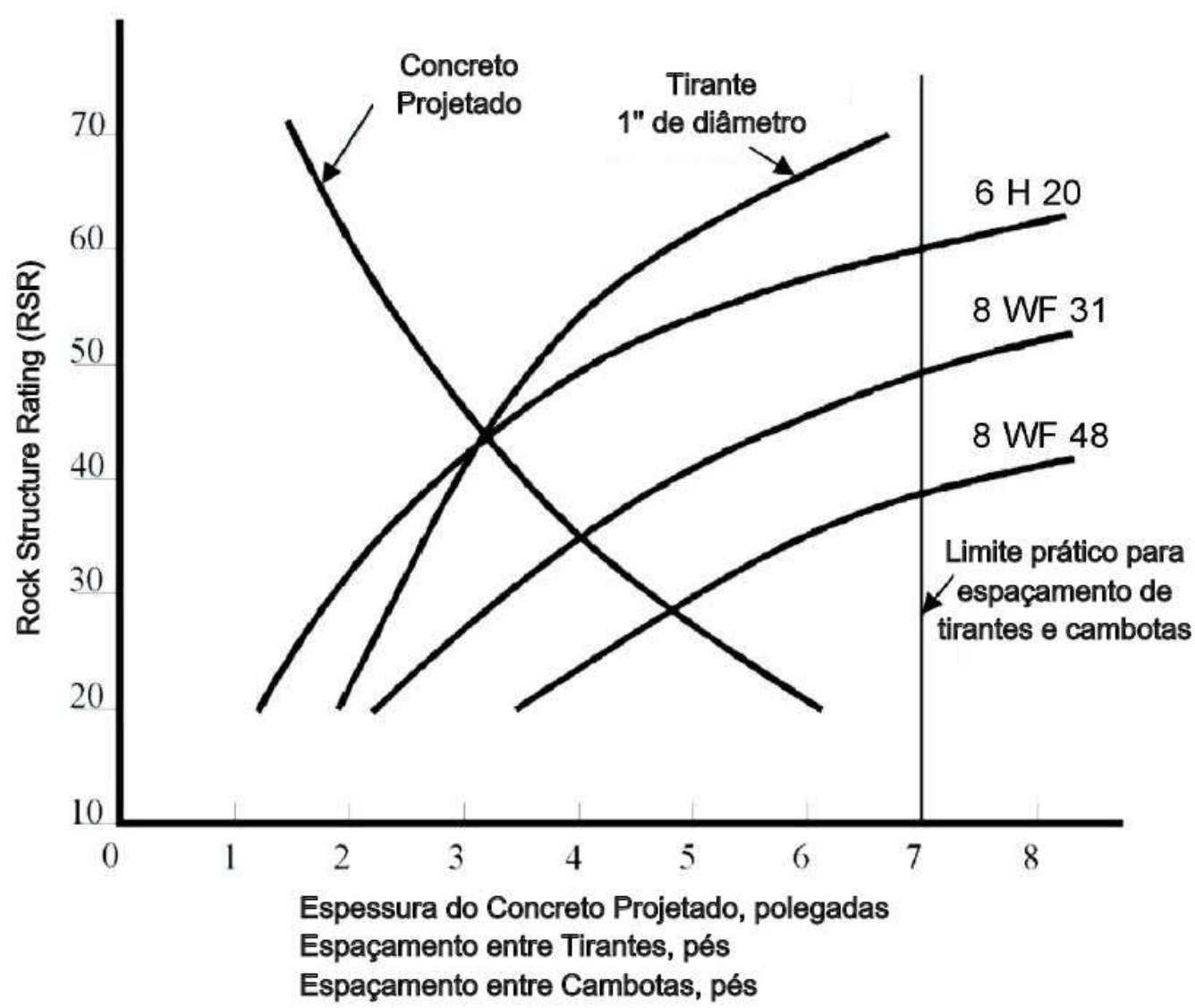

Figura 14 - Dimensionamento de suporte e reforço para túnel circular com 7,3 m de diâmetro de acordo com o método RSR. Adaptado de Hoek [41] 
Ao aplicar essa classificação, o maciço rochoso é dividido em uma série de regiões e cada região é classificada separadamente [41]. As fronteiras de cada região da escavação são definidas a partir de uma mudança no tipo de rocha ou uma mudança significativa nas características das descontinuidades.

Dessa maneira, é possível dividir a rocha em diversas classes iniciando em I (rocha muito boa) até V (rocha muito fraca). Para cada classe de rocha, recomendase um tipo de suporte baseado na espessura de concreto projetado, no espaçamento de tirantes e cambotas, como mostrado na Tabela 3.

Tabela 3 - Recomendação de dimensionamento de suporte de acordo com a classificação RMR

\begin{tabular}{|c|c|c|c|c|}
\hline $\begin{array}{l}\text { Classe do } \\
\text { Maciço } \\
\text { Rochoso } \\
\end{array}$ & Escavação & $\begin{array}{l}\text { Tirantes (diâmetro de } \\
20 \text { mm, rebocado) }\end{array}$ & $\begin{array}{l}\text { Concreto } \\
\text { Projetado }\end{array}$ & Cambotas \\
\hline $\begin{array}{l}\text { I } \\
\text { Rocha Muito } \\
\text { Boa } \\
\text { RMR: } 81-100 \\
\end{array}$ & $\begin{array}{l}\text { Face completa. } 3 \text { metros de } \\
\text { avanço. }\end{array}$ & \multicolumn{3}{|c|}{ Geralmente, nenhum suporte necessário exceto por cavilhas locais. } \\
\hline $\begin{array}{l}\text { II } \\
\text { Rocha Boa } \\
\text { RMR: } 61-80\end{array}$ & $\begin{array}{l}\text { Face completa. } 1 \text { - } 1,5 \text { metros de } \\
\text { avanço. Suporte completo a } 20 \\
\text { metros da face. }\end{array}$ & $\begin{array}{l}\text { Localmente, } \\
\text { tirante/cavilhas no topo } \\
\text { com } 3 \text { metros de } \\
\text { extensão, espaçados em } \\
2,5 \text { metros com tela } \\
\text { ocasionalmente. }\end{array}$ & $\begin{array}{l}50 \mathrm{~mm} \text { no topo } \\
\text { onde } \\
\text { necessário. }\end{array}$ & Desnecessário. \\
\hline $\begin{array}{l}\text { III } \\
\text { Rocha } \\
\text { Razoável } \\
\text { RMR: } 41-60\end{array}$ & $\begin{array}{l}\text { Topo e meio da galeria. } 1,5-3 \\
\text { metros em avanço no galeria } \\
\text { superior. Suporte Inicial após cada } \\
\text { detonação. Suporte completo a } 10 \\
\text { metros da face. }\end{array}$ & $\begin{array}{l}\text { Tirantes/cavilha } \\
\text { sistemático com } 4 \\
\text { metros de extensão, } \\
\text { espaçados a } 1,5-2 \\
\text { metros no topo e } \\
\text { paredes com tela no } \\
\text { topo. }\end{array}$ & $\begin{array}{l}50-100 \mathrm{~mm} \\
\text { no topo e } 30 \\
\text { mm nas } \\
\text { laterais. }\end{array}$ & Desnecessário. \\
\hline $\begin{array}{l}\text { IV } \\
\text { Rocha Fraca } \\
\text { RMR - } 21-40\end{array}$ & $\begin{array}{l}\text { Topo e meio da galeria. } 1,0-1,5 \\
\text { metros em avanço no topo da } \\
\text { galeria. Instalar suporte } \\
\text { simultaneamente a escavação, a } 10 \\
\text { metros da } \\
\text { face. }\end{array}$ & $\begin{array}{l}\text { Tirantes/cavilha } \\
\text { sistemáticos de } 4-5 \\
\text { metros de extensão, } \\
\text { espaçados a } 1-1,5 \\
\text { metros } \\
\text { no topo e paredes com } \\
\text { tela. }\end{array}$ & $\begin{array}{l}100-150 \mathrm{~mm} \\
\text { no topo e } 100 \\
\text { mm nas } \\
\text { laterais. }\end{array}$ & $\begin{array}{l}\text { Cambotas leves a } \\
\text { médias espaçadas a } \\
1,5 \text { metros onde } \\
\text { necessário. }\end{array}$ \\
\hline $\begin{array}{l}\text { V - Rocha } \\
\text { Muito Fraca } \\
\text { RMR }<20\end{array}$ & $\begin{array}{l}\text { Múltiplos drifts a } 0,5-1,5 \text { metros } \\
\text { em avanço no topo da galeria. } \\
\text { Instalar suporte simultaneamente a } \\
\text { escavação. Concreto } \\
\text { projetado assim que possível } \\
\text { após a detonação. }\end{array}$ & $\begin{array}{l}\text { Tirantes/cavilhas } \\
\text { sistemáticos com } 5-6 \\
\text { metros de extensão, } \\
\text { espaçados de } 1-1,5 \\
\text { metros no topo e } \\
\text { paredes } \\
\text { com tela. }\end{array}$ & $\begin{array}{l}150-200 \mathrm{~mm} \\
\text { no topo, } 150 \\
\text { mm nas } \\
\text { laterais e } 50 \\
\text { mm na face. }\end{array}$ & $\begin{array}{l}\text { Cambotas médias e } \\
\text { pesadas espaçadas a } \\
0,75 \text { metro com } \\
\text { cobertura metálica e } \\
\text { pré-suporte } \\
\text { temporário se } \\
\text { necessário. }\end{array}$ \\
\hline
\end{tabular}

Barton et al. [43] propôs um novo sistema de classificação chamado de sistema Q que qualifica os maciços rochosos. O valor numérico do índice $Q$ varia em uma escala logarítmica de 0,001 até um máximo de 1000 e é calculado pela Equação (1). 


$$
Q=\frac{R Q D}{J_{n}} \times \frac{J_{r}}{J_{a}} \times \frac{J_{w}}{S R F}
$$

onde cada dos parâmetros pode ser definido da seguinte maneira:

1. RQD é a designação da qualidade da rocha;

2. $\mathrm{J}_{\mathrm{n}}$ é o número de famílias de juntas;

3. $\mathrm{J}_{\mathrm{r}}$ é a rugosidade das juntas;

4. $\mathrm{J}_{\mathrm{a}}$ é o grau de alteração das juntas;

5. $\mathrm{J}_{\mathrm{w}}$ é o fator de redução pelo fluxo interno de água;

6. SRF é a condição de tensões

O primeiro termo $\left(\mathrm{RQD} / \mathrm{J}_{\mathrm{n}}\right)$ da Equação (1) é uma medida do tamanho dos blocos das juntas, o segundo expressa a resistência ao cisalhamento das superfícies da rocha e o último avalia as condições ambientais que influenciam no comportamento da rocha [44].

O índice RQD (Designação da qualidade da rocha) foi desenvolvido por Deere \& Deere. [45] para mensurar a qualidade do maciço rochoso a partir de amostras perfuradas. RQD pode ser definido como o percentual de recuperação de pedaços do núcleo com mais de $100 \mathrm{~mm}$ de comprimento analisado.

Dessa maneira, a partir dos resultados obtidos pelos parâmetros descritos acima e pela Equação (1), é possível classificar o maciço de acordo com a Tabela 4 [44]. Em seguida, é possível realizar o dimensionamento do sistema de suporte a partir do ábaco desenvolvido por Grimstad \& Barton [46] já com a inclusão do concreto projetado com fibras, conforme mostrado na Figura 14.

Tabela 4 - Classificação do maciço rochoso a partir do sistema Q (Barton et al. [43])

\begin{tabular}{cc}
\hline $\mathrm{Q}$ & Qualidade do Maciço Rochoso \\
\hline$<0,01$ & Extraordinariamente Fraca \\
$0,01-0,1$ & Extremamente Fraca \\
$0,1-1,0$ & Muito Fraca \\
$1,0-4,0$ & Fraca \\
$4,0-10,0$ & Razoável \\
$10,0-40,0$ & Boa \\
$40,0-100,0$ & Muito Boa \\
$100,0-400,0$ & Extremamente Boa \\
$>400,0$ & Extraordinariamente Boa \\
\hline
\end{tabular}




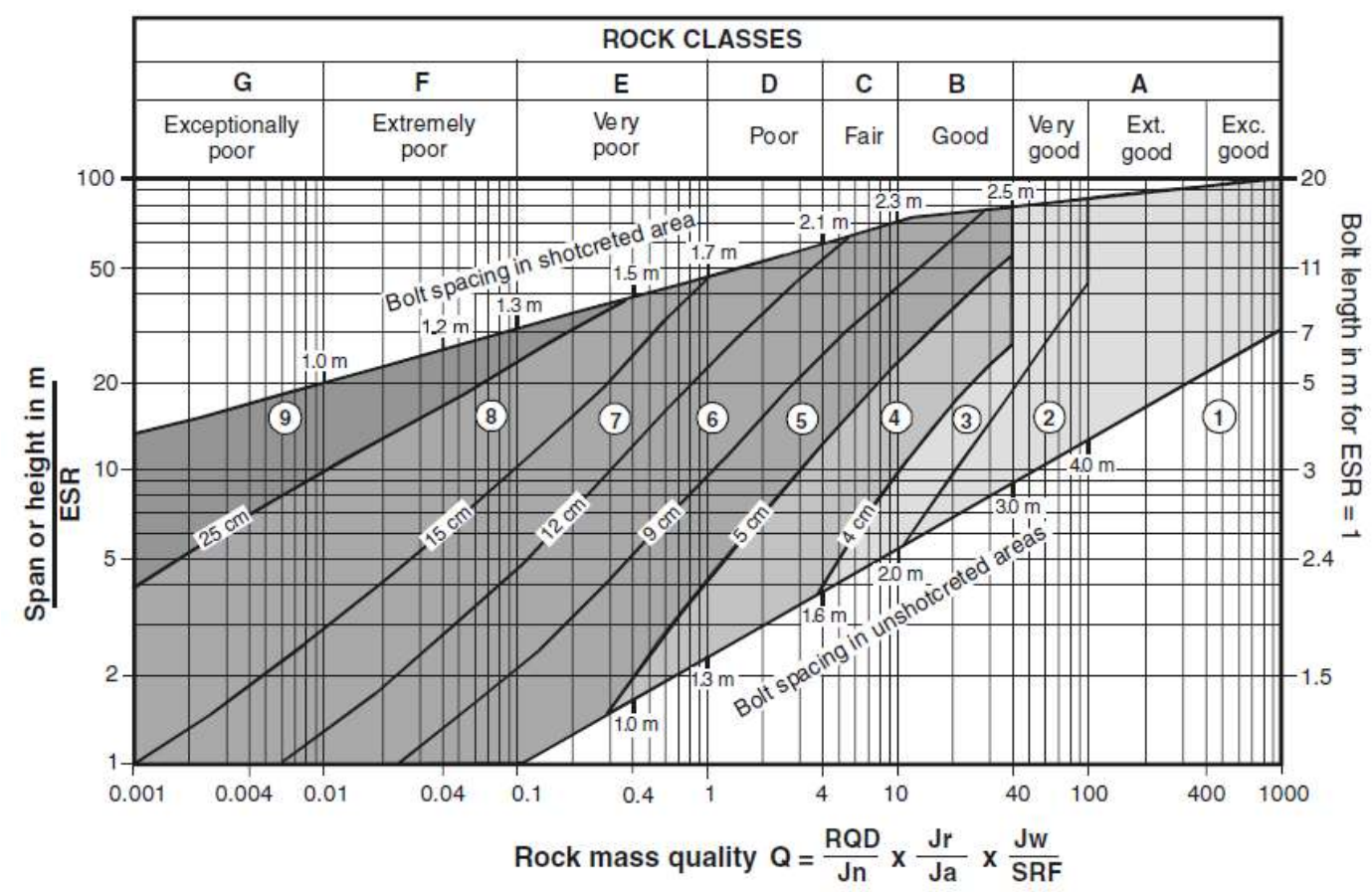

REINFORCEMENT CATEGORIES:

1) Unsupported

2) Spot bolting

3) Systematic bolting

4) Systematic bolting, (and unreinforced shotcrete, $4-10 \mathrm{~cm}$ )

5) Fibre reinforced shotcrete and bolting, $5-9 \mathrm{~cm}$

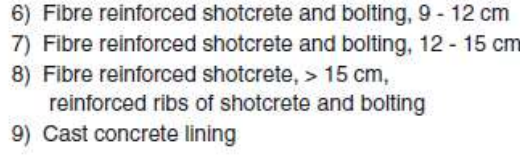

6) Fibre reinforced shotcrete and bolting, $9-12 \mathrm{~cm}$

7) Fibre reinforced shotcrete and bolting, $12-15 \mathrm{~cm}$

8) Fibre reinforced shotcrete, $>15 \mathrm{~cm}$,

reinforced ribs of shotcrete and bolting

9) Cast concrete lining

Figura 15 - Dimensionamento do sistema de suporte a partir da classificação pelo sistema Q a partir de Grimstad \& Barton [40] (Palmstrom \& Broch [47])

É possível perceber, a partir da Figura 15, que o dimensionamento desenvolvido por Grimstad \& Barton [46] não específica qual tipo e a fração volumétrica da fibra a ser usada no concreto projetado. Papworth [48], por sua vez, correlaciona a classificação do sistema Q com os valores de tenacidade obtidos a partir dos ensaios de flexão em painéis circulares, de acordo com a norma americana ASTM C1550 [49], e os ensaios em painéis quadrados, de acordo com a norma EN 14488-5 [50] e EFNARC [19]. A tenacidade é dividida em diferentes índices de performance de tenacidade (TPL) que variam de 0 a IV. Essa correlação pode ser analisada na Tabela 5.

O ábaco de dimensionamento proposto por Grimstad \& Barton [43] indica que a espessura de concreto projetado e o reforço devem aumentar com a piora das condições da rocha e para maiores vãos de escavação. Além da adição do concreto projetado e do reforço, recomenda-se o uso de tirantes ao sistema de suporte em quase todas as categorias propostas pelo dimensionamento. Em boas condições da rocha, a tenacidade pós-pico não apresenta tanta relevância, já que o papel 
fundamental do concreto projetado é o de prevenir a queda de blocos de rocha por entre os tirantes. A verificação da tenacidade é prioridade em casos de baixa qualidade das condições da rocha e onde há expectativa de grandes deformações.

Tabela 5 - Correlação entre a qualidade do maciço rochoso do sistema Q e a tenacidade obtida dos ensaios de painel (Papworth [48])

\begin{tabular}{ccccc}
\hline Qualidade do Maciço Rochoso & \multicolumn{3}{c}{ Tenacidade } \\
\hline TPL* $^{*}$ & Classe & $\begin{array}{c}\text { EFNARC } \\
\text { (Joules) }\end{array}$ & $\begin{array}{c}\text { RDP }_{40 \mathrm{~mm}} \\
\text { (Joules) }\end{array}$ & $\begin{array}{c}\text { RDP }_{80 \mathrm{~mm}} \\
\text { (Joules) }\end{array}$ \\
\hline IV & - & $>1400$ & $>560$ & $>840$ \\
IV & F & $>1000$ & $>400$ & $>600$ \\
III & E & $>700$ & $>280$ & $>420$ \\
II & D & $>500$ & $>200$ & $>300$ \\
I & C & $>500$ & $>200$ & $>300$ \\
0 & B & 0 & 0 & 0 \\
\hline
\end{tabular}

* Índice de Performance de Tenacidade

Até o fim da seção 2.4, esse trabalho trouxe alguns dos principais aspectos teóricos do dimensionamento e da análise do concreto projetado para sistemas de suporte em obras de mineração. Devido à rara quantidade de produções na língua portuguesa, essa primeira etapa da revisão bibliográfica visa trazer algumas das principais referências e discussões sobre os principais mecanismos dos sistemas de suporte para a consulta dos engenheiros que atuam nas inúmeras minas do Brasil.

\section{5.}

\section{Comportamento mecânico do concreto projetado}

Segundo Bentur \& Mindess [32], o comportamento à flexão do concreto com fibras é diretamente afetado pela fração volumétrica e pelo fator de forma das fibras. Em relação ao teor de fibras, um aumento até o volume crítico, em geral, resulta em uma maior resistência residual pós-pico e tenacidade. Entretanto, volumes muito superiores ao crítico podem resultar em redução do desempenho, devido à dificuldade de dispersão das fibras e à perda de trabalhabilidade do material.

A Figura 16 apresenta uma curva típica de concretos reforçados com fibra submetidos à flexão, dividida em três diferentes estágios. $\mathrm{O}$ estágio I representa $\mathrm{o}$ comportamento linear do compósito até atingir a resistência de fissuração da matriz. 
O estágio II caracteriza-se por um comportamento não linear no qual ocorre a a transferência de tensões pelas fissuras do cocnreto [51]. Para altos teores de fibra, as fibras tendem a ser arrancadas gradualmente da matriz até a carga última (hardening). Após atingir a carga máxima, há o completo arrancamento das fibras e a capacidade de carga passa a ser reduzida progressivamente. Em caso de baixos teores, o estágio II caracteriza-se pelo decréscimo da curva após alcançar a resistência de fissuração (softening).

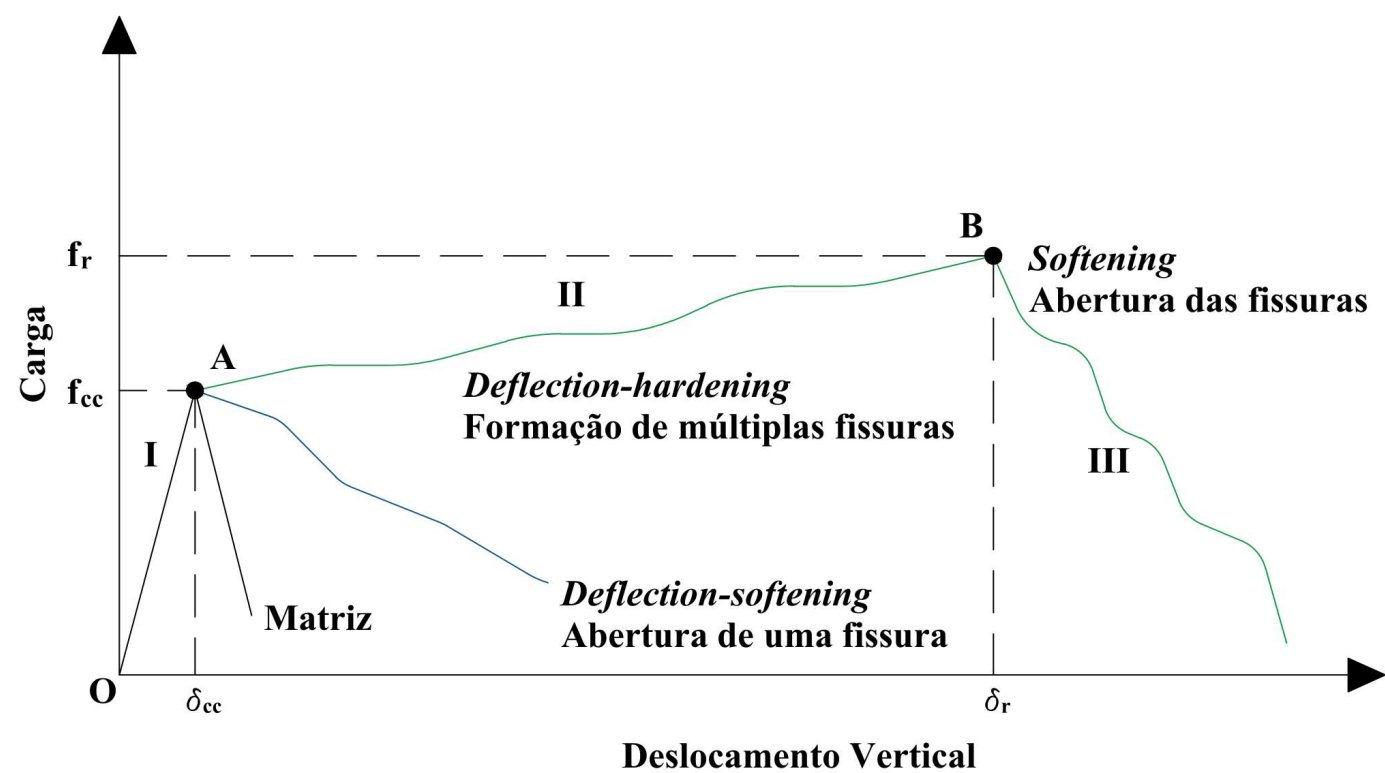

Figura 16 - Conceitos de hardening e softening para a classificação do comportamento mecânico do concreto com fibras. Adaptado de Mobasher [68]

Além disso, Figueiredo [34] afirma que o módulo de elasticidade e a resistência à tração da fibra afetam diretamente o comportamento pós-fissuração. A resistência à tração da fibra contribui para o comportamento mecânico do compósito no momento em que ocorre a fissura, já que há uma transferência de tensões da matriz para a fibra [58]. O módulo de elasticidade, por outro lado, reflete na rigidez e na capacidade de conter a propagação de fissuras no compósito do material.

Diversos métodos têm sido propostos como alternativa para caracterizar o concreto reforçado com fibras com respeito à tenacidade e resistência à tração. As principais normas e trabalhos já desenvolvidos determinam as propriedades mecânicas do material a partir de ensaios de flexão em três ou quatro pontos em corpos de prova prismáticos com ou sem entalhe (ASTM C1609 [52], RILEM TC 162-TDF [53], EN 14651 [54], CEB-FIB [55] e Mobasher et al. [56]). Uma 
característica importante dos ensaios de flexão, segundo Minelli \& Plizzari [57] está na grande dispersão nos resultados, devido à pequena área de fissuração e a um pequeno número de fibras na seção fissurada.

Para se avaliar a tenacidade do concreto projetado reforçado com fibras, recomenda-se utilizar os ensaios de flexão em painéis quadrados ou circulares (EFNARC [19] e ASTM C1550 [49]), que tentam simular de forma mais apropriada as condições de carregamento e deformação em obras de escavação. Os ensaios de painel mostram uma variação menor nos resultados quando comparado com os obtidos nos ensaios de flexão em prismas, segundo Minelli et al. [59]. Porém, possuem a desvantagem da difícil execução e transporte, devido às suas grandes dimensões.

Uma das principais dúvidas em relação ao concreto projetado com fibras em obras de mineração está na escolha e na fração volumétrica da fibra. Mais recentemente, com o desenvolvimento das fibras sintéticas e a maior concorrência entre as empresas fabricantes de fibras, começou-se a vender uma ideia de que as fibras sintéticas podem providenciar a mesma performance mecânica que as fibras de aço por um preço menor por metro cúbico e durabilidade aprimorada (sem corrosão).

Diferentes autores, portanto, realizaram uma série de ensaios de tenacidade em painéis circulares reforçados com fibras sintéticas e de aço de diferentes geometrias e de acordo com a norma ASTM C1550 [46]. Segundo Nitschke \& Winterberg [60], $55 \mathrm{~J}$ para cada $\mathrm{kg} / \mathrm{m}^{3}$ de fibra sintética podem ser esperados como hipótese inicial a partir dos ensaios de flexão em painel. No caso das fibras de aço, Bernard [61] e Bernard et al. [62] estudaram não só o comportamento mecânico do concreto projetado com fibras de aço como também a dispersão dos resultados e sua correlação com os ensaios de flexão em prismas. Os resultados de tenacidade em painéis circulares, os tipos e as frações volumétricas de fibra utilizadas estão resumidos na Tabela 6 e na Figura 17. O dimensionamento foi realizado de acordo com a Tabela 5 . 


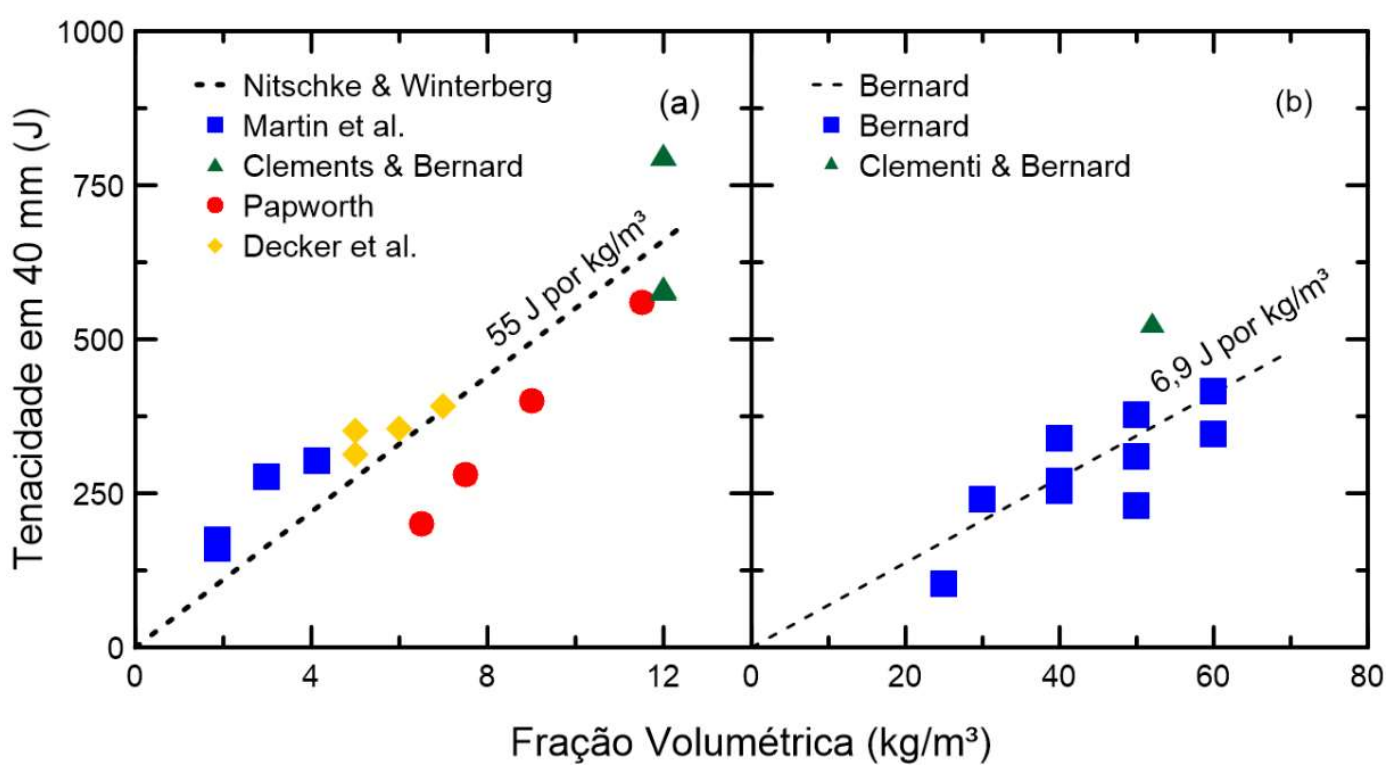

Figura 17 - Resultados publicados de tenacidade em painéis circulares (ASTM C1550 [49]) para o concreto projetado reforçado com fibras (a) sintéticas e (b) de aço

Como esperado, os valores de tenacidade alcançados pelos autores diferem consideravelmente com o tipo, a geometria e a fração volumétrica das fibras analisadas. Papworth [48], por exemplo, apresenta resultado de tenacidade menores quando comparado ao concreto reforçado com fibras sintéticas de Martin et al. [63]. Já o concreto reforçado com fibras de aço analisado por Bernard [61] pode apresentar uma menor capacidade de absorção de energia em relação ao material com fibras sintéticas dependendo da fração volumétrica analisada.

Cengiz \& Turanli [66] e Ratcliffe [67] compararam o comportamento à flexão do concreto projetado reforçado com fibras de aço, sintéticas e tela de aço através de ensaios em painéis quadrados de acordo com a EFNARC [19]. A adição de altas frações volumétricas de fibras sintéticas $\left(7 \mathrm{~kg} / \mathrm{m}^{3}\right.$ e $\left.10 \mathrm{~kg} / \mathrm{m}^{3}\right)$ proporcionou valores de tenacidade um pouco maiores do obtido com a adição de $35 \mathrm{~kg} / \mathrm{m}^{3}$ de fibras de aço. O concreto reforçado com a tela de aço apresentou uma capacidade de absorção de energia consideravelmente maior do que o concreto reforçado com fibras, independentemente do tipo ou fração volumétrica.

Dessa maneira, a escolha do tipo de fibra e da fração volumétrica devem ser realizadas após a realização dos ensaios mecânicos propostos por norma. Vale ressaltar, que o comportamento mecânico do concreto projetado também depende da matriz utilizada e frações volumétricas muito altas de fibra podem acarretar em problemas de trabalhabilidade e lançamento do material [26]. 
Tabela 6 - Resultados publicados de tenacidade para diferentes fibras sintéticas e aço através dos ensaios de flexão em painel circular (ASTM C1550 [49])

\begin{tabular}{|c|c|c|c|c|}
\hline Referência & Tipo de Fibra & $\begin{array}{c}\text { Fração } \\
\text { Volumétrica } \\
\left(\mathrm{kg} / \mathrm{m}^{3}\right)\end{array}$ & $\begin{array}{l}\text { Tenacidade } \\
(\mathrm{J})\end{array}$ & $\begin{array}{l}\text { TPL*, } \\
\text { Classe de Rocha }\end{array}$ \\
\hline \multirow{4}{*}{$\begin{array}{l}\text { Martin et al. } \\
\text { [63] }\end{array}$} & BarChip Shogun 48 & 1,87 & 160 & $0, \mathrm{~A}$ \\
\hline & BarChip Shogun 48 & 2,99 & 276 & $\mathrm{I} / \mathrm{II}, \mathrm{B} / \mathrm{C}$ \\
\hline & BarChip Shogun 48 & 4,12 & 302 & III, D \\
\hline & Fabpro Perfomax 48 & 1,87 & 175 & $0, \mathrm{~A}$ \\
\hline \multirow{4}{*}{$\begin{array}{c}\text { Clements \& Bernard } \\
{[64]}\end{array}$} & BarChip Xtreme 72 & 12 & 799 & IV, F \\
\hline & Synmix 55 & 12 & 580 & IV, F \\
\hline & Synmix 75 & 12 & 584 & IV, F \\
\hline & Dramix RC65/35 & 52 & 522 & IV, E \\
\hline \multirow{4}{*}{$\begin{array}{c}\text { Papworth } \\
\text { [48] }\end{array}$} & Scanfibre 40 & 6,5 & $>200$ & $\mathrm{I} / \mathrm{II}, \mathrm{B} / \mathrm{C}$ \\
\hline & Scanfibre 40 & 7,5 & $>280$ & III, D \\
\hline & Scanfibre 40 & 9 & $>400$ & IV, E \\
\hline & Scanfibre 40 & 11,5 & $>560$ & IV, F \\
\hline \multirow{4}{*}{$\begin{array}{l}\text { Decker et al. } \\
\text { [65] }\end{array}$} & BarChip Shogun 48 & 5 & 313 & III, D \\
\hline & BarChip Shogun 48 & 6 & 355 & III, D \\
\hline & BarChip Shogun 48 & 7 & 392 & III, D \\
\hline & BarChip 54 & 5 & 352 & III, D \\
\hline \multirow{10}{*}{$\begin{array}{c}\text { Bernard } \\
{[61]}\end{array}$} & EE30/18 & 25 & 104 & $0, \mathrm{~A}$ \\
\hline & EE30/18 & 50 & 230 & $\mathrm{I} / \mathrm{II}, \mathrm{B} / \mathrm{C}$ \\
\hline & HE60/30 & 40 & 254 & I/II, B/C \\
\hline & HE60/30 & 60 & 415 & IV, E \\
\hline & HE60/35 & 30 & 241 & $\mathrm{I} / \mathrm{II}, \mathrm{B} / \mathrm{C}$ \\
\hline & HE60/35 & 40 & 340 & III, D \\
\hline & HE60/35 & 50 & 377 & III, D \\
\hline & HE45/30 & 40 & 269 & $\mathrm{I} / \mathrm{II}, \mathrm{B} / \mathrm{C}$ \\
\hline & HE45/30 & 50 & 310 & III, D \\
\hline & HE45/30 & 60 & 347 & III, D \\
\hline \multicolumn{5}{|c|}{$\begin{array}{l}\text { *Baseado nas correlações entre a tenacidade obtida em ensaios de flexão em painéis circulares, } \\
\text { TPL e o sistema de classes de rocha [48] }\end{array}$} \\
\hline \multicolumn{5}{|c|}{$\mathrm{EE}=$ Enlarged-End $($ Fibra de aço com extremidade alargada $)$} \\
\hline \multicolumn{5}{|c|}{$\mathrm{HE}=$ Hooked-End (Fibra de aço com gancho) } \\
\hline
\end{tabular}

Ding et al. [69] compararam o comportamento mecânico do concreto projetado com fibras com a aplicação do concreto com telas metálicas nas primeiras idades através dos ensaios de flexão em painéis quadrados. Até 10 horas de cura, o concreto projetado com $20 \mathrm{~kg} / \mathrm{m}^{3}$ de fibras de aço apresenta maior capacidade de absorção de energia que o concreto reforçado com malhas de aço. Por outro lado, a partir das 18 horas, o concreto com malhas soldadas passa a apresentar maior resistência residual e, consequentemente, maior tenacidade. Dessa maneira, 
somente o concreto projetado com $60 \mathrm{~kg} / \mathrm{m}^{3}$ de fibras de aço apresentou maior capacidade de absorção de energia que o concreto com malha metálica depois de um período de 30 horas de cura.

Vandewalle [70] explica que a principal vantagem de usar o reforço com fibras ao invés da aplicação com telas soldadas é a economia de tempo com instalação. A fixação das telas na rocha costuma demandar mão de obra especializada e apresentar altos custos para a obra. Além disso, o concreto projetado com fibras costuma ser mais eficiente em preencher os vazios deixados pelo posicionamento da tela, como mostrado na Figura 18.

Yang et al. [71] buscaram novos tipos de fibras para o uso de concreto projetado em obras de escavação. Nesse trabalho, comparou-se o uso de fibras metálicas com as fibras tradicionais de aço já oferecidas pelo mercado. As fibras metálicas possuíam diferentes propriedades geométricas (comprimento, diâmetro e fator de forma) e materiais (módulo de elasticidade e resistência à tração). As fibras de aço apresentaram maiores valores de tenacidade e resistência residual em relação às fibras metálicas. Os resultados mecânicos foram obtidos a partir de ensaios de flexão em painéis quadrados (EFNARC [19]). Dessa maneira, o trabalho de Yang et al. [71] concluem que as fibras metálicas ainda não podem ser usadas em obras de contenção pós-escavação.

Um dos principais problemas que afetam o comportamento mecânico do concreto projetado em obras de mineração é a reflexão [22], já que a reflexão pode comprometer o dimensionamento realizado previamente. Kaufmann et al. [72] mostraram que as fibras de aço apresentam maior reflexão quando comparado com as fibras poliméricas devido a seu maior módulo de elasticidade e densidade. Além disso, as fibras poliméricas, devido às suas propriedades materiais, tendem a dobrar com o impacto, dissipando a energia cinética desenvolvida com a projeção. A reflexão está diretamente relacionada com as propriedades do concreto no estado fresco [22], que costuma ser modificada através de adições minerais como sílica ativa e metacaulim, por exemplo. 


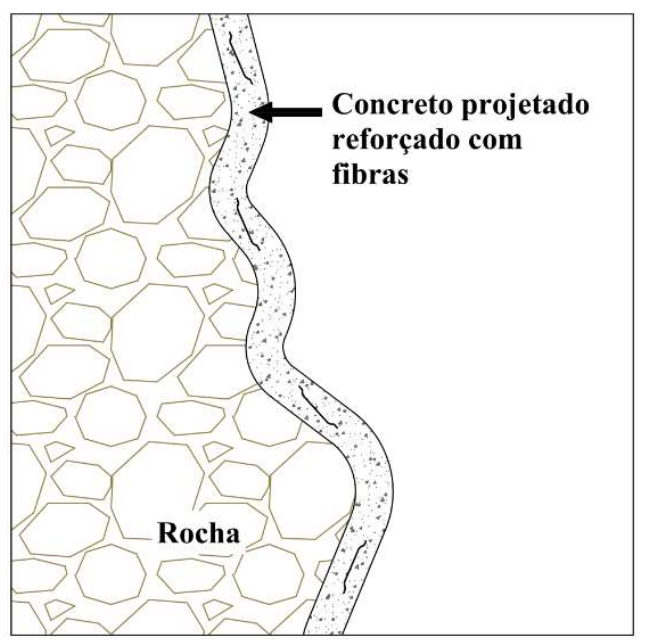

(a)

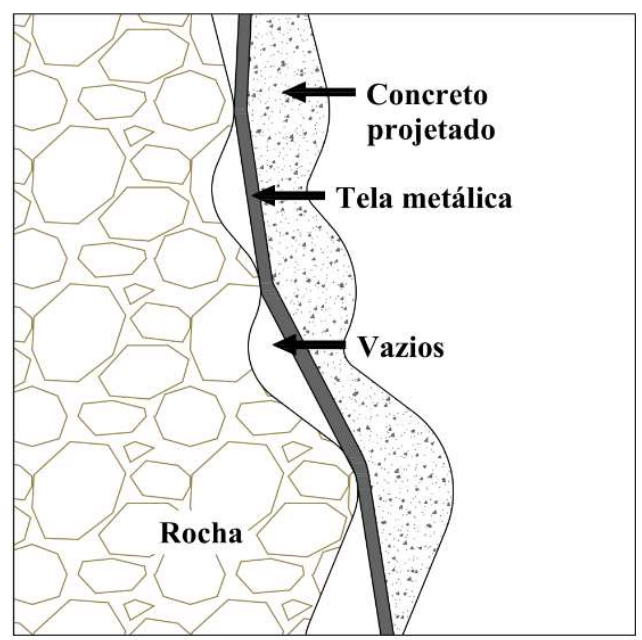

(b)

Figura 18 - Comparação entre a aplicação de (a) concreto projetado com fibras e (b) concreto projetado com tela metálica. Adaptado de Vandewalle [70]

Como mostrado anteriormente, os ensaios de flexão em painéis, baseado nas normas ASTM C1550 [46] e na EFNARC [19], são uma ferramenta importante para comparar a performance relativa do concreto projetado com fibras visando o dimensionamento do sistema de suporte. Diferentes ensaios de flexão em larga escala, por outro lado, vêm sendo desenvolvidos com o objetivo de melhor replicar as condições observadas nas obras de escavação, como:

- Configuração geométrica da amostra;

- Aderência entre o concreto projetado e a superfície da rocha;

- Condições de contorno;

- Espessura do concreto.

Fernandez Delgado et al. [10], por exemplo, testaram três diferentes arranjos experimentais para os ensaios mecânicos em concreto projetado. $\mathrm{O}$ primeiro consistiu em uma superfície plana com aplicação de carga no centro da amostra. Já a segunda configuração simulava um perfil de escavação em formato de arco com o centro plano. O terceiro arranjo, por fim, simulava um perfil de escavação irregular após detonação. As três configurações podem ser observadas na Figura 19. A partir dos ensaios realizados, foi possível observar dois modos de falha no concreto que são a perda de aderência e a ruptura por cisalhamento. Resultado semelhante também foi observado pelos experimentos de Holmgren [73]. Ao 
aplicar a contenção com os tirantes, o principal modo de falha foi a ruptura por flexão do concreto projetado. Os modos de falha são apresentados na Figura 20.

Martin et al. [37] e Raffaldi et al. [36] desenvolveram um sistema para ensaios em larga escala em amostras de concreto projetado com fibras, tirantes e telas de aço soldadas. Para a realização do ensaio mecânico os painéis foram conectados através de seus tirantes em quatro colunas de concreto, enquanto o carregamento ocorre no centro do painel. Raffaldi et al. [36] estudaram a comparação entre concreto projetado com fibras sintéticas, tela soldada e tirantes. Baseado nos seus resultados, o uso de tela soldada e tirantes apenas serviu para conter a queda dos blocos de rocha, já que a tela não promove a mesma rigidez inicial do concreto. Já a combinação de concreto projetado com fibras e tela apresentou altos valores de tenacidade e grande capacidade de absorção de energia do sistema de suporte. A Figura 21 mostra o setup utilizado.

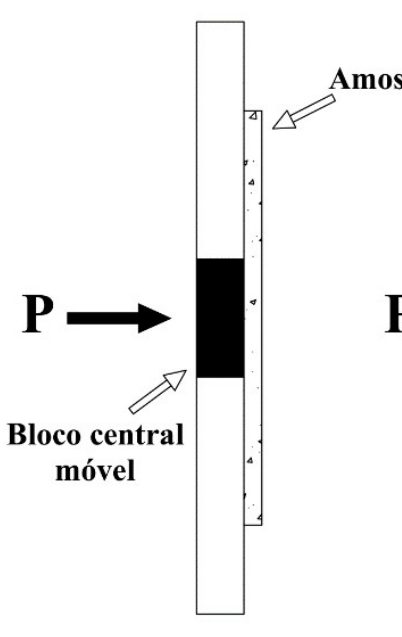

(a)

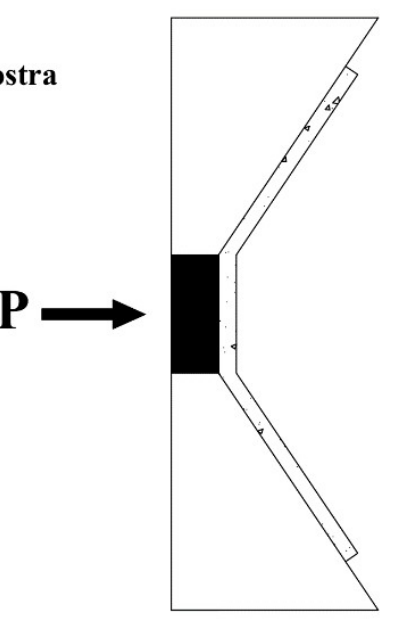

(b)

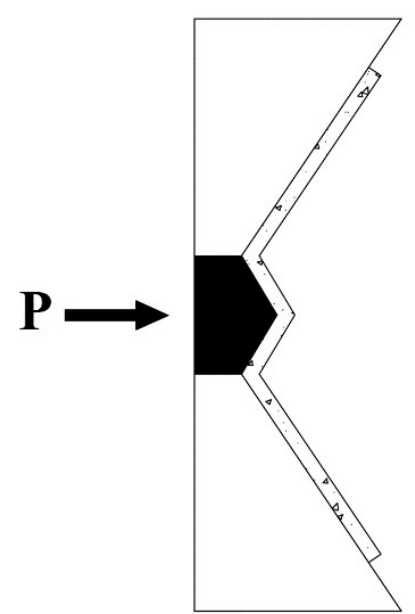

(c)

Figura 19 - Configurações de setup propostos por Fernandez Delgado et al [10]: (a) plana, (b) em formato de arco e (c) arco com centro irregular. Adaptado de Fernandez Delgado et al [10]) 

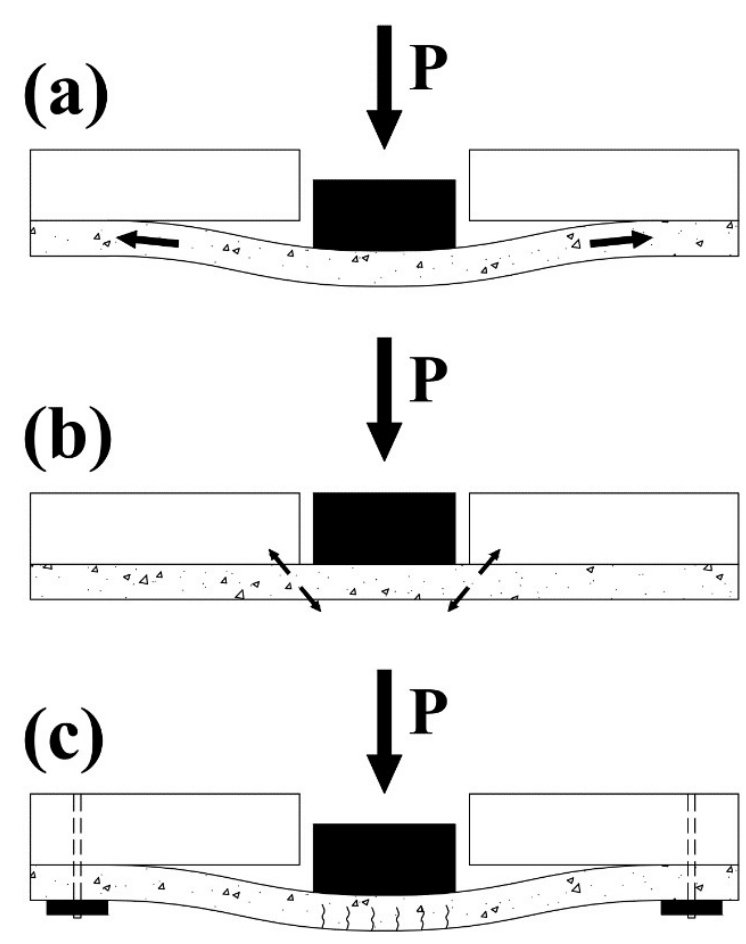

Figura 20 - Modos de falha observados por Fernandez Delgado et al [10]: (a) perda de aderência, (b) ruptura por cisalhamento e (c) ruptura por flexão. Adaptado de Fernandez Delgado et al. [10]

Por fim, Morton [13] realizou ensaios de flexão em painéis quadrados de larga escala, nos quais o concreto com fibras de aço foi projetado em uma amostra de arenito previamente entalhado em seu centro. Os ensaios foram realizados em um apoio contínuo similar ao utilizado pela EFNARC [19] em diferentes idades e diferentes espessuras. Através dos ensaios foi possível verificar tanto o comportamento mecânico da combinação entre concreto projetado com a rocha como a perda de aderência do material ao longo dos deslocamentos. Maiores espessuras e maiores idades do concreto projetado promoveram uma maior capacidade de deformação e tenacidade. A Figura 22 mostra o arranjo experimental do ensaio. 


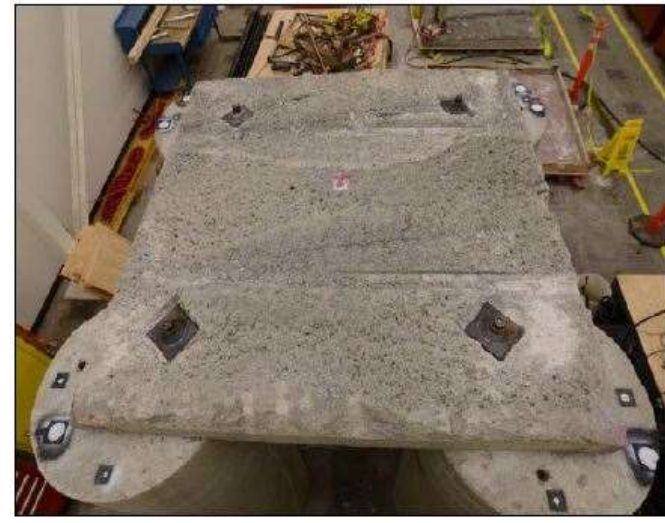

(a)

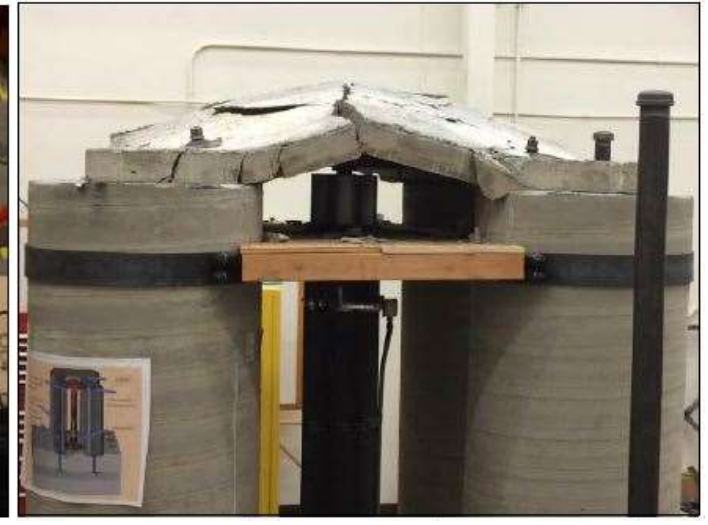

(b)

Figura 21 - Arranjo experimental desenvolvido por Martin et al. [37] para ensaios de flexão em larga escala em concreto projetado em combinação com tirantes e tela soldada: (a) antes e (b) depois da realização do ensaio.

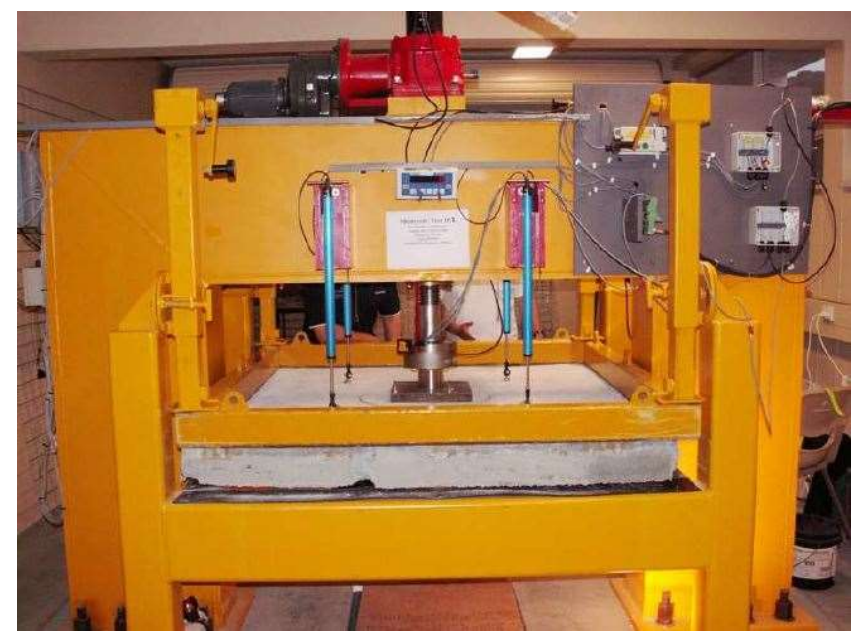

Figura 22 - Arranjo experimental usado por Morton [13] para ensaios de flexão em larga escala.

Apesar de já haver vários trabalhos estudando o comportamento mecânico do concreto projetado com fibras através dos ensaios de painel, ainda há uma lacuna de conhecimento em relação a associação entre os resultados mecânicos e o dimensionamento do sistema de suporte. Dessa maneira, o presente trabalho tem como objetivo aplicar o conhecimento sobre concreto projetado reforçado com fibras visando o dimensionamento do sistema de suporte nas obras de escavação da mina Cuiabá. 


\section{6.}

\section{Ensaio de duplo puncionamento (Barcelona)}

\subsection{1.}

\section{Configuração e aplicação}

O ensaio de duplo puncionamento foi idealizado por Chen [74] com o objetivo de medir a resistência à tração de forma indireta. Baseado no trabalho de Chen [74], Saludes [75] propôs o ensaio de Barcelona para a medida de tenacidade do concreto reforçado com fibras. Em seguida, o ensaio foi normatizado na Espanha através da UNE 83515 [76], que avalia o comportamento pós-fissuração do concreto com fibras em corpos de prova cilíndricos submetidos a um duplo puncionamento.

O puncionamento é feito através de dois discos de carga centrados nas superfícies superior e inferior do cilindro em corpos de prova cilíndricos de diâmetro igual a altura. $\mathrm{O}$ ensaio de Barcelona pode ser analisado na Figura 23. A proporção entre a altura do disco de carga e a altura da amostra é de 1:5, enquanto a razão entre os diâmetros é de 1:4. A norma espanhola estabelece que sejam utilizados diâmetros de $150 \mathrm{~mm}$ para corpos de prova moldados ou no mínimo 100 mm para testemunhos extraídos, mantendo a relação entre o diâmetro (D) e a altura (H) igual a um. Ao aplicar a carga, são induzidas tensões de tração nos planos perpendiculares ao eixo do cilindro, com o aparecimento mais comum de três fissuras. Na configuração original do ensaio de Barcelona proposta pela norma espanhola UNE 83515 [76] devem ser medidos a carga aplicada e o correspondente aumento de perímetro circunferencial (TCOD) através de um extensômetro circunferencial (Figura 23).

Pujadas [77] explica que a ruptura da amostra durante o ensaio de Barcelona ocorre em três estágios: uma primeira fase elástica linear, seguida de uma transição e, por fim, uma fase de resistência residual. Os três estágios podem ser analisados na Figura 24.

O primeiro estágio ocorre quando se inicia o carregamento com a acomodação dos discos nas superfícies do corpo de prova até que a resistência à tração da matriz seja atingida. O segundo estágio é iniciado de forma abrupta, com a formação das fissuras principais e das cunhas cônicas logo abaixo dos discos de carga. Por fim, com as principais fissuras formadas e estabilizadas, se inicia a ação 
das fibras conferindo a resistência residual à medida que as cunhas deslizam para o interior da amostra. A Figura 25 mostra o gráfico típico do ensaio de Barcelona separado pelos diferentes estágios. Baseado no modo de ruptura explicado, Blanco et al. [78] propuseram um modelo constitutivo simplificado para o uso do ensaio em guias e normas de dimensionamento.

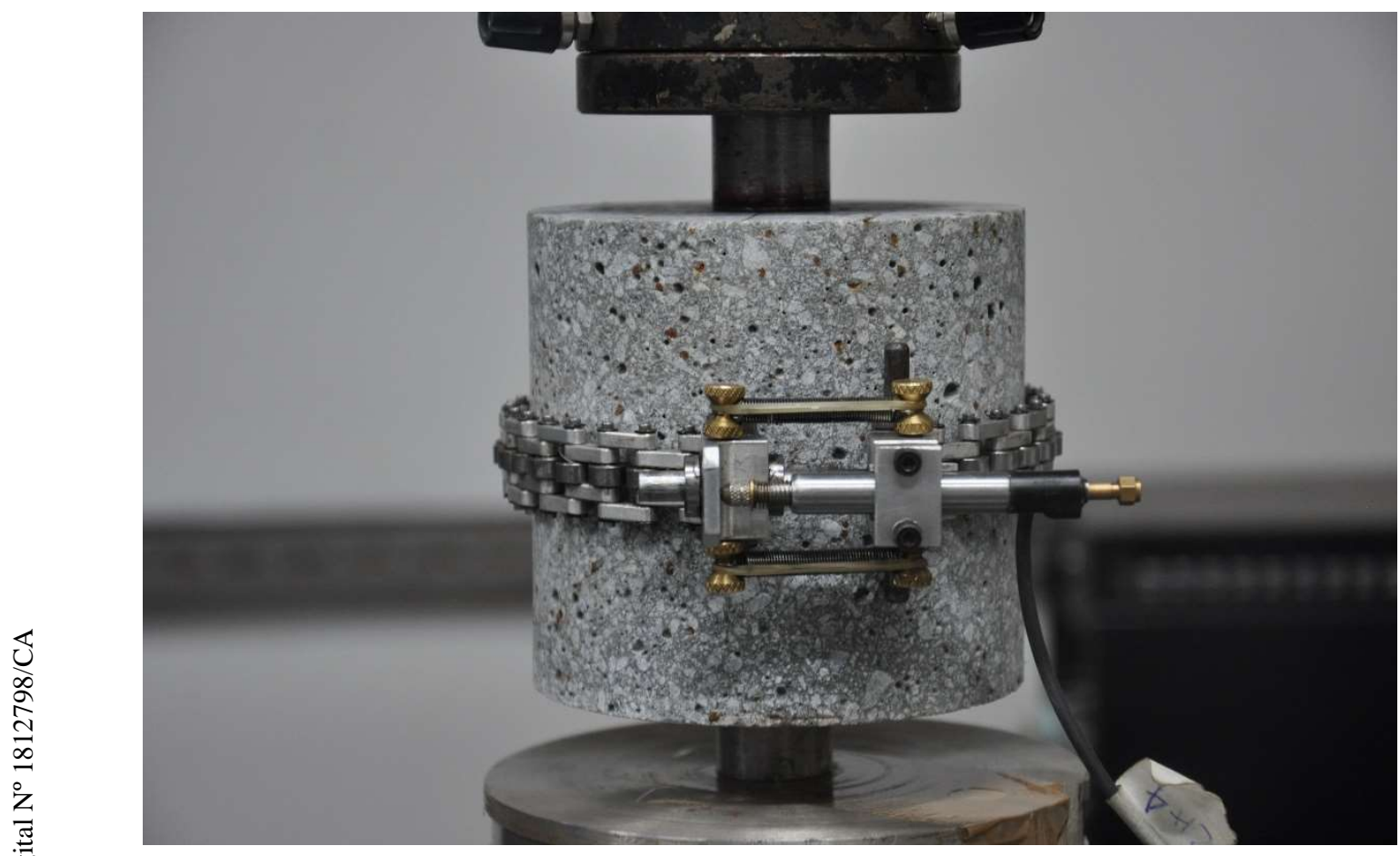

Figura 23 - Configuração do ensaio de duplo puncionamento

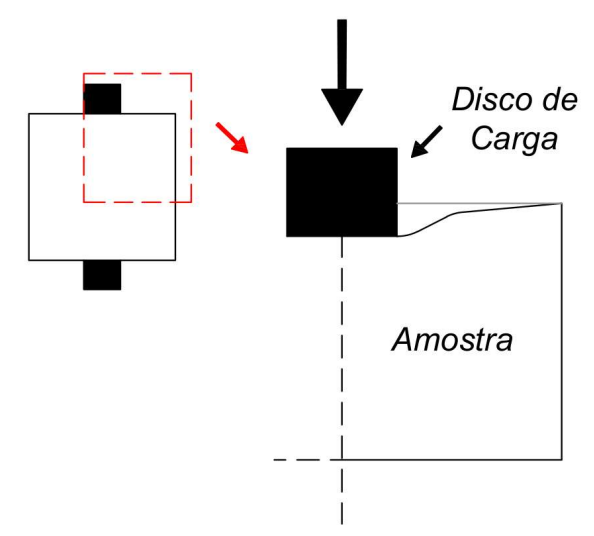

Estágio I

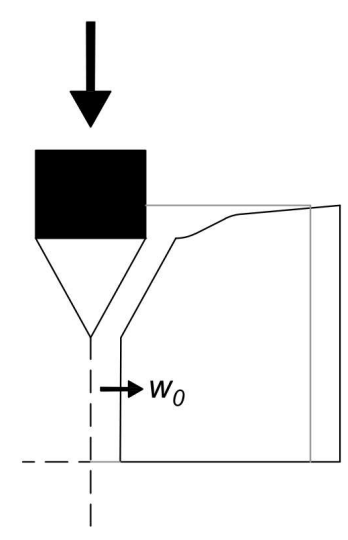

Estágio II

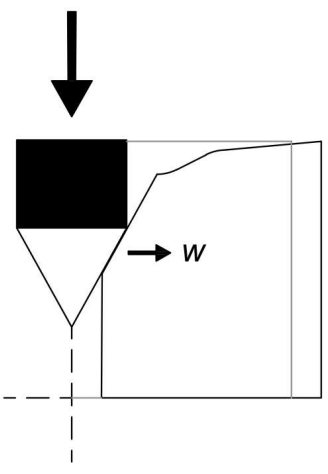

Estágio III

Figura 24 - Diferentes estágio da falha de uma amostra durante o ensaio de Barcelona. Adaptado de Pujadas [77] 


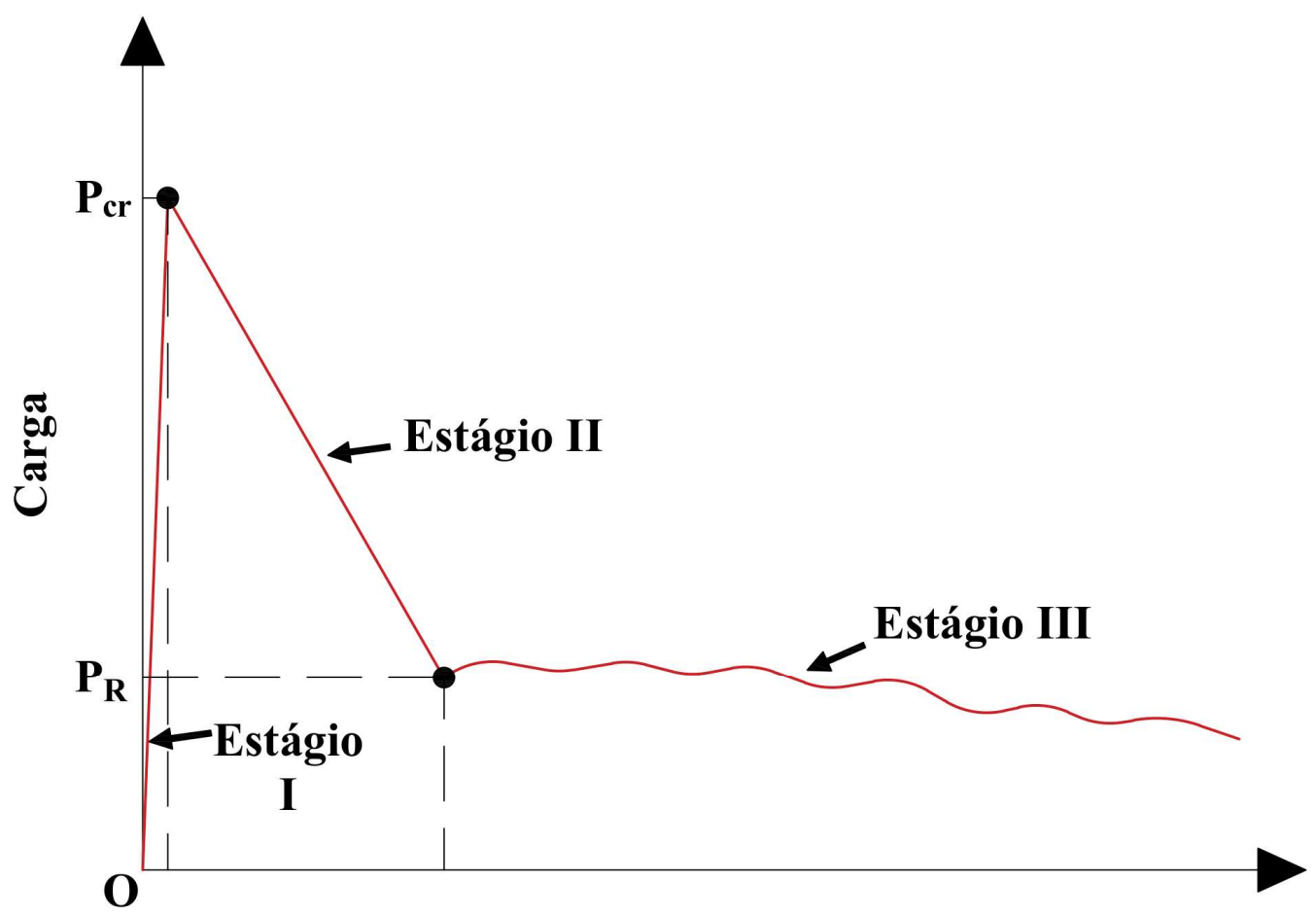

TCOD

Figura 25 - Curva típica obtida após o ensaio de Barcelona dividia nos estágios I,II e III. Adaptado de Pujadas [77]

Rambo et al. [79], por sua vez, já utilizaram o ensaio de duplo puncionamento com o objetivo de estudar o efeito da temperatura no concreto reforçado com fibras sintéticas. Baseado nos resultados obtidos, o efeito do aumento da temperatura no comportamento mecânico foi muito semelhante ao já observado no concreto convencional com relação a perda de resistência e diminuição do módulo de elasticidade. Além disso, com a perda de resistência residual e capacidade de deformação em temperaturas elevadas, houve uma perda significativa de capacidade de absorção de energia do material.

\subsection{2.}

\section{Correlação entre o ensaio de Barcelona e o ensaio de flexão em prismas}

Apesar do ensaio de tração direta ser considerado o mais apropriado para determinar as propriedades mecânicas de materiais frágeis, uma norma ainda não foi desenvolvida para materiais cimentícios. Seus resultados exibem uma grande variação devido às imperfeições dos corpos de prova e às excentricidades durante o carregamento. Além disso, o comportamento mecânico difere consideravelmente 
dependendo da geometria da amostra e suas condições de contorno, que abrange desde amostras com formato de dogbone até prismas com e sem entalhes [80-82].

Devido a esses reveses experimentais, o controle de qualidade do concreto com fibras é determinado através de ensaios de flexão em três pontos em prisma ou ensaios de flexão em quatro pontos, baseado nas normas europeia [54] e americana [52], respectivamente. Os ensaios de flexão, porém, apresentam uma grande dispersão em seus resultados, frequentemente acima de $20 \%$, que é associado com a pequena superfície de fratura e está diretamente ligada ao número específico de fibras que atravessam a seção fissurada do CRF [83]. Além disso, o ensaio de flexão necessita um complexo arranjo experimental e as amostras relativamente pesadas. Dessa maneira, esse ensaio pode não ser o mais adequado para o controle de qualidade do material no campo de trabalho.

Dessa maneira, o ensaio de Barcelona foi proposto por Molins et al. [84] com o objetivo de obter a resistência residual e a tenacidade do concreto reforçado com fibras a partir dos resultados obtidos do gráfico de carga pelo TCOD. Esse ensaio pode ser considerado versátil, já que possibilita o uso de corpos de prova cilíndricos ou cúbicos, moldados e extraídos de estruturas pré-existentes como vigas, lajes e da frente de projeção em obras de mineração.

Apesar do CEB-FIB [55] indicar o uso de ensaios de flexão com entalhe para a análise das propriedades mecânicas do CRF, o Model Code também permite a substituição por outros ensaios desde que correlações com o ensaio de referência sejam estabelecidas. Dessa maneira, diversos trabalhos desenvolveram correlações entre ensaios de flexão e o ensaio de Barcelona visando um novo método para o controle tecnológico do concreto reforçado com fibras [85-89].

Carmona \& Molins [86] desenvolveram uma correlação entre o ensaio de Barcelona e o ensaio de flexão em quatro pontos (ASTM C1609 [52]) com o objetivo de realizar o controle tecnológico do concreto projetado reforçado com fibras da mina Chuquicamata, no Chile. Os parâmetros de tensão residual e tenacidade do ensaio de flexão foram calculados a partir de uma função potência com os parâmetros de entrada obtidos do ensaio de duplo puncionamento, como mostrado nas Equações 2 e 3. Os parâmetros $a, b, c$ e $d$ dependem do tipo concreto, tipo de fibra e da fração volumétrica adicionada [86]. A partir da correlação, foi possível determinar a resistência residual $f_{150}^{D}$ a partir da resistência residual do ensaio de Barcelona com erro menor que 5\% dos resultados experimentais. Por 
outro lado, as correlações para as forças residuais, em geral, não estimaram de forma precisa os valores experimentais para os primeiros níveis de abertura de fissura dos ensaios de flexão.

$$
\begin{aligned}
& T_{\text {actual }}=a E_{B C N}^{b} \\
& \frac{f_{\text {actual }}}{f_{c t, R x}}=c w^{d}
\end{aligned}
$$

Através da correlação aplicada por Carmona et al. [88] entre os ensaios de Barcelona e flexão em três pontos (EN 14651 [54]), por outro lado, um maior erro entre o modelo e os valores experimentais obtidos foi observado. O erro do modelo atinge um valor máximo de $15 \%$ tanto para tenacidade quanto para os valores de tensão residual. O erro é especialmente maior para as correlações entre tenacidades para CMOD menor que $1,0 \mathrm{~mm}$, chegando a atingir uma diferença dos valores experimentais de até $30 \%$.

Galobardes et al. [90] também propuseram uma equação para estimar os resultados de resistência residual em ensaios de prismas usando o ensaio de Barcelona visando uma nova forma para controle de qualidade do concreto projetado reforçado com fibras de aço. Essa equação utiliza tanto a energia absorvida quanto a resistência residual do ensaio de Barcelona para estimar a resistência à flexão, como mostrado na Equação (4). Para todas as frações volumétricas estudadas, foi possível obter um coeficiente de determinação $\left(\mathrm{R}^{2}\right)$ igual a 0,97 para a correlação proposta, mostrando que as estimativas se ajustam bem aos resultados experimentais.

$$
f_{\text {Rim }}=A^{*} E_{B C N, 2.5}^{\left(B / F_{B C N, 2.5}\right)}
$$

\subsection{3.}

\section{Sistemas de controle para o ensaio de duplo puncionamento}

No ensaio de duplo puncionamento, de acordo com a norma espanhola UNE 83515 [76], o controle do ensaio é realizado através deslocamento da máquina de ensaio. Dessa maneira, o resultado pode apresentar uma região de instabilidade sendo identificado por uma grande distância entre pontos após atingir resistência da matriz [91]. A Figura 26 apresenta a instabilidade pós-pico obtida nos ensaios Barcelona. As principais causas de instabilidade pós-pico em materiais cimentícios 
reforçados com fibra são a alta resistência da matriz em relação a resistência residual, a quantidade insuficiente de fibras na seção fissurada, falta de rigidez no equipamento, sistema de controle de velocidade ou método de ensaio [92].

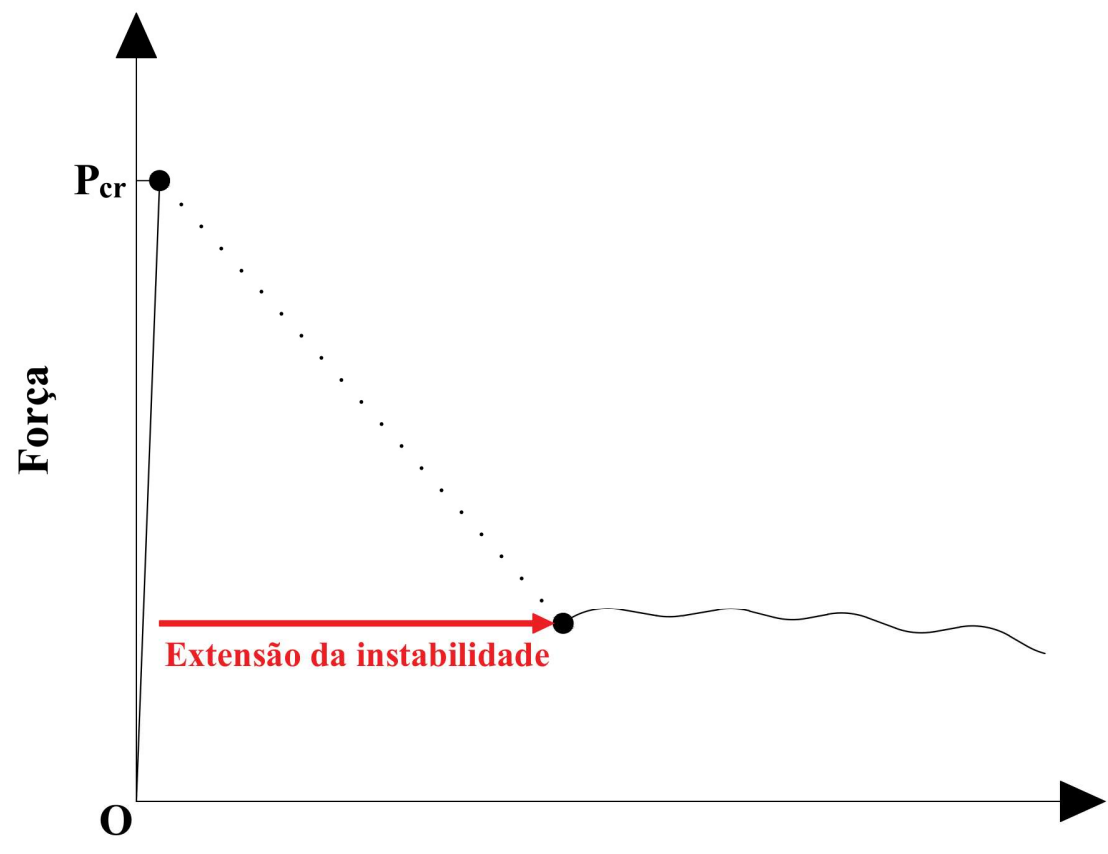

\section{TCOD}

Figura 26 - Extensão da instabilidade na curva Força por TCOD do ensaio de Barcelona. Adaptado de Simão [91]

Uma das alternativas para o controle da instabilidade é a utilização de sistemas de controle fechado (closed-loop) de deformação do corpo de prova para manter a velocidade constante durante o ensaio. Mobasher [68] define os dois tipos de controle mais usados: aberto (open-loop) e fechado (closed-loop). Através do controle aberto, a resposta do sistema não é usada pelo controlador e o processo depende somente da variável de entrada do sistema, como mostrado na Figura 27(a) e na Figura 28. Essa variável, que pode ser controlada pelo sistema, costuma ser o deslocamento do atuador e a aplicação de força (pressão). Essas duas variáveis não são afetadas significativamente pelo comportamento da amostra.

No controle do tipo fechado (closed-loop), é incorporado um mecanismo de retroalimentação (feedback), que compara o resultado da variável medida com a variável de referência na entrada. A diferença entre os dois sinais (erro calculado) é usada para manipular a posição do atuador. Dessa maneira, o escopo de uso do controle fechado é maior do que o aberto, já que uma maior variedade de variáveis 
pode ser usada no controle dos ensaios mecânicos, como a deformação radial do corpo de prova em ensaio de duplo puncionamento, o deslocamento de topo de prismas, deslocamento do atuador e a força aplicada. Ainda que a variável monitorada seja a mesma, como o controle de deslocamento do atuador, o sistema de controle fechado produz uma resposta mais precisa em relação ao controle aberto [93]. As Figuras 29 e 30 mostram o controle fechado sendo aplicado no deslocamento do atuador e pela deformação do corpo de prova.

(a)

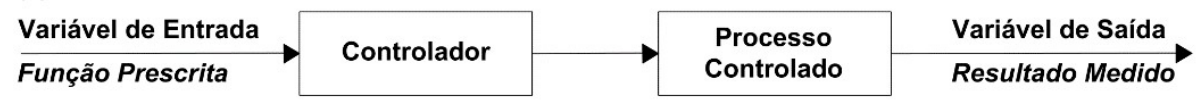

(b)

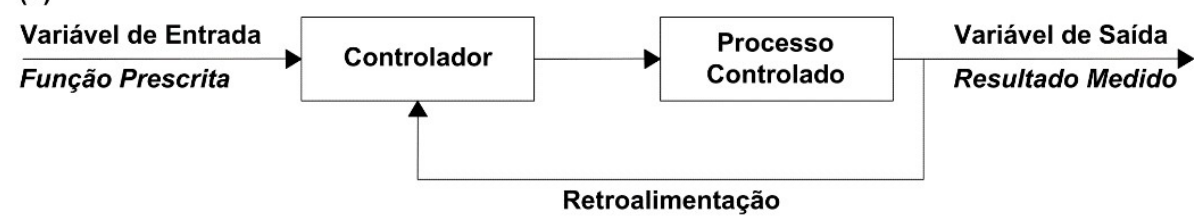

Figura 27 - Diferentes tipos de controle: (a) aberto (open-loop) e (b) fechado (closed-loop).

Adaptado de Mobasher [68]

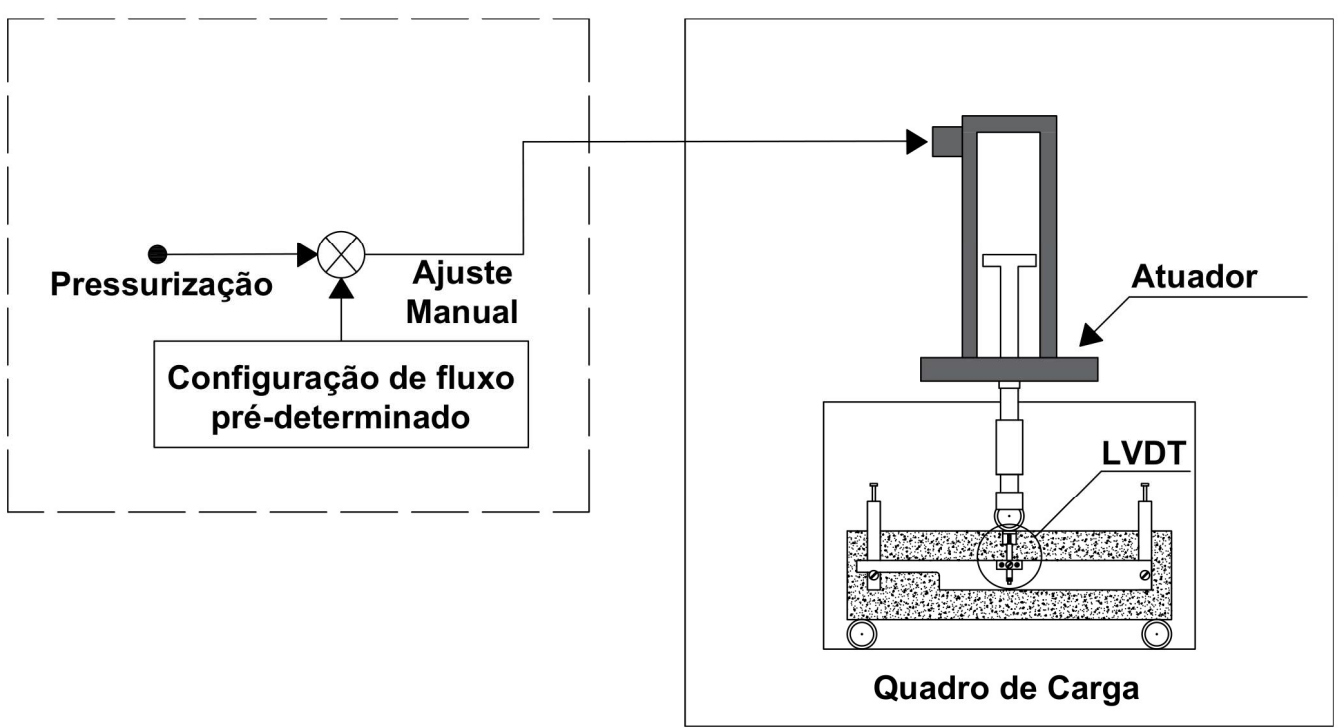

Figura 28 - Esquema de sistema aberto (open-loop) em um ensaio de flexão controlado pelo deslocamento do atuador. Adaptado de Bernard [94] 


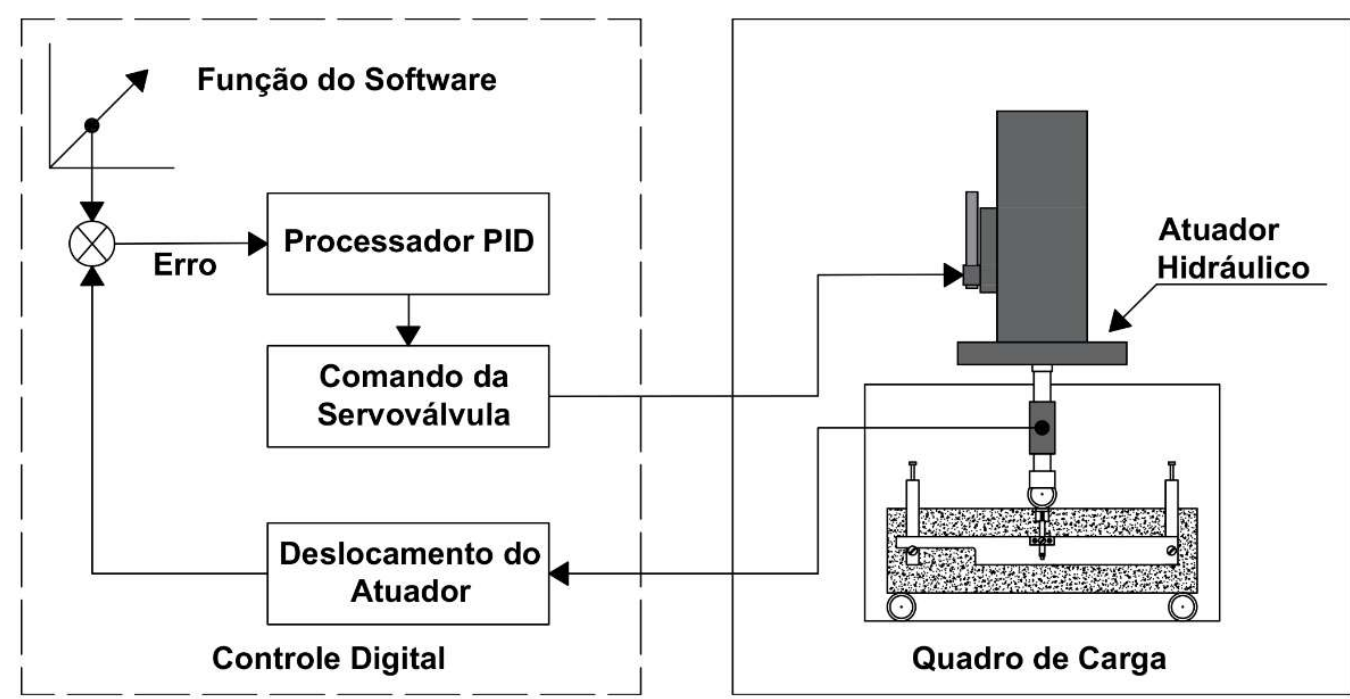

Figura 29 - Esquema de sistema fechado (closed-loop) em um ensaio de flexão controlado pelo deslocamento do atuador. Adaptado de Bernard [94]

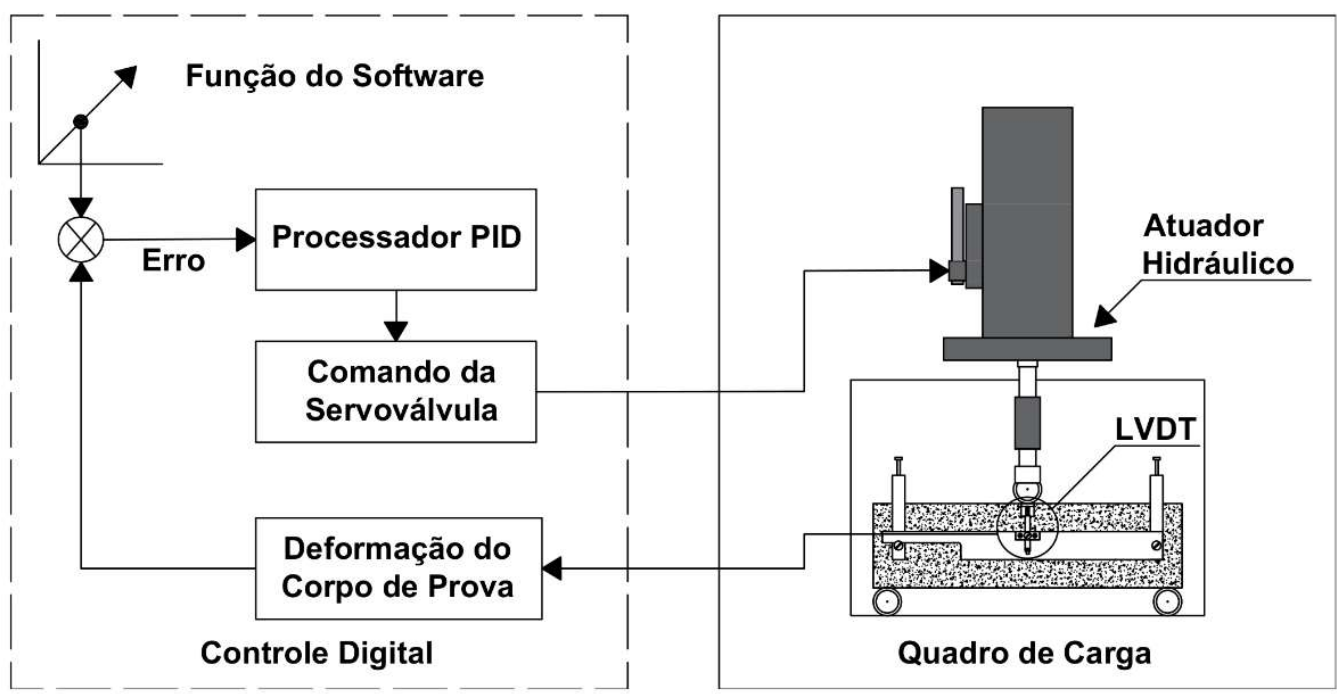

Figura 30 - Esquema de sistema fechado (closed-loop) em um ensaio de flexão controlado pelo deformação do corpo de prova. Adaptado de Bernard [94]

Banthia et al. [95] estudaram a influência do tipo de controle (aberto e fechado) nas propriedades mecânicas do concreto reforçado com fibras a partir de ensaios de flexão em prismas de acordo com a norma ASTM C1399 [126]. Através dos resultados obtidos, foi possível perceber um aumento de $40 \%$ na resistência residual média quando o controle fechado foi aplicado ao invés do controle aberto.

Simão et al. [96] analisaram a influência da instabilidade no ensaio de duplo puncionamento no comportamento mecânico pós-pico do concreto reforçado com fibras em sistemas do tipo closed-loop e open-loop. A extensão da instabilidade foi 
calculada pela razão entre $\mathrm{F}_{0,5} / \mathrm{F}_{\mathrm{CR}}$, onde $\mathrm{F}_{0,5}$ é a força residual determinada para um deslocamento vertical de $0,5 \mathrm{~mm}$ do atuador e $\mathrm{F}_{\mathrm{CR}}$ é a força de máxima atingida, associada à fissuração da matriz. Apesar do sistema fechado de controle reduzir a extensão da instabilidade pós-fissuração, não há uma diferença estatística quando comparado com os resultados obtidos com o controle do tipo open-loop. Dessa maneira, a realização dos ensaios de Barcelona em um sistema do tipo open-loop pode ser uma alternativa razoável para a análise das propriedades mecânicas do concreto reforçado com fibras.

Baseado nos trabalhos reportados, um dos principais problemas do uso do ensaio de duplo puncionamento está na instabilidade pós-pico presente quando o ensaio é controlado por controle de deslocamento. Como o ensaio de Barcelona tem como objetivo se tornar um ensaio para controle de qualidade do concreto reforçado com fibras, o presente trabalho visa estudar a influência da rigidez da máquina e do sistema de controle na instabilidade pós-fissuração e nas propriedades mecânicas do material através do ensaio de duplo puncionamento. A influência da máquina e dos tipos de controle também foi avaliada em relação às correlações com o ensaio de flexão em três pontos (EN 14651). 


\section{3}

\section{Escavação na mina Cuiabá}

\section{1. Introdução}

O capítulo 3 tem como objetivo trazer os principais aspectos geológicos e geotécnicos da mina Cuiabá, além de algumas informações sobre os sistemas de suporte usado na contenção de seu maciço rochoso. Os dados geotécnicos serão chave para o dimensionamento do concreto projetado com as diferentes frações de fibras analisadas pelo trabalho. O desenvolvimento dessa etapa baseou-se nos trabalhos realizados pelos engenheiros que trabalham atualmente na mina Cuiabá, entre outras publicações que analisaram as condições da rocha de todo o Quadrilátero Ferrífero.

\section{2. Síntese histórica}

A mina Cuiabá, de propriedade da AngloGold Ashanti, de onde se extrai o minério de ouro em lavra subterrânea, localiza-se no setor NW (noroeste) do Quadrilátero Ferrífero, no município de Sabará [97]. Foi nessa região, às margens do Rio das Velhas, onde o ouro foi encontrado em abundância pela primeira vez no Brasil, no final do século XVII [97]. Porém, segundo Libby [98], os primeiros sinais de atividade mineira no local remontam ao século XVIII, limitada praticamente à exploração aluvional, feita à flor da terra ou nos leitos dos rios, sem emprego de técnicas muito desenvolvidas. Com a exploração, os locais onde o ouro achava-se concentrado esgotaram-se rapidamente. Dessa maneira, iniciou-se a procura do ouro em camadas e veios subterrâneos, que demandavam uma tecnologia mecanizada ainda não disponível [99].

Ao longo dos anos, a região e suas minas foram exploradas por diferentes empresas estrangeiras até alcançar, em 1985, uma extração de escala industrial do minério de ouro no subsolo [100]. Em 2004, houve a fusão entre a AngloGold e a Ashanti Goldfields, resultando na atual Anglogold Ashanti, responsável pela mina 
Cuiabá. Durante a exploração da mina, foram produzidos um montante total de 156 toneladas de ouro até 2015 [100].

\section{3.}

\section{Caracterização geológica e geotécnica}

A região do Quadrilátero Ferrífero é composta por três grandes unidades litoestratigráficas: o complexo metamórfico com embasamento cristalino; sequências vulcano sedimentares e sequências plataformais do proterozoico inferior sobrepostas por coberturas sedimentares mais recentes [100], como mostrado na Figura 31 .

A mina Cuiabá encontra-se inserida na porção intermediária máfica da sequência vulcano sedimentar do tipo Greenstone Belt pertencente ao supergrupo Rio das Velhas [102]. É possível analisar o mapa geológico simplificado da mina Cuiabá na Figura 32. Segundo Toledo [103], na mina Cuiabá são observadas duas sequências diferentes: uma primeira de base composta essencialmente por metabasaltos intercalados com níveis de metapelitos carbonosos e uma camada de formação ferrífera bandada (BIF) e uma segunda sequência de topo constituída por metapelitos carbonosos com metagrauvacas compondo uma típica sequência turbidítica. Dessa maneira, as principais rochas encontradas na mina Cuiabá estão inseridas no Grupo Nova Lima que tiveram sua divisão estratigráfica apresentada na Figura 33 e resumidas a seguir:

- Metabasalto / Metandesisto (MAN);

- Formação Ferrífera Bandada (BIF);

- Filito Grafitoso (FG);

- Metabasalto (MBA);

- Clorita-quartzo-carbonato-sericita filito com matéria carbonosa (X1);

- Plagioclásio-clorita-sericita-carbonato-quartzo filito (Xs). 


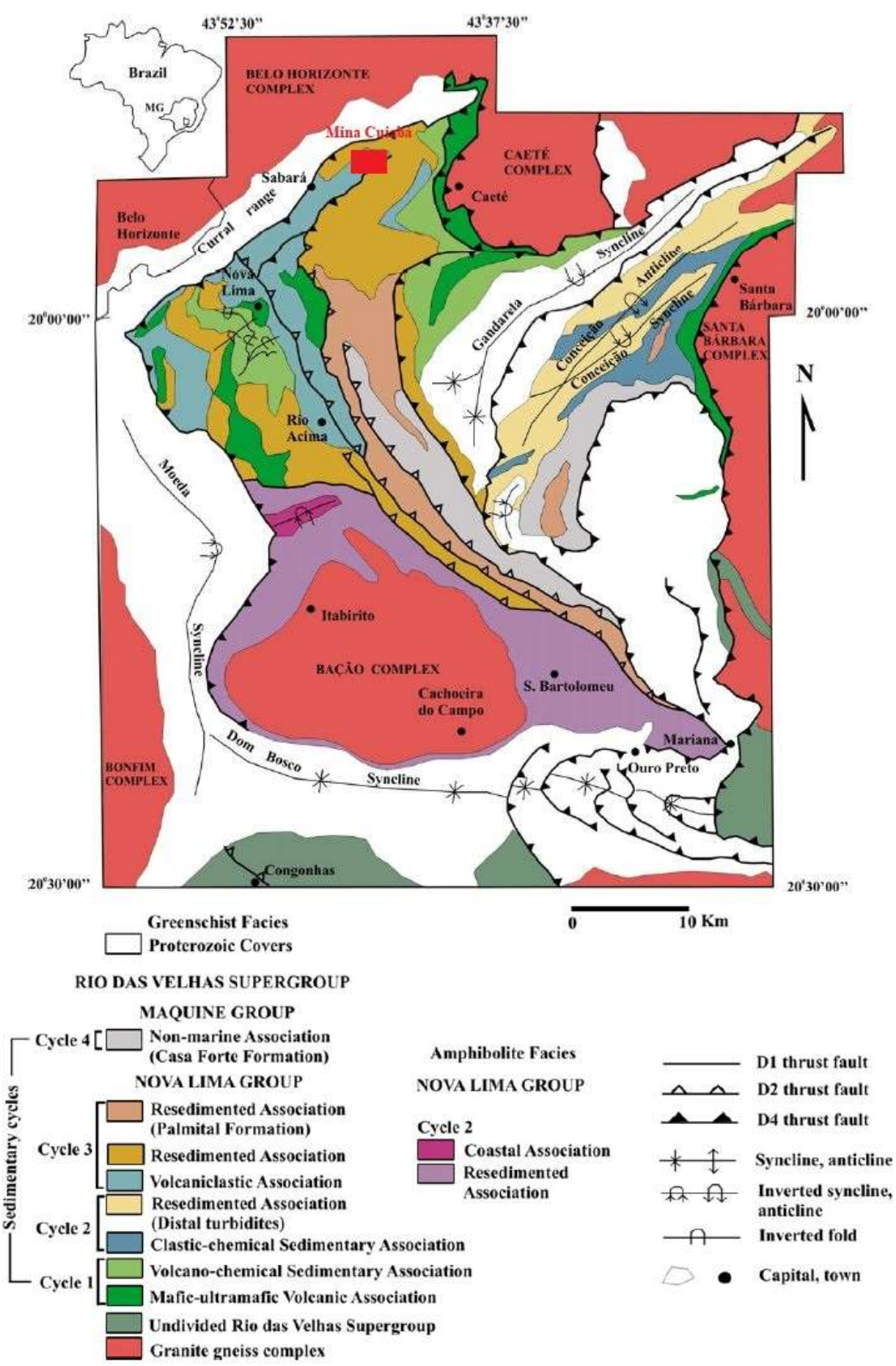

Figura 31 - Mapa geológico simplificado das principais estruturas do Rio das Velhas Greenstone Belt incluído no Quadrilátero Ferrífero. Adaptado de Baltazar \& Zuchetti [101] 


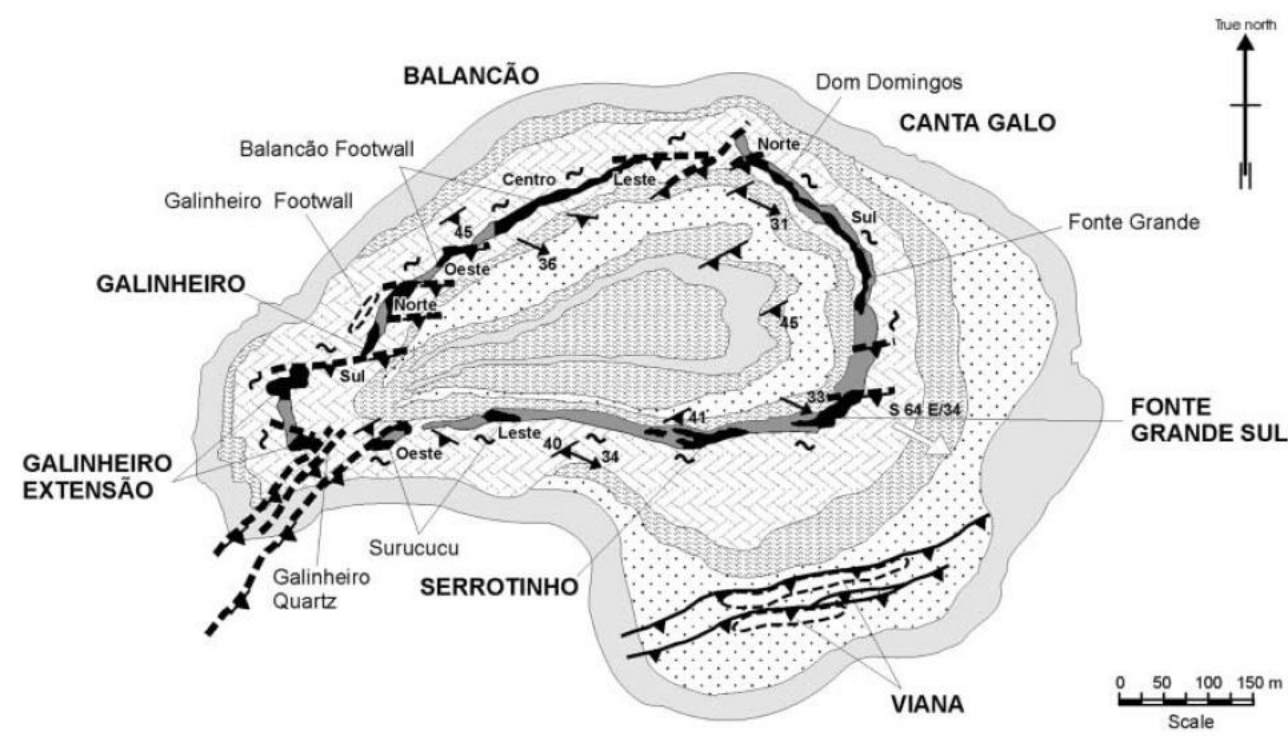

LEGEND

$\square$ Pelitic schist with intercalated volcaniclastic rocks
Basalt
Chlorite schist (distal hydrothermal alteration zone of basalt)
Carbonate-white mica schists (proximal hydrothermal alteration zones of basalt)
BIF

Figura 32 - Mapa geológico simplificado da mina Cuiabá, no nível 3, mostrando as diferentes distribuições de rocha encontradas por Lobato et al. [102]

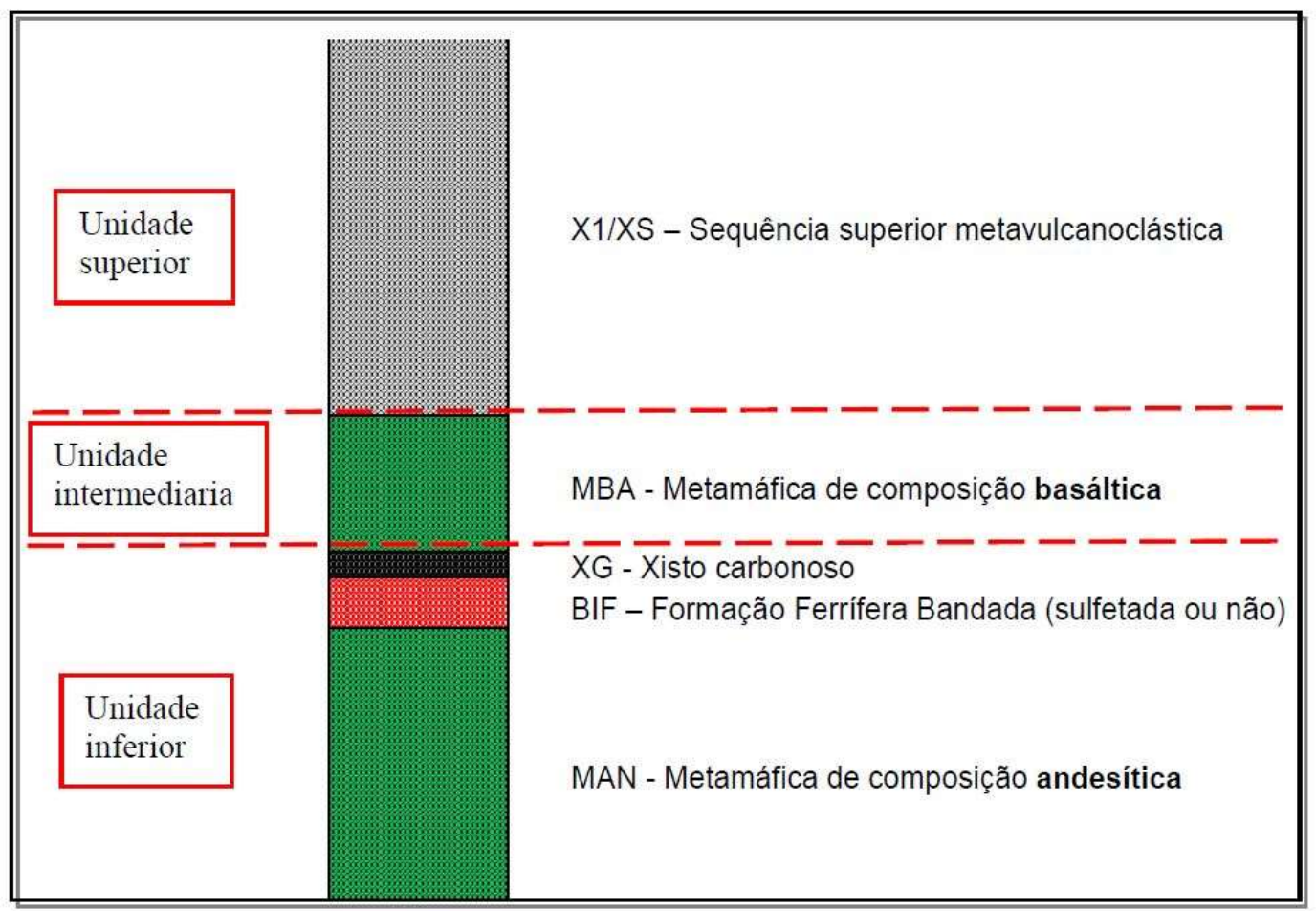

Figura 33 - Coluna estratigráfica simplificada da mina Cuiabá por Trópia [104] 
Baseado no estudo de Barbosa [97], foi possível classificar o maciço rochoso em torno do corpo Fonte Grande Sul e Serrotinho, nos níveis 9 ao 11, para os sistemas Q e RMR, além do índice de qualidade da rocha (RQD) [45]. As classificações foram feitas de acordo com as recomendações de Bieniawski [42] e Barton et al. [43] e mostradas na Tabela 7.

Tabela 7 - Classificação do maciço rochoso nos corpos Fonte Grande Sul e Serrotinho da mina

Cuiabá. Adaptado de Barbosa [97]

\begin{tabular}{cccc}
\hline Domínio & $\begin{array}{c}\text { RQD - Rock Quality } \\
\text { Designation [45] }\end{array}$ & $\begin{array}{c}\text { RMR - } \\
\text { Bieniawski [42] }\end{array}$ & $\begin{array}{c}\text { Q - Barton et } \\
\text { al. [43] }\end{array}$ \\
\hline Capa do Minério & $60-95$ & $46-65$ & $1,96-21,6$ \\
Minério & $95-100$ & $68-82$ & $6,7-40$ \\
Lapa do Minério & $75-100$ & $55-81$ & $5,6-13,1$ \\
\hline
\end{tabular}

\section{4.}

\section{Sistemas de suporte e reforço aplicados na mina Cuiabá}

O dimensionamento dos sistemas de suporte e reforço da mina Cuiabá é realizado a partir de metodologias empírica, analítica e numérica, além do conhecimento prático local dos engenheiros da unidade [100]. Para as escavações de lavra, sejam pela metodologia de corte e aterro ou sublevel stoping, o principal reforço utilizado consiste na aplicação de cordoalhas de aço com especificação de comprimento de malha. A aplicação de suporte de superfície em desenvolvimento na mina Cuiabá foi iniciada com a aplicação pontual de telas em escavações específicas como distritos, rampas e outros.

Em 2012, permitiu-se a realização de testes e aplicação por dois anos de Thyn Spray on Liners (TSL) em regiões específicas da mina, como galerias de sondagem e infraestrutura em geral [100]. Esse suporte foi substituído pelo aumento da aplicação de concreto projetado com fibras de aço, que teve início em 2007, com maiores investimentos direcionados a tal prática a partir de 2012. É esperado que uma capacidade de $86 \mathrm{~m}^{3} /$ dia de projeção de concreto com fibras na mina Cuiabá em 2020 [100].

O aumento vertiginoso de volume de concreto projetado está associado a uma evolução na ocorrência de Fall of Ground (FOG) em galerias de desenvolvimento, que pode ser definido como a queda de blocos de rocha após a escavação. É possível 
identificar um aumento das ocorrências de FOG com o aumento do ritmo de produção da mina pela metodologia de lavra chamada sublevel stoping [100, 105].

Costa et al. [106] mapearam o dano dos sistemas de suporte aplicados na rampa do Serrotinho e observaram deformações na ordem de $15 \mathrm{~cm}$ da rocha, principalmente ao atingir maiores profundidades. Além disso, monitorou-se a velocidade média de convergência das seções com o uso de extensômetros.

O sistema de suporte consistia inicialmente na aplicação de concreto projetado com tirantes, porém, com as grandes deformações presentes em grandes profundidades da mina foi necessário ajustar o suporte. Costa et al. [106] aplicaram o sistema de suporte que fosse capaz de resistir aos $15 \mathrm{~cm}$ de deslocamento do maciço rochoso. Dessa maneira, selecionou-se um sistema com concreto projetado com fibras e tela soldada para o caso analisado. O sistema de suporte antes e depois do ajuste pode ser analisado na Figura 34.

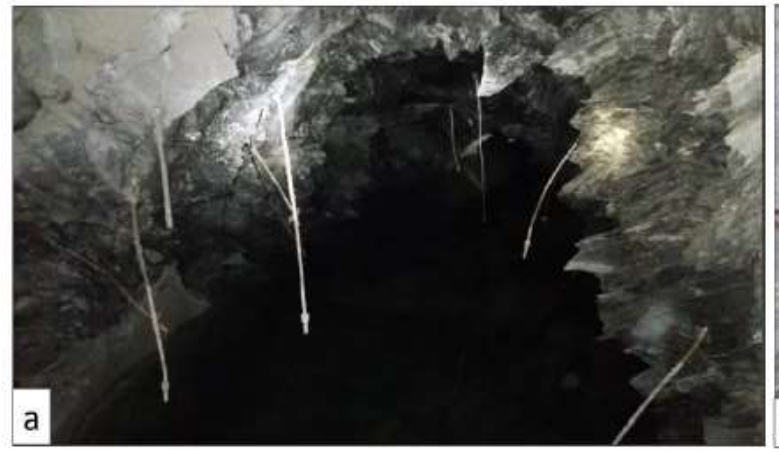

(a)

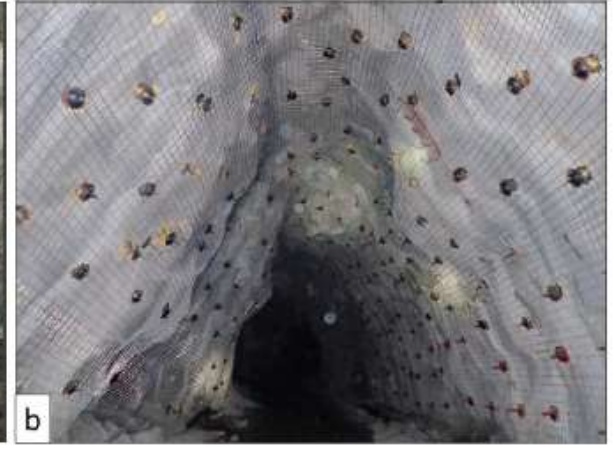

(b)

Figura 34 - Ajuste do sistema de suporte aplicado na rampa do Serrotinho por Costa et al. [106]:

(a) suporte danificado com as grande deformações rochosas e (b) sistema ajustado com concreto projetado e tela soldada.

\section{5.}

\section{Controle tecnológico do concreto projetado da mina Cuiabá}

O controle tecnológico do concreto projetado reforçado com fibras da mina Cuiabá verifica especialmente as propriedades relativas à matriz cimentícia e seus componentes como resistência à compressão, resistência à flexão, dosagem, espalhamento e quantidade de ar incorporado. Com a construção de uma nova usina de produção de concreto e as modificações do traço ao longo do tempo, foi possível observar um aumento da resistência à compressão e uma diminuição do desvio 
padrão dos resultados, que iniciou com 16,8 MPa em 2013 e apresenta, em 2017, uma resistência de 50,12 $\mathrm{MPa}$. A evolução da resistência à compressão pode ser analisada na Figura 35.

Além disso, analisa-se a resistência à compressão nas primeiras idades através da força medida com o uso de um penetrômetro e conforme a norma EN14488-2 [107]. A Figura 36 mostra a evolução da resistência à compressão do concreto projetado ao longo das primeiras horas. De acordo com a norma EN 14487-1 [108], pode-se dividir a evolução da resistência em três classes diferentes: J1, J2 e J3. A classe J1 é apropriada para aplicações com fina camadas de concreto em um substrato seco sem requisitos estruturais. A classe J2 está associada com camadas mais espessas de concreto em menor espaço de tempo e o concreto projetado de classe J3 é apropriado para casos especiais quando aplicado a rochas muito frágeis e com grande fluxo de água.

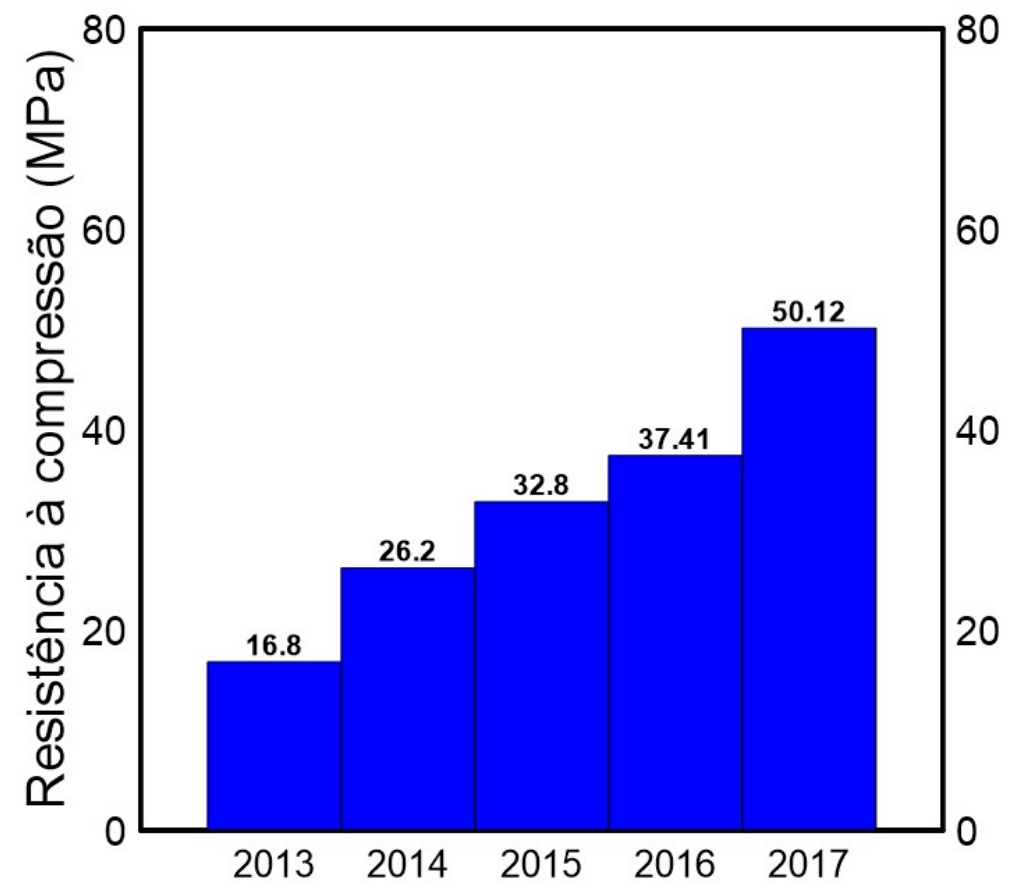

Figura 35 - Evolução da resistência à compressão do concreto projetado 


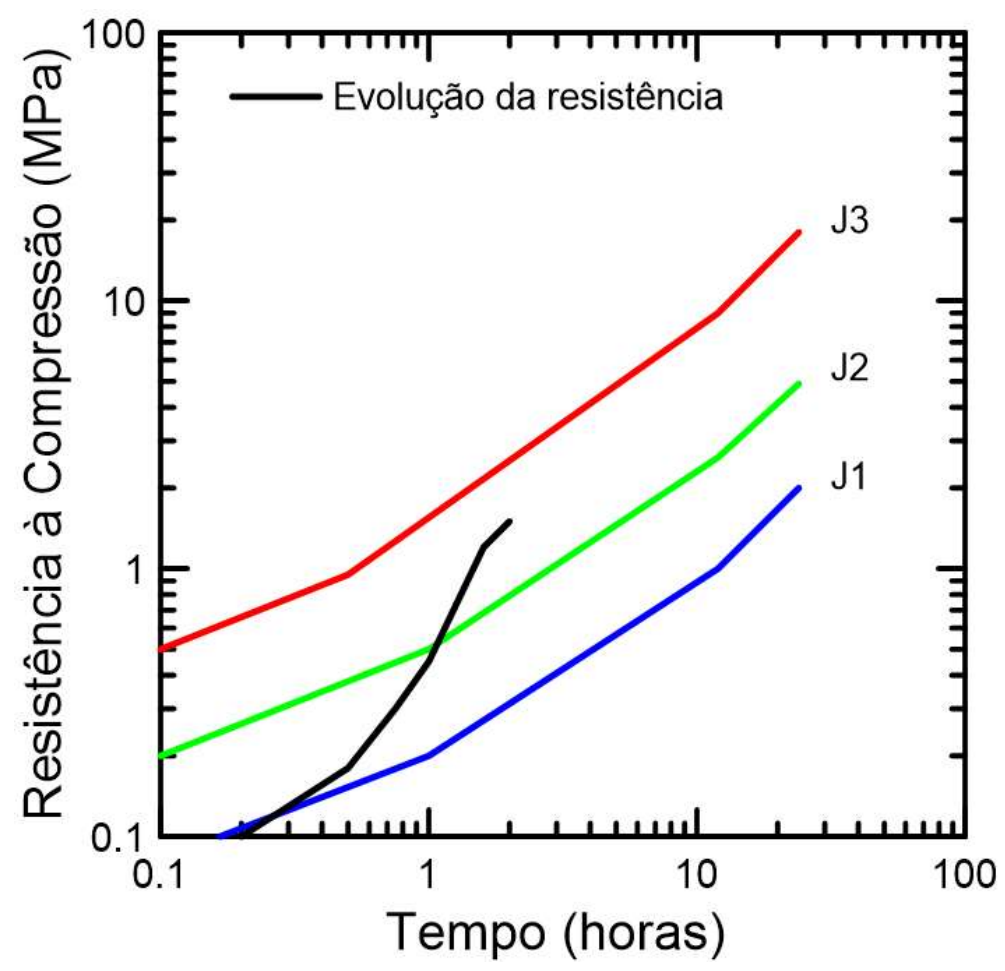

Figura 36 - Evolução do da resistência à compressão do concreto projetado nas primeiras idades

\section{6.}

\section{Fibras aplicadas na mina Cuiabá}

Incialmente, o concreto projetado da mina Cuiabá era reforçado com $25 \mathrm{~kg} / \mathrm{m}^{3}$ da fibra de aço da Belgo Bekaert Arames a fim de conter as deformações pósescavação da rocha. Porém, como o volume diário de concreto aplicado na mina aumentou significativamente até 2019, optou-se por buscar outros fornecedores no mercado com o objetivo de diminuir os custos com a compra do reforço fibroso. Dessa maneira, passou-se a usar as fibras sintéticas BarChip54 da Elasto Plastic Concrete (ELP) e, a partir de meados de 2018, mudou-se mais uma vez para fibras sintéticas TamFib SP54 da Normet. No caso das fibras sintéticas, as aplicações iniciais foram realizadas com $4,2 \mathrm{~kg} / \mathrm{m}^{3}$.

A partir do fim de 2018, com a mudança de fibras e necessitando melhor entender o comportamento mecânico do concreto projetado com fibras, amostras de painel circular foram enviadas para o Laboratório de Estruturas e Materiais da PUC-Rio. Com essa parceria, foi possível melhor entender as propriedades mecânicas do material compósito utilizado na mina. Desde então, já foi estudada a adição de maiores frações volumétricas das fibras da Normet $\left(6\right.$ e $\left.8 \mathrm{~kg} / \mathrm{m}^{3}\right)$ através 
dos ensaios de flexão, devido às grandes deformações do maciço rochoso presentes na mina Cuiabá. 


\section{4}

\section{Caracterização dos materiais}

\section{1. Introdução}

O capítulo 4 traz a caracterização dos materiais utilizados para esse trabalho de acordo com as recomendações estabelecidas para o concreto projetado. Dois traços foram utilizados nessa pesquisa. O primeiro foi o traço utilizado para a fabricação das amostras na mina Cuiabá que contém o traço completo com todos os aditivos aceleradores e retardadores. Já o segundo é um traço adaptado para a moldagem de amostras em laboratório, mantendo o mesmo fator água/cimento e utilizando os mesmos materiais utilizados na frente de projeção. Em seguida, são descritas as etapas de moldagem das amostras fabricadas na mina Cuiabá e no laboratório. Por fim, são apresentadas as propriedades das fibras aplicadas de acordo com os catálogos fornecidos pelos fabricantes.

\section{2.}

\section{Materiais e dosagem}

O traço utilizado foi desenvolvido pela empresa AngloGold Ashanti visando a aplicação do concreto projetado com fibras para o revestimento dos túneis da mina Cuiabá. O cimento Portland de alta resistência CPV-ARI, que de acordo com a norma brasileira NBR 5733 [109] deve apresentar uma resistência de $34 \mathrm{MPa}$ aos 7 dias, foi utilizado com um fator água/cimento de 0,45 .

$\mathrm{O}$ agregado aplicado na mistura foi desenvolvido baseado nas recomendações europeias para concreto projetado, EFNARC [19]. A recomendação europeia apresenta um conjunto de curvas de distribuição granulométrica possíveis para a aplicação analisada. O agregado deve apresentar uma distribuição dentro dos limites estabelecidos pela EFNARC. A distribuição granulométrica do agregado usado foi determinada de acordo com a norma NBR NM 248 [110]. Os limites estabelecidos pela EFNARC podem ser analisados na Figura 12 e a distribuição granulométrica do agregado aplicado pode ser visualizada na Figura 37. 
Três aditivos químicos diferentes foram utilizados. $\mathrm{O}$ aditivo superplastificante aplicado foi o MasterGlenium ${ }^{\circledR}$, produzido pela fabricante BASF dentro do que estabelece a norma NBR 11768 [111]. O uso de superplastificantes tem como objetivo melhorar a trabalhabilidade do concreto utilizado, especialmente depois da adição de fibras.

O estabilizador Delvo ${ }^{\circledR}$ Crete e o acelerador MasterRoc ${ }^{\circledR}$ SA 190, ambos também produzidos pela BASF, foram incorporados na mistura. A adição de aceleradores e estabilizadores modificam o tempo de pega. Enquanto o primeiro acelera a hidratação do cimento promovendo um menor tempo de pega, o segundo estabiliza a hidratação e aumento o tempo de aplicação [112].

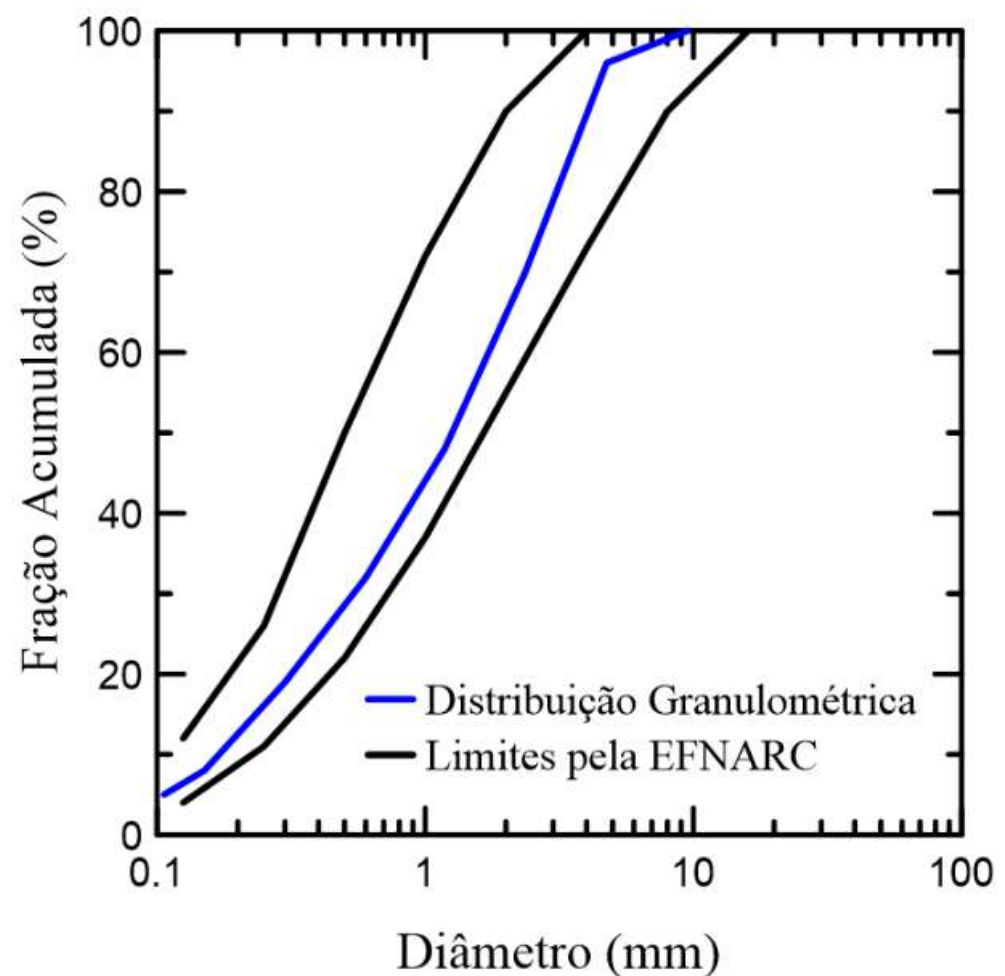

Figura 37 - Distribuição granulométrica compreendida entre os limites estabelecidos pela

EFNARC [19]

Dois traços foram utilizados para analisar o comportamento mecânico do concreto projetado ao longo do programa experimental. A primeira dosagem foi utilizada para a moldagem das amostras dentro da mina Cuiabá através de uma máquina de projeção. Nesse caso, foi utilizado o traço original desenvolvido pela empresa AngloGold Ashanti e pode ser analisado na Tabela 8. O traço aplicado na mina Cuiabá apresentou 50,12 MPa de resistência à compressão média após 28 dias em 2017 (Figura 35). 
Tabela 8 - Traço original usado para a produção de amostras na mina Cuiabá

\begin{tabular}{cc}
\hline Composição & Dosagem $\left(\mathrm{kg} / \mathrm{m}^{3}\right)$ \\
\hline Cimento & 480 \\
Água & 216 \\
Superplastificante & 3,60 \\
Estabilizador & 1,20 \\
Acelerador & 38,40 \\
Fator água/cimento & 0,45 \\
Agregado & 1530 \\
\hline
\end{tabular}

A segunda dosagem foi adaptada do original para a fabricação das amostras no Laboratório de Estruturas e Materiais da PUC-Rio (LEM-DEC). A dosagem de superplastificante foi reduzida visando uma trabalhabilidade compatível para as moldagens em laboratório. O segundo traço pode ser visualizado na Tabela 9. Não foram utilizados aceleradores e estabilizadores para a moldagem em laboratório. A quantidade de cimento foi modificada visando alcançar a mesma resistência à compressão da matriz da mina Cuiabá, porém, mantendo o mesmo fator água/cimento.

Ensaios de compressão foram realizados de acordo com a norma NBR 5739 [113] com o objetivo de obter a resistência à compressão da matriz. Três corpos de prova de $200 \mathrm{~mm}$ de altura e $100 \mathrm{~mm}$ de diâmetro foram moldados e ensaiados após 28 dias de idade. Os ensaios foram realizados em uma máquina de ensaios mecânicos da fabricante Controls, modelo MCC8, servo-controlada com capacidade de $2000 \mathrm{kN}$ e velocidade de carregamento de $0,35 \mathrm{MPa} / \mathrm{s}$. A resistência à compressão obtida da matriz aos 28 dias foi de 49,35 \pm 5,09 MPa.

Vale ressaltar que os mesmos materiais foram utilizados para os dois traços executados, já que o agregado, o cimento e o superplastificante foram enviados da mina Cuiabá para a Laboratório de Estruturas e Materiais da PUC-Rio.

Tabela 9 - Traço adaptado usado para a produção de amostras no laboratório

\begin{tabular}{cc}
\hline Composição & Dosagem $\left(\mathrm{kg} / \mathrm{m}^{3}\right)$ \\
\hline Cimento & 515 \\
Água & 231,75 \\
Superplastificante & 0,77 \\
Fator água/cimento & 0,45 \\
Agregado & 1530 \\
\hline
\end{tabular}




\section{3.}

\section{Procedimento de mistura}

\subsection{1.}

\section{Moldagem em laboratório}

As misturas acima de 30 litros foram realizadas em uma betoneira com capacidade para 400 litros. As misturas de até 30 litros foram executadas em um misturador planetário de 30 litros. As moldagens de até 5 litros foram produzidas em um misturador da marca Contenco com capacidade de 5 litros. O seguinte procedimento foi cumprido durante o processo de mistura:

- O agregado foi adicionado ao tambor de mistura (previamente saturado) com cerca de $70 \%$ da água e misturado por 1 minuto;

- Em seguida, o cimento foi lançado e misturado com o resto dos materiais por mais 1 minuto;

- Após a mistura do cimento, o superplastificante foi lentamente adicionado com os $30 \%$ restantes de água e a mistura continuou por mais 5 minutos.

- Caso o traço analisado apresentasse fibras, elas foram adicionadas e misturadas por mais 5 minutos.

A Figura 38 resume o procedimento de mistura usado nas moldagens realizadas em laboratório.

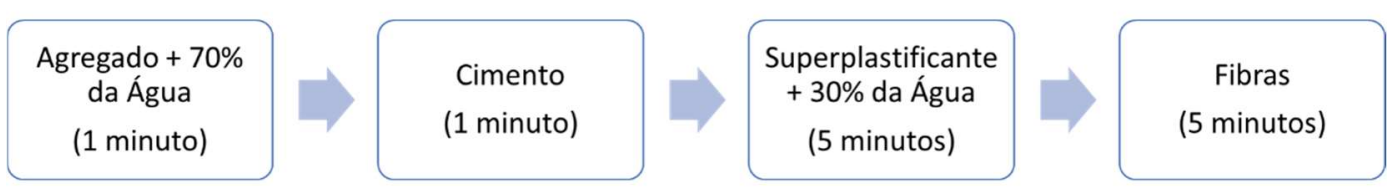

Figura 38 - Procedimento de mistura realizado em laboratório

\subsection{2.}

\section{Moldagem na mina Cuiabá}

A mina Cuiabá possui uma central dosadora de concreto que mistura os materiais e distribui o concreto para as frentes de projeção. A distribuição do concreto é feita através de caminhões betoneira. A Figura 39 mostra a central e o caminhão betoneira usados na mina. 


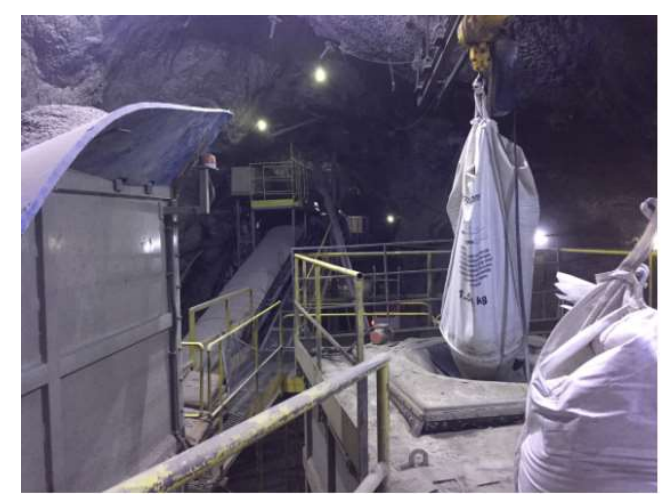

(a)

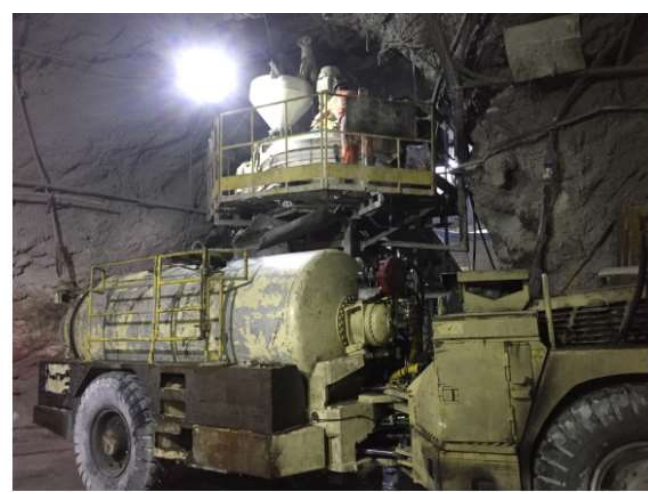

(b)

Figura 39 - Processo de mistura na mina Cuiabá: (a) central de concreto dentro da mina Cuiabá.

(b) caminhão betoneira.

O concreto é projetado na mina através de um robô de projeção, que também foi utilizado para a moldagem das amostras enviadas para o Laboratório de Estruturas e Materiais da PUC-Rio (LEM-DEC). A Figura 40 mostra o robô de projeção sendo utilizado para a projeção de concreto após a escavação do túnel dentro da mina.

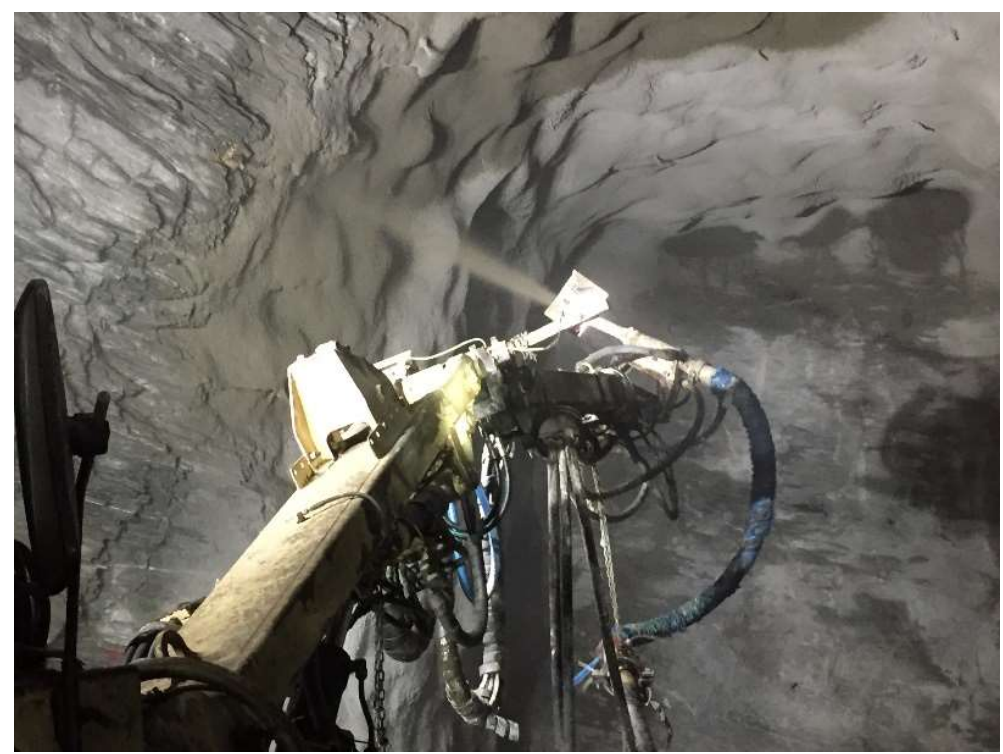

Figura 40 - Robô de projeção usado para a moldagem das amostras

4.4.

Fibras

As fibras de polipropileno utilizadas nesse trabalho são fabricadas por duas empresas diferentes: Elasto Plastic Concrete ${ }^{\circledR}$ e Normet ${ }^{\circledR}$. A fibra da Elasto Plastic Concrete utilizada foi a BarChip54 e no caso da Normet foi a TamFib SP54. As 
duas macrofibras sintéticas são produzidas visando o mercado de concreto projetado. As principais características dessas macrofibras segundo informações fornecidas pelos fabricantes estão indicadas na Tabela 10, com exceção do diâmetro que foi obtido através do microscópio estereoscópio da marca Nikon (SMZ800N). Com o microscópio, mediu-se a área da seção transversal das fibras e, em seguida, obteve-se o diâmetro equivalente. A razão de aspecto foi calculada a partir da divisão do comprimento pelo diâmetro equivalente da cada fibra. A Figura 41 apresenta as três fibras estudadas.

Tabela 10 - Características das fibras sintéticas de acordo com seus respectivos fabricantes

\begin{tabular}{ccc}
\hline Características & BarChip54 & TamFib SP54 \\
\hline Fabricante & Elasto Plastic Concrete & Normet \\
Densidade $\left(\mathrm{g} / \mathrm{cm}^{3}\right)$ & 0,90 & 0,91 \\
Comprimento $(\mathrm{mm})$ & 54 & 54 \\
Diâmetro Equivalente $(\mathrm{mm})$ & $0,92 \pm 0,03$ & $0,87 \pm 0,04$ \\
Razão de Aspecto $(\mathrm{l} / \mathrm{d})$ & 59 & 62 \\
Resistência à Tração $(\mathrm{MPa})$ & 640 & 450 \\
Módulo de Elasticidade $(\mathrm{GPa})$ & 12 & 7 \\
Ancoragem & Alto Relevo & Alto Relevo \\
\hline
\end{tabular}

As fibras de aço, por sua vez, são fabricadas pela Belgo Bekaert Arames ${ }^{\circledR}$. O comprimento da fibra de aço é de $35 \mathrm{~mm}$ com um fator de forma de 65 . As fibras usadas são da família Dramix 3D, apresentando uma ancoragem mecânica com a presença dos ganchos em suas extremidades. As características da fibra de aço, de acordo com o fabricante, podem ser analisadas na Tabela 11. As fibras de aço aplicadas nesse trabalho nessa pesquisa atendem aos requisitos estabelecidos pela EFNARC [19]. 
Tabela 11 - Características das fibras de aço de acordo com seu fabricante

\begin{tabular}{cc}
\hline Características & Dramix \\
\hline Fabricante & Belgo Bekaert Arames \\
Família & $3 \mathrm{D}$ \\
Comprimento $(\mathrm{mm})$ & 35 \\
Diâmetro $(\mathrm{mm})$ & 0,55 \\
Fator de Forma & 65 \\
Resistência à Tração $(\mathrm{MPa})$ & 1345 \\
Módulo de Elasticidade $(\mathrm{GPa})$ & 210 \\
\hline
\end{tabular}

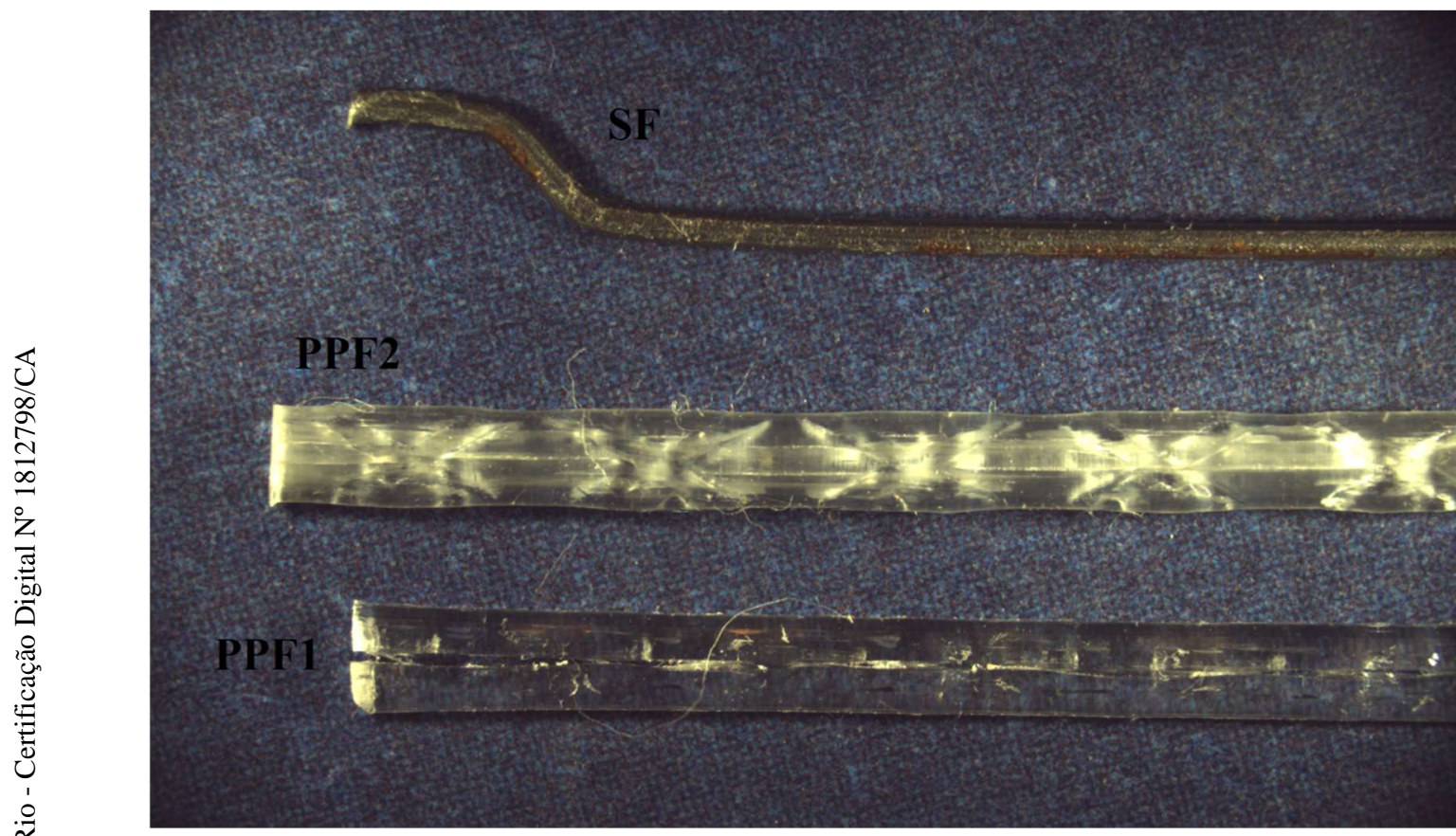

Figura 41 - Fibras de aço e sintéticas estudadas 


\section{Comportamento mecânico do concreto projetado com fibras no revestimento de túneis}

\section{1.}

\section{Introdução}

O concreto projetado reforçado com fibras é aplicado em obras de mineração visando a estabilização do maciço rochoso após a escavação. Dessa maneira, o estudo do comportamento mecânico do material desempenha um papel fundamental no dimensionamento do concreto projetado com fibras com o objetivo de garantir a segurança da área de trabalho dentro dos túneis subterrâneos. Na mina Cuiabá, em especial, as escavações vêm atingindo grandes profundidades em busca de novos depósitos de ouro acarretando em grandes e rápidas deformações após a escavação do maciço rochoso. O principal desafio, portanto, de uma das principais minas de ouro brasileiras é o ajuste do sistema de suporte em escavações de grandes profundidades.

Com o objetivo de estudar o comportamento mecânico do concreto projetado reforçado com fibras de aço e dois tipos de fibra poliméricas utilizado na mina Cuiabá, foi realizado um programa experimental que se inicia com o estudo do compósito na escala material e se encerra com a análise do comportamento mecânico através de ensaios de painel. Como a interface possui um efeito significativo na resposta mecânica do concreto com fibras [114], foram realizados ensaios de arrancamento das fibras estudadas, além de ensaios de flexão em prismas de acordo com a norma europeia EN 14651 [54] para caracterização do material. Em seguida, ensaios de flexão em painéis circulares e quadrados foram executados visando o dimensionamento do concreto projetado reforçado com fibras em obras de escavação. Por fim, um ensaio de flexão em painel de larga escala foi conduzido com a finalidade de estudar o comportamento mecânico do sistema de suporte na escala mais próxima da observada nas obras de mineração. 


\section{2.}

\section{Programa experimental}

A nomenclatura dos compósitos segue o seguinte padrão: PPF1 referente à fibra sintética da TamFib SP54, PPF2 referente à fibra sintética da BarChip54; SF referente à fibra de aço Dramix 3D 65/35. Foram adicionadas à mistura 4,2 kg/m³, $6 \mathrm{~kg} / \mathrm{m}^{3}$ e $8 \mathrm{~kg} / \mathrm{m}^{3}$ de fibras sintéticas PPF1 e PPF2 nesse trabalho. No caso das fibras de aço: $25 \mathrm{~kg} / \mathrm{m}^{3}, 40 \mathrm{~kg} / \mathrm{m}^{3}$ e $60 \mathrm{~kg} / \mathrm{m}^{3}$. O concreto projetado na mina Cuiabá foi reforçado com $4,2 \mathrm{~kg} / \mathrm{m}^{3}, 6 \mathrm{~kg} / \mathrm{m}^{3}$ e $8 \mathrm{~kg} / \mathrm{m}^{3}$ de PPF1 e $25 \mathrm{~kg} / \mathrm{m}^{3}$ de SF. A Tabela 12 apresenta um resumo do programa experimental. $\mathrm{O}$ índice $-P$ indica as amostras de concreto projetado com fibras que foram fabricadas na mina e enviadas para o laboratório da PUC-Rio. Como os engenheiros da mina Cuiabá não usam mais a fibra BarChip54, PPF2 foi estudada somente na escala material.

Tabela 12 - Programa experimental para a análise do comportamento mecânico do concreto com

fibras para revestimento de túneis

\begin{tabular}{|c|c|c|c|}
\hline \multirow{3}{*}{ Ensaios de Arrancamento } & TamFib SP54 & $20 \mathrm{~mm}$ & PPF1 $20 \mathrm{~mm}$ \\
\hline & BarChip54 & $20 \mathrm{~mm}$ & PPF2 $20 \mathrm{~mm}$ \\
\hline & Dramix 3D 65/35 & $20 \mathrm{~mm}$ & SF $20 \mathrm{~mm}$ \\
\hline \multirow{9}{*}{ Ensaios de flexão em prismas } & \multirow{3}{*}{ TamFib SP54 } & $4,2 \mathrm{~kg} / \mathrm{m}^{3}$ & C4.2PPF1 \\
\hline & & $6 \mathrm{~kg} / \mathrm{m}^{3}$ & C6.0PPF1 \\
\hline & & $8 \mathrm{~kg} / \mathrm{m}^{3}$ & C8.0PPF1 \\
\hline & \multirow{3}{*}{ BarChip54 } & $4,2 \mathrm{~kg} / \mathrm{m}^{3}$ & C4.2PPF2 \\
\hline & & $6 \mathrm{~kg} / \mathrm{m}^{3}$ & C6.0PPF2 \\
\hline & & $8 \mathrm{~kg} / \mathrm{m}^{3}$ & C8.0PPF2 \\
\hline & \multirow{3}{*}{ Dramix 3D $65 / 35$} & $25 \mathrm{~kg} / \mathrm{m}^{3}$ & $\mathrm{C} 25 \mathrm{SF}$ \\
\hline & & $40 \mathrm{~kg} / \mathrm{m}^{3}$ & C40SF \\
\hline & & $60 \mathrm{~kg} / \mathrm{m}^{3}$ & C60SF \\
\hline \multirow{4}{*}{$\begin{array}{c}\text { Ensaios de flexão em painéis } \\
\text { circulares }\end{array}$} & \multirow{3}{*}{ TamFib SP54 } & $4,2 \mathrm{~kg} / \mathrm{m}^{3}$ & C4.2PPF1-P \\
\hline & & $6 \mathrm{~kg} / \mathrm{m}^{3}$ & C6.0PPF1-P \\
\hline & & $8 \mathrm{~kg} / \mathrm{m}^{3}$ & C8.0PPF1-P \\
\hline & Dramix 3D 65/35 & $25 \mathrm{~kg} / \mathrm{m}^{3}$ & C25SF-P \\
\hline $\begin{array}{c}\text { Ensaios de flexão em painéis } \\
\text { quadrados } \\
\end{array}$ & TamFib SP54 & $4,2 \mathrm{~kg} / \mathrm{m}^{3}$ & C4.2PPF1-P \\
\hline Ensaios de larga escala & TamFib SP54 & $4,2 \mathrm{~kg} / \mathrm{m}^{3}$ & C4.2PPF1 \\
\hline
\end{tabular}




\section{3.}

\section{Fabricação das amostras}

No caso da moldagem dos corpos de prova prismáticos produzidos para a realização dos ensaios de flexão em prismas, a mistura foi realizada na betoneira com capacidade de $400 \mathrm{~L}$. As dimensões dos corpos de prova foram de 550 x 150 x $150 \mathrm{~mm}$, como especificado na norma EN 14651 [54].

Os moldes metálicos foram preparados com óleo desmoldante antes da moldagem. $\mathrm{O}$ adensamento foi realizado com golpes externos e com a utilização do martelo de borracha durante o lançamento do concreto. A desforma foi realizada 24 horas após a moldagem. A cura foi realizada em ambiente de temperatura e umidade controladas por 28 dias. Entalhes de $25 \mathrm{~mm}$ de altura foram realizados na metade da face inferior dos prismas, conforme especificado na norma EN 14651 [54].

Para moldagem dos corpos de prova do ensaio de arrancamento, foi usado um misturador planetário com capacidade $5 \mathrm{~L}$. Os moldes consistem em tubos de PVC de $25 \mathrm{~mm}$ de diâmetro e $20 \mathrm{~mm}$ de comprimento fixados em placas de acrílico (Figura 42). As fibras foram adicionadas à amostra após a moldagem dos tubos. Os ensaios foram realizados após 28 dias de cura em ambiente com temperatura e umidade controladas.

Os painéis circulares e quadrados enviados da mina Cuiabá foram fabricados com a projeção de concreto do robô de projeção. No caso dos painéis circulares, utilizou-se formas com base de compensado e anel metálico com diâmetro de 800 $\mathrm{mm}$ e espessura de $80 \mathrm{~mm}$ (Figura 43). Os painéis quadrados foram moldados em formas de madeira quadradas de $600 \mathrm{~mm}$ de lado e $100 \mathrm{~mm}$ de espessura.

Para a fabricação da amostra de painel de larga escala, foi elaborada em uma forma de $1300 \mathrm{~mm}$ x $1300 \mathrm{~mm}$ com espessura de $80 \mathrm{~mm}$ (Figura 44), que é a maior espessura de concreto projetado utilizada na mina Cuiabá. Procedimento semelhante ao realizado na moldagem dos prismas foi aplicado ao painel com o uso da betoneira de 400 L. A cura foi realizada através de uma manta de cura saturada sobre a superfície do painel. 


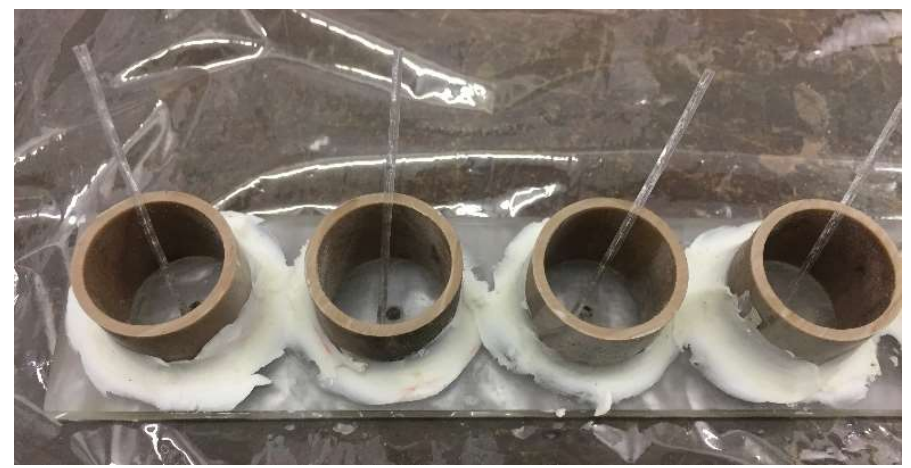

Figura 42 - Moldes de PVC em base de acrílico usados para a moldagem das amostras para o ensaio de arrancamento

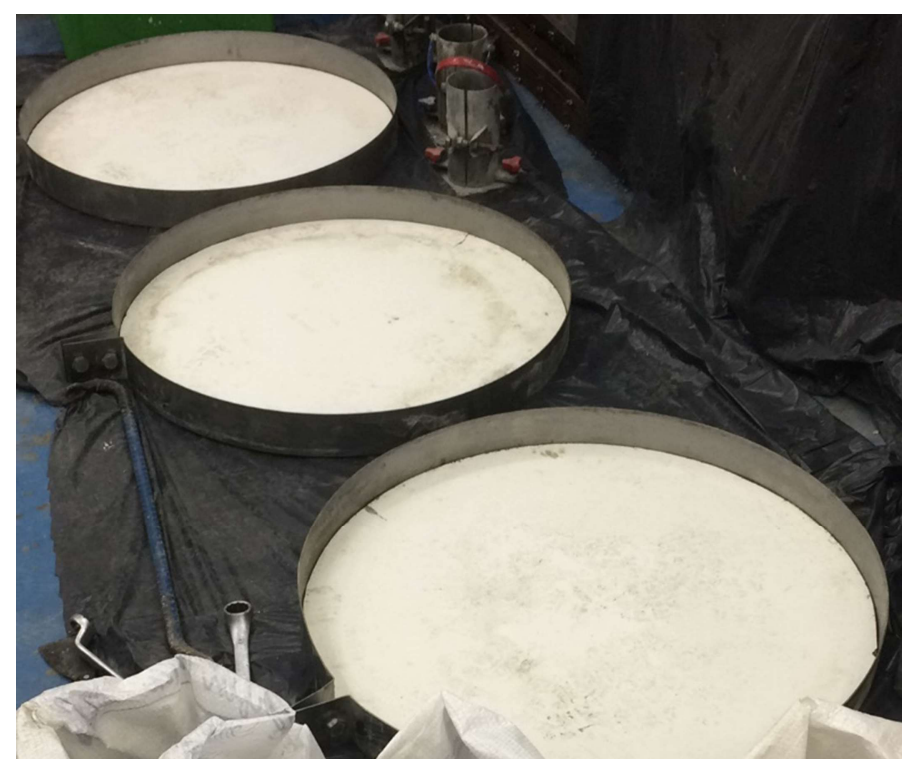

Figura 43 - Formas usadas para moldagem dos painéis circulares

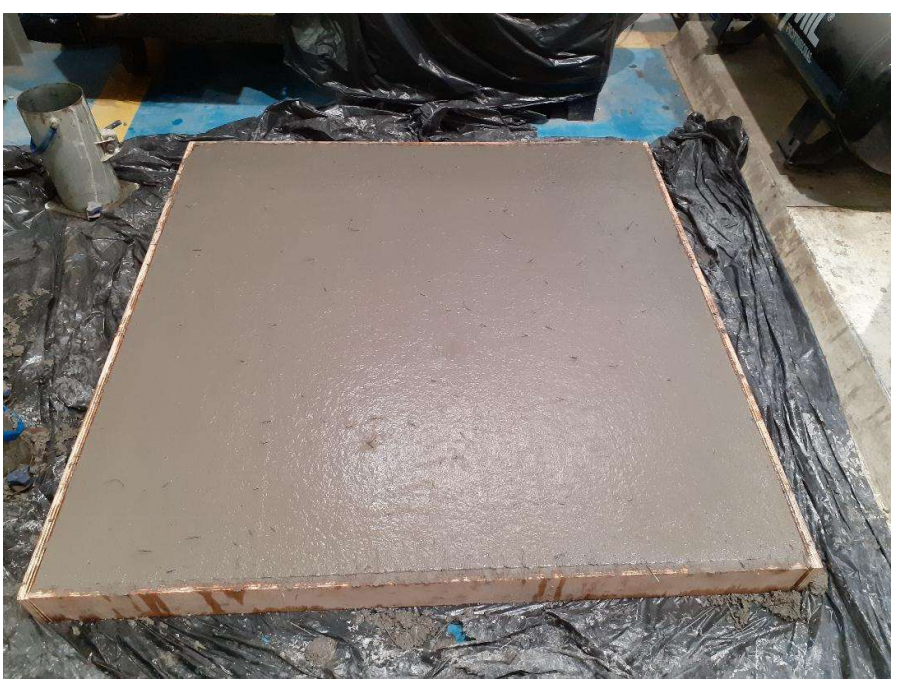

Figura 44 - Forma de madeira usada para a moldagem do painel de larga escala 


\section{4 .}

\section{Ensaios mecânicos}

\subsection{1.}

\section{Ensaios de arrancamento}

A fim de avaliar a transferência de força por cisalhamento entre as fibras e a matriz, foram realizados ensaios de arrancamento. Como as fibras de polipropileno analisadas apresentam um comprimento de $54 \mathrm{~mm}$, todos os ensaios foram realizados com o mesmo comprimento de embebimento $\left(\mathrm{L}_{\mathrm{c}}\right)$ de $20 \mathrm{~mm}$.

A escolha desse comprimento de embebimento teve como objetivo simular o que ocorre no concreto reforçado com fibras. Caso a fibra apresente um comprimento de embebimento maior de um lado em relação ao outro na região da fissura, o menor comprimento será aquele que define o comportamento da interface, devido a uma menor área de cisalhamento $[32,34]$. Dessa maneira, o comprimento de embebimento deve apresentar um valor igual ou menor que metade da fibra analisada. Como a fibra de aço usada apresenta apenas $35 \mathrm{~mm}$ de comprimento, foi utilizada a fibra de aço Dramix 3D 65/60, que apresenta as mesmas propriedades materiais que a Dramix 3D 65/35, só que com 60 mm de comprimento.

Para as três fibras analisadas, 6 corpos de prova foram fabricados. Os ensaios de arrancamento foram realizados através de um atuador servo hidráulico MTS com capacidade de $250 \mathrm{kN}$. Uma célula de carga de $2,5 \mathrm{kN}$ foi acoplada ao arranjo experimental. O controle do ensaio foi feito através do deslocamento do LVDT interno do atuador a uma taxa de $1,5 \mathrm{~mm} / \mathrm{min}$. As amostras foram fixadas em garras, caracterizando uma condição de contorno fixa. A base da amostra tinha seu deslocamento impedido devido à presença de um anel metálico fixado com três parafusos. O sistema completo do ensaio pode ser visualizado na Figura 45 e o desenho esquemático está na Figura 46. Mais detalhes sobre o mesmo ensaio de arrancamento podem ser encontrados nos trabalhos de Castoldi [51] e Nogueira [115]. 


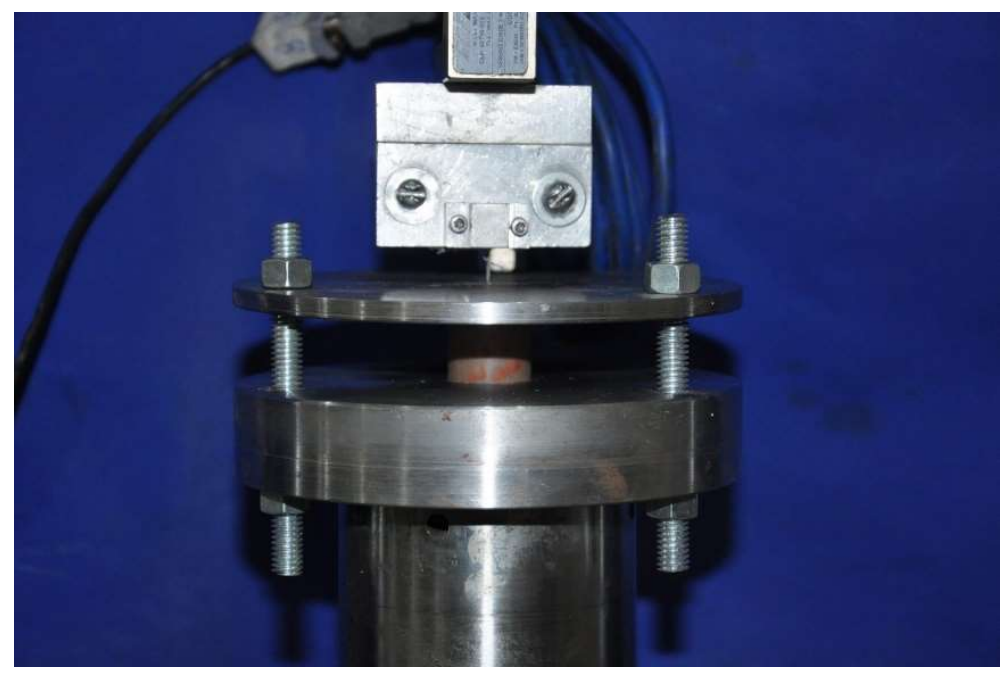

Figura 45 - Configuração do ensaio de arrancamento
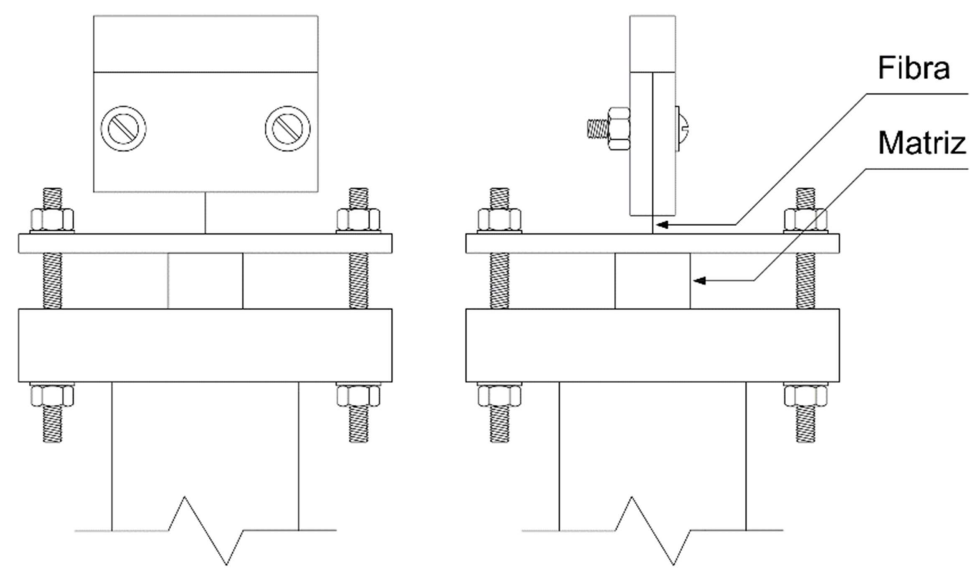

Figura 46 - Desenho esquemático do ensaio de arrancamento

A tensão de cisalhamento máxima ( $\left.\tau_{\text {máx }}\right)$ foi calculada a partir da força medida pela célula de carga divido pela área superficial lateral, como indicado na Equação 5.

$$
\tau_{\text {máx }}=\frac{P_{\max }}{2 \pi r L_{c}}
$$

onde $\mathrm{P}_{\text {máx }}$ é a carga máxima, $\mathrm{r}$ o raio equivalente (em caso de fibras não circulares) obtido a partir da seção transversal da fibra e $\mathrm{L}_{c} \mathrm{o}$ comprimento de embebimento (20 mm). 


\subsection{2.}

\section{Ensaios de flexão em prismas}

Ensaios de flexão em três pontos foram realizados em corpos de prova prismáticos de seção retangular, de acordo com a norma europeia EN 14651 [54]. As dimensões dos prismas foram $550 \mathrm{~mm}$ x $150 \mathrm{~mm}$ x $150 \mathrm{~mm}$, com entalhe de 25 $\mathrm{mm}$ de altura na altura da região central da face inferior dos prismas. A moldagem dos corpos de prova seguiu o procedimento indicado na seção 3.3. A Figura 47 apresenta as dimensões dos prismas e o setup utilizado para a realização do ensaio.

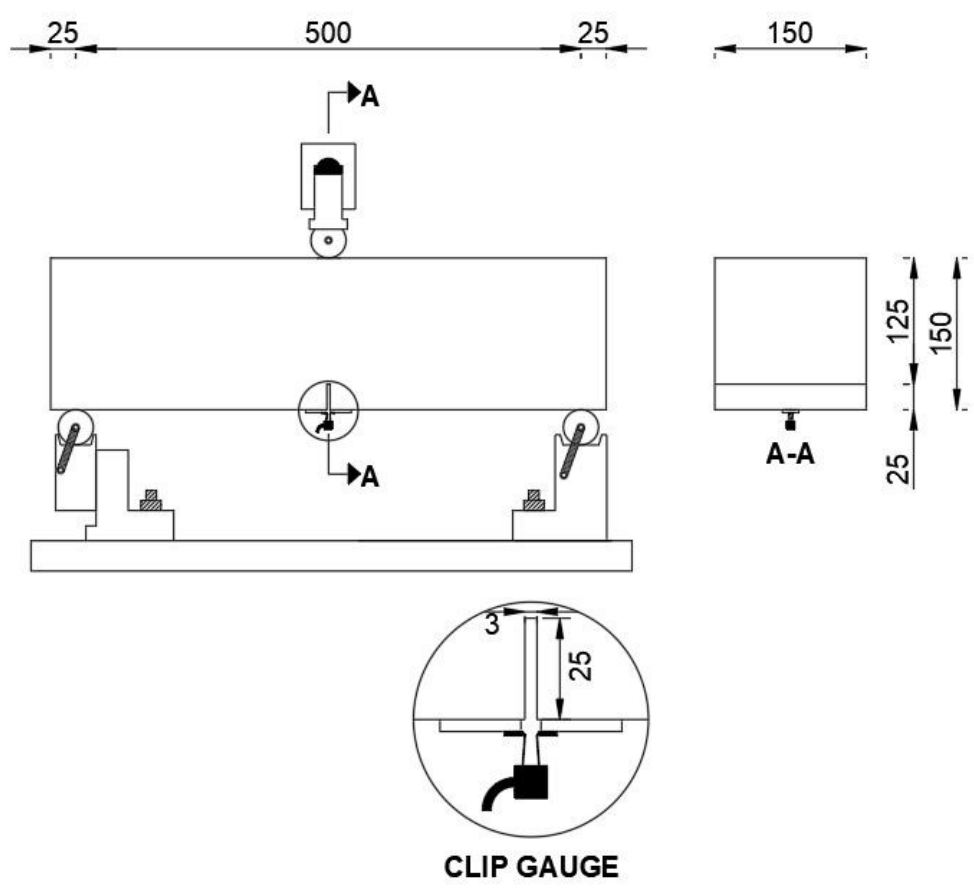

Figura 47 - Desenho esquemático do ensaio de flexão baseado na norma EN 14651 [54].

Dimensões em mm.

Tanto os roletes de apoio quanto os roletes de aplicação de carga apresentavam $37 \mathrm{~mm}$ de diâmetro. O vão entre apoios foi de $500 \mathrm{~mm}$. A aplicação de carga foi centralizada em relação à face superior do prisma. Para cada condição analisada, 3 corpos de prova foram fabricados. Os ensaios de flexão foram realizados através de um atuador servo hidráulico MTS com capacidade de $100 \mathrm{kN}$.

A abertura de fissura (Crack Mouth Opening Displacement, CMOD) foi medida a partir do entalhe, que induzia o posicionamento da fissura naquela seção. A Figura 48 mostra o ensaio de flexão em três pontos antes da aplicação do carregamento. Os valores de CMOD foram obtidos com a utilização de um clip gauge, fixado em peças metálicas na região do entalhe. Os ensaios foram 
controlados externamente pelo clip gange a uma taxa de $0,1 \mathrm{~mm} / \mathrm{min}$ até atingir uma abertura de fissura de $4 \mathrm{~mm}$. A aquisição de dados foi realizada com frequência de $5 \mathrm{~Hz}$. A Figura 49 mostra o detalhe do posicionamento do clip gauge na face inferior do prisma.

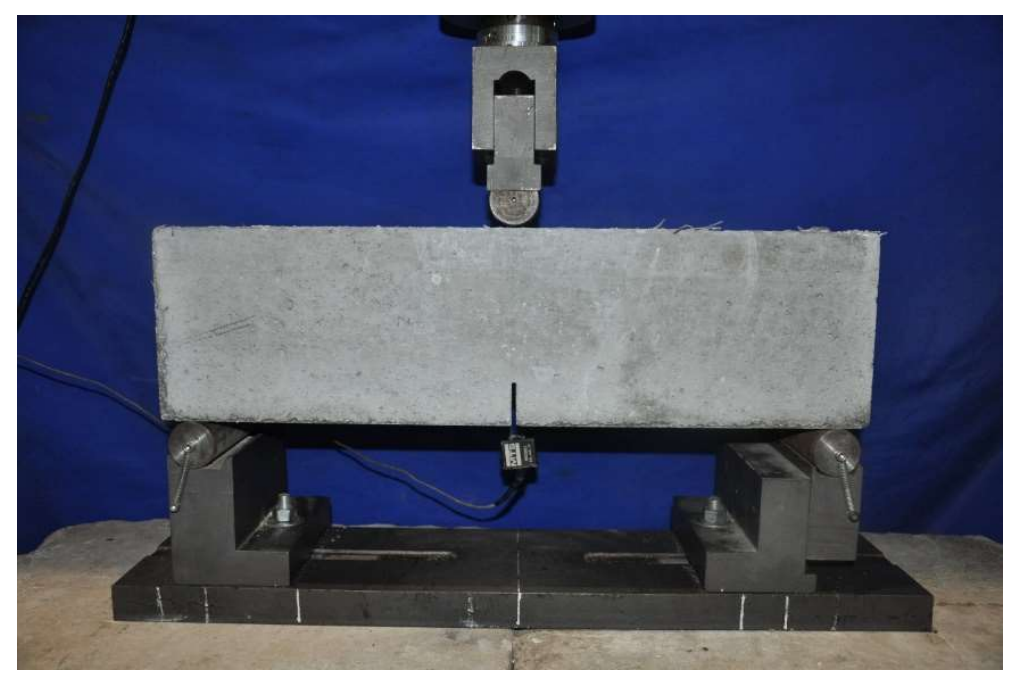

Figura 48 - Ensaio de flexão em três pontos (EN 14651)

A partir dos ensaios, é possível plotar as curvas de tensão por CMOD, sendo os valores de tensão obtidos a partir da Equação 6 .

$$
\sigma=\frac{3 P S}{2 b h_{s p}^{2}}
$$

$\mathrm{O}$ termo $\mathrm{P}$ refere-se à carga aplicada, $\mathrm{S}$ ao vão de ensaio, $\mathrm{b}$ a largura do corpo de prova e $h_{\mathrm{sp}}$ a distância entre o topo do entalhe e a face inferior do prisma.

A partir da execução do ensaio de flexão de acordo com a norma EN 14651 [54], o CEB-FIB [55] recomenda a determinação das tensões residuais $f_{L}, f_{R, 1}$ e $f_{R, 3}$. A tensão $f_{R, 1}$ é correspondente à abertura de fissura de $0,5 \mathrm{~mm}$, enquanto a tensão $f_{R, 3}$ é correspondente à abertura de fissura de $2,5 \mathrm{~mm}$. A tensão $f_{L}$ está associada a à máxima tensão compreendida entre 0 e $0,05 \mathrm{~mm}$ de abertura de fissura (CMOD). As diretrizes do CEB-FIB [55] recomendam os seguinte limites para o uso do concreto reforçado com fibras: $f_{R, 3} / f_{R, 1}>0,5$ para o estado limite último e $f_{R, 1} / f_{L}>$ 0,4 para o estado limite de serviço. 


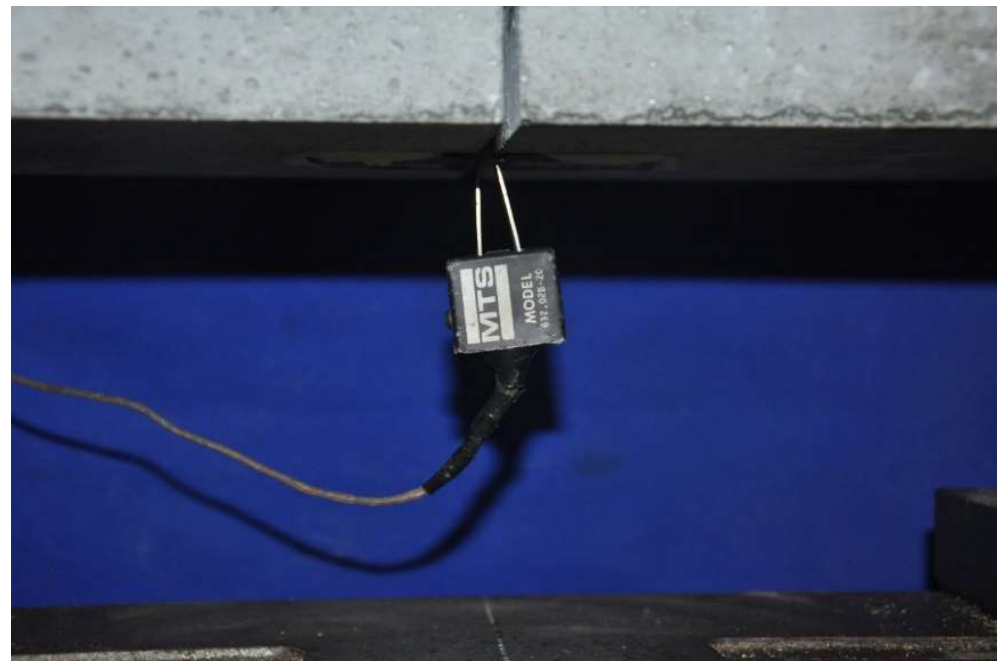

Figura 49 - Detalhe do clip gauge na face inferior do prisma

\subsection{3.}

\section{Ensaios de flexão em painéis circulares}

Antes da execução do ensaio, foram realizadas marcações auxiliares, em ambas as faces do painel. Na face superior, marcava-se o centro para orientar o ponto de atuação da carga. Já na face inferior, marcava-se o centro para orientar a instrumentação. Os centros eram marcados com o auxílio de esquadro de centro, lápis e régua.

Depois da realização das marcações dos pontos de interesse, seguia-se com a fixação dos apoios no próprio disco utilizando a fita adesiva dupla face $3 \mathrm{M}^{\circledR}$. A montagem dos suportes se inicia com o posicionamento dos suportes de apoio que consistiam em três apoios de alumínio de $50 \mathrm{~mm}$ de diâmetro, unidos por barras rosqueadas e providos de esferas rotuladas. A configuração do sistema de ensaio formava um arranjo triangular equilátero com arestas de $65 \mathrm{~cm}$. Por fim, posicionava-se o painel circular com o auxílio da empilhadeira mecânica até a máquina de ensaios mecânicos. A Figura 50 mostra um desenho esquemático do ensaio de flexão em painel circular de acordo com a ASTM C1550 [49]. 


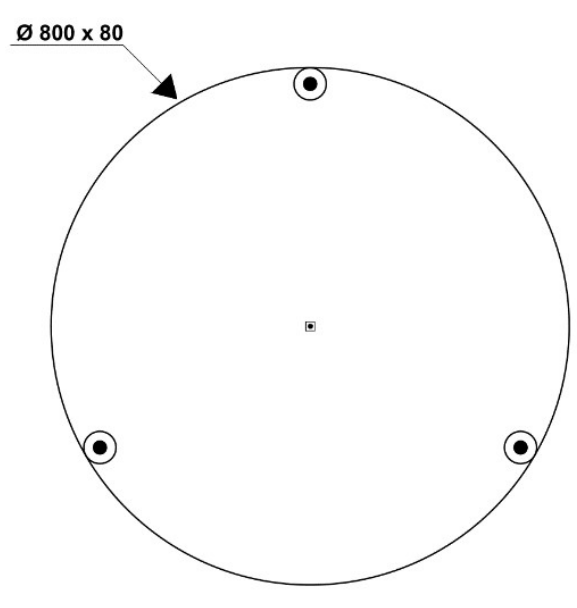

(a)

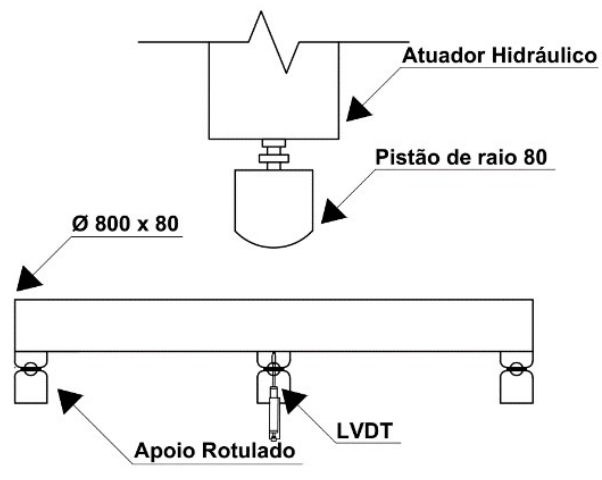

(b)

Figura 50 - Desenho esquemático do ensaio de flexão em painel circular: (a) disposição dos apoios no painel e (b) ilustração do ensaio e posicionamento do LVDT. Dimensões em mm.

Todos os testes foram executados em sistema de ensaios mecânicos com atuador servo hidráulico MTS com capacidade de carga de $500 \mathrm{kN}$. O ensaio foi realizado por controle de deslocamento a uma taxa de $2 \mathrm{~mm} / \mathrm{min}$ até o deslocamento final de $40 \mathrm{~mm}$. Para melhor precisão em relação ao deslocamento central utilizouse um transdutor de deslocamento Gefram de $100 \mathrm{~mm}$. A Figura 51 mostra o ensaio de flexão em painel circular antes da aplicação do carregamento.

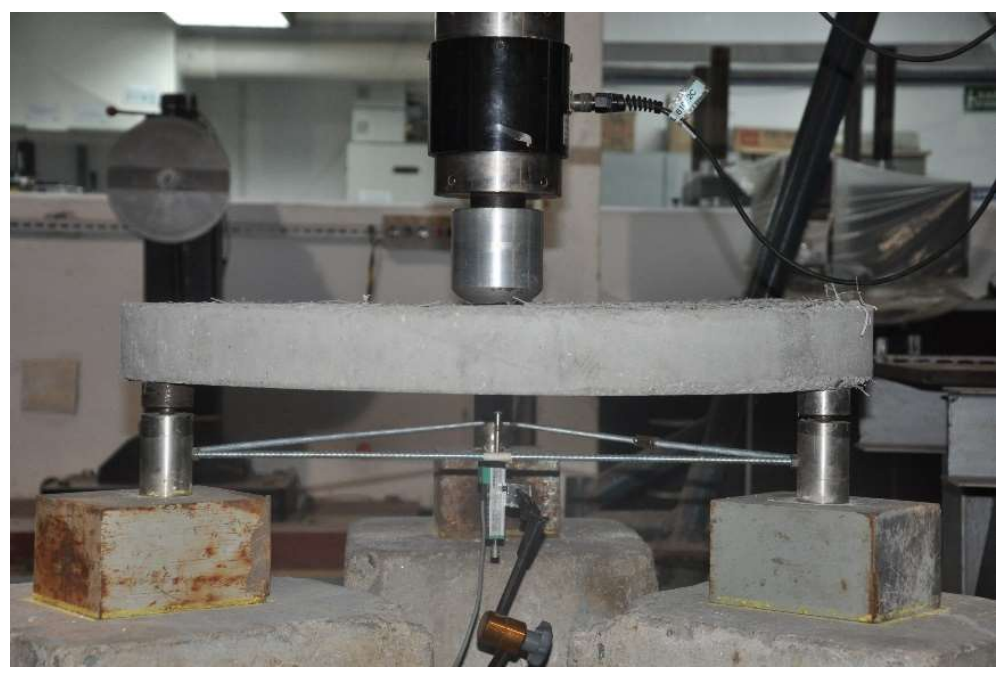

Figura 51 - Detalhe do painel circular na máquina de ensaios 


\subsection{4.}

\section{Ensaios de flexão em painéis quadrados}

Para a realização dos ensaios de flexão em painéis quadrados, foram moldados painéis com $600 \mathrm{~mm}$ de lado e $100 \mathrm{~mm}$ de espessura, como estabelecido pela norma europeia EN 14488-5 [50]. Todas as amostras foram confeccionadas in loco na obra da mina Cuiabá, como descrito na seção 4.3.2, e enviadas para o Laboratório de Estruturas e Materiais da PUC-Rio.

Antes da realização do ensaio mecânico, posicionou-se o apoio quadrado de $500 \mathrm{~mm}$ de lado sobre quatro blocos de mesmas dimensões formando um apoio contínuo. A fim de garantir que o apoio não se movimentaria, aplicou-se a cola epóxi Sikadur ${ }^{\circledR}$ sobre os blocos e situou-se o suporte quadrado contínuo de forma centralizada em relação ao eixo do atuador mecânico com a ajuda do laser.

Em seguida, marcou-se o centro das faces superior e inferior dos painéis com o auxílio de lápis e régua. Os painéis foram, então, levados para a máquina de ensaios com a da empilhadeira mecânica. Uma chapa metálica de $26 \mathrm{~mm}$ de espessura e $100 \mathrm{~mm}$ de lado foi posicionada sobre o centro do painel. Por fim, adicionou-se uma rótula e mais um suporte metálico sobre a chapa. As Figuras 52 e 53 mostram um desenho esquemático e uma ilustração do ensaio realizado, respectivamente.

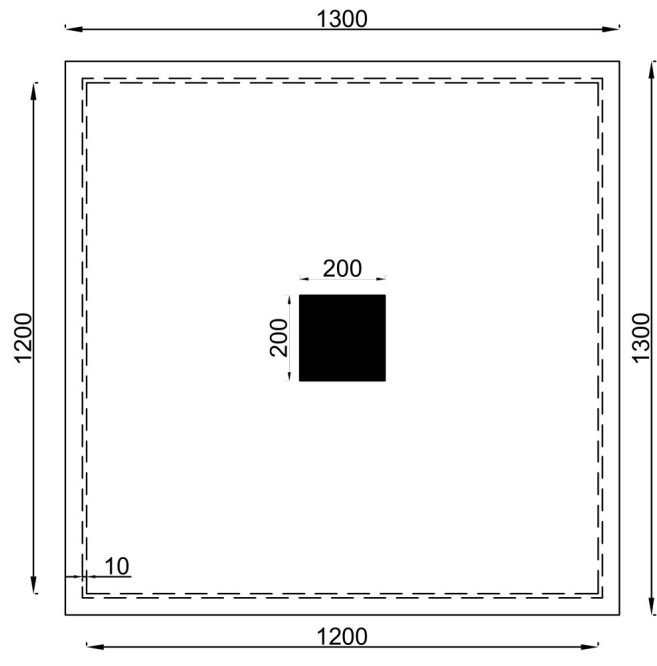

(a)

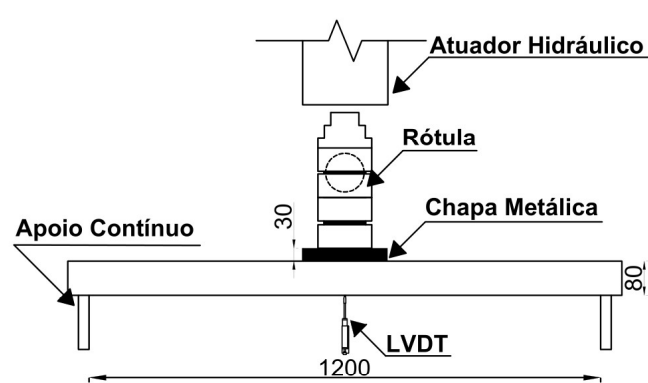

(b)

Figura 52 - Desenho esquemático do ensaio de flexão em painel quadrado: (a) disposição do arranjo experimental do painel e (b) ilustração do ensaio e posicionamento do LVDT. Dimensões em mm. 
Todos os testes foram executados em sistema de ensaios mecânicos com atuador servo hidráulico MTS com capacidade de carga de $500 \mathrm{kN}$. O ensaio foi realizado por controle de deslocamento a uma taxa de $1 \mathrm{~mm} / \mathrm{min}$ até o deslocamento final de $30 \mathrm{~mm}$. Para melhor precisão em relação ao deslocamento central utilizouse um transdutor de deslocamento Gefram de $100 \mathrm{~mm}$ de curso.

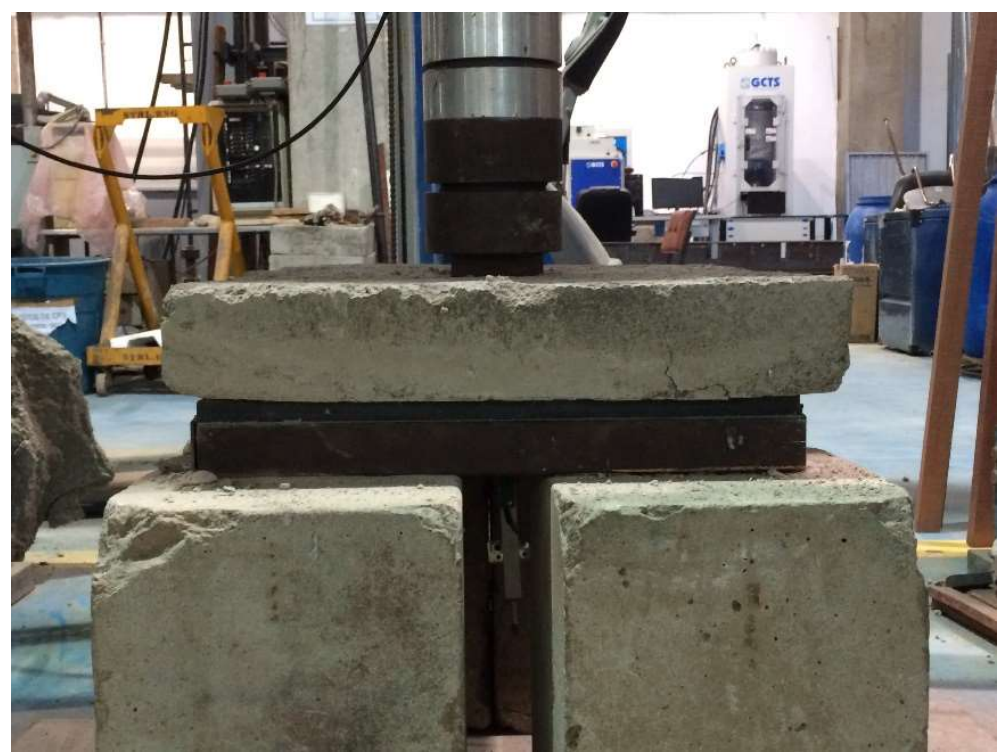

Figura 53 - Detalhe do painel quadrado na máquina de ensaios

\subsection{5. \\ Ensaios de flexão em painéis de larga escala}

Para a realização do ensaio de flexão de larga escala, foi moldado um painel com $1300 \mathrm{~mm}$ de lado e $80 \mathrm{~mm}$ de espessura. A amostra foi confeccionada no Laboratório de Estruturas e Materiais da PUC-Rio.

Antes da realização do ensaio mecânico, posicionou-se o apoio quadrado de $1200 \mathrm{~mm}$ de lado sobre quatro blocos de mesmas dimensões formando um apoio contínuo. A fim de garantir que o apoio não se movimentaria, aplicou-se a cola epóxi Sikadur ${ }^{\circledR}$ sobre os blocos e situou-se o suporte quadrado de forma centralizada em relação ao eixo do atuador mecânico com a ajuda do laser. O arranjo experimental adotado e as dimensões da amostra tiveram como base o trabalho de Morton [13]. Uma chapa metálica de $30 \mathrm{~mm}$ de espessura e $200 \mathrm{~mm}$ de lado foi posicionada sobre o centro do painel. A Figura 54 traz uma imagem de ilustração do ensaio de larga escala antes do início do carregamento e a Figura 55 mostra um desenho esquemático do ensaio realizado. 


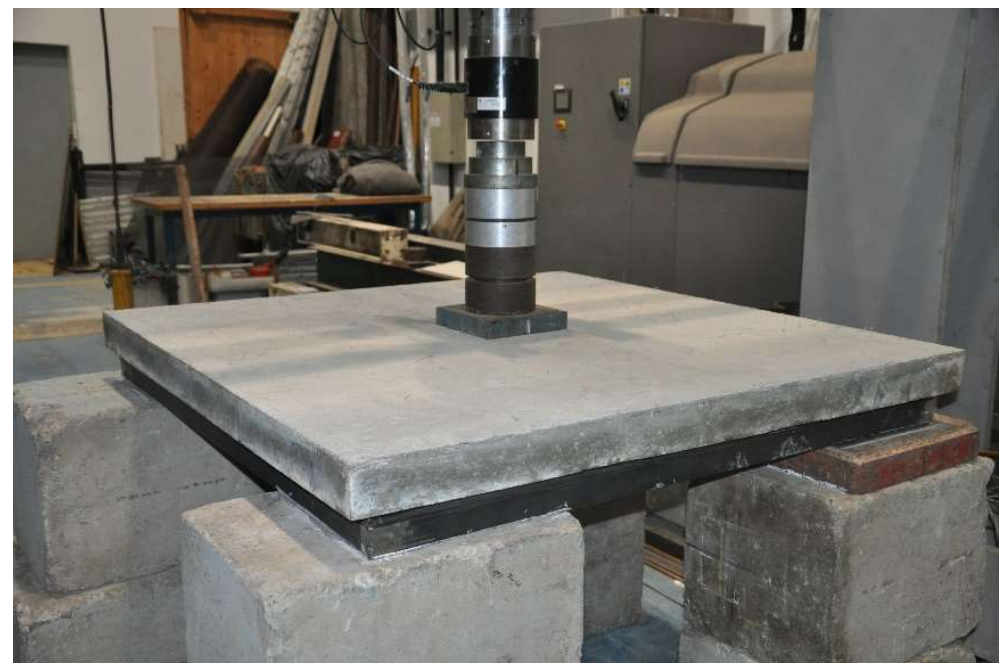

Figura 54 - Ensaio de painel de larga escala

Todos os testes foram executados em sistema de ensaios mecânicos com atuador servo hidráulico MTS com capacidade de carga de $500 \mathrm{kN}$. O ensaio foi realizado por controle de deslocamento a uma taxa de $1 \mathrm{~mm} / \mathrm{min}$ até a ruptura. Para melhor precisão em relação ao deslocamento central utilizou-se um transdutor de deslocamento Gefram de $100 \mathrm{~mm}$.

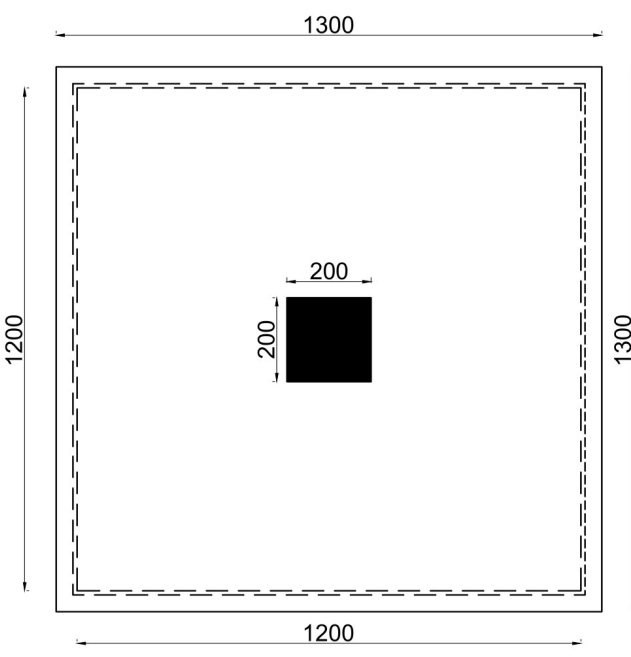

(a)

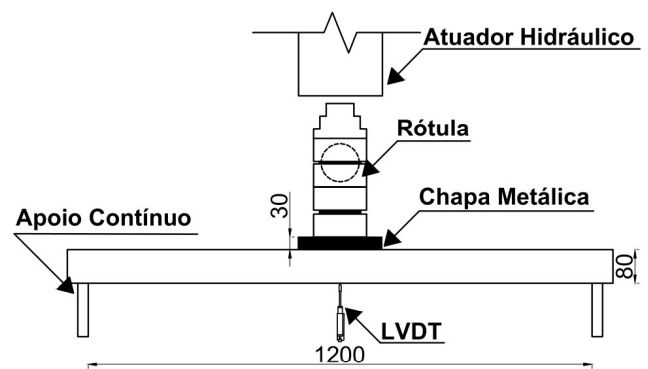

(b)

Figura 55 - Desenho esquemático do ensaio de flexão em painel de larga escala: (a) disposição do setup do painel e (b) ilustração do ensaio e posicionamento do LVDT. Dimensões em mm. 


\section{5 .}

\section{Resultados e discussões}

\subsection{1.}

\section{Caracterização do concreto reforçado com fibras}

A Figura 56 apresenta as curvas de tensão por CMOD obtidos dos ensaios de flexão em três pontos de acordo com a norma EN 14651 [54]. Os resultados mostram o comportamento pós-fissuração do concreto reforçado com dois tipos diferentes de fibras sintéticas (PPF1 e PPF2) em três frações volumétricas (4.2, 6 e $\left.8 \mathrm{~kg} / \mathrm{m}^{3}\right)$.

De acordo com a norma EN 14651 [54], a tensão de primeira fissura (limite de proporcionalidade) é calculada a partir do maior valor do início do ensaio até $0,05 \mathrm{~mm}$ de abertura de fissura $\left(\mathrm{f}_{\mathrm{L}}\right)$. Como definido no CEB-FIB [55], $\mathrm{f}_{\mathrm{R}, \mathrm{i}}$ é a tensão residual obtida do ensaio de flexão em prismas com $\mathrm{i}=1,2,3$ e 4, respectivamente, de acordo com os valores de CMOD iguais a 0,5, 1,5, 2,5, 3,5 mm. A tenacidade $\left(\mathrm{T}_{4,0}\right)$ foi calculada a partir da área sob as curvas de força por CMOD. As diretrizes do CEB-FIB [55] recomendam o cálculo de $f_{R, 3} / f_{R, 1}$ e $f_{R, 1} / f_{L}$ para a análise do concreto reforçado com fibras nos estados limites último e de serviço, respectivamente. Os parâmetros estudados estão na Tabela 13.

É possível observar um comportamento linear até o aparecimento da primeira fissura do material, seguido por uma diminuição da tensão com o aumento do CMOD. Esse comportamento é denominado de deflection softening, definido como a deterioração da resistência do material com o aumento de suas deformações [34] e muito comum em concreto reforçado com fibras poliméricas [115-117]. É possível perceber que a resistência de primeira fissura $\left(\mathrm{f}_{\mathrm{L}}\right)$ praticamente não varia com o tipo de fibra usada ou a fração volumétrica, já que esse valor está associado com a resistência à tração da matriz cimentícia. 


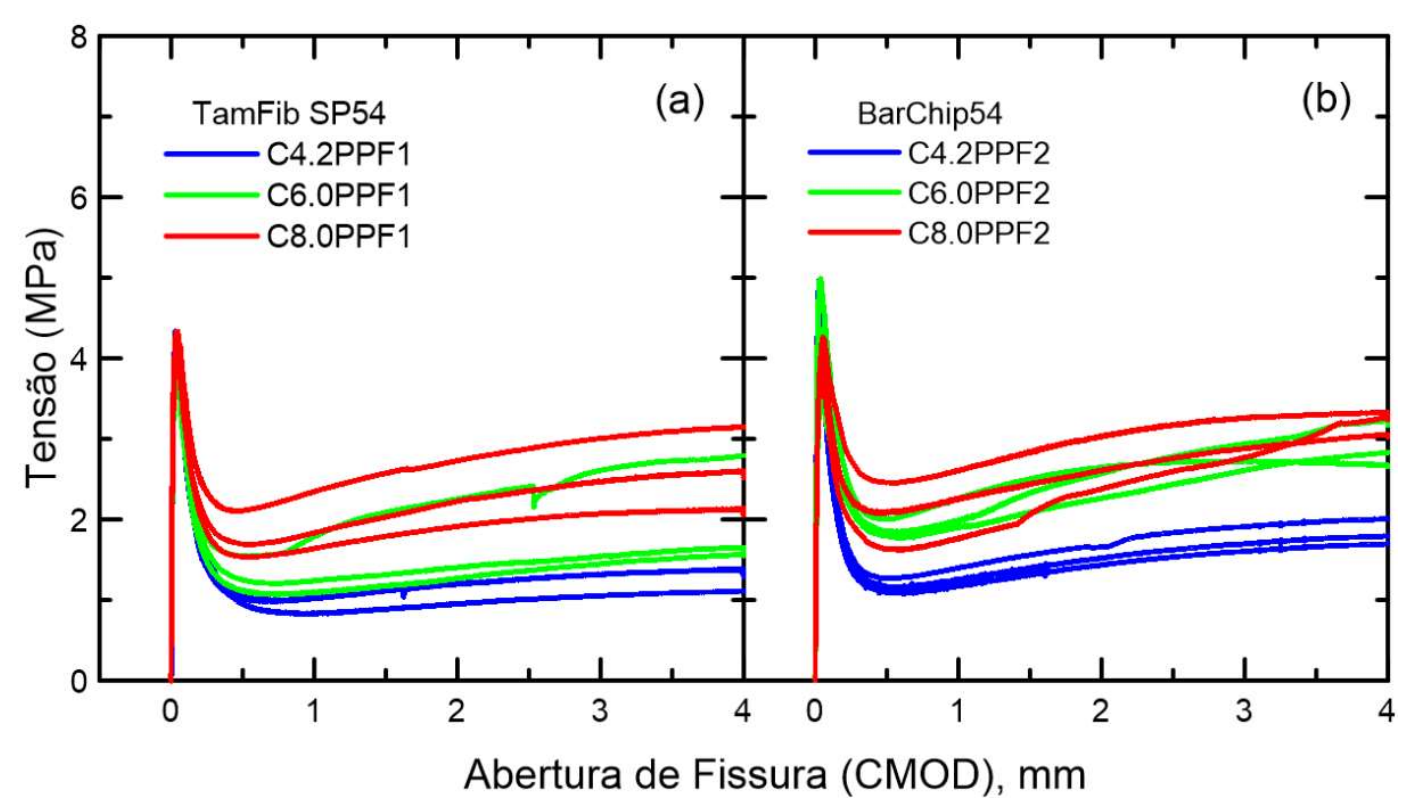

Figura 56 - Resultados dos ensaios de flexão em três pontos de acordo com a norma EN 14651

[54] para o concreto reforçado com dois tipos de fibra polimérica em diferentes frações volumétricas: (a) TamFib SP54 (PPF1) e (b) BarChip54 (PPF2)

A Figura 57 mostra os resultados do concreto reforçado com as duas fibras poliméricas (PPF1 e PPF2) divididos pelas frações volumétricas analisadas. É possível perceber que o concreto reforçado com PPF2 apresenta tanto uma resistência pós-físsuração quanto tenacidade ligeiramente maiores quanto comparado ao material com adição de PPF1 para todas as frações estudadas. Como elas possuem praticamente o mesmo comprimento e o mesmo fator de forma, essa diferença deve estar associada às propriedades materiais da fibra e, principalmente, devido sua aderência na matriz cimentícia. Essa diferença fica mais clara ao comparar os valores de tensão $\mathrm{f}_{\mathrm{R}, 4}$ nas composições com $6 \mathrm{~kg} / \mathrm{m}^{3}$ de fibras: C6.0PPF1 e C6.0PPF2 apresentam 1,88 MPa e 3,10 MPa, respectivamente.

Em termos mecânicos, portanto, a fibra PPF2 apresenta maiores valores em quase todos os parâmetros mecânicos analisados. Por outro lado, o concreto projetado com da mina Cuiabá utiliza atualmente a fibra PPF1 para a contenção das deformações do maciço rochoso. Essa escolha foi realizada por motivos econômicos pela empresa.

A Figura 58(a) apresenta o comportamento mecânico dos prismas reforçados com $25 \mathrm{~kg} / \mathrm{m}^{3}, 40 \mathrm{~kg} / \mathrm{m}^{3}$ e $60 \mathrm{~kg} / \mathrm{m}^{3}$ de fibra de aço e as Figuras 58(b) e 58(c) compara os resultados obtidos das fibras de polipropileno com C25SF. Como 
esperado, o comportamento pós-pico das curvas de tensão por CMOD diferem consideravelmente ao comparar as fibras de aço e polipropileno, devido à grande diferença entre os módulos de elasticidade e, principalmente, à maior aderência da fibra da aço na matriz cimentícia, que será analisada através dos ensaios de arrancamento.

Tabela 13 - Resumo dos parâmetros obtidos dos ensaios de flexão em três pontos de acordo com a norma EN 14651 [54]. Desvio padrão indicado entre parênteses

\begin{tabular}{|c|c|c|c|c|c|c|c|c|}
\hline Composição & $\begin{array}{c}\mathrm{f}_{\mathrm{L}} \\
(\mathrm{MPa})\end{array}$ & $\begin{array}{c}\mathrm{f}_{\mathrm{R}, 1} \\
(\mathrm{MPa})\end{array}$ & $\begin{array}{c}\mathrm{f}_{\mathrm{R}, 2} \\
(\mathrm{MPa})\end{array}$ & $\begin{array}{c}\mathrm{f}_{\mathrm{R}, 3} \\
(\mathrm{MPa})\end{array}$ & $\begin{array}{c}\mathrm{f}_{\mathrm{R}, 4} \\
(\mathrm{MPa})\end{array}$ & $\begin{array}{c}\mathrm{T}_{4,0} \\
(\mathrm{~J})\end{array}$ & $\begin{array}{c}\mathrm{f}_{\mathrm{R}, 3} / \mathrm{f}_{\mathrm{R}, 1} \\
-\end{array}$ & $\begin{array}{c}\mathrm{f}_{\mathrm{R}, 1} / \mathrm{f}_{\mathrm{L}} \\
-\end{array}$ \\
\hline C4.2PPF1 & $\begin{array}{c}4,29 \\
(0,23)\end{array}$ & $\begin{array}{c}1,01 \\
(0,04)\end{array}$ & $\begin{array}{c}1,04 \\
(0,13)\end{array}$ & $\begin{array}{c}1,18 \\
(0,14)\end{array}$ & $\begin{array}{c}1,26 \\
(0,16)\end{array}$ & $\begin{array}{l}15,48 \\
(1,78)\end{array}$ & 1,169 & 0,235 \\
\hline C6.0PPF1 & $\begin{array}{c}4,03 \\
(0,04)\end{array}$ & $\begin{array}{c}1,30 \\
(0,22)\end{array}$ & $\begin{array}{c}1,52 \\
(0,49)\end{array}$ & $\begin{array}{c}1,74 \\
(0,57)\end{array}$ & $\begin{array}{c}1,88 \\
(0,56)\end{array}$ & $\begin{array}{l}21,38 \\
(5,29)\end{array}$ & 1,342 & 0,323 \\
\hline C8.0PPF1 & $\begin{array}{c}4,24 \\
(0,16)\end{array}$ & $\begin{array}{c}1,78 \\
(0,30)\end{array}$ & $\begin{array}{c}2,13 \\
(0,44)\end{array}$ & $\begin{array}{c}2,41 \\
(0,44)\end{array}$ & $\begin{array}{c}2,58 \\
(0,49)\end{array}$ & $\begin{array}{l}28,81 \\
(5,01)\end{array}$ & 1,355 & 0,420 \\
\hline C4.2PPF2 & $\begin{array}{c}4,59 \\
(0,36)\end{array}$ & $\begin{array}{c}1,18 \\
0,09)\end{array}$ & $\begin{array}{c}1,42 \\
(0,13)\end{array}$ & $\begin{array}{c}1,66 \\
(0,15)\end{array}$ & $\begin{array}{c}1,80 \\
(0,16)\end{array}$ & $\begin{array}{l}20,41 \\
(1,34)\end{array}$ & 1,411 & 0,256 \\
\hline C6.0PPF2 & $\begin{array}{c}4,34 \\
(0,65)\end{array}$ & $\begin{array}{c}1,88 \\
(0,11)\end{array}$ & $\begin{array}{c}2,30 \\
(0,21)\end{array}$ & $\begin{array}{c}2,64 \\
(0,19)\end{array}$ & $\begin{array}{c}3,10 \\
(0,40)\end{array}$ & $\begin{array}{l}31,24 \\
(1,85)\end{array}$ & 1,404 & 0,433 \\
\hline C8.0PPF2 & $\begin{array}{c}4,03 \\
(0,22)\end{array}$ & $\begin{array}{c}2,06 \\
(0,41)\end{array}$ & $\begin{array}{c}2,44 \\
(0,39)\end{array}$ & $\begin{array}{c}2,84 \\
(0,30)\end{array}$ & $\begin{array}{c}3,11 \\
(0,17)\end{array}$ & $\begin{array}{l}33,48 \\
(3,75)\end{array}$ & 1,378 & 0,511 \\
\hline $\mathrm{C} 25 \mathrm{SF}$ & $\begin{array}{c}5,08 \\
(0,13)\end{array}$ & $\begin{array}{c}2,70 \\
(0,24)\end{array}$ & $\begin{array}{c}2,96 \\
(0,18)\end{array}$ & $\begin{array}{c}2,95 \\
(0,14)\end{array}$ & $\begin{array}{c}2,78 \\
(0,26)\end{array}$ & $\begin{array}{l}36,31 \\
(2,01)\end{array}$ & 1,094 & 0,531 \\
\hline C40SF & $\begin{array}{c}4,47 \\
(0,41)\end{array}$ & $\begin{array}{c}2,95 \\
(0,63)\end{array}$ & $\begin{array}{c}3,16 \\
(0,53)\end{array}$ & $\begin{array}{c}3,07 \\
(0,45)\end{array}$ & $\begin{array}{c}2,80 \\
(0,33)\end{array}$ & $\begin{array}{l}37,71 \\
(5,82)\end{array}$ & 1,038 & 0,661 \\
\hline C60SF & $\begin{array}{c}4,43 \\
(0,16)\end{array}$ & $\begin{array}{c}3,62 \\
(0,37)\end{array}$ & $\begin{array}{c}4,28 \\
(0,31)\end{array}$ & $\begin{array}{c}4,15 \\
(0,36)\end{array}$ & $\begin{array}{c}3,83 \\
(0,29)\end{array}$ & $\begin{array}{l}49,65 \\
(3,10)\end{array}$ & 1,146 & 0,817 \\
\hline
\end{tabular}

$\mathrm{f}_{\mathrm{L}}=$ tensão correspondente ao limite de proporcionalidade

$\mathrm{f}_{\mathrm{R}, 1}=$ resistência residual à flexão correspondente a CMOD de $0,5 \mathrm{~mm}$

$\mathrm{f}_{\mathrm{R}, 2}=$ resistência residual à flexão correspondente a CMOD de $1,5 \mathrm{~mm}$

$\mathrm{f}_{\mathrm{R}, 3}=$ resistência residual à flexão correspondente a CMOD de $2,5 \mathrm{~mm}$

$\mathrm{f}_{\mathrm{R}, 4}=$ resistência residual à flexão correspondente a CMOD de $3,5 \mathrm{~mm}$

$\mathrm{T}_{4,0}=$ tenacidade até $\mathrm{CMOD}$ de $4,0 \mathrm{~mm}$

Apesar da adição das fibras de aço nas frações volumétricas analisadas também apresentarem o comportamento de deflection softening, o concreto reforçado $25 \mathrm{~kg} / \mathrm{m}^{3}$ de fibra de aço resultou em um maior valor de resistências residuais e tenacidade em relação a todas as outras composições analisadas com 
fibra de PP. Em média, nenhum dos compósitos com fibras PP atingiu $36 \mathrm{~J}$ de tenacidade, valor obtido com $25 \mathrm{~kg} / \mathrm{m}^{3}$ de fibra de aço.

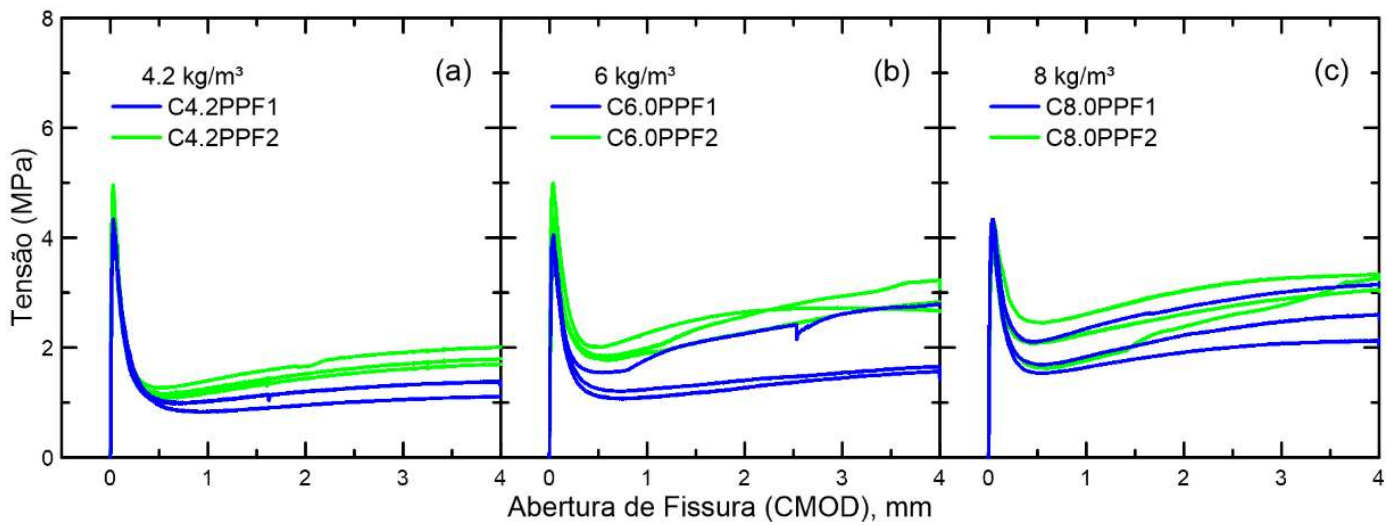

Figura 57 - Resultados dos ensaios de flexão em três pontos de acordo com a norma EN 14651

[54] para o concreto reforçado com as fibras poliméricas TamFib SP54 (PPF1) e BarChip54

(PPF2) divididos nas frações volumétricas analisadas: (a) $4.2 \mathrm{~kg} / \mathrm{m}^{3}$, (b) $6 \mathrm{~kg} / \mathrm{m}^{3} \mathrm{e}$ (c) $8 \mathrm{~kg} / \mathrm{m}^{3}$

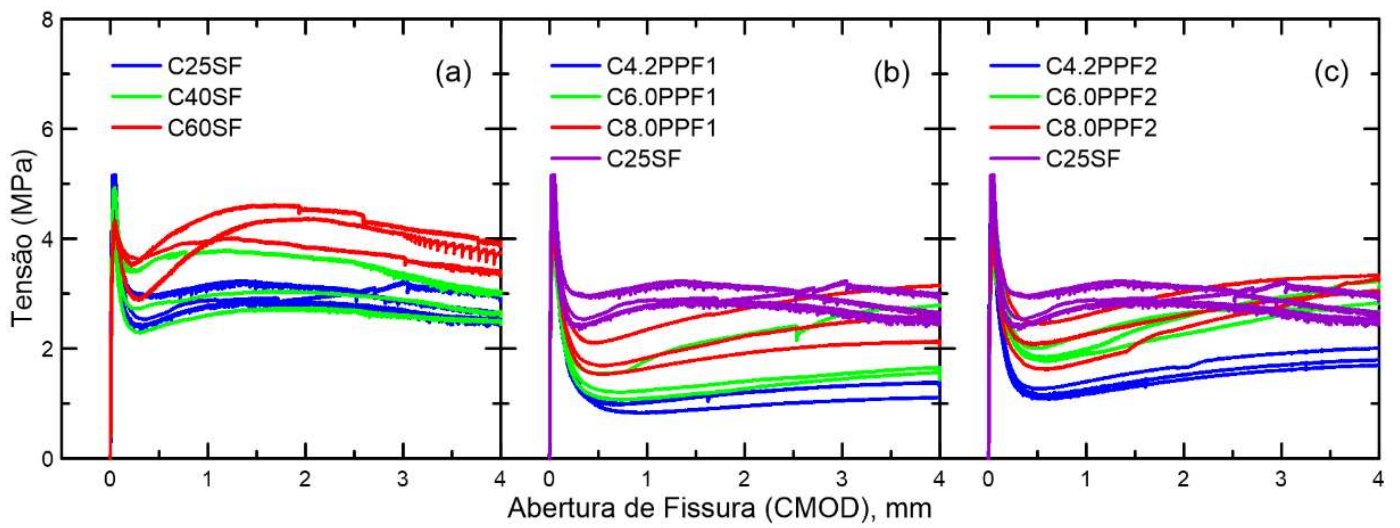

Figura 58 - Resultados dos ensaios de flexão em três pontos de acordo com a norma EN 14651:

(a) concreto reforçado com diferentes frações volumétricas de fibra de aço, (b) comparação entre a adição de $25 \mathrm{~kg} / \mathrm{m}^{3}$ de fibra de aço e adição da fibra de PPF1 e (c) comparação entre a adição de $25 \mathrm{~kg} / \mathrm{m}^{3}$ de fibra de aço e adição da fibra de PPF2

Por outro lado, a adição das fibras sintéticas consegue promover uma resistência pós-fissuração praticamente constante para as frações estudadas após atingir valores de abertura de fissura por volta de $3 \mathrm{~mm}$. Esse fator pode ser analisado através da classificação indicada na Tabela 13 na razão $f_{R, 3} / f_{R, 1}$. $O$ concreto reforçado com PP conseguiu atingir em quase todas as frações valores acima de 1,30. Já o material reforçado com as fibras de aço mostrou, em geral, resultados menores que 1,20 de manutenção da resistência pós-fissuração. Dessa 
maneira, o uso de altos teores de fibras sintéticas, acima de $6 \mathrm{~kg} / \mathrm{m}^{3}$, pode ser mais eficiente em manter a resistência pós-pico para grandes aberturas de fissuras.

Ao analisar os resultados nos primeiros níveis de abertura de fissura através de $f_{R, 1} / f_{L}$, a adição de fibras de aço é mais efetiva em melhorar o desempenho mecânico do concreto. Para todas as frações volumétricas estudadas, a fibra de aço apresenta maiores valores de $f_{R, 1} / f_{L}$ que 0,40 , atendendo os limites estabelecidos pelo CEB-FIB [55].

Papworth [48] explica, em suas orientações para o dimensionamento do sistema de suporte, que a seleção do tipo de fibras também deve levar em conta a magnitude de deformações observadas após a escavação. Em casos onde médias ou pequenas deformações são observadas, as fibras de aço podem ser a melhor opção com uma maior capacidade de resistir aos esforços externos. Em casos de grandes deformações, o uso de altos teores de fibras sintéticas pode ser a melhor opção por atingirem maiores tensões residuais em maiores aberturas de fissuras.

Além das propriedades materiais das fibras, sua eficiência como reforço está diretamente relacionada às interações na interface com a matriz. Essas interações na interface incluem sua adesão química, por atrito e ancoragem mecânica [32] e podem ser avaliadas de forma geral a partir do ensaio de arrancamento. A Figura 59 apresenta as curvas dos ensaios de arrancamento realizadas nas fibras de aço (SF) e nas duas fibras de polipropileno estudadas (PPF1 e PPF2). Os valores de carga máxima $\left(\mathrm{P}_{\text {máx }}\right)$ e tensão máxima de aderência $\left(\tau_{\text {máx }}\right)$ estão apresentados na Tabela 14. É possível observar um completo arrancamento das fibras avaliadas, já que não há ruptura da fibra durante os ensaios de arrancamento. O processo de descolamento se inicia após atingir a carga máxima de arrancamento $\mathrm{P}_{\text {máx}}$. 


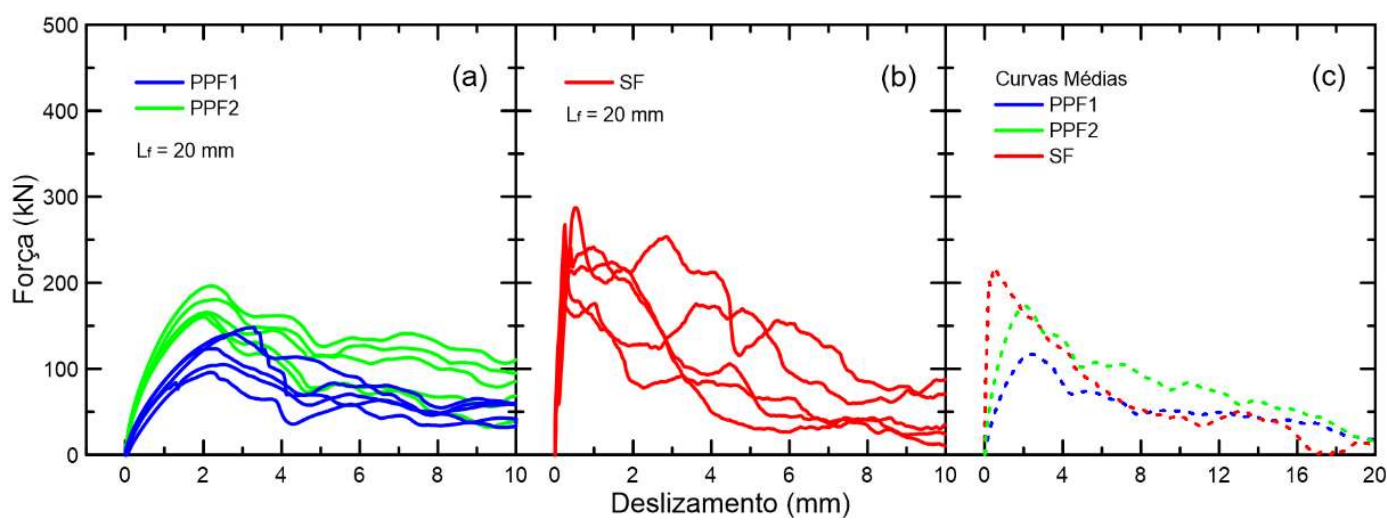

Figura 59 - Resultados dos ensaios de arrancamento: (a) comparação entre as fibras PPF1 e PPF2,

(b) arrancamento das fibras SF e (c) curvas médias para as três fibras analisadas

Tabela 14 - Resultados de carga e tensão de aderência máximas do ensaio de arrancamento.

Desvio padrão indicado entre parênteses

\begin{tabular}{cccc}
\hline Fibra & $\begin{array}{c}\text { Comprimento de embebimento } \\
(\mathrm{mm})\end{array}$ & $\begin{array}{c}\mathrm{P}_{\text {máx }} \\
(\mathrm{N})\end{array}$ & $\begin{array}{c}\tau_{\text {máx }} \\
(\mathrm{MPa})\end{array}$ \\
\hline \multirow{2}{*}{ PPF1 } & 20 & 122,46 & 2,24 \\
& & $(22,30)$ & $(0,40)$ \\
PPF2 & 20 & 173,18 & 3,00 \\
& & $(15,08)$ & $(0,26)$ \\
SF & 20 & 246,88 & 4,37 \\
& & $(30,34)$ & $(0,54)$ \\
\hline
\end{tabular}

Baseado nos resultados obtidos nos ensaios de arrancamento, é possível perceber altos valores de aderência das fibras PPF1 e PPF2 com 2,24 e 3,00 MPa, respectivamente. Nogueira [115], Castoldi [116] e Di Maida et al. [118] reportaram tensões máxima menores que $1 \mathrm{MPa}$ em ensaios de arrancamento das fibras de polipropileno em diferentes embebimentos. Babafemi et al. [119] explicam que a maior aderência dessas fibras está associada com o relevo presente na superfície das fibras sintéticas analisadas. A influência desse relevo pode ser observada pela curva em formato de onda na região pós-pico. Dessa maneira, as deformações superficiais ajudam a melhorar a aderência das fibras na matriz cimentícia, acarretando em uma maior tensão de aderência.

As Figura 59(b) mostra os resultados do arrancamento das fibras de aço. A fibra SF atingiu 4,37 MPa de tensão máxima de aderência, que é consideravelmente maior que as fibras sintéticas. A diferença significativa entre os dois tipos de fibra 
está associada principalmente a ancoragem da fibra de aço [120, 121]. Enquanto a fibra de polipropileno possui somente a tensão de cisalhamento interfacial quando é arrancada da matriz cimentícia, a fibra de aço apresenta uma componente a mais devido a ancoragem do gancho.

Por fim, a Figura 59(c) traz as curvas médias obtidas a partir dos resultados dos ensaios de arrancamento conduzidos para as três fibras analisadas. Apesar da fibra de aço apresentar uma maior tensão de pico, há uma rápida queda na força de arrancamento após a deformação do gancho na extremidade da fibra [122]. É possível perceber que, após atingir $8 \mathrm{~mm}$ de deslizamento, a força de arrancamento já apresenta resultados próximos ao da fibra PPF1 e menores que PPF2.

Os resultados apresentados na Figura 59 corroboram com a resposta mecânica obtida nos ensaios de flexão. As maiores tensões de tração na flexão estão associadas com a maior aderência das fibras de aço com a presença do gancho, além de suas propriedades materiais. Já a maior eficiência das fibras sintéticas na manutenção das tensões pós-pico do concreto com fibras pode ser explicada através da maior força de arrancamento após o início de seu deslizamento.

\subsection{2.}

\section{Classificação do concreto com fibras a partir de ensaios de flexão em painéis}

A Figura 60 mostra os resultados dos ensaios de flexão em painéis circulares de concreto projetado com fibras de aço e PPF1. Todos os resultados da Figura 60 foram provenientes de amostras fabricadas na mina Cuiabá e enviadas para a realização dos testes mecânicos na PUC-Rio. A Tabela 16 apresenta os resultados de tenacidade em diferentes níveis de deflexão da amostra (10, 20, 30 e $40 \mathrm{~mm})$, além da carga de pico média. $\mathrm{O}$ índice de performance de tenacidade e classe de rocha foi aplicado de acordo com a Tabela 5. Os resultados indicados com $-P$ estão associados às amostras que foram fabricadas com o robô de projeção e enviadas para o laboratório. Devido a motivos econômicos, a fibra BarChip54 (PPF2) não é mais usada pela equipe que trabalha na mina Cuiabá e, portanto, ela só foi analisada na escala material na seção 5.5.1. 

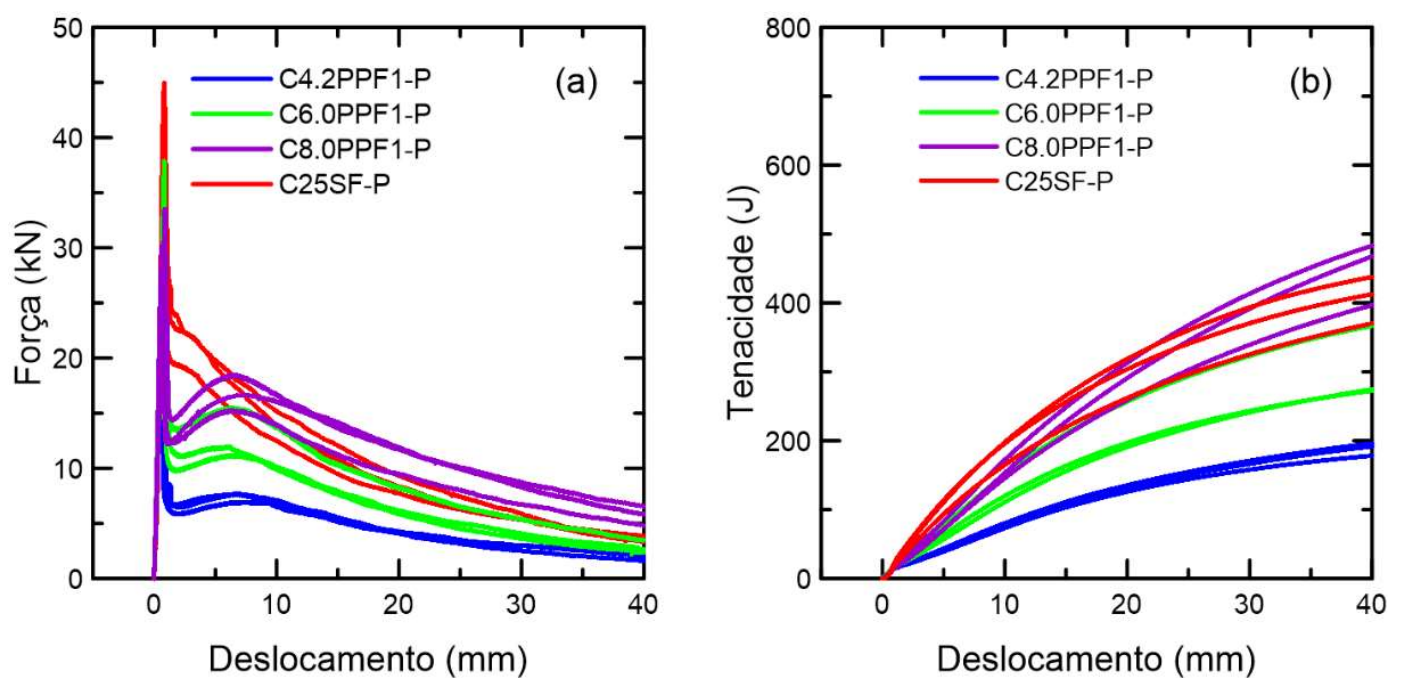

Figura 60 - Resultados dos ensaios de flexão em painéis circulares (ASTM C1550 [49]) do concreto projetado com fibras. Amostras fabricadas na mina Cuiabá: (a) curvas de força por deslocamento e (b) tenacidade por deslocamento

Tabela 15 - Resultados de tenacidade, carga última e classificação de índice de tenacidade para o concreto reforçado com as diferentes frações de fibra de aço e sintética analisadas após o ensaios de flexão em painel circular (ASTM C1550 [49]). O índice $-P$ indica as amostras de concreto projetado com fibras que foram fabricadas na mina Cuiabá. Desvio padrão indicado entre parênteses

\begin{tabular}{|c|c|c|c|c|c|c|}
\hline Composição & $\begin{array}{c}\mathrm{P}_{\mathrm{u}} \\
(\mathrm{kN})\end{array}$ & $\begin{array}{l}\mathrm{T}_{10} \\
(\mathrm{~J})\end{array}$ & $\begin{array}{l}\mathrm{T}_{20} \\
(\mathrm{~J})\end{array}$ & $\begin{array}{l}\mathrm{T}_{30} \\
(\mathrm{~J})\end{array}$ & $\begin{array}{l}\mathrm{T}_{40} \\
(\mathrm{~J})\end{array}$ & $\begin{array}{c}\text { TPL* } \\
\text { Classe de Rocha }\end{array}$ \\
\hline \multirow{2}{*}{ C4.2PPF1-P } & 31,48 & 77,70 & 131,24 & 164,94 & 188,51 & 0 \\
\hline & $(0,69)$ & $(3,94)$ & $(4,77)$ & $(6,47)$ & $(9,22)$ & $\mathrm{A}$ \\
\hline \multirow{2}{*}{ C6.0PPF1-P } & 32,78 & 127,14 & 214,72 & 269,00 & 304,46 & III \\
\hline & $(4,63)$ & $(20,96)$ & $(36,36)$ & $(46,72)$ & $(53,85)$ & $\mathrm{D}$ \\
\hline \multirow{2}{*}{ C8.0PPF1-P } & 30,51 & 156,92 & 287,64 & 381,29 & 448,91 & IV \\
\hline & $(2,84)$ & $(13,77)$ & $(27,24)$ & $(38,14)$ & $(46,06)$ & $\mathrm{E}$ \\
\hline \multirow{2}{*}{ C25SF-P } & 41,216 & 186,092 & 294,651 & 362,918 & 406,746 & IV \\
\hline & $(4,84)$ & $(18,43)$ & $(29,40)$ & $(34,03)$ & $(34,03)$ & $\mathrm{E}$ \\
\hline
\end{tabular}

*Índice de Performance de Tenacidade

Assim como observado nos ensaios de flexão, o aumento das frações volumétricas de fibras de sintéticas acarretaram em um aumento da resistência pósfissuração e da tenacidade. A adição de $8 \mathrm{~kg} / \mathrm{m}^{3}$ da fibra PPF1, por exemplo, 
apresentou mais que o dobro da tenacidade em $40 \mathrm{~mm}$ de deslocamento da amostra $\left(\mathrm{T}_{40}\right)$ quando comparada com C4.2PPF1-P.

A classificação da tenacidade de acordo com o nível de degradação da rocha, indicada por Papworth [48], também varia de acordo com fração de fibra. É possível perceber pela Tabela 15 que a escolha da fração volumétrica e do tipo de fibra depende diretamente das condições do maciço rochoso a qual o concreto será projetado. Enquanto o uso de $4,2 \mathrm{~kg} / \mathrm{m}^{3}$ da fibra PPF1 está indicada apenas em casos em que a rocha apresenta condições muito boas (classe de rocha $\mathrm{A}$ ), o concreto projetado com $8 \mathrm{~kg} / \mathrm{m}^{3}$ da mesma fibra já está indicado para situação de rocha com condições muito fracas (classe de rocha $\mathrm{E}$ ).

Em relação ao tipo de fibra aplicado, a adição de $25 \mathrm{~kg} / \mathrm{m}^{3}$ de SF apresentou resultados de tenacidade e TPL equivalentes ao uso de $8 \mathrm{~kg} / \mathrm{m}^{3}$ de PPF1. Dessa maneira, uma quantidade maior em volume de fibras sintéticas é necessária para atingir resultados próximos do uso de fibras de aço. Essa diferença está associada principalmente ao maior módulo da fibra de aço e sua maior tensão de aderência máxima, como abordado na seção 5.5.1. Além disso, vale ressaltar o pequeno desvio padrão obtido nos resultados dos ensaios de flexão em painéis, mostrando que três amostras apresentam um resultado confiável para a análise dos parâmetros mecânicos.

Baseado no trabalho de Barbosa [97], que classificou diversos corpos do maciço rochoso (sistema Q, RMR) da Fonte Grande Sul e Serrotinho, o local compreende rochas de qualidade fraca até boa com uma variação do valor de Q entre aproximadamente 1 e 22 no domínio da Capa do Minério. Na mina Cuiabá, aplica-se um espaçamento entre tirantes de 1,5 m. A Tabela 7 mostra a classificação da rocha na mina Cuiabá. A Figura 61 apresenta o ábaco de Grimstad \& Barton [38] modificado por Papworth [48] com a indicação da região do dimensionamento para a Mina Cuiabá. A Tabela 16 mostra a classificação do sistema de suporte de acordo com a variação da qualidade do maciço rochoso mostrada na Figura 61. Vale ressaltar que diferentes autores podem recomendar diferentes sistemas de suporte. Raffaldi et al. [36], por exemplo, recomendam o uso de telas metálicas junto com concreto projetado no dimensionamento.

Dessa maneira, baseado nos resultados obtidos através dos ensaios de painel circular na Tabela 15, recomenda-se a aplicação de uma fração mais alta de fibra sintética PPF1 com $6 \mathrm{~kg} / \mathrm{m}^{3}$ nas regiões com qualidade da rocha fraca (Q entre 1 e 
4) e espessura de 5-9 cm, como indicado pela Região 5 da Tabela 16. Nas regiões com qualidade boa e razoável ( $\mathrm{Q}$ acima de 4) e espaçamento entre tirantes menor que $2 \mathrm{~m}$, não é recomendando o uso de concreto projetado no sistema de suporte. Dessa maneira, pode-se adicionar uma fração mínima 4,2 kg/m³ de PPF1 com uma espessura de $5 \mathrm{~cm}$ para controle da degradação da rocha, como explicado na Região 1 da Figura 61. O uso de maiores frações de PPF1 ou da fibra de aço somente se torna necessário em casos com qualidade da rocha muito fraca, que não foi apresentado nos resultados indicados por Barbosa [97].

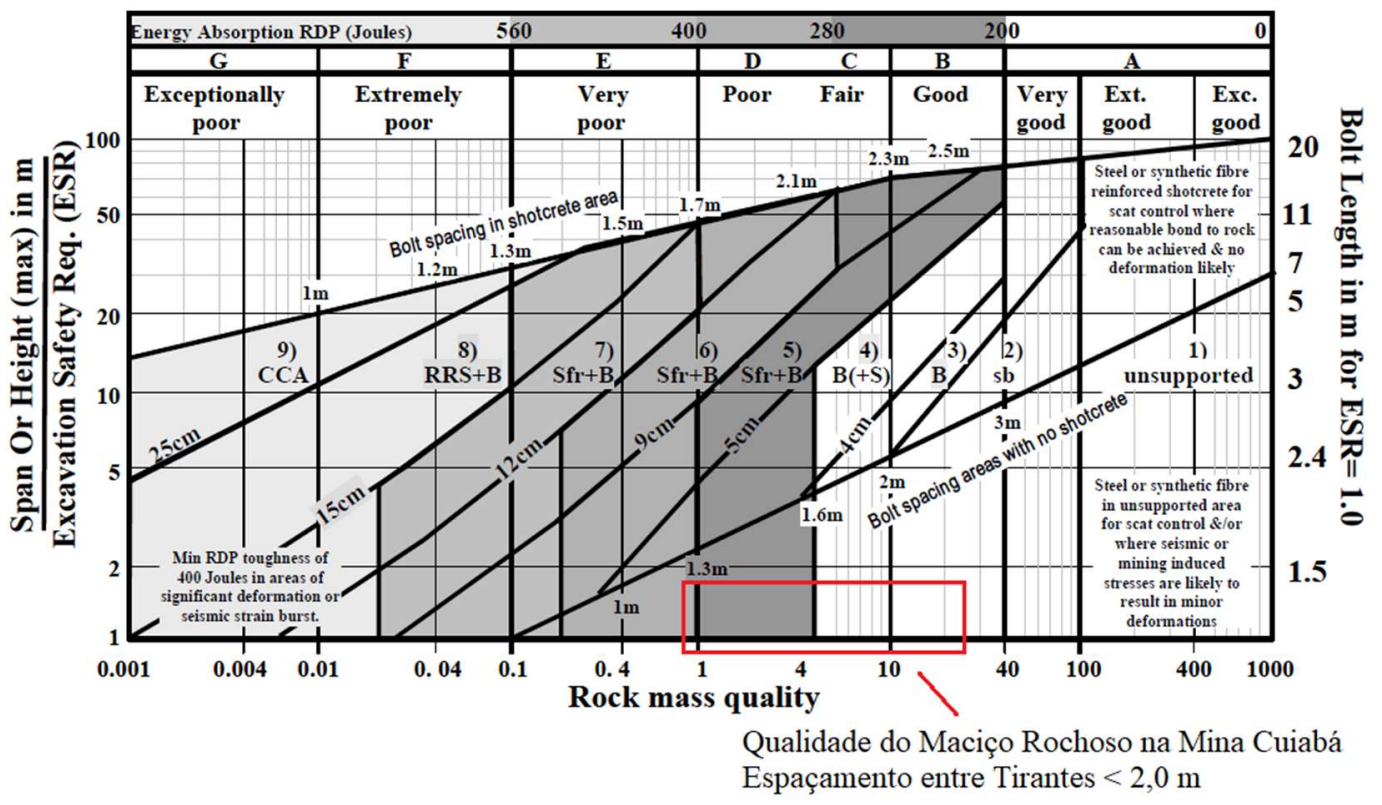

Figura 61 - Dimensionamento do sistema de suporte da mina Cuiabá a partir da classificação modificada de Papworth [48]. Adaptado de Papworth [48]

Tabela 16 - Classificação de cada região indicada na Figura 61. Adaptado de Grimstad \& Barton

\begin{tabular}{cc}
\hline Região & Sistema de Suporte \\
\hline 1 & Sem suporte \\
2 & Aplicação de tirantes locais, $\boldsymbol{s} \boldsymbol{b}$ \\
3 & Aplicação de tirantes sistematicamente, $\boldsymbol{B}$ \\
4 & Aplicação de tirantes sistematicamente e concreto projetado, $\boldsymbol{B}(+\boldsymbol{S})$ \\
5 & Concreto projetado com fibras e tirantes, $5-9 \mathrm{~cm}, \boldsymbol{S} \boldsymbol{f}+\boldsymbol{B}$ \\
6 & Concreto projetado com fibras e tirantes, $9-12 \mathrm{~cm}, \boldsymbol{S} \boldsymbol{f}+\boldsymbol{B}$ \\
7 & Concreto projetado com fibras e tirantes, $12-15 \mathrm{~cm}, \boldsymbol{S} \boldsymbol{r}+\boldsymbol{B}$ \\
8 & Concreto projetado com fibras $>15 \mathrm{~cm}$, reforço armado e tirantes, $\boldsymbol{S f r}+\boldsymbol{R} \boldsymbol{R} \boldsymbol{s}+\boldsymbol{B}$ \\
9 & Revestimento de concreto armado, $\boldsymbol{C} \boldsymbol{C A}$ \\
\hline
\end{tabular}




\subsection{3.}

\section{Influência das condições de contorno na resposta mecânica dos ensaios de flexão em painéis}

A Figura 62 apresenta os resultados dos ensaios de flexão em painéis quadrados de acordo com a norma EN 14488-5 [50] e sua comparação com as curvas obtidas para o ensaio de flexão em painéis circulares (ASTM C1550 [49]). A comparação foi feita para o concreto projetado reforçado com $4,2 \mathrm{~kg} / \mathrm{m}^{3}$ de PPF1. A Tabela 17 apresenta os resultados de tenacidade e carga máxima de ruptura para os ensaios de flexão em painéis quadrados e circulares.

Baseado nos resultados obtidos, é possível perceber maiores valores de tanto resistência residual e carga de pico quanto de tenacidade para os resultados obtidos nos ensaios de flexão em painéis quadrados. A tenacidade final do ensaio quadrado $\left(\mathrm{T}_{30}\right)$ apresentou um final por volta de 4 vezes maior que a tenacidade $\mathrm{T}_{40}$ do ensaio circular. Resultado semelhante também foi obtido por Rambo [123], que comparou o ensaio de flexão em painéis circulares com diferentes configurações de apoio. Os valores de resistência de pico e pós-pico aumentaram cada vez que as configurações de apoio se aproximaram do suporte circular contínuo, semelhante ao que ocorre entre as normas EN 14488-5 [50] e ASTM C1550 [49].

Tabela 17 - Resultados de tenacidade e carga última dos ensaios de flexão em painéis quadrados (EN 14488-5 [50]) e circulares (ASTM C1550 [49]). Desvio padrão indicado entre parênteses

\begin{tabular}{|c|c|c|c|c|c|c|c|}
\hline Composição & Norma & $\begin{array}{c}\mathrm{P}_{\mathrm{u}} \\
(\mathrm{kN})\end{array}$ & $\begin{array}{l}\mathrm{T}_{10} \\
(\mathrm{~J})\end{array}$ & $\begin{array}{l}\mathrm{T}_{20} \\
(\mathrm{~J})\end{array}$ & $\begin{array}{l}\mathrm{T}_{30} \\
(\mathrm{~J})\end{array}$ & $\begin{array}{l}\mathrm{T}_{40} \\
(\mathrm{~J})\end{array}$ & $\begin{array}{c}\text { TPL* } \\
- \\
\end{array}$ \\
\hline C4.2PPF1-P & EN 14488-5 & $\begin{array}{l}54,94 \\
(5,14)\end{array}$ & $\begin{array}{l}395,31 \\
(38,28)\end{array}$ & $\begin{array}{c}646,21 \\
(73,81)\end{array}$ & $\begin{array}{c}800,97 \\
(116,06)\end{array}$ & $\begin{array}{l}- \\
-\end{array}$ & $\begin{array}{l}\text { III } \\
\text { D }\end{array}$ \\
\hline C4.2PPF1-P & ASTM C1550 & $\begin{array}{l}31,48 \\
(0,69)\end{array}$ & $\begin{array}{l}77,70 \\
(3,94)\end{array}$ & $\begin{array}{c}131,24 \\
(4,77)\end{array}$ & $\begin{array}{c}164,94 \\
(6,47)\end{array}$ & $\begin{array}{l}188,51 \\
(9,22)\end{array}$ & $\begin{array}{l}0 \\
\mathrm{~A}\end{array}$ \\
\hline
\end{tabular}

*Índice de Performance de Tenacidade 

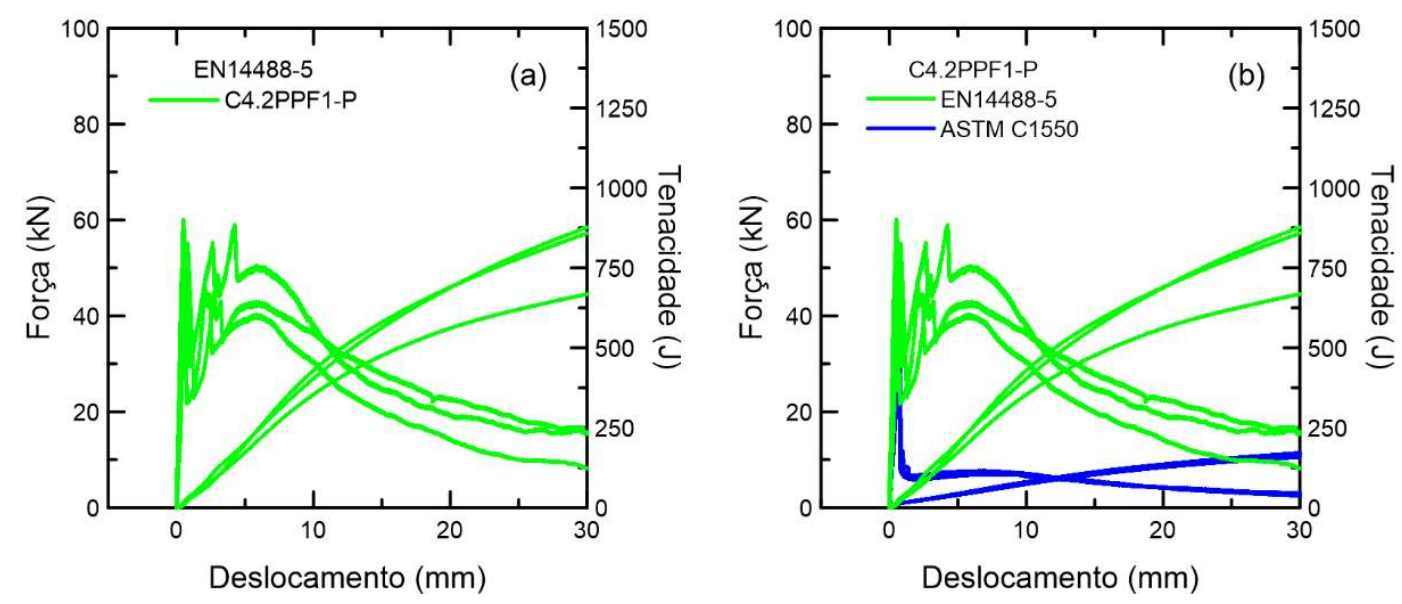

Figura 62 - Resultados dos ensaios de flexão em painéis quadrados (EN 14488-5 [50]) e circulares

(ASTM C1550 [49]) do concreto projetado reforçado com 4,2 kg/m³ de fibra PPF1. Curvas de força e tenacidade por deslocamento para (a) ensaios de painel quadrado (EN 14488-5 [50]) e (b) comparação dos ensaios em painéis circulares e quadrados

O comportamento pós-fissuração da matriz, por sua vez, também difere consideravelmente em relação às duas normas. A Figura 63 mostra a curva de força por deslocamento até $8 \mathrm{~mm}$ dos ensaios de flexão nos painéis quadrado e circular para o concreto projetado reforçado com $4,2 \mathrm{~kg} / \mathrm{m}^{3}$ de PPF1. No ensaio com apoio contínuo, é possível perceber que o surgimento de suas fissuras principais, indicadas no gráfico por I, II e III, ocorrem em momentos distintos. A primeira ocorre ainda no início do ensaio por volta $0,5 \mathrm{~mm}$, enquanto a segunda e a terceira surgem ao redor de $3 \mathrm{~mm}$ de deslocamento. Já no ensaio circular com três apoios as três fissuras ocorrem de forma praticamente simultânea no momento da ruptura da matriz cimentícia. A Figura 64 mostra o modo de ruptura dos dois ensaios analisados.

Em termos de dimensionamento, o trabalho de Papworth [48] indica maiores valores de tenacidade para os ensaios de flexão em painéis quadrados, como mostrado na Tabela 18. Por outro lado, é possível perceber uma inconsistência na classificação quanto ao índice de performance de tenacidade (TPL) para o mesmo material dependendo da norma estudada. Enquanto a adição de $4,2 \mathrm{~kg} / \mathrm{m}^{3}$ da fibra PPF1 é classificado para casos em que a qualidade da rocha é muito boa pelo ensaio pela norma ASTM C1550, a mesma fração volumétrica de PPF1 é classificada para maciços rochosos de qualidade fraca para os ensaios na EN 14488-5. Dessa maneira, mais estudos em relação ao dimensionamento do concreto projetado com fibras, como o trabalho de Papworth [48], devem ser executados para não haver 
divergências entre os dois ensaios. Como o uso dos ensaios circulares mostra um dimensionamento mais conservador, a aplicação dos ensaios pela ASTM C1550 pode ser a melhor opção visando uma maior segurança.
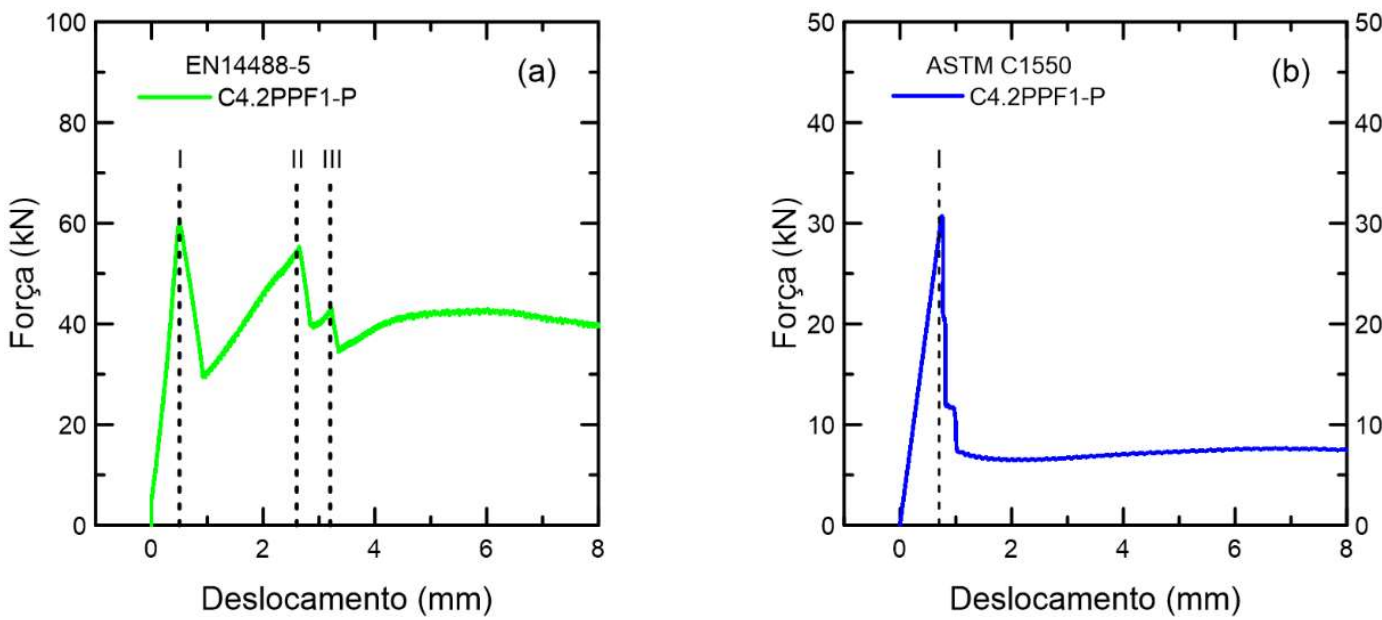

Figura 63 - Curvas de força por deslocamento até $8 \mathrm{~mm}$ para o concreto projetado reforçado com

$4,2 \mathrm{~kg} / \mathrm{m}^{3}$ de PPF1 em ensaios de flexão em painéis (a) quadrados com apoio contínuo (EN 14488-

5 [50]) e (b) circulares em três apoios rotulados (ASTM C1550 [49])

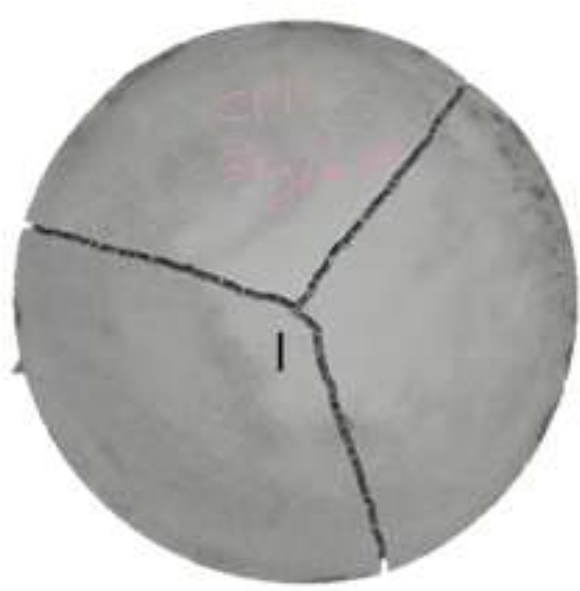

(a)

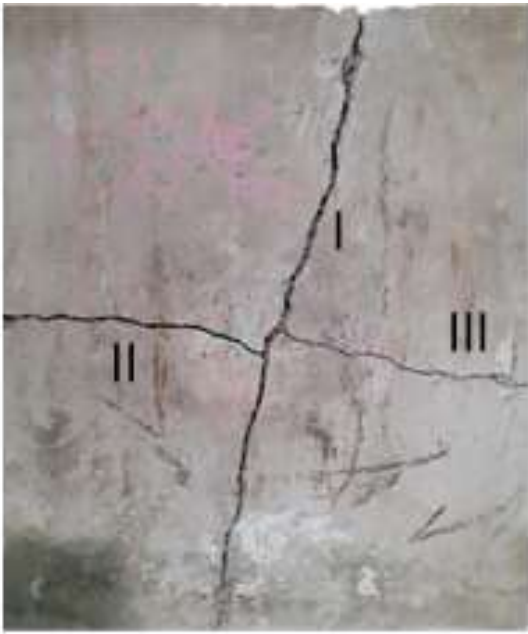

(b)

Figura 64 - Modo de ruptura dos ensaios de flexão em painéis (a) circulares em três apoios rotulados (ASTM C1550 [49]) e (b) quadrados com apoio contínuo (EN 14488-5 [50]) 
Tabela 18 - Classificação do concreto reforçado com fibras de acordo com a qualidade do maciço rochoso a partir do trabalho de Papworth [48]. Tenacidade obtida a partir de ensaios de flexão em painéis de acordo com as normas EN 14488-5 e ASTM C1550

\begin{tabular}{cccc}
\hline \multicolumn{2}{c}{ Qualidade do Maciço Rochoso } & \multicolumn{2}{c}{ Tenacidade } \\
\hline TPL* & Classe & $\begin{array}{c}\text { EN 14488-5 } \\
\text { (Joules) }\end{array}$ & $\begin{array}{c}\text { ASTM C1550 } \\
\text { (Joules) }\end{array}$ \\
\hline IV & - & $>1400$ & $>560$ \\
IV & F & $>1000$ & $>400$ \\
III & E & $>700$ & $>280$ \\
II & D & $>500$ & $>200$ \\
I & C & $>500$ & $>200$ \\
0 & B & 0 & 0 \\
\hline
\end{tabular}

*Índice de Performance de Tenacidade

\subsection{4. \\ Comportamento mecânico do concreto com fibras em ensaios de flexão em painéis de larga escala}

A Figura 65 apresenta as curvas de força e tenacidade por deslocamento para o ensaio de flexão em painel de larga escala. Foi analisado o comportamento mecânico à flexão para o concreto reforçado com $4,2 \mathrm{~kg} / \mathrm{m}^{3}$ fibras de sintéticas PPF1, que é atualmente a fração aplicada nas obras de escavação da mina Cuiabá. A Tabela 19 traz os valores de força $\mathrm{P}_{\mathrm{f}, 1}, \mathrm{P}_{\mathrm{f}, 2}$ e $\mathrm{P}_{\mathrm{f}, 3}$ correspondentes aos deslocamentos $\delta_{\mathrm{f}, 1}, \delta_{\mathrm{f}, 2}$, e $\delta_{\mathrm{f}, 3}$ ao longo do ensaio de flexão. Os deslocamentos $\delta_{\mathrm{f}, 1}$, $\delta_{\mathrm{f}, 2}$, e $\delta_{\mathrm{f}, 3}$ são correspondentes ao surgimento das três principais fissuras ao longo do ensaio. A Tabela 20 reporta os valores de tenacidade e força para diferentes níveis de deslocamento.

Como mostrado na Figura 65 e 66, o ensaio de flexão em painel de larga escala apresentou um comportamento de pós-fissuração semelhante ao que ocorre no ensaio de flexão no painel quadrado de acordo com a norma EN 14488-5 [50]. Até atingir $10 \mathrm{~mm}$ de deslocamento, a amostra expôs três fissuras principais antes do início do comportamento de softening característico do material reforçado com fibras sintéticas. A Figura 65(b) mostra os três momentos em que ocorre as três principais fissuras no gráfico e as Figura 67 e 68 apresentam o modo de ruptura do ensaio analisado. 

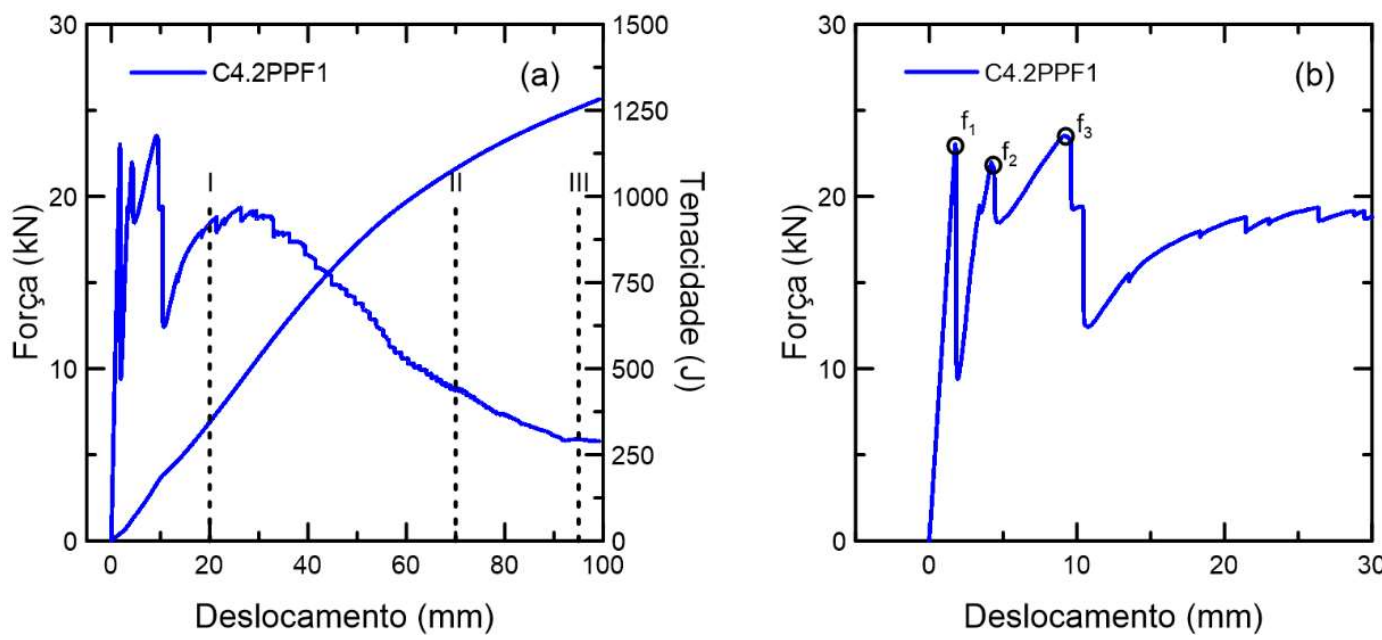

Figura 65 - Resultados do ensaio de flexão do painel de larga escala para o concreto reforçado com 4,2 kg/m³ de fibra PPF1: (a) curva de força e tenacidade e deslocamento e (b) curva de força por deslocamento até $30 \mathrm{~mm}$ de deslocamento

Tabela 19 - Valores de força $\left(\mathrm{P}_{\mathrm{f}, 1}, \mathrm{P}_{\mathrm{f}, 2}\right.$ e $\left.\mathrm{P}_{\mathrm{f}, 3}\right)$ de acordo com os deslocamentos $\left(\delta_{\mathrm{f}, 1}, \delta_{\mathrm{f}, 2}\right.$, e $\left.\delta_{\mathrm{f}, 3}\right)$ ao longo do ensaio de flexão do painel de larga escala

\begin{tabular}{ccccccc}
\hline Composição & $\begin{array}{c}\mathrm{P}_{\mathrm{f}, 1} \\
(\mathrm{kN})\end{array}$ & $\begin{array}{c}\delta_{\mathrm{f}, 1} \\
(\mathrm{~mm})\end{array}$ & $\begin{array}{c}\mathrm{P}_{\mathrm{f}, 2} \\
(\mathrm{kN})\end{array}$ & $\begin{array}{c}\delta_{\mathrm{f}, 2} \\
(\mathrm{~mm})\end{array}$ & $\begin{array}{c}\mathrm{P}_{\mathrm{f}, 3} \\
(\mathrm{kN})\end{array}$ & $\begin{array}{c}\delta_{\mathrm{f}, 3} \\
(\mathrm{~mm})\end{array}$ \\
\hline C4.2PPF1 & 22,66 & 1,80 & 21,24 & 4,40 & 23,16 & 9,57 \\
\hline
\end{tabular}

Tabela 20 - Resultados de força e tenacidade para diferentes níveis de deslocamento ao longo do ensaio de flexão do painel de larga escala

\begin{tabular}{ccccccccccc}
\hline Composição & $\begin{array}{c}\mathrm{P}_{20} \\
(\mathrm{kN})\end{array}$ & $\begin{array}{c}\mathrm{T}_{20} \\
(\mathrm{~J})\end{array}$ & $\begin{array}{c}\mathrm{P}_{40} \\
(\mathrm{kN})\end{array}$ & $\begin{array}{c}\mathrm{T}_{40} \\
(\mathrm{~J})\end{array}$ & $\begin{array}{c}\mathrm{P}_{60} \\
(\mathrm{kN})\end{array}$ & $\begin{array}{c}\mathrm{T}_{60} \\
(\mathrm{~J})\end{array}$ & $\begin{array}{c}\mathrm{P}_{80} \\
(\mathrm{kN})\end{array}$ & $\begin{array}{c}\mathrm{T}_{80} \\
(\mathrm{~J})\end{array}$ & $\begin{array}{c}\mathrm{P}_{100} \\
(\mathrm{kN})\end{array}$ & $\begin{array}{c}\mathrm{T}_{100} \\
(\mathrm{~J})\end{array}$ \\
\hline C4.2PPF1 & 18,42 & 344 & 16,59 & 711 & 10,59 & 984 & 7,34 & 1160 & 5,79 & 1283 \\
\hline
\end{tabular}

Os ensaios de flexão em larga escala apresentam valores menores de tensão residual em relação aos da norma EN 14488-5. Por outro lado, o ensaio de maior escala indica maior capacidade de deformação. Vale ressaltar que o ensaio da norma europeia é executado em amostras com maior espessura $(100 \mathrm{~mm})$ quando comparado com o ensaio de larga escala estudado $(80 \mathrm{~mm})$, fator que também ajuda promover maiores tensões de pico e residuais. 


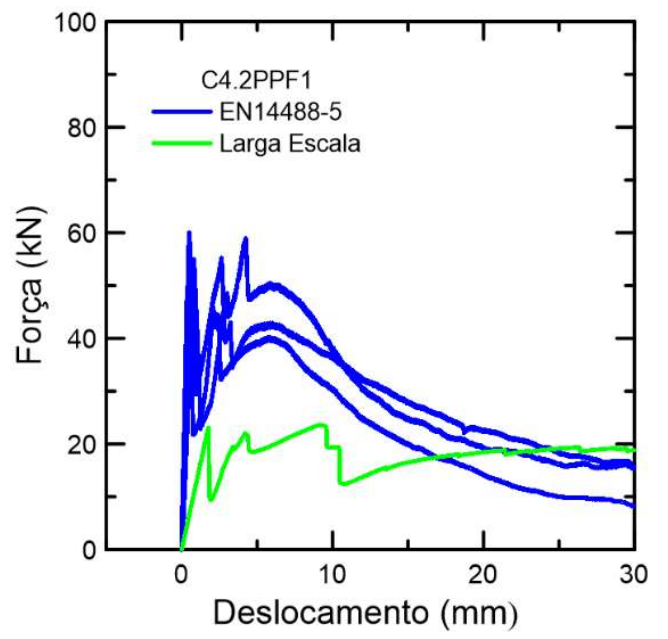

Figura 66 - Comparação do comportamento pós-fissuração do concreto reforçado com 4,2 kg/m³ de fibra PPF1 através dos ensaios em painéis de larga escala e de acordo com a norma EN 14488-5

Diferente do que ocorre em ensaios de larga escala com apoios contínuos fixos, o painel simplesmente apoiado utilizado no ensaio realizado não apresenta uma ruptura completa do material indicando o fim do ensaio. Morton [13] fez ensaios com os apoios fixos e reportou um máximo de deslocamento do material de quase $80 \mathrm{~mm}$ para uma espessura de $85 \mathrm{~mm}$ e adição de fibras sintéticas ao concreto projetado.

No resultado indicado na Figura 67, por sua vez, grandes aberturas de fissuras foram identificadas na amostra após atingir $70 \mathrm{~mm}$ de deslocamento. A Figura 67 apresenta a evolução das fissuras ao longo do ensaio e as imagens são correspondentes às linhas tracejadas indicadas na Figura 65(a) por I e II. A Figura 68 mostra a abertura de fissuras após $95 \mathrm{~mm}$ de deslocamento da amostra, indicado na Figura 65(a) por III. No modo de ruptura indicado na Figura 68(b), a amostra já apresenta fissuração completa do material com ruptura total das fibras na principal abertura de fissura indicada.

Dessa maneira, visando sua aplicação em obras de contenção de deformação do maciço rochoso, o concreto reforçado com fibras sintéticas PPF1 aparenta promover uma deformação máxima sem ruptura total do material de por volta de $70 \mathrm{~mm}$ de deslocamento. Costa et al. [106] identificou por volta de $150 \mathrm{~mm}$ de deslocamento da rocha nas regiões de maior profundidade da mina Cuiabá. Dessa maneira, a aplicação somente de concreto projetado com $4,2 \mathrm{~kg} / \mathrm{m}^{3}$ da fibra PPF1 não parece ser a solução mais viável para conter as deformações medidas. Baseado 
em outros trabalhos já realizados [13, 36, 37], mais estudos em ensaios de maior escala com uso de maiores frações volumétricas da fibra PPF1, fibras de aço e aplicação combinada de telas soldadas com concreto projetado são indicados para o caso analisado na mina presente em Sabará. Os resultados indicados também podem ser usados em futuros trabalhos de modelagem numérica com objetivo de melhor entender o comportamento mecânico de sistemas de suporte em obras de mineração.

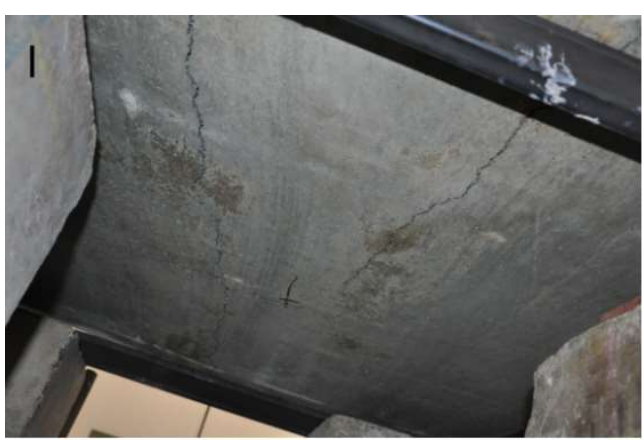

(a)

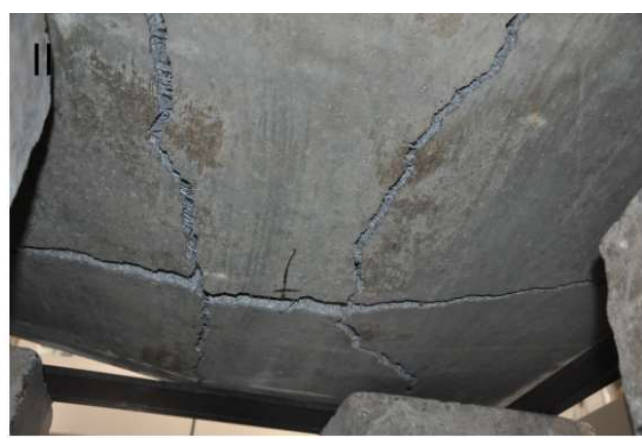

(b)

Figura 67 - Evolução da abertura de fissuras em (a) com $20 \mathrm{~mm}$ de deslocamento e (b) $70 \mathrm{~mm}$ de deslocamento. Os números I e II são correspondentes às linhas tracejadas na Figura 65(a)

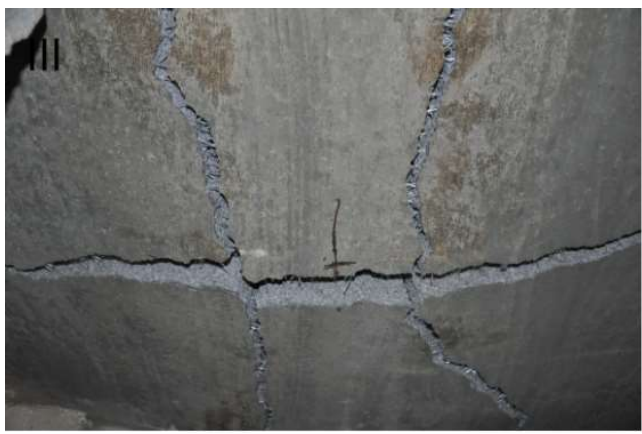

(a)

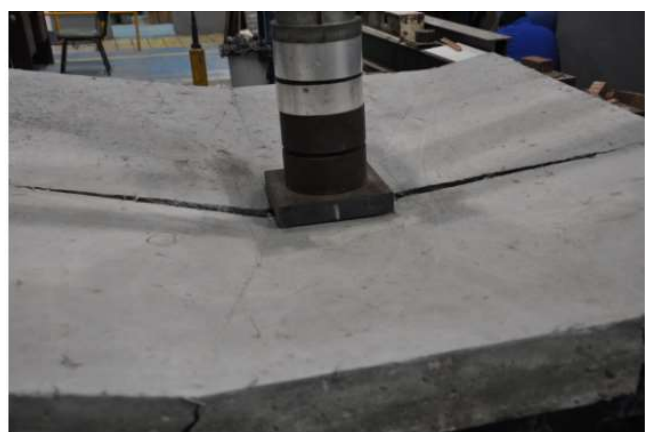

(b)

Figura 68 - Modo de fissuração do painel após $95 \mathrm{~mm}$ de deslocamento: (a) visão inferior e (b) superior das fissuras. Estado correspondente ao número III indicado na linha tracejada da Figura $65(a)$ 
5.6.

Conclusão

A partir dos ensaios de flexão em prismas, foi possível caracterizar o comportamento pós-fissuração do concreto reforçado com dois tipos de fibras sintéticas (Barchip54 e TamFib SP54) e com fibras de aço (Dramix 3D 65/35). Apesar das fibras PP analisadas apresentarem praticamente o mesmo fator forma, $\mathrm{o}$ maior módulo de elasticidade e a melhor aderência da fibra Barchip54 promoveram maiores valores de resistência residual e tenacidade para todas as frações volumétricas analisadas.

Apesar da adição de $25 \mathrm{~kg} / \mathrm{m}^{3}$ de fibra de aço apresentar valores significativamente maiores de tensão residual nos primeiros níveis de abertura de fissura, as fibras sintéticas podem ser mais eficientes em maiores deformações dependendo da fração volumétrica estudada. Isso está associado com a aderência das fibras verificado a partir dos ensaios de arrancamento. Além do aço apresentar uma maior aderência na matriz cimentícia devido a suas propriedades materiais, a presença do gancho é responsável por elevar significativamente a aderência dessa fibra em relação às fibras sintéticas. Por outro lado, como as fibras Barchip54 e TamFib SP54 possuem um alto relevo em sua superfície, à medida que a fibra é puxada da matriz cimentícia, os valores de aderência entre as fibras sintéticas e de aço se aproximam.

O concreto projetado reforçado com fibras aplicado na mina Cuiabá foi classificado de acordo com os valores de tenacidade obtidos a partir dos ensaios de flexão em painéis circulares. Cada fração volumétrica estudada da fibra TamFib SP54 acarretou em uma diferente classificação do material para obras de escavação de minas. Enquanto a adição de $4,2 \mathrm{~kg} / \mathrm{m}^{3}$ da fibra sintética é indicada para casos em que o maciço rochoso apresenta qualidade muito boa, o uso de $8 \mathrm{~kg} / \mathrm{m}^{3}$ foi associado para rochas de qualidade muito fraca. A alternativa do uso de $25 \mathrm{~kg} / \mathrm{m}^{3}$ da fibra de aço apresentou resultados equivalentes ao uso de $8 \mathrm{~kg} / \mathrm{m}^{3}$ da fibra TamFib SP54.

Em relação ao dimensionamento do sistema de suporte na mina Cuiabá, as áreas com qualidade do maciço rochoso muito fraca necessitam de uma maior fração volumétrica da fibra sintética aplicada, por volta de $6 \mathrm{~kg} / \mathrm{m}^{3}$. Já nos domínios com melhor qualidade do maciço, a aplicação de $4,2 \mathrm{~kg} / \mathrm{m}^{3}$ de PP já deve suficiente 
controlar a degradação da rocha. A aplicação de $25 \mathrm{~kg} / \mathrm{m}^{3}$ de fibra de aço e $8 \mathrm{~kg} / \mathrm{m}^{3}$ de fibra sintética são indicados somente em casos que rochas de qualidade muito fraca, caso que não foi observado pelos estudos prévios dos engenheiros presentes na mina. As frações mais baixas de fibra de aço $\left(<30 \mathrm{~kg} / \mathrm{m}^{3}\right)$ são mais indicadas em locais de menores deformações já que apresentam uma queda significativa nas tensões residuais após os primeiros níveis de deslocamento, como mostrado nos ensaios de flexão em prismas e dos ensaios de arrancamento. Por outro lado, a adição de frações maiores das fibras metálicas, como $40 \mathrm{~kg} / \mathrm{m}^{3}$ ou $60 \mathrm{~kg} / \mathrm{m}^{3}$, podem melhorar a performance mecânica nas grandes deformações e é uma alternativa a ser estudada.

Os ensaios de flexão em painéis circulares e quadrados, apesar de serem usados para analisar o concreto projetado com fibras, eles apresentam algumas diferenças no comportamento pós-fissuração. Essas diferenças estão associadas principalmente devido às condições de contorno aplicadas para cada norma. Para o ensaio de flexão em painel circular com três apoios rotulados, as três fissuras ocorrem de maneira simultâneas com um comportamento do tipo softening imediatamente após atingir o pico. Já para o painel quadrado com apoio contínuo, as fissuras perpendiculares ocorrem em momentos distintos do ensaio, além de apresentar valores de resistência e tenacidade pós-pico muito maiores em relação ao ensaio circular.

Foi possível observar uma divergência no dimensionamento realizado a partir dos ensaios de flexão quadrados (EN 14488-5) e circulares (ASTM C1550). A classificação para a mesma fração de $4,2 \mathrm{~kg} / \mathrm{m}^{3}$ de fibra sintética TamFib SP54 foi diferente dependendo da norma aplicada. Isso mostra que mais pesquisas na interseção entre os ensaios de flexão e sua aplicação nas obras de mineração ainda devem ser feitos. Como os resultados obtidos nos ensaios de flexão em painéis circulares foram mais conservadores, eles devem apresentar um dimensionamento visando uma maior segurança.

Por fim, através do ensaio de flexão em painel de larga escala, foi possível analisar o comportamento pós-fissuração do material visando sua aplicação em obras de mineração. Semelhante ao apresentado no ensaio de flexão em painéis quadrados pela norma europeia, a amostra a apresentou a presença de três fissuras principais antes do início do softening com a queda da capacidade resistente. A adição de 4,2 kg/m³ de fibra sintética TamFib SP54, que é utilizada na mina Cuiabá, 
atingiu o deslocamento de $70 \mathrm{~mm}$ já com total abertura de sua principal fissura. Dessa maneira, pensando no uso do material para contenção das deformações rochosas, estima-se que uma capacidade máxima por volta de $70 \mathrm{~mm}$ de deslocamento do concreto reforçado com $4,2 \mathrm{~kg} / \mathrm{m}^{3}$ da fibra TamFib SP54. Valor ainda abaixo dos $150 \mathrm{~mm}$ medidos em grandes profundidades da mina Cuiabá. Mais estudos de sistemas de suporte em ensaios de larga escala são necessários para um melhor entendimento do comportamento do mecânico quando submetidos a grandes deslocamentos. 


\section{6 \\ Controle de qualidade do concreto com fibras através do ensaio de duplo puncionamento}

6.1.

Introdução

O controle de qualidade do concreto reforçado com fibras é feito principalmente através de ensaios de flexão em prismas caracterizado pela alta variação dos resultados [83]. Além disso, amostras relativamente pesadas e o complexo procedimento experimental tornam os ensaios de flexão inadequados para o controle tecnológico do material in situ. O ensaio de duplo puncionamento, portanto, vem como alternativa aos ensaios em prismas para a análise da resistência residual e tenacidade do concreto reforçado com fibras.

Por outro lado, o ensaio de Barcelona apresenta uma grande instabilidade póspico devido principalmente à alta resistência da matriz em relação à resistência residual. A substituição dos sistemas open-loop pelo controle closed-loop consegue promover uma redução dessa instabilidade para o ensaio de tração indireta analisado [96]. Por outro lado, pouco ainda foi estudado em relação à influência da rigidez, do tipo de máquina e controle tanto na instabilidade pós-fissuração da matriz cimentícia quanto nas propriedades de interesse do concreto reforçado com fibras: tenacidade e resistência pós-fissuração.

O Capítulo 6, por sua vez, traz um estudo do ensaio de Barcelona quando realizado em diferentes tipos de máquinas de ensaio universal. Quatro diferentes máquinas servo-hidráulicas e eletromecânicas com diferentes rigidezes foram utilizadas para esse trabalho. Além disso, comparou-se o ensaio de duplo puncionamento quando realizado com o controle externo através da corrente extensométrica e pelo controle de deslocamento do atuador. $\mathrm{O}$ concreto projetado analisado foi dosado para a aplicação na escavação da mina Cuiabá e foi reforçado com fibras de aço e sintéticas. Por fim, estudou-se também a influência da rigidez das máquinas nas correlações entre o ensaio de duplo puncionamento e os ensaios de flexão em três pontos. 
6.2.

Programa experimental

A nomenclatura dos compósitos segue o mesmo padrão já explicado na seção 5.2. As mesmas fibras utilizadas para a análise do comportamento mecânico através em ensaios de flexão em prismas e painéis foram também usadas o estudo do controle de qualidade (TamFib SP54 e Dramix 3D 65/35). As dosagens adotadas para esse trabalho foram as seguintes: $4,2 \mathrm{~kg} / \mathrm{m}, 25 \mathrm{~kg} / \mathrm{m}^{3}, 40 \mathrm{~kg} / \mathrm{m}^{3}$ e $60 \mathrm{~kg} / \mathrm{m}^{3}$. Tabela 21 apresenta um resumo do programa experimental.

Tabela 21 - Programa experimental realizado a fim de estudar o controle de qualidade do concreto com fibras

\begin{tabular}{|c|c|c|c|}
\hline \multirow[b]{2}{*}{$\begin{array}{l}\text { Ensaio de duplo puncionamento } \\
\text { (Barcelona) }\end{array}$} & TamFib SP54 & $4,2 \mathrm{~kg} / \mathrm{m}^{3}$ & C4.2PPF1 \\
\hline & Dramix 3D 65/35 & $\begin{array}{l}25 \mathrm{~kg} / \mathrm{m}^{3} \\
40 \mathrm{~kg} / \mathrm{m}^{3} \\
60 \mathrm{~kg} / \mathrm{m}^{3}\end{array}$ & $\begin{array}{l}\text { C25SF } \\
\text { C40SF } \\
\text { C60SF }\end{array}$ \\
\hline \multirow{2}{*}{ Ensaios de flexão em prismas } & TamFib SP54 & $4,2 \mathrm{~kg} / \mathrm{m}^{3}$ & C4.2PPF1 \\
\hline & Dramix 3D 65/35 & $25 \mathrm{~kg} / \mathrm{m}^{3}$ & $\mathrm{C} 25 \mathrm{SF}$ \\
\hline
\end{tabular}

6.3.

\section{Fabricação das amostras}

As amostras foram fabricadas de acordo com os procedimentos de moldagem descritos na seção 4.3. No caso dos corpos de prova prismáticos produzidos para a realização dos ensaios de flexão nos prismas, todo o procedimento de fabricação já foi descrito na seção 5.3.

Para a realização dos ensaios de duplo puncionamento, as amostras foram obtidas a partir da extração de testemunhos de prismas previamente moldados para os ensaios de flexão em prismas ( 150 x 150 x $550 \mathrm{~mm})$. Primeiro, foram realizadas extrações dos cilindros com diâmetros de $100 \mathrm{~mm}$ e altura de $150 \mathrm{~mm}$. Em seguida, os testemunhos foram cortados mantendo a relação altura/diâmetro igual a um. Os cilindros foram extraídos com a utilização de um sistema de perfuração diamantado de alta resistência da Hilti ${ }^{\circledR}$. A Figura 69 mostra o processor de extração e corte das amostras. 


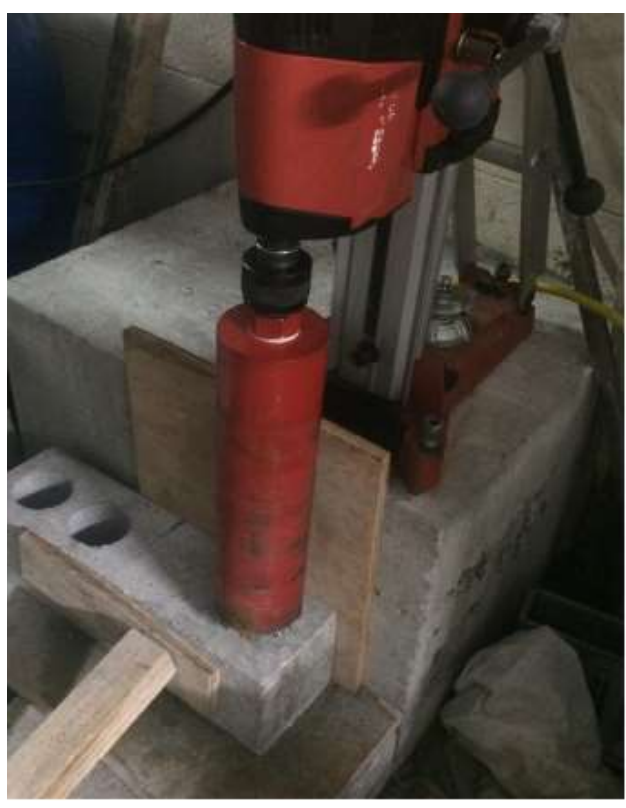

(a)

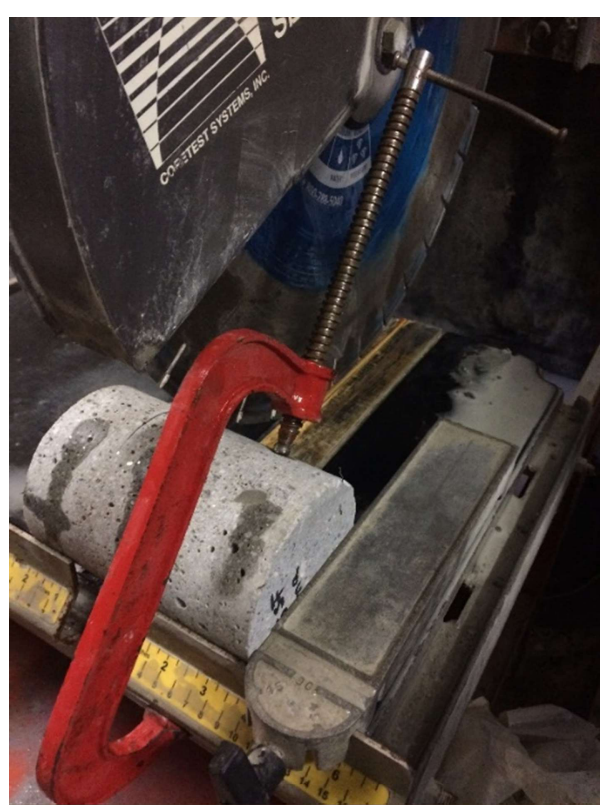

(b)

Figura 69 - Extração do corpos de prova com sistema de perfuração diamantado: (a) extração de

prismas moldados no laboratório e (b) corte dos cilindros mantendo a relação diâmetro/altura igual a um

6.4.

Ensaios mecânicos

\subsection{1.}

\section{Ensaio de duplo puncionamento}

O ensaio de duplo puncionamento para medir indiretamente a resistência à tração do concreto foi realizado em corpos de prova cilíndricos mantendo relação altura/diâmetro igual a 1, como explicado na norma espanhola UNE 83515 [76]. Os ensaios foram realizados em testemunhos extraídos com $100 \mathrm{~mm}$ de diâmetro.

O teste realiza um duplo puncionamento com dois discos de carga, centralizados no topo e no fundo do testemunho. A norma estabelece uma proporção de 1:4 entre o diâmetro do disco de carga e o diâmetro do corpo de prova $(D / 4=a)$ e $1: 5$ entre suas alturas $(H / 5=h)[76]$.

Os ensaios foram realizados com dois tipos diferentes de controle. $\mathrm{O}$ ensaio de duplo puncionamento foi executado com controle fechado (closed-loop) de deslocamento do atuador a uma velocidade de $0,50 \mathrm{~mm} / \mathrm{min}$ e o aumento do 
perímetro circunferencial ou TCOD (Total Circunferencial Opening Displacement) foi medido através de uma corrente extensométrica posicionada no perímetro central da amostra conforme indicado na norma espanhola.

O ensaio de Barcelona também foi executado com controle fechado (closedloop) pela corrente extensométrica a uma taxa de $0,05 \mathrm{~mm} / \mathrm{min}$ até atingir um valor de $T C O D$ de $0,50 \mathrm{~mm}$. Em seguida, uma taxa de 0,20 $\mathrm{mm} / \mathrm{min}$ com controle fechado pela corrente extensométrica foi aplicada até atingir o fim do ensaio com 4,5 mm de deslocamento. As Tabelas 22 e 23 resumem os dois tipos de sistema de controle usados: a configuração I trata do controle fechado pelo deslocamento do atuador e a configuração II está associada ao controle fechado pela corrente extensométrica. A Figura 70 ilustra a ensaio de duplo puncionamento realizado para o corpo de prova com $100 \mathrm{~mm}$ de diâmetro.

Duas correntes extensométrica diferentes foram utilizadas para medir o aumento do perímetro circunferencial dos copos de prova. A primeira realizava a aquisição de dados através de LVDT modelo HBM WI/5mm-T. Já a segunda media o TCOD de através de um clip-gauge modelo MTS 632.92H-03.

Tabela 22 - Configuração I: ensaios de duplo puncionamento realizados com controle fechado de deslocamento do atuador

\begin{tabular}{ccc}
\hline \multirow{2}{*}{ Configuração I Taxa de Deslocamento do Atuador } & intervalo TCOD \\
\cline { 2 - 3 } & $0,50(\mathrm{~mm} / \mathrm{min})$ & $0-6(\mathrm{~mm})$ \\
\hline
\end{tabular}

Tabela 23 - Configuração II: ensaio de duplo puncionamento realizado com controle fechado pela corrente extensométrica

\begin{tabular}{ccc}
\hline \multirow{3}{*}{ Configuração II } & Taxa TCOD & Intervalo TCOD \\
\cline { 2 - 3 } & $0,02(\mathrm{~mm} / \mathrm{min})$ & $0-0,20(\mathrm{~mm})$ \\
& $0,20(\mathrm{~mm} / \mathrm{min})$ & $0,20-4,5(\mathrm{~mm})$ \\
\hline
\end{tabular}




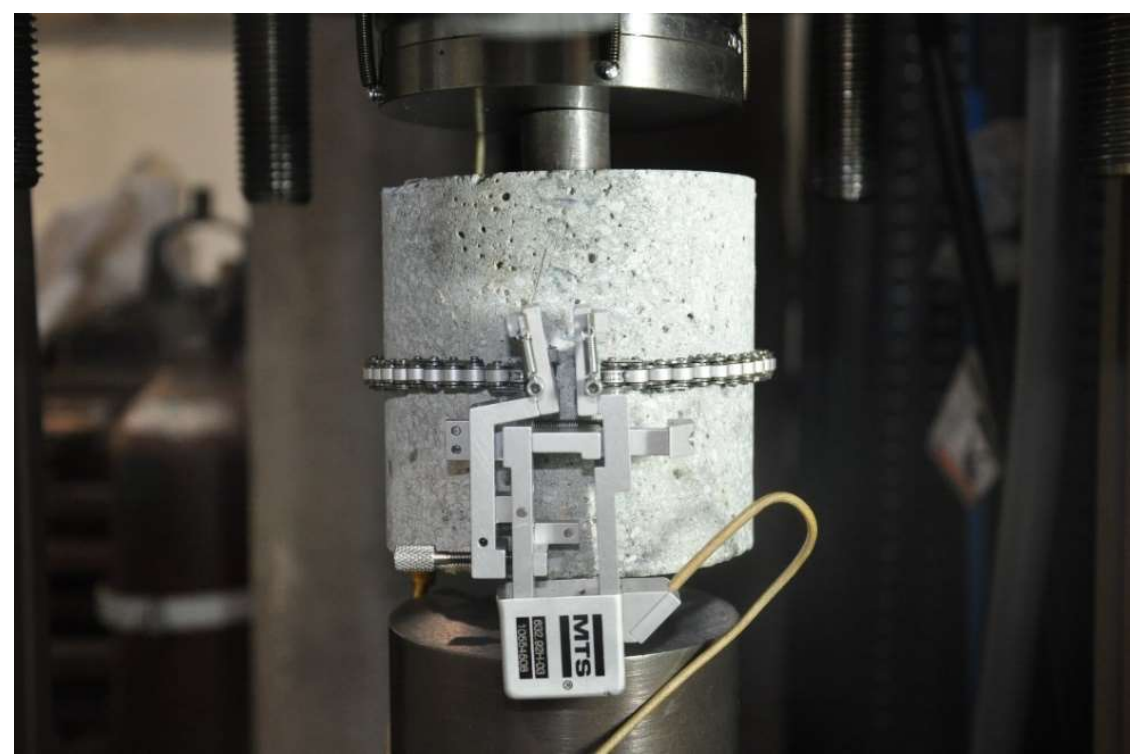

Figura 70 - Ensaio de duplo puncionamento na MTS815/315.02

A energia dissipada ao longo do ensaio de duplo puncionamento está associada à área sob a curva obtida a partir do ensaio e pode ser calculada de acordo com a Equação 7. Já a tensão de tração residual correspondente a um aumento circunferencial $R_{x}$ pode ser obtido a partir da Equação 8.

$$
\begin{aligned}
& E_{B C N, X}=\int_{0}^{X} P(T C O D) d(T C O D) \\
& f_{c t, R x}=\frac{4 P_{R, x}}{9 \pi a H}
\end{aligned}
$$

onde $a$ e $H$ são as dimensões do diâmetro do disco de carga e a altura da amostra de concreto.

\subsection{2.}

\section{Máquinas de ensaio universal}

Quatro máquinas de ensaio universal foram utilizadas para a realização do ensaio de duplo puncionamento. Os ensaios foram executados em três modelos distintos de máquinas servo-hidráulicas da fabricante MTS com controle do tipo closed-loop: MTS810/318.25, MTS311.32 e MTS815/315.02. Todos os ensaios nas máquinas servo-hidráulicas foram realizados com controlador MTS FlexTest 60 com velocidade de $6 \mathrm{kHz}$. Os testes também foram realizados em uma máquina de eletromecânica da fabricante INSTRON com controle do tipo fechado (closed- 
loop): INSTRON5582. A INSTRON5582 possui um controlador próprio. As informações de rigidez $(\mathrm{K})$, tipo de máquina e capacidade da célula de carga utilizada podem ser observados na Tabela 24 e foram fornecidas a partir dos respectivos fabricantes. Um modelo de como calcular a rigidez das máquinas pode ser analisado no apêndice. As Figuras 71 e 72 trazem o ensaio de Barcelona sendo executado em cada tipo de máquina analisada. A Figura 73 mostra todas as máquinas utilizadas.

Tabela 24 -Especificações das máquinas de ensaio universal de acordo com os fabricantes

\begin{tabular}{cccc}
\hline Modelo & Tipo & Capacidade & Rigidez (K) \\
- & - & $\mathrm{kN}$ & $\mathrm{N} / \mathrm{m}$ \\
\hline MTS810/318.25 & Servo-Hidráulica & 250 & $4,3 \times 10^{8}$ \\
MTS311.32 & Servo-Hidráulica & 1200 & $21 \times 10^{8}$ \\
MTS815/315.02 & Servo-Hidráulica & 2700 & $90 \times 10^{8}$ \\
INSTRON5582 & Eletromecânica & 100 & $2,5 \times 10^{8}$ \\
\hline
\end{tabular}

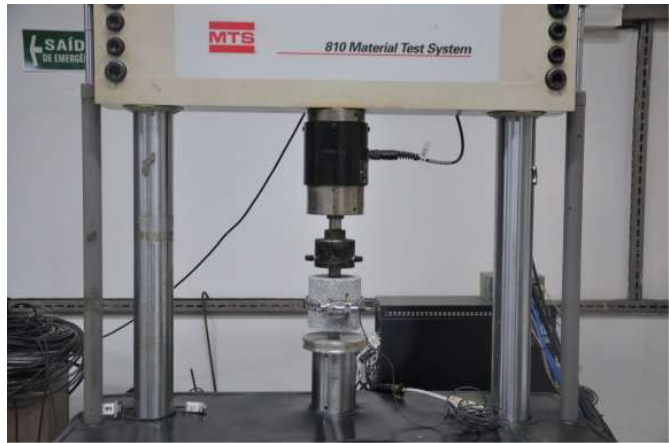

(a)

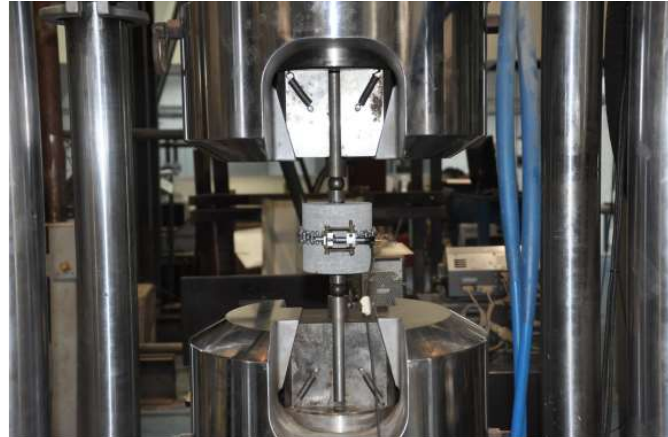

(b)

Figura 71 - Ensaio de duplo puncionamento sendo executado nas seguintes máquinas de ensaio universal: (a) MTS810/318.25 e (b) MTS311.32 


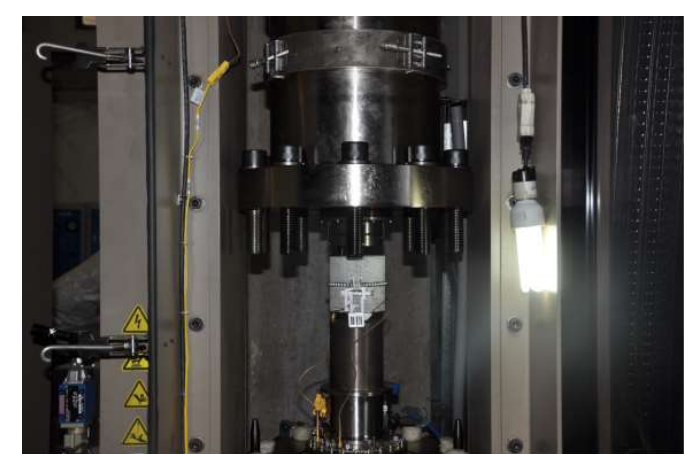

(a)

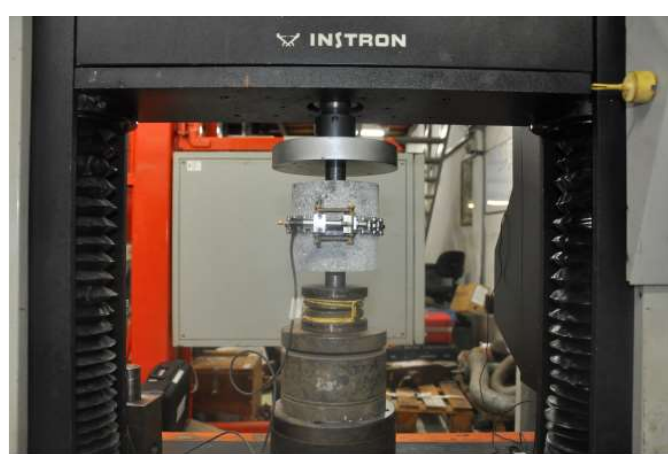

(b)

Figura 72 - Ensaio de duplo puncionamento sendo executado nas seguintes máquinas de ensaio universal: (a) MTS815/315.02 e (b) INSTRON5582

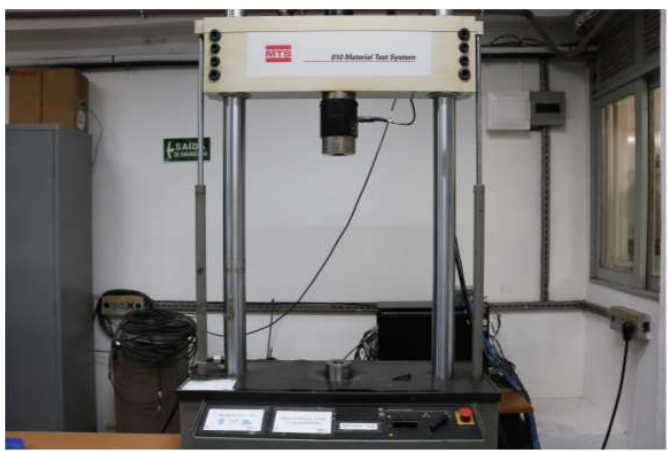

(a)

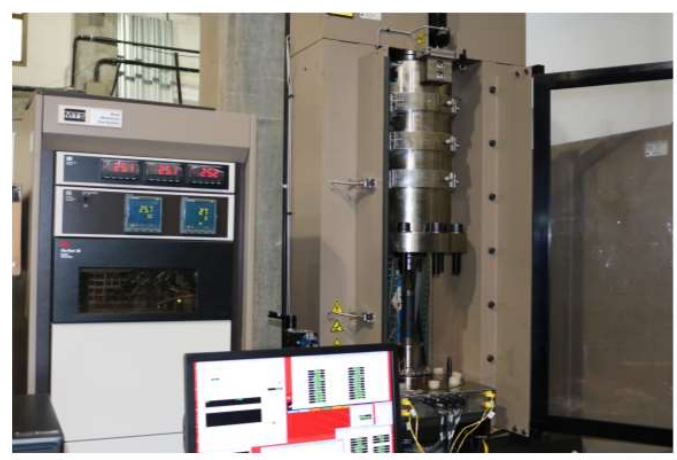

(c)

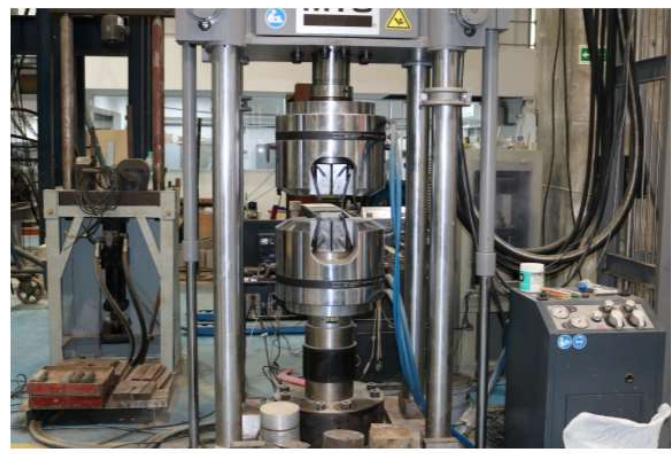

(b)

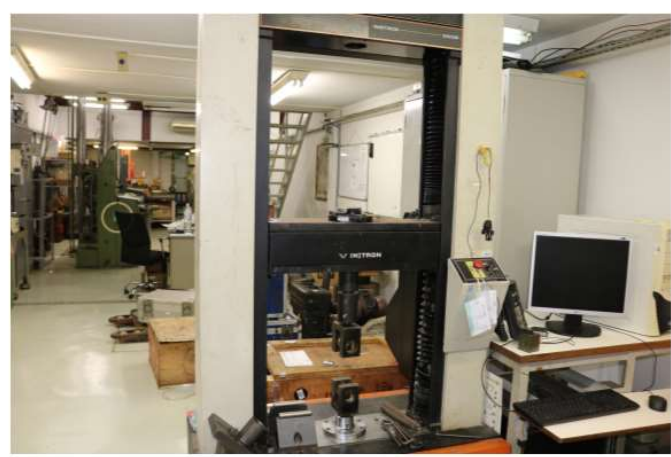

(d)

Figura 73 - Máquinas de ensaio utilizadas para a análise do ensaio de duplo puncionamento: (a) MTS810/318.25, (b) MTS311.32, (c) MTS815/315.02 e (d) INSTRON5582 


\section{5.}

\section{Resultados e discussões}

\subsection{1.}

Influência da rigidez da máquina de testes universais na extensão da instabilidade pós-pico e nas propriedades mecânicas do concreto reforçado com fibras

A Figura 74 apresenta os resultados obtidos dos ensaios de duplo puncionamento aplicados em diferentes máquinas de ensaio universal para o concreto reforçado com 4,2 kg/m³ de PPF1 e $25 \mathrm{~kg} / \mathrm{m}^{3}$ de SF. A Tabela 25 apresenta os valores médios de instabilidade pós-pico para cada caso analisado.

Baseado nos resultados obtidos, é possível observar uma diminuição significativa da instabilidade pós-pico nas máquinas de ensaio universal de maior rigidez. A variação é mais expressiva ao comparar a MTS815/315.02 e a INSTRON5582 com 310\% para C4.2PPF1 e 347\% para C25SF. Dessa maneira, máquinas de maior rigidez são mais eficientes para conter a expansão repentina da amostra no momento que a carga de fissuração é atingida. A extensão da instabilidade pós-fissuração é significativamente maior com o uso das fibras sintéticas, devido ao seu menor módulo de elasticidade e aderência em relação às fibras de aço. Essa diferença entre as fibras também foi observada por Simão et al. [96].

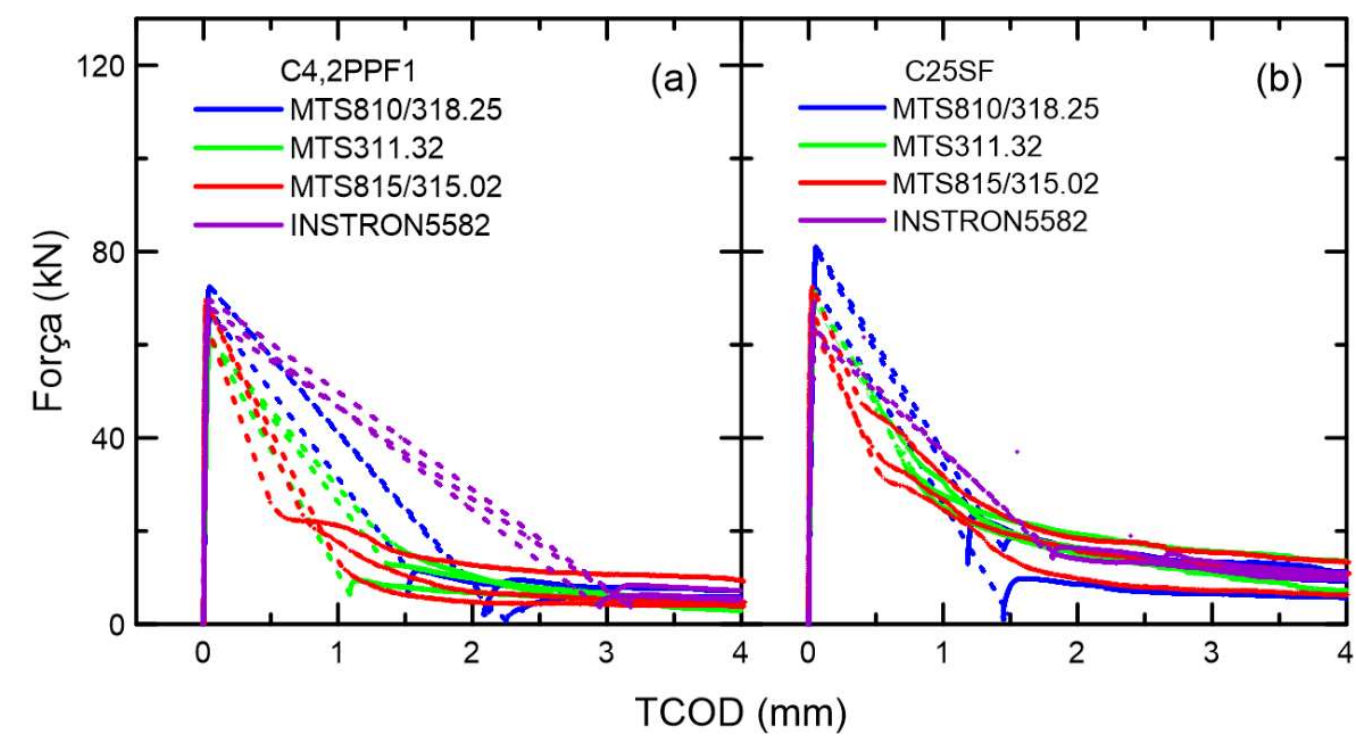

Figura 74 - Curvas de força por $T C O D$ obtidas do ensaio de duplo puncionamento realizado em diferentes máquinas de ensaio universal para o concreto reforçado com (a) $4,2 \mathrm{~kg} / \mathrm{m}^{3} \mathrm{de}$ PPF1 e (b) 
Tabela 25 - Resultados médios de instabilidade pós-pico média obtidos a partir do ensaio de duplo puncionamento realizado em diferentes máquinas de ensaio universal para o concreto reforçado com 4,2 kg/m³ de PPF1 e $25 \mathrm{~kg} / \mathrm{m}^{3}$ de SF. Desvio padrão entre parênteses

\begin{tabular}{ccccc}
\hline \multirow{4}{*}{ Composição } & \multicolumn{4}{c}{ Instabilidade Pós-Pico } \\
\cline { 2 - 5 } & $\begin{array}{c}\text { MTS810/318.25 } \\
(\mathrm{mm})\end{array}$ & $\begin{array}{c}\text { MTS311.32 } \\
(\mathrm{mm})\end{array}$ & $\begin{array}{c}\text { MTS815/315.02 } \\
(\mathrm{mm})\end{array}$ & $\begin{array}{c}\text { INSTRON5500R } \\
(\mathrm{mm})\end{array}$ \\
\hline \multirow{2}{*}{ C4.2PPF1 } & 1,79 & 1,18 & 0,70 & 2,87 \\
& $(0,30)$ & $(0,14)$ & $(0,22)$ & $(0,15)$ \\
C25SF & 1,19 & 0,56 & 0,44 & 1,97 \\
& $(0,19)$ & $(0,12)$ & $(0,05)$ & $(0,33)$ \\
\hline
\end{tabular}

A Figura 75 mostra a variação da instabilidade de acordo com o aumento de rigidez de cada máquina de ensaio universal estudada para o concreto reforçado com as duas fibras estudadas. É possível perceber que a queda no valor de instabilidade ocorre de maneira mais acelerada até atingir a rigidez equivalente à MTS311.32 $\left(21 \times 10^{8} \mathrm{~N} / \mathrm{m}\right)$. Por outro lado, a variação da instabilidade é significativamente menor desse ponto até atingir $90 \times 10^{8} \mathrm{~N} / \mathrm{m}$, que é a rigidez da

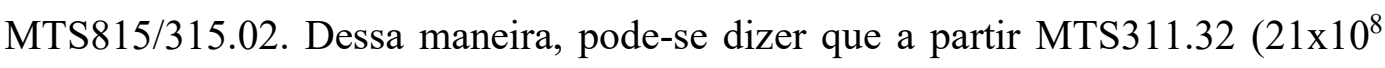
$\mathrm{N} / \mathrm{m}$ ) começa a haver uma estabilização da instabilidade pós-fissuração observada no concreto reforçado com fibras estudado. Essa queda é especialmente drástica no caso das fibras sintéticas, devido a suas propriedades materiais e sua aderência na matriz cimentícia, como comentado na seção 5.5.1.

Uma análise semelhante foi realizada para avaliar a tenacidade total do ensaio de Barcelona nas diferentes máquinas analisadas. A capacidade de absorção de energia foi calculada levando em consideração a área relativa à instabilidade pósfissuração observada para cada caso estudado. A variação da tenacidade em função da rigidez e das máquinas está reportada na Tabela 26 e na Figura 76. Há uma queda significativa nos valores de tenacidade com o aumento de rigidez das maquinas. Essa queda está associada principalmente com a diminuição da instabilidade, que acarreta em menores valores de área sobre a curva e, consequentemente, na tenacidade. A diminuição é mais expressiva no caso do concreto reforçado com fibras sintéticas, que mostrou uma variação de aproximadamente $46 \%$ entre as máquinas de maior e menor rigidez. No caso da adição das fibras de aço, a variação foi de $18 \%$ na capacidade de absorção de energia do material entre as INSTRON5582 e a MTS815/315.02. Dessa maneira, a tenacidade para um mesmo 
teor de fibras muda significativamente dependendo da rigidez da máquina escolhida para a execução do duplo puncionamento.

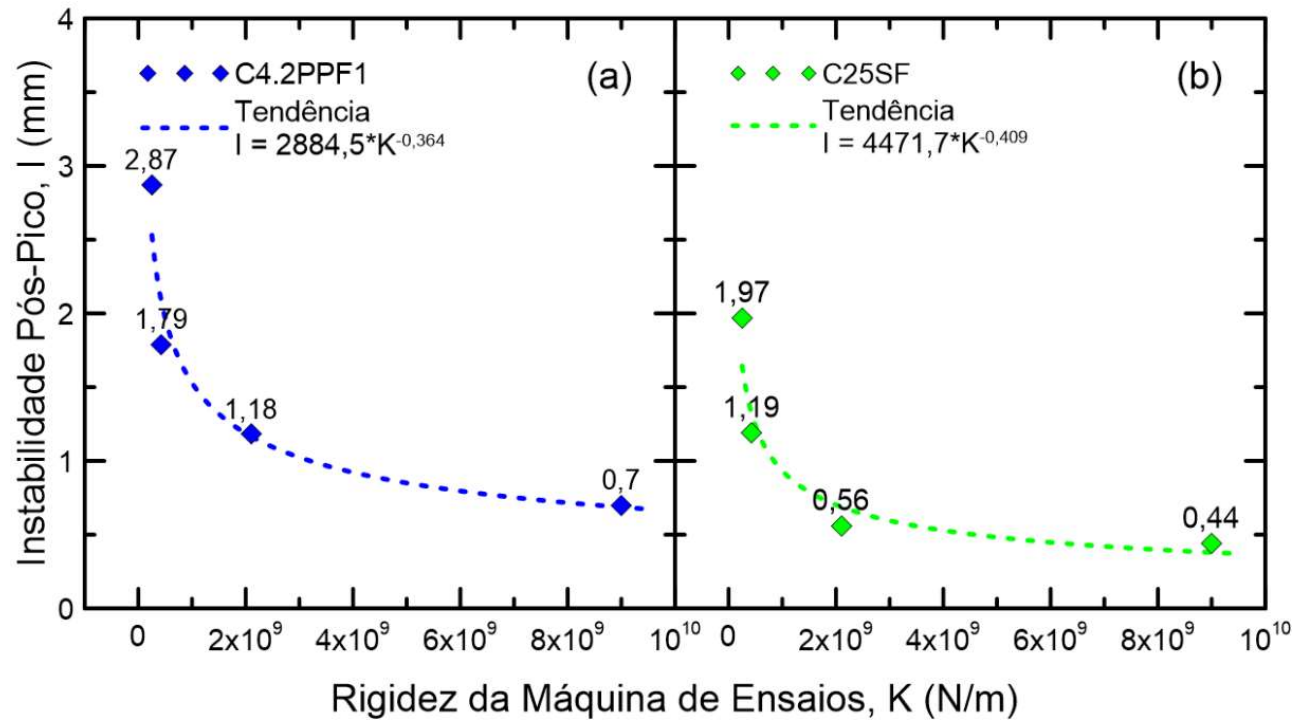

Figura 75 - Variação da instabilidade pós-pico de acordo com o aumento da rigidez da máquinas de ensaio universal estudadas no caso do concreto reforçado com (a) 4,2 kg/m³ de PPF1 e (b) 25 $\mathrm{kg} / \mathrm{m}^{3}$ de SF

Tabela 26 - Resultados médios de tenacidade em $4 \mathrm{~mm}$ de $T C O D\left(\mathrm{E}_{\mathrm{BCN}, 4.0}\right)$ obtidos a partir do ensaio de duplo puncionamento realizado em diferentes máquinas de ensaio universal para o concreto reforçado com 4,2 kg/m³ de PPF1 e $25 \mathrm{~kg} / \mathrm{m}^{3}$ de SF. Desvio padrão entre parênteses

\begin{tabular}{ccccc}
\hline \multirow{4}{*}{ Composição } & \multicolumn{4}{c}{ ECN,4.0 } \\
\cline { 2 - 5 } & MTS810/318.25 & MTS311.32 & MTS815/315.02 & INSTRON5582 \\
& $(\mathrm{J})$ & $(\mathrm{J})$ & $(\mathrm{J})$ & $(\mathrm{J})$ \\
\hline \multirow{2}{*}{ C4.2PPF1 } & 89,19 & 66,59 & 62,61 & 117,42 \\
& $(9,29)$ & $(9,75)$ & $(6,46)$ & $(6,64)$ \\
\multirow{2}{*}{ C25SF } & 94,34 & 93,81 & 86,44 & 105,08 \\
& $(17,48)$ & $(6,97)$ & $(16,16)$ & $(19,54)$ \\
\hline
\end{tabular}

A última propriedade mecânica a ser avaliada é a variação da resistência pósfissuração, que pode ser analisada em função das diferentes máquinas na Figura 77 e na Tabela 27 em diferentes níveis de TCOD. Nesse caso, a influência da rigidez na resistência pós-fissuração está mais associada aos resultados de força residual em 0,5 mm e 1,5 mm níveis de TCOD. Em geral, houve uma maior dispersão nos valores de $P_{R, 0.5}$ e $P_{R, 1.5}$, com menores resultados das duas resistências residuais para 
as máquinas com maior rigidez. Os valores de força pós-pico acima de $3 \mathrm{~mm}$, por outro lado, já apresentam menor variação com o tipo de máquina. Esse fato pode ser explicado pelo fim da instabilidade pós-fissuração por volta dos $2 \mathrm{~mm}$ de expansão radial, seguindo pela fase de softening que é comandada pela ação das fibras presentes na amostra. Como os corpos de prova apresentavam a mesma quantidade de fibras, é de se esperar valores de força pós-pico próximos.

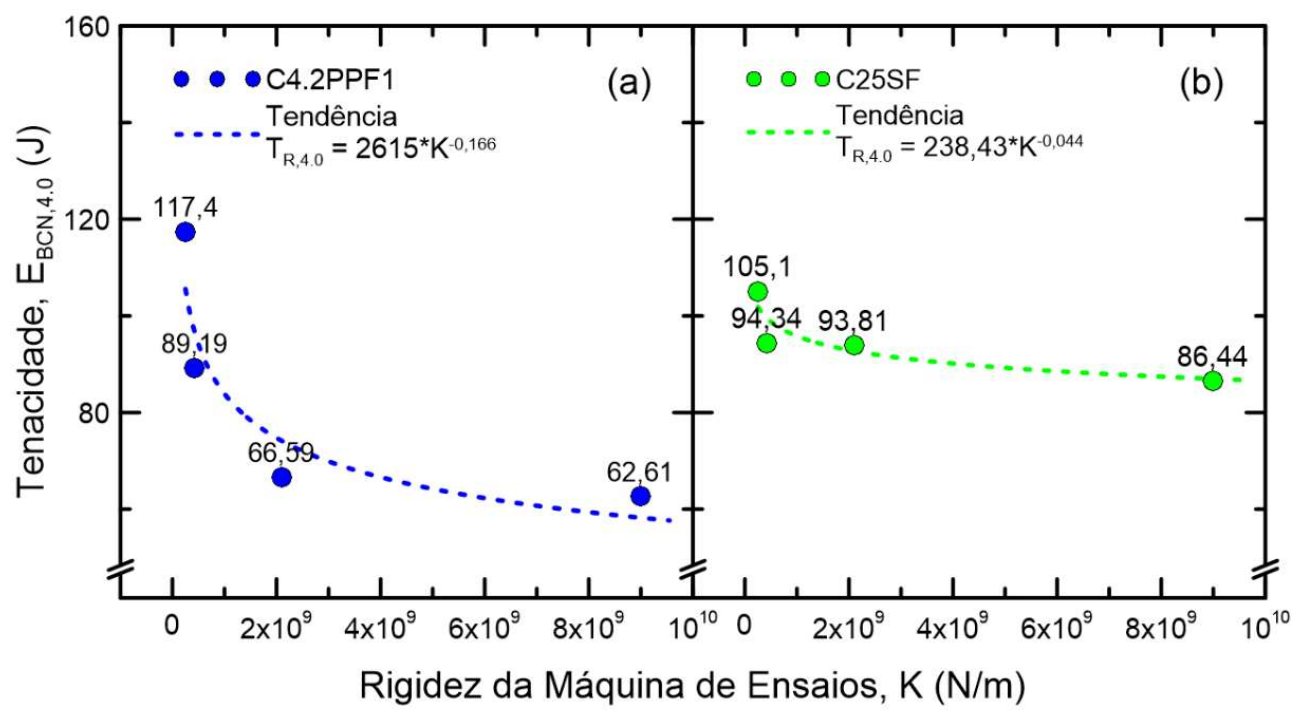

Figura 76 - Variação da tenacidade em $4 \mathrm{~mm}$ de $\operatorname{TCOD}\left(\mathrm{E}_{\mathrm{BCN}, 4.0}\right)$ com o aumento da rigidez da máquinas de ensaio universal estudadas no caso do concreto reforçado com (a) $4,2 \mathrm{~kg} / \mathrm{m}^{3}$ de PPF1 e (b) $25 \mathrm{~kg} / \mathrm{m}^{3}$ de SF

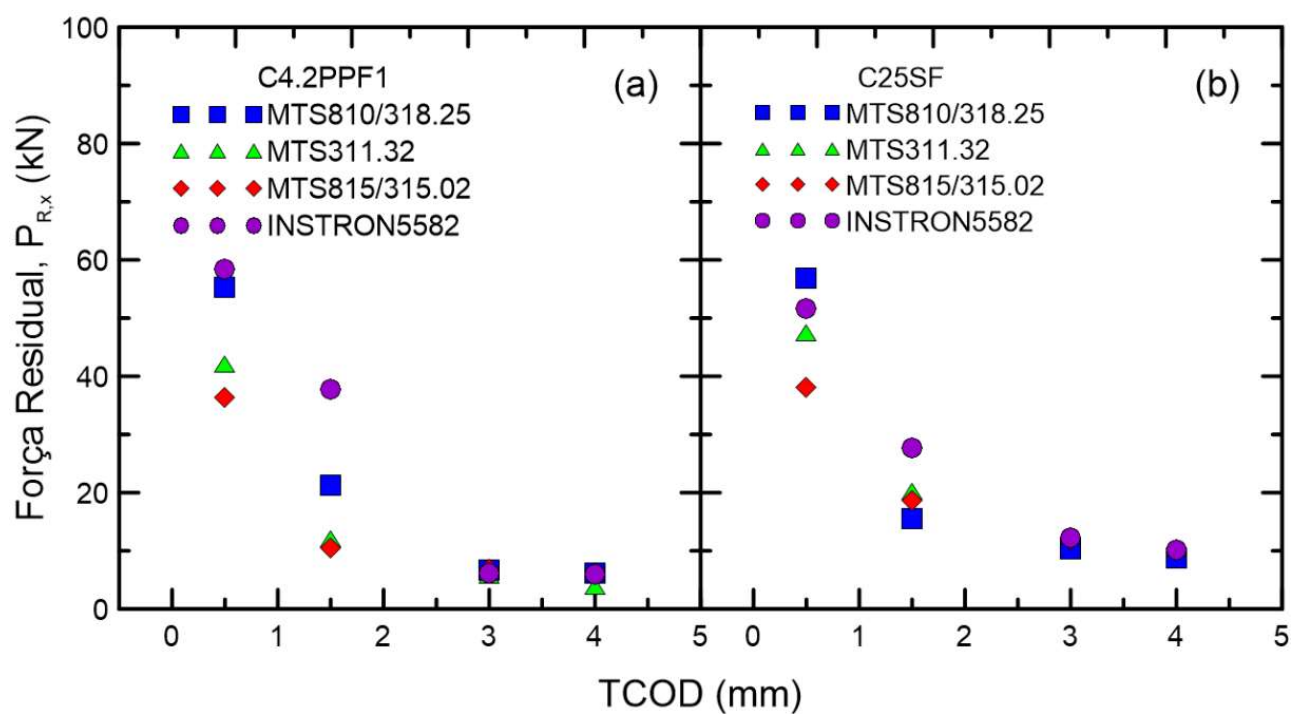

Figura 77 - Variação da força residual para os diferentes tipos de máquinas de ensaio universal estudadas no caso do concreto reforçado com (a) $4,2 \mathrm{~kg} / \mathrm{m}^{3}$ de PPF1 e (b) $25 \mathrm{~kg} / \mathrm{m}^{3}$ de SF 
A norma espanhola UNE 83515 [71] utiliza os parâmetros de resistência pósfissuração para níveis de TCOD a partir de $2 \mathrm{~mm}$. Baseado nos resultados obtidos, obteve-se uma instabilidade máxima de $2,87 \mathrm{~m}$ e $1,97 \mathrm{~mm}$ quando o concreto reforçado com fibras sintéticas e de aço, respectivamente, foi submetido ao ensaio de duplo puncionamento na INSTRON5582, podendo apresentar resultados pouco confiáveis principalmente em termos de força residual. Em termos de tenacidade, os valores podem mudar significativamente dependendo da variação rigidez da máquina. Dessa maneira, pode ser que seja recomendável especificar uma faixa de rigidezes para a realização dos ensaios de duplo puncionamento, visando uma menor variabilidade nos resultados.

Tabela 27 - Resultados médios de força residual $\left(\mathrm{P}_{\mathrm{R}, \mathrm{x}}\right)$ para diferentes níveis de TCOD obtidos a partir do ensaio de duplo puncionamento realizado em diferentes máquinas de ensaio universal para o concreto reforçado com 4,2 kg/m³ de PPF1 e $25 \mathrm{~kg} / \mathrm{m}^{3}$ de SF. Desvio padrão entre

parênteses

\begin{tabular}{|c|c|c|c|c|c|c|c|}
\hline Composição & $\begin{array}{c}\text { Máquina de } \\
\text { Ensaios Universal }\end{array}$ & Controle & $\begin{array}{c}\mathrm{P}_{1} \\
(\mathrm{kN})\end{array}$ & $\begin{array}{l}\mathrm{P}_{\mathrm{R}, 0.5} \\
(\mathrm{kN})\end{array}$ & $\begin{array}{l}\mathrm{PR}_{\mathrm{R}, 1.5} \\
(\mathrm{kN})\end{array}$ & $\begin{array}{l}\mathrm{PR}, 3.0_{\mathrm{R}} \\
(\mathrm{kN})\end{array}$ & $\begin{array}{l}\mathrm{PR}_{\mathrm{R}, 4.0} \\
(\mathrm{kN})\end{array}$ \\
\hline \multirow{8}{*}{ C4.2PPF1 } & \multirow{2}{*}{ MTS810/318.25 } & \multirow{2}{*}{ Atuador } & 70,66 & 55,33 & 21,30 & 6,70 & 6,20 \\
\hline & & & $(2,99)$ & $(4,28)$ & $(7,10)$ & $(0,97)$ & $(0,79)$ \\
\hline & \multirow{2}{*}{ MTS311.32 } & \multirow{2}{*}{ Atuador } & 61,09 & 42,17 & 12,01 & 5,72 & 3,89 \\
\hline & & & $(0,38)$ & $(3,69)$ & $(3,87)$ & $(0,71)$ & $(0,77)$ \\
\hline & \multirow{2}{*}{ MTS815/315.02 } & \multirow{2}{*}{ Atuador } & 64,77 & 36,39 & 10,55 & 6,77 & 6,02 \\
\hline & & & $(7,45)$ & $(8,98)$ & $(4,38)$ & $(3,44)$ & $(2,96)$ \\
\hline & \multirow{2}{*}{ INSTRON5500R } & \multirow{2}{*}{ Atuador } & 67,90 & 58,43 & 37,73 & 6,15 & 5,93 \\
\hline & & & $(1,90)$ & $(1,83)$ & $(2,00)$ & $(0,80)$ & $(1,08)$ \\
\hline \multirow{8}{*}{$\mathrm{C} 25 \mathrm{SF}$} & \multirow{2}{*}{ MTS810/318.25 } & \multirow{2}{*}{ Atuador } & 78,03 & 56,87 & 15,54 & 10,32 & 8,71 \\
\hline & & & $(4,72)$ & $(5,87)$ & $(6,41)$ & $(3,49)$ & $(2,80)$ \\
\hline & \multirow{2}{*}{ MTS311.32 } & \multirow{2}{*}{ Atuador } & 69,95 & 47,48 & 20,24 & 12,62 & 10,48 \\
\hline & & & $(1,33)$ & $(0,27)$ & $(1,84)$ & $(2,60)$ & $(3,20)$ \\
\hline & \multirow{2}{*}{ MTS815/315.02 } & \multirow{2}{*}{ Atuador } & 68,20 & 38,16 & 18,67 & 11,83 & 10,18 \\
\hline & & & $(4,02)$ & $(6,10)$ & $(4,37)$ & $(4,19)$ & $(3,65)$ \\
\hline & \multirow{2}{*}{ INSTRON5500R } & \multirow{2}{*}{ Atuador } & 61,66 & 51,66 & 27,75 & 12,29 & 10,12 \\
\hline & & & $(8,54)$ & $(8,74)$ & $(8,05)$ & $(0,96)$ & $(0,73)$ \\
\hline
\end{tabular}


6.5.2.

Influência da rigidez da máquina de testes universais na correlação entre os ensaios de duplo puncionamento e flexão em três pontos para o concreto reforçado com fibras

\subsubsection{1.}

\section{Equivalência entre os ensaios de duplo puncionamento e flexão em três} pontos

A fim de obter valores comparáveis entre os ensaios de flexão e duplo puncionamento, é necessário estabelecer uma equivalência entre seus resultados a partir dos níveis de abertura de fissura. Para esse fim, foi assumido que, para estágio mais avançados de abertura de fissura, as faces fissuras estão completamente separadas e o prisma está somente unido pelo ponto superior do plano de fratura como mostrado na Figura 78. O trabalho de Carmona et al. [85] foi utilizado como base para correlações efetuadas nesse trabalho.

Considerando que o ensaio de flexão mede a abertura de fissura CMOD abaixo do entalhe, a abertura de fissuras real $(2 w)$ é ligeiramente menor já que ela ocorre na ponta superior do entalhe. Dessa maneira, a abertura de fissura média $(w)$ pode ser calculada no meio da altura do plano de fratura, como mostrado na Figura 78. Essa relação está expressa na Equação 9.

$$
w=\frac{h_{s p}}{2 h} C M O D
$$

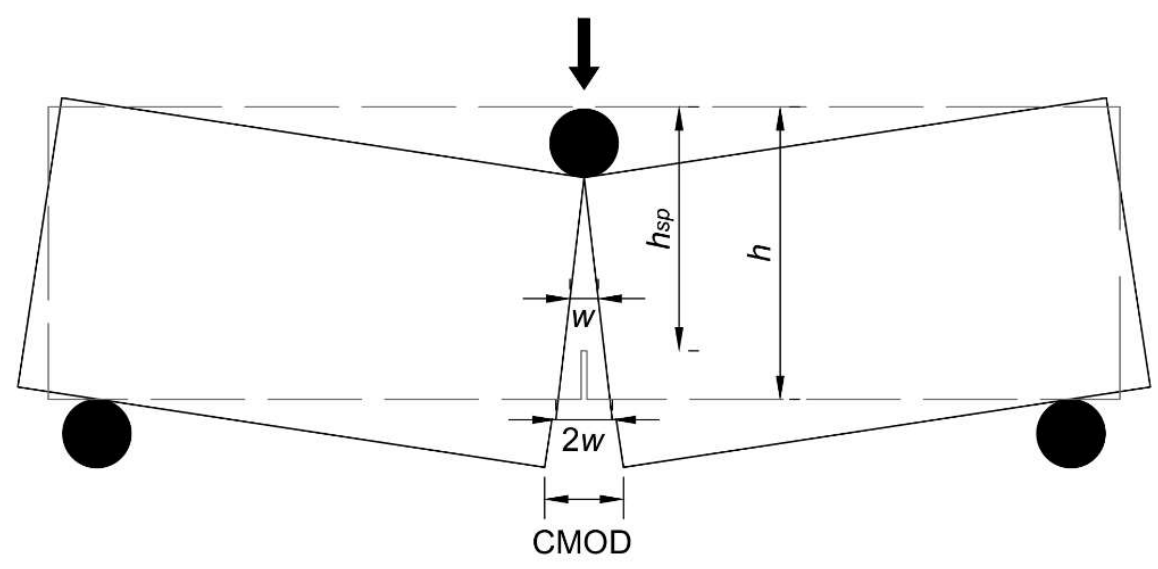

Figura 78 - Desenho esquemático da falha do prima submetido a um ensaio de flexão em três pontos e de sua abertura de fissura 
No caso do ensaio de duplo puncionamento, a falha da amostra produz fraturas radiais e seu valor é medido a partir do aumento do perímetro (TCOD) que é equivalente à soma de todas as fissuras radiais pela corrente. Considerando três fissuras radiais separadas por $120^{\circ}$, a abertura de fissuras média é obtida na Equação 10. O modo de fissuração do ensaio de duplo puncionamento está ilustrado na Figura 79.

$$
w=\frac{T C O D}{3}
$$

Correlacionando as Equações 9 e 10 e considerando $150 \mathrm{~mm}$ e $125 \mathrm{~mm}$ para as alturas $h$ e $h_{s p}$, respectivamente, é possível obter a equivalência indicada na Equação 11.

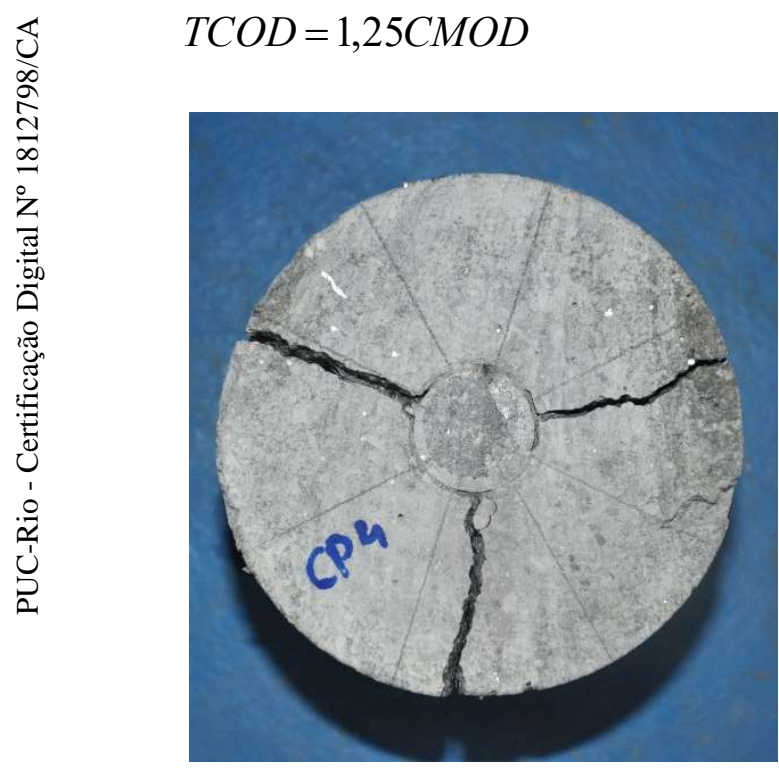

(a)

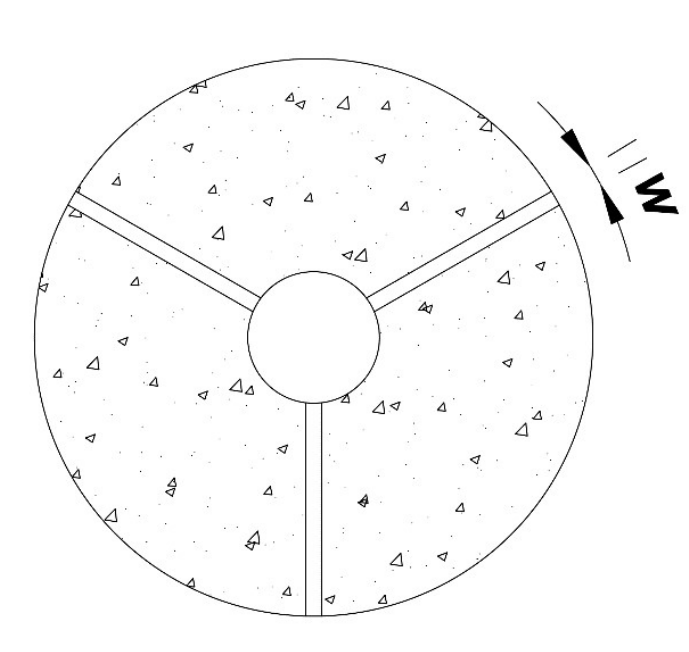

(b)

Figura 79 - Modo de fissuração do ensaio de duplo puncionamento: (a) fotografia e (b) desenho esquemático

Essa equivalência entre $C M O D$ e $T C O D$ permite comparar os valores entre as resistências residuais e tenacidade para os ensaios de flexão em três pontos e duplo puncionamento. As equivalências apresentadas na Tabela 28 foram obtidas através da Equação 11 e foram aplicadas para as correlações desse trabalho. 
Tabela 28 - Equivalências entre os valores de $C M O D, T C O D$ e abertura de fissuras média (w)

\begin{tabular}{lccccccc}
\hline$C M O D(\mathrm{~mm})$ & 0,5 & 1,0 & 1,5 & 2,0 & 2,5 & 3,0 & 3,5 \\
\hline TCOD $(\mathrm{mm})$ & 0,625 & 1,250 & 1,875 & 2,500 & 3,125 & 3,750 & 4,375 \\
$w(\mathrm{~mm})$ & 0,208 & 0,417 & 0,625 & 0,833 & 1,042 & 1,250 & 1,458 \\
\hline
\end{tabular}

6.5.2.2.

\section{Correlação para tenacidade entre os ensaios de duplo puncionamento (EBCN) e flexão em três pontos ( $\left.\mathrm{T}_{\mathrm{EN}}\right)$}

As Tabelas 29 e 30 apresentam os valores de tenacidade obtidos dos ensaios de duplo puncionamento $\left(\mathrm{E}_{\mathrm{BCN}}\right)$ e flexão em três pontos de acordo com a norma $\mathrm{EN}$ $14651[54]\left(\mathrm{T}_{\mathrm{EN}}\right)$ correspondentes à mesma abertura de fissura média. A Figura 80 mostra a correlação entre os ensaios a partir dos valores das duas tabelas.

A partir dos gráficos apresentados na Figura 80, é possível estimar a tenacidade $\mathrm{T}_{\mathrm{EN}}$ através da expressão mostrada na Equação 12.

$$
T_{E N}\left(E_{B C N}(T C O D)\right)=a * e^{\left[b^{*} E_{B C N}(T C O D)\right]}
$$

Onde $a$ e $b$ são dois parâmetros experimentais que dependem das características do concreto reforçado com fibras, da rigidez das máquinas estudadas e do tipo de controle aplicado. A Tabela 31 mostra os valores de $a$ e $b$ obtidos da regressão não linear de cada caso estudado.

Tabela 29 - Resultados de tenacidade obtidos a partir do ensaio de flexão em três pontos. Desvio

$$
\text { padrão entre parênteses }
$$

\begin{tabular}{cccccccc}
\hline Composição & $\begin{array}{c}\mathrm{T}_{0.5} \\
(\mathrm{~J})\end{array}$ & $\begin{array}{c}\mathrm{T}_{1.0} \\
(\mathrm{~J})\end{array}$ & $\begin{array}{c}\mathrm{T}_{1.5} \\
(\mathrm{~J})\end{array}$ & $\begin{array}{c}\mathrm{T}_{2.0} \\
(\mathrm{~J})\end{array}$ & $\begin{array}{c}\mathrm{T}_{2.5} \\
(\mathrm{~J})\end{array}$ & $\begin{array}{c}\mathrm{T}_{3.0} \\
(\mathrm{~J})\end{array}$ & $\begin{array}{c}\mathrm{T}_{3.5} \\
(\mathrm{~J})\end{array}$ \\
\hline \multirow{2}{*}{ C4.2PPF1 } & 2,93 & 4,46 & 6,03 & 7,74 & 9,56 & 11,49 & 13,46 \\
& $(0,09)$ & $(0,24)$ & $(0,46)$ & $(0,70)$ & $(0,95)$ & $(1,23)$ & $(1,50)$ \\
C25SF & 4,73 & 8,99 & 13,78 & 18,42 & 23,03 & 27,50 & 31,99 \\
& $(0,54)$ & $(0,94)$ & $(1,04)$ & $(1,46)$ & $(1,53)$ & $(1,78)$ & $(1,92)$ \\
\hline
\end{tabular}


Tabela 30 - Resultados de tenacidade obtidos a partir do ensaio de duplo puncionamento. Desvio padrão entre parênteses

\begin{tabular}{|c|c|c|c|c|c|c|c|c|c|}
\hline Composição & Máquinas & Controle & $\begin{array}{c}E_{0.625} \\
(\mathrm{~J}) \\
\end{array}$ & $\begin{array}{c}E_{1.25} \\
(J) \\
\end{array}$ & $\begin{array}{c}E_{1.875} \\
(\mathrm{~J}) \\
\end{array}$ & $\begin{array}{c}\mathrm{E}_{2.5} \\
(\mathrm{~J}) \\
\end{array}$ & $\begin{array}{c}E_{3.125} \\
(\mathrm{~J}) \\
\end{array}$ & $\begin{array}{c}E_{3.75} \\
(\mathrm{~J}) \\
\end{array}$ & $\begin{array}{c}E_{4.375} \\
(\mathrm{~J}) \\
\end{array}$ \\
\hline C4.2PPF1 & $\begin{array}{c}\text { MTS } \\
810 / 318.25\end{array}$ & Atuador & $\begin{array}{l}22,67 \\
(0,58)\end{array}$ & $\begin{array}{l}47,33 \\
(0,58)\end{array}$ & $\begin{array}{l}67,69 \\
(3,48)\end{array}$ & $\begin{array}{l}79,27 \\
(8,63)\end{array}$ & $\begin{array}{l}83,58 \\
(8,76)\end{array}$ & $\begin{array}{l}87,63 \\
(9,16)\end{array}$ & $\begin{array}{l}91,47 \\
(9,50)\end{array}$ \\
\hline \multirow{9}{*}{$\mathrm{C} 25 \mathrm{SF}$} & $\begin{array}{c}\text { MTS } \\
311.32\end{array}$ & Atuador & $\begin{array}{l}24,33 \\
(2,52)\end{array}$ & $\begin{array}{l}46,94 \\
(6,98)\end{array}$ & $\begin{array}{l}53,77 \\
(8,91)\end{array}$ & $\begin{array}{l}58,88 \\
(9,79)\end{array}$ & $\begin{array}{l}62,70 \\
(9,89)\end{array}$ & $\begin{array}{l}65,59 \\
(9,83)\end{array}$ & $\begin{array}{l}67,97 \\
(9,62)\end{array}$ \\
\hline & $\begin{array}{c}\text { MTS } \\
815 / 315.02\end{array}$ & Atuador & $\begin{array}{l}26,56 \\
(2,69)\end{array}$ & $\begin{array}{l}41,32 \\
(3,85)\end{array}$ & $\begin{array}{l}47,77 \\
(1,74)\end{array}$ & $\begin{array}{l}52,66 \\
(1,95)\end{array}$ & $\begin{array}{l}56,99 \\
(3,72)\end{array}$ & $\begin{array}{l}61,04 \\
(5,68)\end{array}$ & $\begin{array}{l}64,26 \\
(7,90)\end{array}$ \\
\hline & $\begin{array}{c}\text { INSTRON } \\
5582\end{array}$ & Atuador & $\begin{array}{l}33,67 \\
(0,76)\end{array}$ & $\begin{array}{l}59,67 \\
(2,89)\end{array}$ & $\begin{array}{l}76,34 \\
(4,31)\end{array}$ & $\begin{array}{l}88,09 \\
(4,07)\end{array}$ & $\begin{array}{l}95,58 \\
(5,58)\end{array}$ & $\begin{array}{l}102,51 \\
(6,36)\end{array}$ & $\begin{array}{l}108,78 \\
(7,04)\end{array}$ \\
\hline & $\begin{array}{c}\text { MTS } \\
810 / 318.25\end{array}$ & $\begin{array}{c}\text { Corrente } \\
\text { Extenso- } \\
\text { métrica }\end{array}$ & $\begin{array}{l}19,40 \\
(1,40)\end{array}$ & $\begin{array}{l}31,18 \\
(3,40)\end{array}$ & $\begin{array}{l}37,41 \\
(5,37)\end{array}$ & $\begin{array}{l}41,80 \\
(7,20)\end{array}$ & $\begin{array}{l}45,26 \\
(8,95)\end{array}$ & $\begin{array}{c}48,14 \\
(10,50)\end{array}$ & $\begin{array}{c}50,07 \\
(11,71)\end{array}$ \\
\hline & $\begin{array}{c}\text { MTS } \\
810 / 318.25\end{array}$ & Atuador & $\begin{array}{l}28,83 \\
(4,25)\end{array}$ & $\begin{array}{l}57,79 \\
(8,56)\end{array}$ & $\begin{array}{c}71,19 \\
(10,09)\end{array}$ & $\begin{array}{c}79,31 \\
(12,61)\end{array}$ & $\begin{array}{c}86,03 \\
(14,84)\end{array}$ & $\begin{array}{c}92,11 \\
(16,80)\end{array}$ & $\begin{array}{c}97,45 \\
(18,43)\end{array}$ \\
\hline & $\begin{array}{c}\text { MTS } \\
311.32\end{array}$ & Atuador & $\begin{array}{l}34,58 \\
(1,44)\end{array}$ & $\begin{array}{l}53,35 \\
(1,85)\end{array}$ & $\begin{array}{l}65,77 \\
(2,24)\end{array}$ & $\begin{array}{l}75,73 \\
(3,19)\end{array}$ & $\begin{array}{l}83,98 \\
(4,40)\end{array}$ & $\begin{array}{l}91,17 \\
(6,18)\end{array}$ & $\begin{array}{l}97,67 \\
(8,19)\end{array}$ \\
\hline & $\begin{array}{c}\text { MTS } \\
815 / 315.02\end{array}$ & Atuador & $\begin{array}{l}30,87 \\
(2,72)\end{array}$ & $\begin{array}{l}49,10 \\
(5,26)\end{array}$ & $\begin{array}{l}60,49 \\
(7,66)\end{array}$ & $\begin{array}{c}69,27 \\
(10,33)\end{array}$ & $\begin{array}{c}76,87 \\
(12,90)\end{array}$ & $\begin{array}{c}83,86 \\
(15,29)\end{array}$ & $\begin{array}{c}90,60 \\
(17,46)\end{array}$ \\
\hline & $\begin{array}{c}\text { INSTRON } \\
5582\end{array}$ & Atuador & $\begin{array}{l}33,67 \\
(4,51)\end{array}$ & $\begin{array}{c}59,67 \\
(10,02)\end{array}$ & $\begin{array}{c}76,34 \\
(15,02)\end{array}$ & $\begin{array}{c}88,09 \\
(19,48)\end{array}$ & $(18,95)$ & $(19,37)$ & $\begin{array}{l}108,78 \\
(19,72)\end{array}$ \\
\hline & $\begin{array}{c}\text { MTS } \\
810 / 318.25\end{array}$ & $\begin{array}{c}\text { Corrente } \\
\text { Extenso- } \\
\text { métrica }\end{array}$ & $\begin{array}{l}24,28 \\
(2,09)\end{array}$ & $\begin{array}{l}40,46 \\
(4,08)\end{array}$ & $\begin{array}{l}51,20 \\
(6,14)\end{array}$ & $\begin{array}{l}59,12 \\
(8,53)\end{array}$ & $\begin{array}{c}65,49 \\
(11,02)\end{array}$ & 71,04 & 74,33 \\
\hline
\end{tabular}
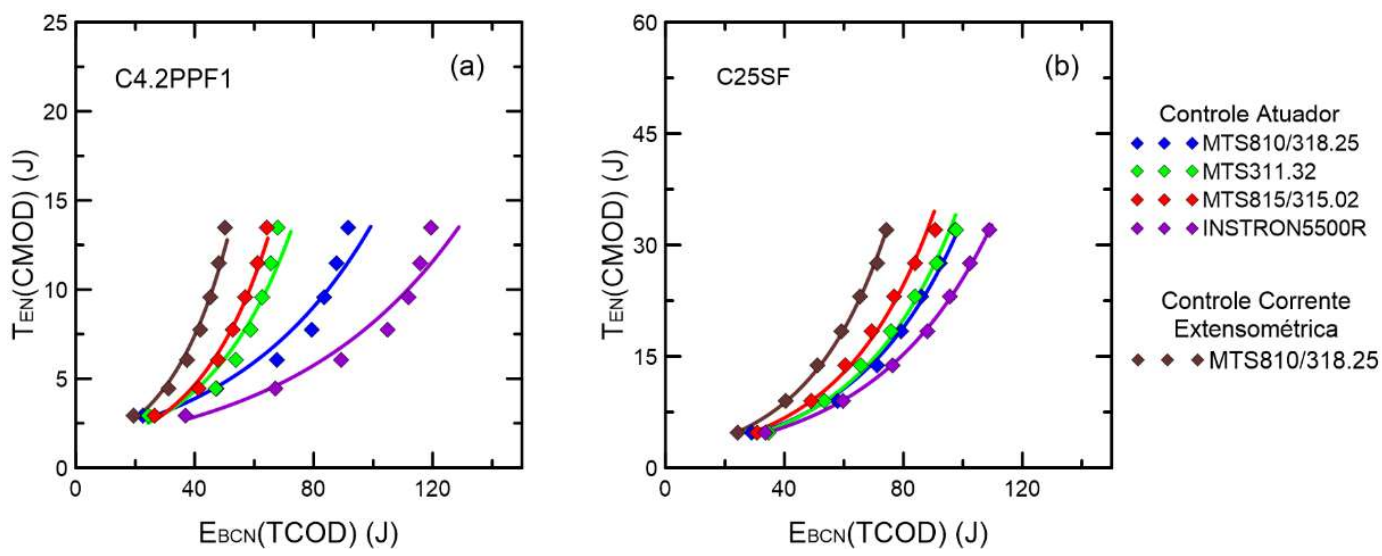

Figura 80 - Correlação entre as tenacidade obtidas a partir dos ensaios de flexão em três pontos

$$
\left(\mathrm{T}_{\mathrm{EN}}\right) \text { e de duplo puncionamento }\left(\mathrm{E}_{\mathrm{BCN}}\right) \text { : (a) C4.2PPF1 e (b) C25SF }
$$

Diversos trabalhos já estudaram o efeito da variação do tipo do concreto, do tipo e da fração volumétrica das fibras nos parâmetros que correlacionam os dois ensaios [85-88], mas pouco ainda foi discutido em relação à influência das 
mudanças na rigidez das máquinas. Dessa maneira, como previsto pelas curvas apresentadas na Figura 80, os valores de $a$ e $b$ mudam significativamente com a variação da rigidez das máquinas. Os valores do parâmetro $a$ oscilam com o aumento da rigidez das máquinas e com a mudança no tipo de controle. Não apresentam, portanto, uma tendência bem definida. Já o parâmetro $b$, por sua vez, apresenta uma tendência de aumento com o aumento da rigidez. Além disso, o parâmetro $b$ atinge seu maior valor com o controle fechado pela corrente extensométrica. Isso deve estar associado com a variação das tenacidades obtidas dos ensaios de Barcelona, que previu uma diminuição da capacidade de energia absorvida com o aumento da rigidez da máquina e com o controle pela corrente extensométrica.

Tabela 31 - Parâmetros de correlação entre $\mathrm{T}_{\mathrm{EN}}$ e $\mathrm{E}_{\mathrm{BCN}}$ para o concreto reforçado com fibras nas diferentes máquinas de ensaio e metodologias de controle

\begin{tabular}{ccccccc}
\hline Composição & $\begin{array}{c}\text { Máquina de } \\
\text { Ensaios Universal }\end{array}$ & Controle & $K(\mathrm{~N} / \mathrm{m})$ & $a$ & $b$ & $r^{2}$ \\
\hline C4.2PPF1 & MTS810/318.25 & Atuador & $4,3 \times 10^{8}$ & 1,671 & 0,021 & 0,955 \\
& MTS311.32 & Atuador & $21 \times 10^{8}$ & 1,078 & 0,035 & 0,926 \\
& MTS815/315.02 & Atuador & $90 \times 10^{8}$ & 0,890 & 0,041 & 0,985 \\
& INSTRON5500R & Atuador & $2,5 \times 10^{8}$ & 1,418 & 0,018 & 0,960 \\
& MTS810/318.25 & Corrente & $4,3 \times 10^{8}$ & 1,019 & 0,049 & 0,982 \\
C25SF & MTS810/318.25 & Atuador & $4,3 \times 10^{8}$ & 1,92 & 0,029 & 0,991 \\
& MTS311.32 & Atuador & $21 \times 10^{8}$ & 1,754 & 0,030 & 0,995 \\
& MTS815/315.02 & Atuador & $90 \times 10^{8}$ & 1,831 & 0,033 & 0,994 \\
& INSTRON5500R & Atuador & $2,5 \times 10^{8}$ & 1,972 & 0,026 & 1,000 \\
& MTS810/318.25 & Corrente & $4,3 \times 10^{8}$ & 1,930 & 0,038 & 0,999 \\
\hline
\end{tabular}

Com os valores de $\mathrm{E}_{\mathrm{BCN}}(T C O D)$ mostrados na Tabela 30 e usando a Equação 12, os valores de $\mathrm{T}_{\mathrm{EN}}\left(\mathrm{E}_{\mathrm{BCN}}(T C O D)\right)$ foram estimados e apresentados na Tabela 32 . Além disso o erro para diferentes níveis de TCOD podem ser analisados na Figura 81. Baseado nesses resultados, o erro entre os valores estimados com as correlações e a tenacidade $\mathrm{T}_{\mathrm{EN}}$ dos ensaios de flexão é consideravelmente maior para os ensaios realizados com as fibras sintéticas. Esse maior erro está associado com uma maior variação da tenacidade com o uso desse tipo de fibra em diferentes máquinas e com 
uma maior instabilidade pós-pico que acarreta em uma perda de leitura nos níveis iniciais de expansão radial. Enquanto C4.2PPF1 apresenta um erro máximo próximo dos $30 \%$, C25SF figura abaixo de $15 \%$.

Vale notar que o aumento da rigidez não necessariamente resultou em menores erros na análise das correlações para tenacidade para as duas fibras estudadas. Especificamente para $\mathrm{C} 4.2 \mathrm{PPF} 1$, apesar da máquina mais rígida MTS815/315.02 apresentar, em geral, correlações mais próximas dos valores obtidos na flexão, o erro nas outras máquinas se mostrou semelhante. O mesmo vale para a aplicação do controle pela corrente extensométrica, que apresentou erros próximos das máquinas mais rígidas.
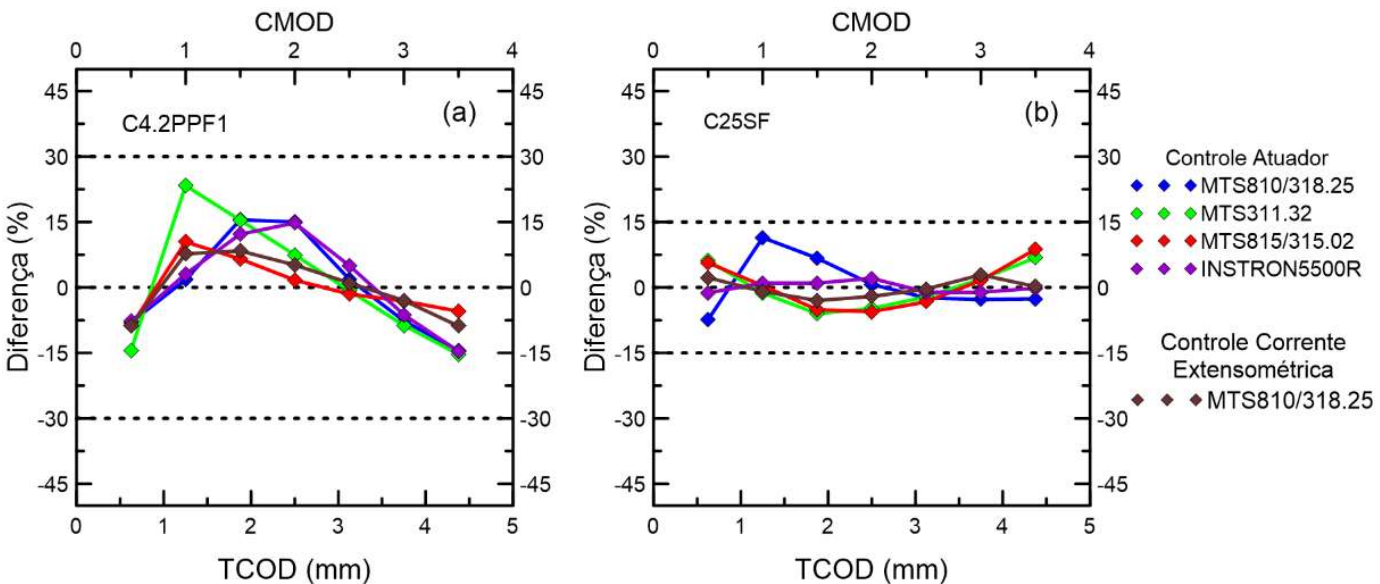

Figura 81 - Variação do erro entre a tenacidade obtida no ensaio de flexão em três pontos $\left(\mathrm{T}_{\mathrm{EN}}\right)$ e a partir das correlações com o ensaio de duplo puncionamento $\left(\mathrm{T}_{\mathrm{EN}}\left(\mathrm{E}_{\mathrm{BCN}}(T C O D)\right)\right)$ para as diferentes máquinas estudadas. Resultados obtidos para a adição de 4,2 kg/m³ de PPF1 e $25 \mathrm{~kg} / \mathrm{m}^{3}$ de SF 
Tabela 32 - Valores de tenacidade estimados a partir das correlações entre os ensaios de flexão em três pontos e duplo puncionamento em diferentes níveis de TCOD. Resultados obtidos para a adição de 4,2 kg/m³ de PPF1 e $25 \mathrm{~kg} / \mathrm{m}^{3}$ de SF

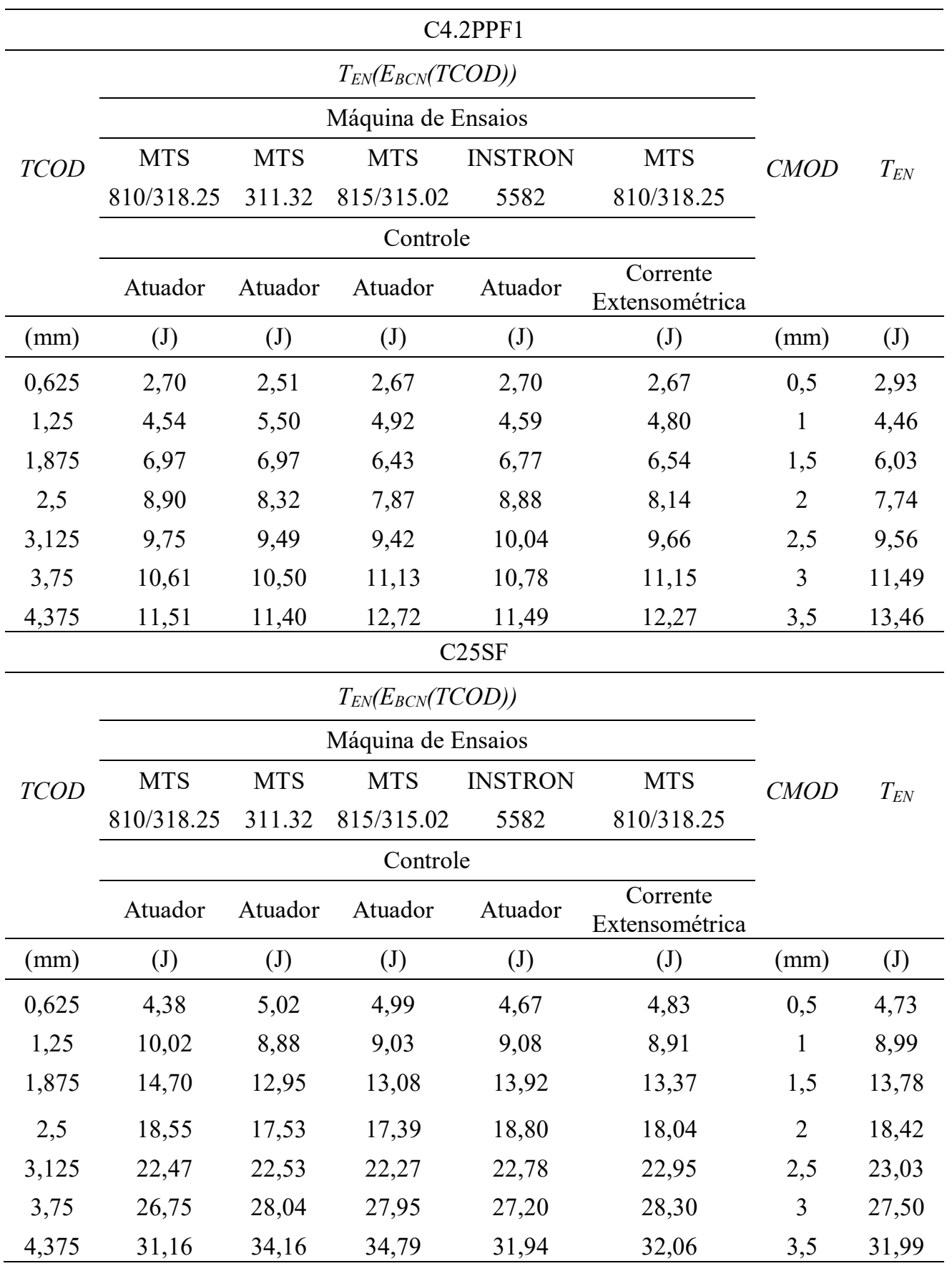


6.5.2.3.

Correlação para tensões residuais entre os ensaios de duplo puncionamento $\left(f_{c t, R x}\right)$ e flexão em três pontos $\left(F_{R, j}\right)$

As Tabelas 33 e 34 apresentam os valores de tensão residual obtidos dos ensaios de duplo puncionamento $\left(f_{c t, R x}\right)$ e flexão em três pontos $\left(F_{R, j}\right)$ de acordo com a norma EN 14651 [54] correspondentes à mesma abertura de fissura média.

Nessa seção, procedimento semelhante foi aplicado para a avaliar a influência da rigidez das máquinas de ensaio na correlação para as tensões residuais entre os ensaios de duplo puncionamento $\left(\mathrm{f}_{\mathrm{ct}, \mathrm{Rx}}\right)$ e flexão em três pontos $\left(\mathrm{F}_{\mathrm{R}, \mathrm{j}}\right)$. Em contraste ao observado na relação entre $\mathrm{E}_{\mathrm{BCN}}(T C O D)$ e $\mathrm{T}_{\mathrm{EN}}(C M O D)$, não há uma única tendência possível para correlacionar $\mathrm{f}_{\mathrm{ct}, \mathrm{Rx}}$ e $\mathrm{F}_{\mathrm{R}, \mathrm{j}}$. Assim como proposto por Carmona et al. [85], foi possível estabelecer uma relação a partir da razão $F_{R, j} / f_{c t, R x}$ como mostrado na Equação 13. As tendências obtidas com a Equação 13 podem ser estudadas na Figura 82.

$$
\frac{F_{R, j}\left(f_{c t, R x}(T C O D)\right)}{f_{c t, R x}(T C O D)}=c T_{C O D}^{d}
$$

Onde $c$ e $d$ também são parâmetros experimentais que dependem do tipo de concreto e da quantidade de fibras do material. Os dois parâmetros obtidos através de regressões não lineares para cada máquina de ensaios universal estudada e tipo de fibra podem ser analisados na Tabela 35. Assim como nas correlações para tenacidade, os parâmetros $c$ e $d$ variam em função da rigidez das máquinas. Enquanto o primeiro apresenta uma tendência de aumento para maiores valores de $K$, o segundo já resulta em uma queda. As tendências são semelhantes para os dois tipos de fibras estudadas.

Tabela 33 - Resultados de tensão residual obtidos a partir do ensaio de flexão em três pontos.

Desvio padrão entre parênteses

\begin{tabular}{cccccccc}
\hline \multirow{2}{*}{ Composição } & $\begin{array}{c}\mathrm{F}_{\mathrm{R}, 0.5} \\
(\mathrm{MPa})\end{array}$ & $\begin{array}{c}\mathrm{F}_{\mathrm{R}, 1.0} \\
(\mathrm{MPa})\end{array}$ & $\begin{array}{c}\mathrm{F}_{\mathrm{R}, 1.5} \\
(\mathrm{MPa})\end{array}$ & $\begin{array}{c}\mathrm{F}_{\mathrm{R}, 2.0} \\
(\mathrm{MPa})\end{array}$ & $\begin{array}{c}\mathrm{F}_{\mathrm{R}, 2.5} \\
(\mathrm{MPa})\end{array}$ & $\begin{array}{c}\mathrm{F}_{\mathrm{R}, 3.0} \\
(\mathrm{MPa})\end{array}$ & $\begin{array}{c}\mathrm{F}_{\mathrm{R}, 3.5} \\
(\mathrm{MPa})\end{array}$ \\
\hline \multirow{2}{*}{ C4.2PPF1 } & 1,04 & 0,96 & 1,04 & 1,11 & 1,18 & 1,23 & 1,26 \\
& $(0,07)$ & $(0,11)$ & $(0,13)$ & $(0,14)$ & $(0,14)$ & $(0,15)$ & $(0,16)$ \\
C25SF & 2,69 & 2,93 & 2,98 & 2,95 & 2,92 & 2,90 & 2,74 \\
& $(0,25)$ & $(0,20)$ & $(0,20)$ & $(0,14)$ & $(0,16)$ & $(0,25)$ & $(0,27)$ \\
\hline
\end{tabular}


Tabela 34 - Resultados de tensão residual obtidos a partir do ensaio de duplo puncionamento.

Desvio padrão entre parênteses

\begin{tabular}{|c|c|c|c|c|c|c|c|c|c|}
\hline Composição & Máquinas & Controle & $\begin{array}{l}\mathrm{fct}_{0,} .625 \\
\text { (MPa) }\end{array}$ & $\begin{array}{l}\mathrm{f}_{\mathrm{ct}, 1.25} \\
\text { (MPa) }\end{array}$ & $\begin{array}{l}\mathrm{f}_{\mathrm{ct}, 1.875} \\
\text { (MPa) }\end{array}$ & $\begin{array}{l}\mathrm{fct}_{\mathrm{ct}, 2.5} \\
\text { (MPa) }\end{array}$ & $\begin{array}{l}\mathrm{fct}_{\mathrm{ct}} .125 \\
\text { (MPa) }\end{array}$ & $\begin{array}{l}\mathrm{f}_{\mathrm{ct},}, 3.75 \\
\text { (MPa) }\end{array}$ & $\begin{array}{l}f_{c t,} 4.375 \\
\text { (MPa) }\end{array}$ \\
\hline \multirow{2}{*}{ C4.2PPF1 } & MTS & \multirow{2}{*}{ Atuador } & 2,87 & 1,65 & 0,66 & 0,41 & 0,37 & 0,36 & 0,34 \\
\hline & $810 / 318.25$ & & $(0,20)$ & $(0,35)$ & $(0,10)$ & $(0,12)$ & $(0,06)$ & $(0,05)$ & $(0,04)$ \\
\hline \multirow{18}{*}{$\mathrm{C} 25 \mathrm{SF}$} & MTS & \multirow{2}{*}{ Atuador } & 2,07 & 0,81 & 0,54 & 0,39 & 0,30 & 0,24 & 0,20 \\
\hline & 311.32 & & $(0,33)$ & $(0,36)$ & $(0,13)$ & $(0,04)$ & $(0,04)$ & $(0,05)$ & $(0,04)$ \\
\hline & MTS & \multirow{2}{*}{ Atuador } & 1,67 & 0,75 & 0,49 & 0,41 & 0,38 & 0,36 & 0,32 \\
\hline & $815 / 315.02$ & & $(0,36)$ & $(0,27)$ & $(0,24)$ & $(0,20)$ & $(0,20)$ & $(0,19)$ & $(0,14)$ \\
\hline & INSTRON & \multirow{2}{*}{ Atuador } & 3,19 & 2,46 & 1,74 & 0,98 & 0,34 & 0,35 & 0,31 \\
\hline & 5582 & & $(0,11)$ & $(0,07)$ & $(0,07)$ & $(0,03)$ & $(0,13)$ & $(0,07)$ & $(0,06)$ \\
\hline & MTS & \multirow{2}{*}{$\begin{array}{c}\text { Corrente } \\
\text { Extenso- } \\
\text { métrica }\end{array}$} & 1,45 & 0,74 & 0,45 & 0,35 & 0,28 & 0,24 & 0,17 \\
\hline & $810 / 318.25$ & & $(0,21)$ & $(0,24)$ & $(0,20)$ & $(0,18)$ & $(0,16)$ & $(0,13)$ & $(0,06)$ \\
\hline & MTS & \multirow{2}{*}{ Atuador } & 2,67 & 0,97 & 0,80 & 0,67 & 0,58 & 0,52 & 0,45 \\
\hline & $810 / 318.25$ & & $(0,24)$ & $(0,29)$ & $(0,25)$ & $(0,24)$ & $(0,20)$ & $(0,18)$ & $(0,16)$ \\
\hline & MTS & \multirow{2}{*}{ Atuador } & 2,31 & 1,30 & 1,00 & 0,81 & 0,70 & 0,60 & 0,57 \\
\hline & 311.32 & & $(0,14)$ & $(0,09)$ & $(0,12)$ & $(0,14)$ & $(0,15)$ & $(0,18)$ & $(0,19)$ \\
\hline & MTS & \multirow{2}{*}{ Atuador } & 2,01 & 1,28 & 0,87 & 0,74 & 0,66 & 0,60 & 0,54 \\
\hline & $815 / 315.02$ & & $(0,35)$ & $(0,20)$ & $(0,25)$ & $(0,27)$ & $(0,23)$ & $(0,21)$ & $(0,20)$ \\
\hline & INSTRON & \multirow{2}{*}{ Atuador } & 2,75 & 1,93 & 1,17 & 0,78 & 0,67 & 0,59 & 0,55 \\
\hline & 5582 & & $(0,45)$ & $(0,48)$ & $(0,51)$ & $(0,04)$ & $(0,05)$ & $(0,05)$ & $(0,02)$ \\
\hline & MTS & \multirow{2}{*}{$\begin{array}{c}\text { Corrente } \\
\text { Extenso- } \\
\text { métrica }\end{array}$} & 1,92 & 1,16 & 0,81 & 0,65 & 0,49 & 0,49 & 0,40 \\
\hline & $810 / 318.25$ & & $(0,06)$ & $(0,17)$ & $(0,21)$ & $(0,23)$ & $(0,23)$ & $(0,18)$ & $(0,19)$ \\
\hline
\end{tabular}

Com os valores de $\mathrm{f}_{\mathrm{ct}, \mathrm{Rx}}(T C O D)$ mostrados na Tabela 34 e usando a Equação 13, calculou-se pela correlação $\mathrm{F}_{\mathrm{R}, \mathrm{j}}\left(\mathrm{f}_{\mathrm{ct}, \mathrm{Rx}}(T C O D)\right)$ e sua estimativa está apresentada na Tabela 36. Além disso o erro para diferentes níveis de TCOD podem ser analisados na Figura 83. De acordo com os erros apresentados, percebe-se uma variação significativa no erro em diferentes níveis de TCOD. A diferença entre a tensão residual estimada pela correlação e a obtida dos ensaios de flexão são maiores para menores níveis de TCOD. Além disso, menores erros foram alcançados quando o ensaio de duplo puncionamento foi executado nas máquinas de maior rigidez ou quando o controle pela corrente extensométrica foi aplicado. 
Tabela 35 - Parâmetros de correlação entre $f_{c t, R x}$ e $F_{R, j}$ para o concreto reforçado com fibras nas diferentes máquinas de ensaio e metodologias de controle

\begin{tabular}{ccccccc}
\hline Composição & $\begin{array}{c}\text { Máquina de } \\
\text { Ensaios Universal }\end{array}$ & Controle & $K(\mathrm{~N} / \mathrm{m})$ & $c$ & $d$ & $r^{2}$ \\
\hline C4.2PPF1 & MTS810/318.25 & Atuador & $4,3 \times 10^{8}$ & 0,615 & 1,336 & 0,951 \\
& MTS311.32 & Atuador & $21 \times 10^{8}$ & 0,889 & 1,306 & 0,998 \\
& MTS815/315.02 & Atuador & $90 \times 10^{8}$ & 1,040 & 0,952 & 0,986 \\
& INSTRON5500R & Atuador & $2,5 \times 10^{8}$ & 0,405 & 1,481 & 0,856 \\
& MTS810/318.25 & Corrente & $4,3 \times 10^{8}$ & 1,126 & 1,158 & 0,993 \\
C25SF & MTS810/318.25 & Atuador & $4,3 \times 10^{8}$ & 1,91 & 0,87 & 0,931 \\
& MTS311.32 & Atuador & $21 \times 10^{8}$ & 1,786 & 0,738 & 0,984 \\
& MTS815/315.02 & Atuador & $90 \times 10^{8}$ & 1,978 & 0,697 & 0,980 \\
& INSTRON5500R & Atuador & $2,5 \times 10^{8}$ & 1,434 & 0,917 & 0,976 \\
& MTS810/318.25 & Corrente & $4,3 \times 10^{8}$ & 2,115 & 0,824 & 0,992 \\
\hline
\end{tabular}

Ao contrário do que ocorre com a tenacidade, a variação do erro é mais sensível à mudança das máquinas de ensaio para a força residual. É possível perceber que o maior valor de erro foi obtido ao realizar os ensaios na máquina de menor rigidez (INSTRON5582), enquanto a menor diferença foi observada nas máquinas com maior rigidez (MTS311.32 e MTS815/315.02). Isso se deve mais uma vez à maior instabilidade pós-pico que compromete a leitura das tensões residuais logo após a fissuração da matriz. Pelo mesmo motivo, maiores erros foram encontrados no uso das fibras sintéticas.
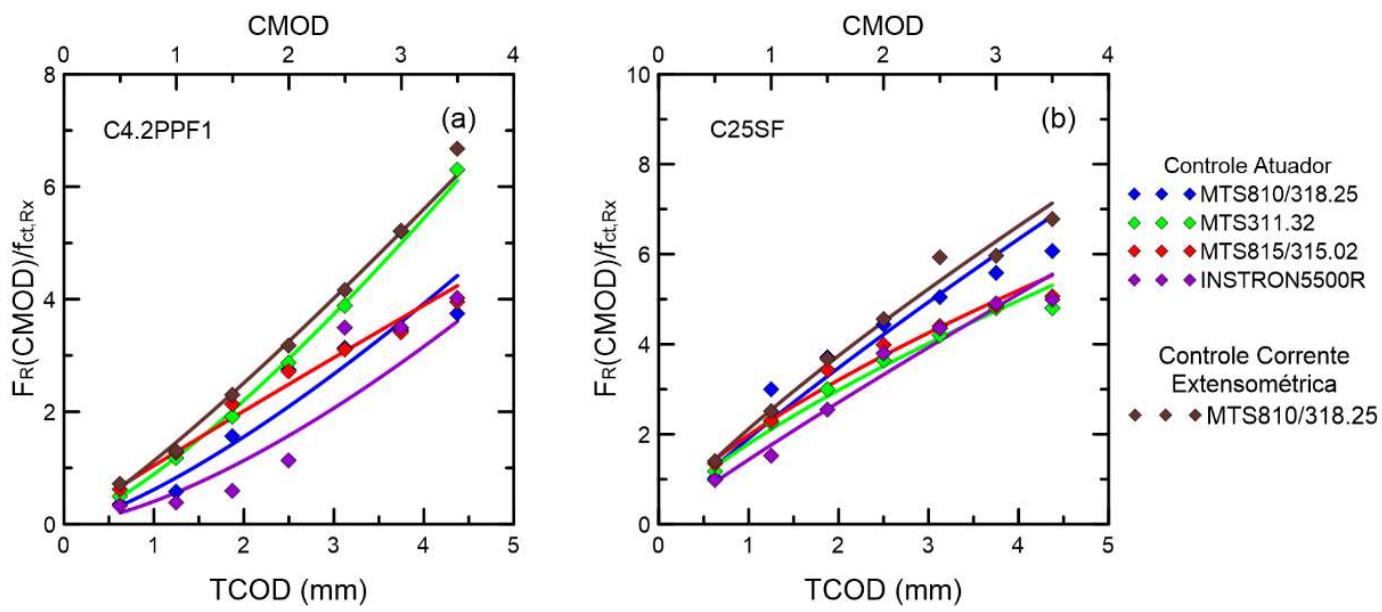

Figura 82 - Correlação para tensões residuais entre os ensaios de duplo puncionamento $\left(f_{c t, R x}\right)$ e flexão em três pontos $\left(\mathrm{F}_{\mathrm{R}, \mathrm{j}}\right)$ : (a) C4.2PPF2 e (b) C25SF 

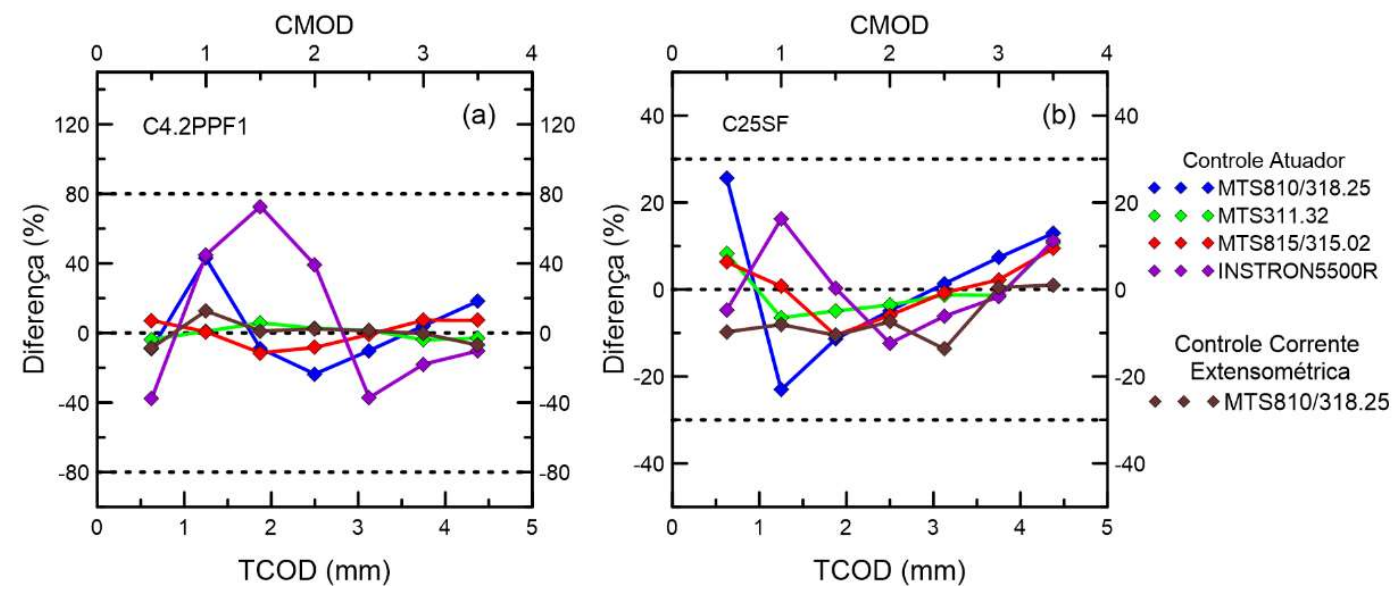

Figura 83 - Variação do erro entre a tensão residual obtida no ensaio de flexão em três pontos $\left(\mathrm{F}_{\mathrm{R}, \mathrm{j}}\right)$

e a partir das correlações com o ensaio de duplo puncionamento $\left(\mathrm{F}_{\mathrm{R}, \mathrm{j}}\left(\mathrm{f}_{\mathrm{ct}, \mathrm{Rx}}(T C O D)\right)\right)$ para as diferentes máquinas estudadas. Resultados obtidos para a adição de (a) 4,2 kg/m³ de PPF1 e (b) 25 $\mathrm{kg} / \mathrm{m}^{3}$ de SF 
Tabela 36 - Valores de tensão residual estimados a partir das correlações entre os ensaios de flexão em três pontos e duplo puncionamento para cada máquina de ensaios estudadas. Resultados obtidos para a adição de $4,2 \mathrm{~kg} / \mathrm{m}^{3}$ de PPF1 e $25 \mathrm{~kg} / \mathrm{m}^{3}$ de $\mathrm{SF}$

\begin{tabular}{|c|c|c|c|c|c|c|c|}
\hline \multicolumn{8}{|c|}{$\mathrm{C} 4.2 \mathrm{PPF} 1$} \\
\hline \multirow{6}{*}{ TCOD } & & & $F_{R, j}\left(f_{c t, R x}(T C\right.$ & $D, K)$ & & \multirow{6}{*}{$C M O D$} & \multirow{6}{*}{$\mathrm{F}_{\mathrm{R}, \mathrm{j}}$} \\
\hline & & & Máquina de I & nsaios & & & \\
\hline & MTS & MTS & MTS & INSTRON & MTS & & \\
\hline & $810 / 318.25$ & 311.32 & $815 / 315.02$ & 5582 & $810 / 318.25$ & & \\
\hline & \multicolumn{5}{|c|}{ Controle } & & \\
\hline & Atuador & Atuador & Atuador & Atuador & $\begin{array}{c}\text { Corrente } \\
\text { Extensométrica }\end{array}$ & & \\
\hline$(\mathrm{mm})$ & $(\mathrm{MPa})$ & $(\mathrm{MPa})$ & $(\mathrm{MPa})$ & $(\mathrm{MPa})$ & $(\mathrm{MPa})$ & $(\mathrm{mm})$ & $(\mathrm{MPa})$ \\
\hline 0,625 & 0,94 & 1,00 & 1,11 & 0,64 & 0,95 & 0,5 & 1,04 \\
\hline 1,25 & 1,37 & 0,97 & 0,96 & 1,39 & 1,08 & 1 & 0,96 \\
\hline 1,875 & 0,95 & 1,10 & 0,92 & 1,79 & 1,05 & 1,5 & 1,04 \\
\hline 2,5 & 0,85 & 1,14 & 1,02 & 1,54 & 1,14 & 2 & 1,11 \\
\hline 3,125 & 1,06 & 1,19 & 1,17 & 0,74 & 1,19 & 2,5 & 1,18 \\
\hline 3,75 & 1,28 & 1,18 & 1,32 & 1,01 & 1,22 & 3 & 1,23 \\
\hline 4,375 & 1,49 & 1,22 & 1,35 & 1,13 & 1,17 & 3,5 & 1,26 \\
\hline
\end{tabular}

\begin{tabular}{|c|c|c|c|c|c|c|c|}
\hline \multirow{6}{*}{ TCOD } & \multicolumn{5}{|c|}{$F_{R, j}\left(f_{c t, R x}(T C O D, K)\right)$} & \multirow{6}{*}{$C M O D$} & \multirow{6}{*}{$F_{R, j}$} \\
\hline & \multicolumn{5}{|c|}{ Máquina de Ensaios } & & \\
\hline & MTS & MTS & MTS & INSTRON & MTS & & \\
\hline & $810 / 318.25$ & 311.32 & $815 / 315.02$ & 5582 & $810 / 318.25$ & & \\
\hline & \multicolumn{5}{|c|}{ Controle } & & \\
\hline & Atuador & Atuador & Atuador & Atuador & $\begin{array}{c}\text { Corrente } \\
\text { Extensométrica }\end{array}$ & & \\
\hline$(\mathrm{mm})$ & $(\mathrm{MPa})$ & (MPa) & $(\mathrm{MPa})$ & (MPa) & $(\mathrm{MPa})$ & $(\mathrm{mm})$ & $(\mathrm{MPa})$ \\
\hline 0,625 & 3,38 & 2,91 & 2,86 & 2,57 & 2,43 & 0,5 & 2,69 \\
\hline 1,25 & 2,25 & 2,74 & 2,95 & 3,40 & 2,69 & 1 & 2,93 \\
\hline 1,875 & 2,64 & 2,84 & 2,67 & 2,99 & 2,67 & 1,5 & 2,98 \\
\hline 2,5 & 2,81 & 2,85 & 2,78 & 2,59 & 2,73 & 2 & 2,95 \\
\hline 3,125 & 2,96 & 2,88 & 2,90 & 2,74 & 2,52 & 2,5 & 2,92 \\
\hline 3,75 & 3,11 & 2,86 & 2,96 & 2,85 & 2,91 & 3 & 2,90 \\
\hline 4,375 & 3,09 & 3,03 & 2,99 & 3,04 & 2,76 & 3,5 & 2,74 \\
\hline
\end{tabular}




\subsection{3.}

Influência do tipo de controle das máquinas de ensaio universal na extensão da instabilidade pós-pico e nas propriedades mecânicas do concreto reforçado com fibras

Visando uma nova forma de realizar o ensaio de duplo puncionamento, estudou-se o uso do controle pela corrente extensométrica e sua influência na extensão da instabilidade pós-pico e nas propriedades mecânicas do concreto reforçado com fibras. As Figuras 84 e 85 mostram o comportamento mecânico do material compósito quando submetido ao ensaio de duplo puncionamento com controles fechado (closed-loop) pelo deslocamento pelo atuador e através da corrente extensométrica. Estudou-se a variação do controle para o concreto com 4,2 $\mathrm{kg} / \mathrm{m}^{3}$ e $25 \mathrm{~kg} / \mathrm{m}^{3}$ de fibras sintéticas (PPF1) e de aço (SF), respectivamente. Os dois tipos de controle foram realizados na MTS810/318.25 e na MTS311.32. A Tabelas 37 mostra os resultados obtidos de tenacidade e de tensão residual para os casos analisados.

Inicialmente, nota-se uma grande mudança no comportamento pós-fissuração do concreto com fibras quando o controle pela corrente extensométrica (closedloop) é executado. Enquanto a aplicação do controle pelo deslocamento do atuador promove uma instabilidade pós-pico do material, o uso do controle pela corrente extensométrica consegue eliminar a perda de informação na região de pósfissuração. Isso se deve ao fato do pistão da máquina se deslocar baseado na taxa de deformação radial da amostra, como explicado por Bernard [85]. Dessa maneira, baseado nos resultados obtidos, o uso do controle pela corrente extensométrica (closed-loop) permite que o comportamento mecânico pós-fissuração seja analisado na sua totalidade, sem perda de informação devido à instabilidade pós-pico.

Em geral, a rigidez da máquina não influenciou no comportamento pósfissuração do concreto com fibras quando o ensaio foi realizado com controle pela corrente extensométrica (closed loop). Diferente do que ocorre no controle pelo deslocamento do atuador, as respostas obtidas nas máquinas MTS810/815.25 e MTS311.32 com o controle externo não apresentaram instabilidade pós-pico. Dessa maneira, obtém-se resultados muito próximos de resistência residual e tenacidade quando o ensaio de duplo puncionamento é realizado com o controle externo para o concreto reforçado com PPF1 e SF. 
C4.2PPF1

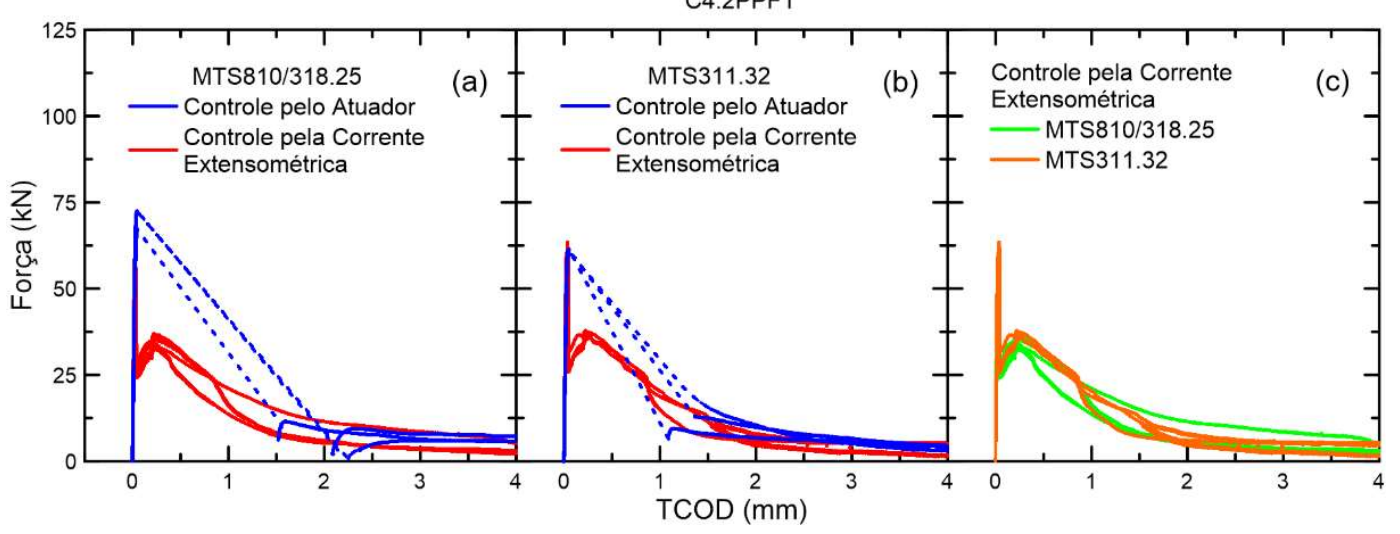

Figura 84 - Comportamento mecânico do concreto reforçado com 4,2 kg/m³ de PPF1 quando

submetido ao ensaio de duplo puncionamento com controles fechados de deslocamento do atuador e externo pela corrente extensométrica: (a) diferentes controles na MTS810/815.25, (b) diferentes controles na MTS311.32 e (c) comparação entre as duas máquinas para o controle pela corrente extensométrica

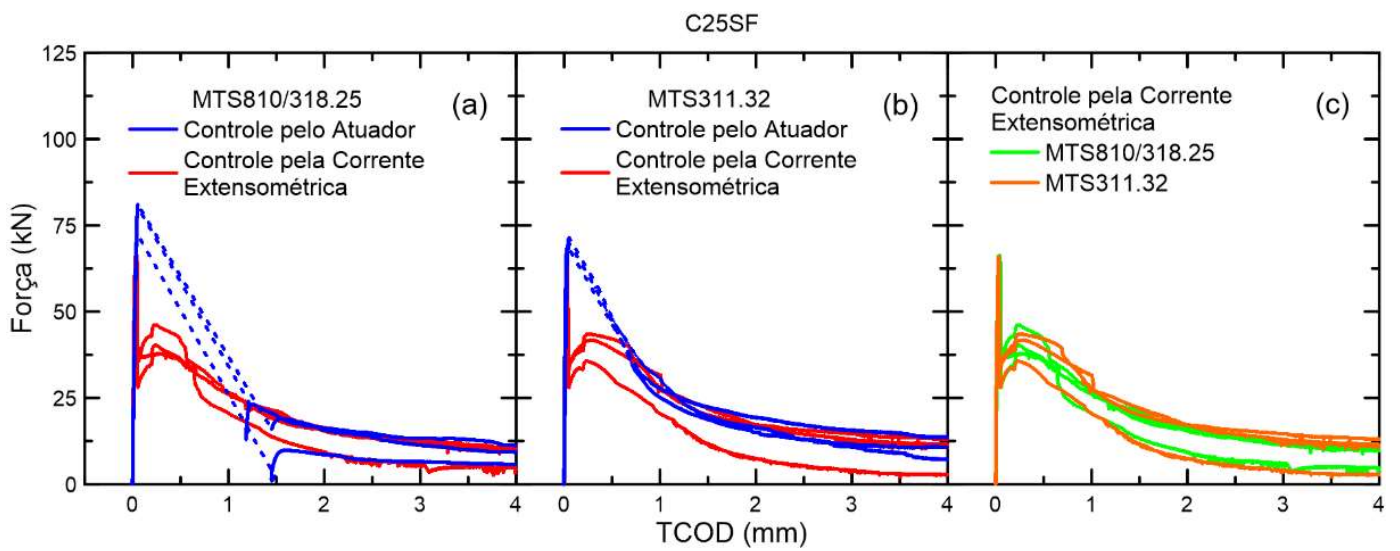

Figura 85 - Comportamento mecânico do concreto reforçado com $25 \mathrm{~kg} / \mathrm{m}^{3}$ de SF quando submetido ao ensaio de duplo puncionamento com controles fechados de deslocamento do atuador e externo pela corrente extensométrica: (a) diferentes controles na MTS810/815.25, (b) diferentes controles na MTS311.32 e (c) comparação entre as duas máquinas para o controle pela corrente extensométrica 
Tabela 37 - Resultados de tenacidade e resistência residual para o ensaio de duplo puncionamento submetido aos controles fechados de deslocamento pelo atuador e externo pela corrente extensométrica. Resultados obtidos para a adição de 4,2 kg/m³ de PPF1 e $25 \mathrm{~kg} / \mathrm{m}^{3}$ de SF. Desvio padrão entre parênteses

\begin{tabular}{cccccccc}
\hline Composição & $\begin{array}{c}\text { Máquina de } \\
\text { Ensaios }\end{array}$ & Controle & $\begin{array}{c}\mathrm{P}_{\mathrm{R}, 0.5} \\
(\mathrm{kN})\end{array}$ & $\begin{array}{c}\mathrm{P}_{\mathrm{R}, 1.5} \\
(\mathrm{kN})\end{array}$ & $\begin{array}{c}\mathrm{P}_{\mathrm{R}, 3.0} \\
(\mathrm{kN})\end{array}$ & $\begin{array}{c}\mathrm{P}_{\mathrm{R}, 4.0} \\
(\mathrm{kN})\end{array}$ & $\begin{array}{c}\mathrm{E}_{\mathrm{BCN}, 4.0} \\
(\mathrm{~J})\end{array}$ \\
\hline \multirow{2}{*}{ C4.2PPF1 } & MTS & \multirow{2}{*}{ Atuador } & 55,33 & 21,30 & 6,70 & 6,20 & 89,19 \\
& $810 / 318.25$ & & $(4,28)$ & $(7,10)$ & $(0,97)$ & $(0,79)$ & $(9,29)$ \\
& $\mathrm{MTS}$ & & 42,17 & 12,01 & 5,72 & 3,89 & 66,59 \\
& 311.32 & Atuador & $(3,69)$ & $(3,87)$ & $(0,71)$ & $(0,77)$ & $(9,75)$ \\
& $\mathrm{MTS}$ & Corrente & 28,50 & 10,18 & 5,18 & 3,50 & 49,09 \\
& $810 / 318.25$ & Extensométrica & $(3,59)$ & $(4,15)$ & $(2,86)$ & $(1,59)$ & $(10.99)$ \\
& $\mathrm{MTS}$ & Corrente & 31,68 & 10,39 & 4,25 & 3,67 & 49,89 \\
& 311.32 & Extensométrica & $(0,87)$ & $(2,92)$ & $(1,56)$ & $(1,87)$ & $(3,39)$ \\
& $\mathrm{MTS}$ & & 56,87 & 15,54 & 10,32 & 8,71 & 94,34 \\
& $810 / 318.25$ & Atuador & $(5,87)$ & $(6,41)$ & $(3,49)$ & $(2,80)$ & $(17,48)$ \\
& $\mathrm{MTS}$ & & 47,48 & 20,24 & 12,62 & 10,48 & 93,81 \\
& 311.32 & Atuador & $(0,27)$ & $(1,84)$ & $(2,60)$ & $(3,20)$ & $(6,97)$ \\
& $\mathrm{MTS}$ & Corrente & 37,87 & 17,70 & 9,83 & 8,21 & 73,14 \\
& $810 / 318.25$ & Extensométrica & $(4,31)$ & $(3,90)$ & $(4,89)$ & $(4,02)$ & $(18,10)$ \\
& MTS & Corrente & 37,34 & 17,80 & 10,28 & 9,02 & 75,38 \\
& 311.32 & Extensométrica & $(5,88)$ & $(5,65)$ & $(5,59)$ & $(5,51)$ & $(21,19)$ \\
\hline
\end{tabular}

Ao comparar tenacidade entre os dois controles, percebe-se a mesma tendência do estudo realizado para máquinas de diferentes rigidezes. Máquinas mais rígidas apresentam menores instabilidades pós-pico promovendo menores valores de tenacidade. No caso do controle pela corrente extensométrica, como não há essa perda de informações após a fissuração do material, os resultados de tenacidade são ainda menores que os obtidos pelo controle de deslocamento. Especialmente para o uso das fibras sintéticas, foi reportado uma variação máxima de $80 \%$ na capacidade de absorção de energia do material na comparação entre os controles.

Em termos de resistência residual, os valores variam significativamente especialmente para níveis de $T C O D$ até $1,5 \mathrm{~mm}$, onde a instabilidade pós-fissuração influencia diretamente o comportamento mecânico. A resposta mecânica entre os controles só aproxima após o fim da instabilidade e as forças residuais se aproximam. Dessa maneira, para que o ensaio de duplo puncionamento apresente 
resultados semelhantes independentemente do tipo e da rigidez da máquina, é necessário realizar o ensaio com controle fechado pela corrente extensométrica.

A Figura 86 mostra uma comparação entre os controles fechados de deslocamento pelo atuador e externo pela corrente extensométrica para o concreto com fibras de aço (SF) em três diferentes frações volumétricas $\left(25,40\right.$ e $\left.60 \mathrm{~kg} / \mathrm{m}^{3}\right)$. A Tabela 38 apresenta os resultados de resistência residual e tenacidade para os casos estudados. Todos os ensaios foram realizados na MTS311.32.

Como já estudado em trabalhos anteriores [85-88], o aumento da fração volumétrica de fibras promove uma diminuição da instabilidade pós-pico. Dessa maneira, ao diminuir essa perda de informação após a fissuração da matriz, os ensaios com controle de deslocamento do atuador se aproximam ao realizados com controle externo tanto em termos de tenacidade quanto de resistência residual. C40SF e C60SF, por sua vez, já apresentam resultados muito semelhantes para todos os parâmetros analisados.

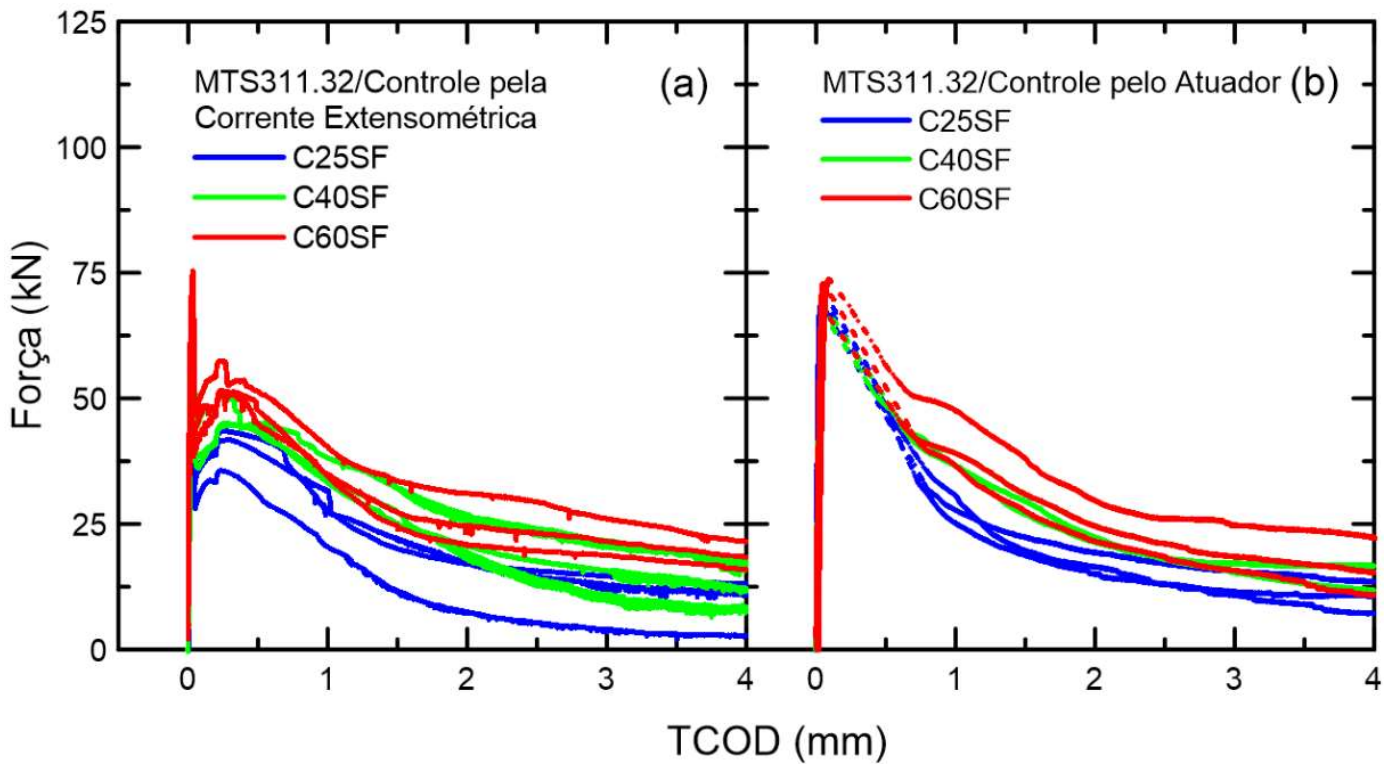

Figura 86 - Comportamento mecânico do concreto reforçado com 25, 40 e 60 kg/m³ de SF quando submetido ao ensaio de duplo puncionamento na MTS311.32 com controles fechados (a) pela corrente extensométrica e (b) pelo deslocamento do atuador 
Tabela 38 - Resultados de resistência de residual e tenacidade para o concreto com 25, 40 e 60 $\mathrm{kg} / \mathrm{m}^{3}$ de fibras SF do ensaio de duplo puncionamento com controles de deslocamento do atuador e externo pela corrente extensométrica. Todos os ensaios foram realizados na MTS311.32. Desvio padrão entre parênteses

\begin{tabular}{|c|c|c|c|c|c|c|c|}
\hline Composição & Controle & $\begin{array}{c}\mathrm{P}_{1} \\
(\mathrm{kN})\end{array}$ & $\begin{array}{l}\mathrm{PR}, 0.5 \\
(\mathrm{kN})\end{array}$ & $\begin{array}{l}\mathrm{PR}, 1.5 \\
(\mathrm{kN})\end{array}$ & $\begin{array}{l}\mathrm{PR}, 3.0 \\
(\mathrm{kN})\end{array}$ & $\begin{array}{l}P_{R, 4.0} \\
(\mathrm{kN})\end{array}$ & $\begin{array}{c}\mathrm{E}_{\mathrm{BCN}, 4.0} \\
(\mathrm{~J})\end{array}$ \\
\hline \multirow{2}{*}{$\mathrm{C} 25 \mathrm{SF}$} & \multirow{2}{*}{ Atuador } & 69,95 & 47,48 & 20,24 & 12,62 & 10,48 & 93,81 \\
\hline & & $(1,33)$ & $(0,27)$ & $(1,84)$ & $(2,60)$ & $(3,20)$ & $(6,97)$ \\
\hline \multirow{2}{*}{ C40SF } & \multirow{2}{*}{ Atuador } & 67,43 & 48,02 & 29,07 & 16,98 & 14,56 & 114,03 \\
\hline & & $(0,90)$ & $(1,19)$ & $(2,04)$ & $(1,60)$ & $(2,50)$ & $(4,77)$ \\
\hline \multirow{2}{*}{ C60SF } & \multirow{2}{*}{ Atuador } & 71,32 & 51,25 & 32,15 & 19,62 & 16,08 & 125,13 \\
\hline & & $(3,43)$ & $(4,62)$ & $(5,44)$ & $(4,58)$ & $(5,69)$ & $(17,26)$ \\
\hline \multirow{2}{*}{$\mathrm{C} 25 \mathrm{SF}$} & Corrente & 64,13 & 37,34 & 17,80 & 10,28 & 9,02 & 75,38 \\
\hline & Extensométrica & $(3,06)$ & $(5,88)$ & $(5,65)$ & $(5,59)$ & $(5,51)$ & $(21,19)$ \\
\hline \multirow{2}{*}{ C40SF } & Corrente & 62,42 & 43,91 & 28,19 & 15,79 & 12,34 & 102,45 \\
\hline & Extensométrica & $(0,90)$ & $(1,00)$ & $(3,60)$ & $(4,99)$ & $(4,44)$ & $(15,04)$ \\
\hline \multirow{2}{*}{ C60SF } & Corrente & 71,06 & 47,93 & 28,23 & 22,08 & 18,62 & 119,90 \\
\hline & Extensométrica & $(3,71)$ & $(3,25)$ & $(4,91)$ & $(3,63)$ & $(2,74)$ & $(15,23)$ \\
\hline
\end{tabular}

6.6.

\section{Conclusão}

A instabilidade pós-fissuração do ensaio de duplo puncionamento aumenta à medida que a rigidez da máquina de ensaios diminui. A variação da instabilidade é mais crítica com o uso das fibras sintéticas, devido ao seu menor módulo de elasticidade.

A capacidade de absorção de energia do concreto com fibras apresenta uma tendência de queda com o aumento da rigidez da máquina. A resistência residual, por sua vez, apresenta grande variabilidade nos primeiros níveis de expansão radial dependendo da máquina utilizada. Essas variações se devem uma queda da instabilidade pós-pico do material, quando submetido ao ensaio de duplo puncionamento com controle fechado de deslocamento do atuador.

Essa variação das propriedades pós-fissuração do material também influencia na correlação entre os ensaios de flexão em três pontos (EN 14651) e duplo puncionamento. Em especial nas correlações entre tensões residuais, as máquinas menos rígidas promovem piores aproximações com os resultados obtidos na flexão devido às maiores instabilidades pós-pico. Dessa maneira, os erros entre os valores 
previstos e os obtidos experimentalmente aumentam com máquinas de menor rigidez. Máquinas menos rígidas, portanto, podem não ser adequadas para esse tipo de análise. No caso das correlações para tenacidade, por outro lado, o erro não variou consideravelmente com o tipo de máquina empregada.

O uso do controle pela corrente extensométrica através da deformação radial da amostra, promoveu a eliminação da instabilidade pós-pico típica observada nos ensaios com controle de deslocamento do atuador. Dessa maneira, como o comportamento pós-fissuração do material é modificado com a escolha do controle, tenacidade e resistência residuais também variam para a mesma fração de fibras adicionada.

Não foi possível observar uma variação significativa das propriedades mecânicas entre as diferentes máquinas estudadas quando foi aplicado controle pela corrente extensométrica. O uso do controle de deformação do material, portanto, independe da rigidez da máquina empregada. Além disso, com o aumento das frações volumétricas de fibra e diminuição da instabilidade pós-pico, tanto a tenacidade quanto a resistência residual se aproximam para os dois controles estudados. A variação dos parâmetros estudados é crítica para pequenas frações volumétricas e para as fibras sintéticas.

O ensaio de duplo puncionamento pode ser uma alternativa para controle tecnológico do concreto com fibras, porém, apresenta grande variação de seus parâmetros mecânicos dependendo da rigidez da máquina de ensaios utilizada. Dessa maneira, recomenda-se a especificação da máquina utilizada e sua rigidez para a correta interpretação dos ensaios de duplo puncionamento. O uso do controle externo pela corrente extensométrica, apesar de tornar o ensaio mais complexo tecnologicamente, é uma alternativa possível para eliminar o efeito da rigidez e propriedades da máquina utilizada. 


\section{Conclusão}

A primeira etapa desse trabalho teve como objetivo melhor entender o comportamento mecânico do concreto projetado com fibras de aço e sintéticas visando sua aplicação em obras de escavação subterrânea. Uma das principais contribuições dessa dissertação de mestrado foi procurar detalhar o dimensionamento do sistema de suporte incluindo o tipo e a fração volumétrica de fibras a serem utilizadas dependendo da qualidade do maciço rochoso estudado. Além disso, verificaram-se inconsistências na classificação do concreto projetado com fibras dependendo da norma adotada para ensaios de flexão em painéis (ASTM C1550 e EN 14488-5). O ensaio de flexão de larga escala vem como alternativa para melhor estudar o comportamento mecânico do concreto fibroso na escala real visualizada nas obras de mineração.

Já na segunda etapa dessa dissertação, foi possível visualizar a influência da variação da rigidez da máquina de ensaios universal na instabilidade pós-fissuração quando o concreto com fibras é submetido ao ensaio de duplo puncionamento. A mudança significativa da instabilidade pós-fissuração, dependendo da máquina utilizada, acarretou em mudanças significativas nas principais propriedades mecânicas do material compósito (capacidade de absorção de energia e tensões residuais), mostrando algumas das limitações desse ensaio para controle tecnológico. O uso do controle externo pela corrente extensométrica, por sua vez, foi efetivo em diminuir a influência da máquina de ensaios nas propriedades mecânicas do concreto com fibras. Por outro lado, escolher esse sistema de controle como padrão pode elevar a complexidade de executar o ensaio de duplo puncionamento nas obras de escavação subterrânea.

Por fim, vale destacar que outros aspectos no uso do concreto projetado com fibras ainda devem ser explorados como a reflexão dos componentes do concreto e, especialmente, das fibras durante a projeção, além de sua aderência na rocha. Em relação ao controle de qualidade, outros ensaios podem ser usados para a análise do material em obras subterrâneas, assim como novas correlações devem ser estudadas 
para uma melhor previsão dos parâmetros estabelecidos nas normas para ensaios de flexão em prismas. 


\section{Referências bibliográfica}

1 WINDSOR, C. Rock reinforcement systems. International Journal of Rock Mechanics and Mining Sciences, vol. 34, n. 6 p. 919-951, 1997

2 BRADY, B; BROWN, E. Rock mechanics for underground mining. $3^{\mathrm{a}}$ ed. New York: Kluwer Academic Publisher, 2004. p.645

3 HUDSON, J; HARRISON, J. Engineering rock mechanics. $1^{\text {st }}$ ed. New York: Pergamon, 1997. $458 \mathrm{p}$.

4 HADJIGEORGIOU, J., POTVIN, Y. SME Mining Engineering Handbook, $3^{\text {rd }}$ ed. Society for Mining, Metallurgy and Exploration, 2011. p. 572-682

5 MORTON, E; VILLAESCUSA, E. Static testing of shotcrete and membranes for mining applications, 6th International Symposium on Ground Support in Mining and Civil Engineering Construction, 2015

6 STACEY, T. Review of membrane support mechanisms, loading mechanisms, desired membrane performance, and appropriate test methods, The Journal of The South African Institute of Mining and Metallurgy, vol. 101, p. 342352,2001

7 CAVERS, D. Simple methods to analyze buckling of rock slopes, Rock Mechanics, vol. 14, p. 87-104, 1981

8 BERNARD, E. Early-age load resistance of fibre reinforced shotcrete linings, Tunnelling and Underground Space Technology, vol. 23, p. 451-460, 2008

9 SEYMOUR, J.; MARTIN, L.; CLARK, C.; STEPAN, M.; JACKSHA, R.; PAKALNIS, R.; ROWORTH, M.; CACERES, C. A shotcrete adhesion test system for mining application, The National Institute for Occupational Safety and Health (NIOSH), 2011

10 HOLMGREN, J. Underground mining methods: Engineering Fundamentals and International Case Studies. Society for Mining, Metallurgy and Exploration, 2001. p. 569-577

11 FERNANDEZ-DELGADO, G; MAHAR, J; PARKER, H. Structural behaviour of thin shotcrete liners obtained from large scale tests, Proceedings of the engineering foundation conference, p. 399-442, 1976

12 BARRETT, S; McCREATH, D. Shotcrete support design in blocky ground: towards a deterministic approach, Tunnels and Deep Space, vol. 10, n. 1, p. 79-89, 1995

13 MORTON, E. Static testing of large scale ground support. Dissertação de Mestrado - Western Australian School of Mines (WASM), 2009 
14 MALMGREN, L; NORDLUND, E; ROLUND, S. Adhesion strength and shrinkage of shotcrete, Tunneling and Underground Space Technology, vol. 20, p. 33-48, 2005

15 MALMGREN, L; SVENSSON, T. Investigation of important parameters for unreinforced shotcrete as rock support in the Kiirunavaara Mine, Sweden, Proceedings of the $37^{\text {th }}$ U.S. Rock Mechanics Symposium, p. 629-635, 1999

16 AUSTRALIAN SHOTCRETE SOCIETY. AuSS. Recommended Practice: Shotcreting in Australia. Australia, 2010

17 ASSOCIAÇÃO BRASILEIRA DE NORMAS TÉCNICAS. NBR 16697: Ciemnto Portland - Requisitos. Rio de Janeiro, 2008.

18 RIXOM, R; MAILVAGANAM, N. Chemical Admixtures for Concrete. $3^{\text {a }}$ ed. London: E \& FN Span, 1999. p.228

19 EUROPEAN FEDERATION OF NATIONAL ASSOCIATIONS REPRESENTING FOR CONCRETE. EFNARC: European Specification for Sprayed Concrete, 1996

20 MEHTA, P; MONTEIRO, PAULO. Concrete: microstructure, properties and materials. $3^{\mathrm{a}}$ ed. London: McGraw-Hill, 2006.

21 ARMELIN, HS; BANTHIA, DR; MORGAN, DR; STEEVES, C. Rebound in Dry-Mix Shotcrete, Concrete International, vol. 19, p. 54-60, 1997

22 ARMENGAUD, J; CASAUX-GINESTET, G; CYR, M; HUSSON, B; JOLIN, M. Characterization of fresh dry-mix shotcrete and correlation to rebound, Construction and Building Materials, vol. 135, p. 225-232, 2017

23 PFEUFFER, M; KUSTERLE, W. Rheology and rebound behavior of dry-mix shotcrete, Cement and Concrete Research, vol. 31, p. 1619-1625, 2001

24 HEWLETT, P. Lea's Chemistry of Cement and Concrete. $4^{\mathrm{a}}$ ed. Elsevier Science \& Technology Books, 2004

25 PRUDENCIO JR, L. Accelerating admixtures for shotcrete. Cement and Concrete Composites, vol. 20, p. 213-219, 1998

26 AMERICAN CONCRETE INSTITUTE. ACI 506.1R-98: Guide to FiberReinforced Shotcrete. United States, 1998

27 AMERICAN CONCRETE INSTITUTE. ACI 544.4R:2018: Guide to Design with Fiber-Reinforced Concrete. United States, 2018

28 LOUCHNIKOV, V; SANDY, M; WATSON, O; ORUNESU, M; EREMENKO, V. An overview of surface rock support for deformable ground conditions. 12 ${ }^{\text {th }}$ AusIMM Underground Operators' Conference, 2014

29 JOLIN, M; BEAUPRÉ, D. Understanding Wet-Mix Shotcrete: Mix Design, Specifications, and Placement. Surface Support Liners Conference, 2003

30 LIU, G; CHENG, W; CHEN, L. Investigating and optimizing the mix proportion of pumping wet-mix shotcrete with polypropylene fiber. Construction and Building Materials, vol. 150, p. 14-23, 2017

31 HOEK, E; BROWN, T. Underground excavations in rock. $1^{\text {a }}$ ed. London: E \& FN SPON, 1982 
32 BENTUR, A.; MINDESS, S. Fibre Reinforced Cementitious Composites. 2.ed. Taylor \& Francis, 2007

33 AMERICAN CONCRETE INSTITUTE. ACI 544.4R:1996: Report on Fiber Reinforced Concrete. United States, 1996

34 FIGUEIREDO, A. Concreto Reforçado Com Fibras. Tese de Livre Docência - Universidade de São Paulo, 2011.

35 HOEK, E; KAISER, P; BAWDEN, W. Support of Underground Excavations in Hard Rock. Funding by Mining Research Directorate and Universities Research Incentive Fund, 1993

36 RAFFALDI, M; WARREN, S; MARTN, L; STEPAN, M; PAKALNIS, R; SANDBAK, L. Reinforced Shotcrete Performance: Quantifying the Influence of Ground Support Installation Sequence. 52 ${ }^{\text {nd }}$ US Rock Mechanics/Geomechanics Symposium, 2018

37 MARTIN, L; CLARK, C; JOHNSON, J; STEPAN, M. A new high force and displacement shotcrete test. Proceedings of the SME Annual Conference, 2015.

38 GRIMSTAD, E; BARTON, N. Updating of the Q-System for NMT. Proceedings of the International Symposium on Sprayed Concrete Modern Use of Wet Mix Sprayed Concrete for Underground Support, 1993.

39 BIENIAWSKI, Z. (1976) Rock Mass Classification in Rock Engineering. Symposium Proceedings of Exploration for Rock Engineering, vol. 1, 1976

40 WICKHAM, G; TIEDEMANN, H; SKINNER, E. Ground support prediction model (RSR Concept). Proceedings of Rapid Excavation and Tunneling Conference, 1971

41 HOEK, E. Practical rock engineering. Evert Hoek Consulting Engineer Inc, 2006

42 BIENIAWSKI, Z. Engineering rock mass classifications. $1^{\text {a }}$ ed. John, Wiley \& Sons, 1989

43 BARTON, N; LIEN, R; LUNDE, J. Engineering classification of rock masses for the design of tunnel support. Rock Mechanics, vol. 6, p. 189-236, 1974

44 GOODMAN, R. Introduction to rock mechanics. $2^{\mathrm{a}}$ ed. New York: John, Wiley \& Sons, 1989

45 DEERE, DU; DEERE DW. The rock quality designation (RQD) index in practice. Rock classification systems for engineering purposes. ASTM Special Publication, vol. 984, p. 91-101, 1988

46 GRIMSTAD, E; BARTON, N. Updating the Q-system for NMT. Proceedings of the International Symposium on Sprayed Concrete, p.46-56, 1993

47 PALMSTROM, A; BROCH, E. Use and misuse of rock mass classification systems with particular reference to the Q-system. Tunnelling and Underground Space Technology, vol. 21. P. 575-593, 2006

48 PAPWORTH, F. Design guidelines for the use of fibre reinforced shotcrete in ground support. $27^{\text {th }}$ Conference on Our World in Concrete \& Structures, 429-436, 2002 
49 AMERICAN SOCIETY FOR TESTING AND MATERIALS. ASTM C155016: Flexural toughness of fiber reinforced concrete (using centrally loaded round panel). United States, 2016

50 EUROPEAN STANDARD. BS EN 14488-5:2006: Testing sprayed concrete - Part 5: Determination of energy absorption capacity of fibre reinforced slab specimens. Brussels, 2006

51 CASTOLDI, R. Propriedades mecânicas e durabilidade de concretos reforçados com fibras de polipropileno e sisal. Dissertação de Mestrado Pontifícia Universidade Católica do Rio de Janeiro (PUC-Rio), 2018

52 AMERICAN SOCIETY FOR TESTING AND MATERIALS. ASTM C160912: Flexural performance of fiber reinforced concrete (using beam with thirdpoint loading). United States, 2016

53 RÉUNION INTERNATIONALE DES LABORATOIRES ET EXPERTS DES MATÉRIAUX. RILEM TC 162-TDF: Test and design methods for steel fibre reinforced concrete. Materials and Structures, 2003

54 EUROPEAN STANDARD. BS EN 14651-2005: Test method for metallic concrete - Measuring the flexural tensile strength (limit of proportionality (LOP), residual), 2005

55 FÉDÉRATION INTERNATIONALE DU BÉTON. CEB-FIB: Model Code. $1^{\mathrm{a}}$. ed. Lausanne: International Federation for Structural Concrete (FIB), vol. 2, p. 331,2012

56 MOBASHER, B.; YAO, Y.; SORANAKOM, C. Analytical solutions for flexural design of hybrid steel fiber reinforced concrete beams. Engineering Structures, p. 164-177, 2015

57 MINElli, F.; PlizZARI, G. A New Round Panel Test for the Characterization of Fiber Reinforced Concrete: A Broad Experimental Study. Journal of Testing and Evaluation, p. 889-897, 2011

58 SALVADOR, R. Análise comparativa de comportamento mecânico de concreto reforçado com macrofibra polimérica e com fibra de aço. Dissertação de Mestrado - Universidade de São Paulo, 2013

59 MINELLI, F.; PLIZZARI, G. Fiber reinforced concrete characterization through round panel test - part I: experimental study. Proceedings of FraMCoS-7, 2010

60 NITSCHKE, A; WINTERBERG, R. Performance of macro synthetic fiber reinforced tunnel linings. Proceedings of the 2016 World Tunneling Congress, 2016

61 BERNARD, E. Behaviour of round steel fibre reinforced concrete panels under point loads. Materials and Structures, vol. 33, p. 181-188, 2000

62 BERNARD, E; XU, G; CARINO, N. Precision of the ASTM C1550 panel test and field variation in measured FRS performance. Shotcrete: Elements of a system, Taylor \& Francis Group, 2010

63 MARTIN, L; CLARK, C; SEYMOUR, J; STEPAN, M. Shotcrete Design and Installation Compliance Testing: Early Strength, Load Capacity/Toughness, Adhesion Strength, and Applied Quality. Department of Health and Human 
Services, Centers for Disease Control and Prevention, National Institute for Occupational Safety and Health, DHHS(NIOSH), 2015

64 CLEMENTS, J; BERNARD, E. The Use of Macro-Synthetic Fiber-Reinforced Shotcrete in Australia. Shotcrete Magazine, 2004

65 DECKER, J; MADSEN, P; GALL, V; O'BRIEN, T. Use of Synthetic, FiberReinforced, Initial Shotcrete Lining at Devil's Slide Tunnel Project in California. Journal of the Transportation Research Board, vol. 2313, p. 147-154, 2012

66 CENGIZ, O; TURANLI, L. Comparative evaluation of steel mesh, steel fibre and high performance polypropylene fibre reinforced shotcrete in panel test. Cement and Concrete Research, vol. 34, p. 1357-1364, 2004

67 RATCLIFFE, R. Fibre reinforcement - Steel vs. Macro (Structural) Synthetic. Concrete Beton, vol. 115, p. 16-20, 2007

68 MOBASHER, B. Mechanics of Fiber and Textile Reinforced Cement Composites. $1^{\text {st }}$ ed. CRC Press, 2019

69 DING, Y; KUSTERLE, W. Comparative study of steel-reinforced concrete and steel mesh-reinforced concrete at early ages in panel tests. Cement and Concrete Research, vol. 29, p.1827-1834, 1999

70 VANDEWALLE, M. The of steel fibre reinforced shotcrete for the support of mine openings. The Journal of the South African Institute of Mining and Metallurgy, vol. 98, p. 113-120, 1998

71 YANG, J; KIM, J; YOO, D. Performance of shotcrete containing amorphous fibers for tunnel applications. Tunnelling and Underground Space Technology, vol. 64, p. 86-94, 2017

72 KAUFMANN, J; FRECH, K; SCHUETZ, P; MÜNCH, B. Rebound and orientation of fibers in wet sprayed concrete applications. Construction and Building Materials, vol. 40, p. 15-22, 2013

73 HOLMGREN, J. Bolt-anchored, steel-fibre-reinforced shotcrete linings. Tunneling and Underground Space Technology, vol. 2, p. 319-333, 1987

74 CHEN, W. F. Double punch test for tensile strength of concrete. ACI Materials Journal, vol. 67, p. 993-995, 1970

75 SALUDES, S. R. Ensayo de doble punzonamiento aplicado al hormigón reforzado con fibras (Ensayo Barcelona). Dissertação de Mestrado Universidad Politecnica de Catalunya (UPC), 2006

76 ASOCIACIÓN ESPAÑOLA DE NORMALIZACIÓN Y CERTIFICACIÓN. UNE 83515: Hormigones con fibras. Determinación de la resistencia a fisuración, tenacidad y resistencia residual a tracción. Método Barcelona. Barcelona, 2010.

77 PUJADAS, P. Caracterización y diseño del hormigón reforzado com fibras plásticas. 2013. Tese de Doutorado - Universidad Politecnica de Catalunya (UPC), 2013

78 BLANCO, A; PUJADAS, P; CAVALARO, S; DE LA FUENTE, A; AGUADO, A. Constitutive model for fibre reinforced concrete based on the Barcelona test, Cement \& Concrete Composites, vol. 53, p. 327-340, 2014 
79 RAMBO, D; BLANCO, A; FIGUEIREDO, A; DOS SANTOS, E; TOLEDO FILHO, R; GOMES, O. Study of temperature effect on macro-synthetic fiber reinforced concretes by means of Barcelona tests: an approach focused on tunnels assessment. Construction and Building Materials, vol. 158, p. 443453, 2018

80 CARDOSO, DCT; PEREIRA, GBS; SILVA, FA; SILVA FILHO, JJH; PEREIRA, EV. Influence of steel fibers on the flexural behavior of RC beams with low reinforcing ratios: Analytical and experimental investigation. Composite and Structures, vol. 222, 2019

81 SILVA, FA; BUTLER, M; MECHTCHERINE, V; ZHU, D; MOBAHSER, B. Strain rate effect on the tensile behaviour of textile-reinforced concrete under static and dynamic loading. Materials Science and Engineering A, vol. 528, p. $1727-1734,2011$

82 WILLE, K; EL-TAWIL, S; NAAMAN, AE. Properties of strain hardening ultra high performance fiber reinforced concrete (UHP-FRC) under direct tensile loading. Cement \& Concrete composites, vol. 48, p. 53-66, 2014

83 CAVALARO, SHP; AGUADO, A. Intrinsic scatter of FRC: an alternative philosophy to estimate characteristic values. Materials and Structures, vol. 48, p. 3537-3555, 2015

84 MOLINS, C; AGUADO, A; SALUDES, S. Double punch test to control the energy dissipation in tension of FRC (Barcelona test). Materials and Structures, vol. 42, p.415-425, 2009

85 CARMONA, S; MOLINS, C; AGUADO, A. Correlation between bending test and Barcelona tests to determine FRC properties. Construction and Building Materials, vol. 181, p. 673-686, 2018

86 CARMONA, S; MOLINS, C. Use of BCN test for controlling tension capacity of fiber reinforced shotcrete in mining works. Construction and Building Material, vol. 198, p. 399-410, 2019

87 GALEOTE, E; BLANCO, A; CAVALARO, S; DE LA FUENTE, A. Correlation between the Barcelona test and the bending test in fibre reinforced concrete. Construction and Building Materials, vol. 152, p. 529-538, 2017

88 CARMONA, S; AGUADO, A; MOLINS, C. Generalization of the Barcelona test for the toughness control of FRC. Materials and Structures, vol. 45, p. 1053-1069, 2012

89 MONTE, R. Caracterização e controle do comportamento mecânico do concreto reforçado com fibras para tubos. Tese de Doutorado - Universidade de São Paulo (USP), 2015

90 GALOBARDES, I; SILVA, C; FIGUEIREDO, A; CAVALARO, S; GOODIER, C. Alternative quality control of steel fibre reinforced sprayed concrete (SFRSC). Construction and Building Materials, vol. 223, p. 10081015,2019

91 SIMÃO, L. Estudo de sistemas de controle para o ensaio de duplo puncionamento. Dissertação de Mestrado - Universidade de São Paulo (USP), 2019 
92 BANTHIA, N; DUBEY A. Measurement of Flexural Toughness of Fiber Reinforced Concrete Using a Novel Technique-Part 1: Assessment and Calibration. ACI Materials Journal, vol. 96, p. 651-656, 1999

93 GETTU, R; MOBASHER, B; CARMONA, S; JANSEN, D. Testing of concrete under closed-loop control. Advanced Cement Based Materials, vol. 3, p. 54-71, 1996

94 BERNARD, E. Influence of Test Machine Control Method on flexural Performance of Fiber Reinforced Concrete Beams. Journal of ASTM International, vol. 6, p. 3-11, 2009

95 BANTHIA, N; MINDESS, S; JIANG. Z. Influence of Feedback Control on Flexural Toughness of Fiber Reinforced Concrete in ASTM C1399 Tests. Journal of Testing and Evaluation, vol. 39, p. 664-670, 2012

96 SIMÃO, L; NOGUEIRA, A; MONTE, R; SALVADOR, R; FIGUEIREDO, A. Influence of the instability of the double punch test on the post-crack response of fiber-reinforced concrete. Construction and Building Materials, vol. 217, p. $185-192,2019$

97 BARBOSA, E. Avaliação do suporte com cabos de aço na Mina Cuiabá (Sabará/MG). Dissertação de Mestrado - Universidade Federal de Ouro Preto, 2008

98 LIBBY, D. As minerações estrangeiras em Minas: o escravo e o sistema fabril. População e mão-de-obra na província de Minas Gerais. (1830-1889). Tese de Doutorado - Universidade de São Paulo (USP), 1987

99 AZEVEDO, U; MACHADO, M; CASTRO, P; RENGER, F; TREVISOL, A; BEATO, D. Geoparque Quadrilátero Ferrífero (MG): proposta. Repositório Institucional de Geociências - CPRM, 2012

100 PEREIRA, F. Interpretação do overbreak da rampa Fonte Grande Sul (Mina Cuiabá) e sua interação com o sistema de suporte. Dissetação de Mestrado Universidade Federal de Ouro Preto (UFOP), 2016

101 BALTAZAR, E; ZUCHETTI. Lithofacies associations and structural evolution of the Archean Rio das Velhas greenstone bel, Quadrilátero Ferrífero, Brazil: A review of the setting of gold deposits. Ore Geology Reviews, vol. 32, p. 471-499, 2007

102 LOBATO, L; RIBEIRO-RODRIGUES,, L; VIEIRA, F. Brazil's premier gold province. Part II: geology and genesis of gold deposits in the Archean Rio das Velhas greenstone belt, Quadrilátero Ferrífero. Mineralium Deposita, vol. 36, 249-277, 2001

103 TOLEDO, C. Controle estrutural da mineralização aurífera na mina de Cuiabá, setor noroeste do greenbelt belt Rio das Velhas, Quadrílatero Ferrífero, MG. Dissertação de Mestrado - Universidade Estadual de Campinas (UNICAMP), 1997

104 TRÓPIA, I. Análise das tensões in situ em ambiente de lavra subterrânea mina Cuiabá - Sabará/MG. Dissertação de Mestrado - Universidade Federal de Ouro Preto (UFOP), 2013 
105 OLIVEIRA, M. Dimensionamento empírico de realce em sublevel stoping. Dissertação de Mestrado - Universidade Federal de Minas Gerais (UFMG), 2012

106 COSTA, L; PADULA, R; PIMENTA, L; PEREIRA, R; PETERLE, D. Support and reinforcement damage initiation and design in a deep mine environment. Case study: Cuiabá Mine, Minas Gerais, Brazil. Proceedings of the Ninth International Conference on Deep and High Stress Mining, 2019

107 EUROPEAN STANDARD. BS EN 14488-2: Testing sprayed concrete - Part 2: Compressive strength of young sprayed concrete, 2006

108 NORMA PORTUGUESA. NP EN 14487-1: Betão projectado: definições, especificações e conformidade, 2008

109 ASSOCIAÇÃO BRASILEIRA DE NORMAS TÉCNICAS. NBR 5733: Cimento Portland de alta resistência inicial. Rio de Janeiro, 1991

110 ASSOCIAÇÃO BRASILEIRA DE NORMAS TÉCNICAS. NBR NM 248: Agregados - Determinação da composição granulométrica. Rio de Janeiro, 2003

111 ASSOCIAÇÃO BRASILEIRA DE NORMAS TÉCNICAS. NBR 11768: Aditivos químicos para concreto de cimento Portland. Rio de janeiro, 2011.

112 MEHTA, P. K.; MONTEIRO, P. J. M. Concrete: Microstructure, Properties, and Materials. $3^{3}$. ed. New York: McGraw-Hill, 2006

113 ASSOCIAÇÃO BRASILEIRA DE NORMAS TÉCNICAS. NBR 5739: Concreto - Ensaio de Compressão de Corpos de Prova Cilíndricos 2007

114 ZHANDAROV, S; MÄDER, E. Characterization of fiber/matrix interface strength: applicability of different tests, approaches and parameters. Composites Science and Technology, vol. 65, p. 149-160, 2005

115 NOGUEIRA, V. Fluência e propriedades mecânicas de compósitos cimentícios reforçados com fibra de aço e polipropileno. Dissertação de Mestrado - Pontifícia Universidade Católica do Rio de Janeiro (PUC-Rio), 2019

116 CASTOLDI, R; DE SOUZA, L; SILVA, F. Comparative study on the mechanical behavior and durability of polypropylene and sisal fiber reinforced concretes. Construction and Building Materials, vol. 211, p. 617-628, 2019

117 MONTEIRO, V; LIMA, L; SILVA, F. On the mechanical behavior of polypropylene, steel and hybrid fiber reinforced self-consolidating concrete. Construction and Building Materials, vol. 188, p. 280-291, 2018

118 DI MAIDA, P; RADI, E; SCIANCALEPORE, C; BONDIOLI, F. Pullout behavior of polypropylene macro-synthetic fibers treated with nano-silica. Cement and Concrete Composites, vol. 82, p. 39-44, 2015

119 BABAFEMI, A; PLESSIS, A; BOSHOFF, W. Pull-out creep mechanism of synthetic macro fibres under a sustained load. Construction and Building Materials, vol. 174, p. 466-473, 2018

$120 \mathrm{KIM}$, J; YOO, D. Effects of fiber shape and distance on the pullout behavior of steel fibers embedded in ultra-high-performance concrete. Construction and Building Materials, vol. 103, p. 213-223, 2019 
121 TAI, Y; EL-TAWIL, S; CHUNG, T. Performance of deformed steel fibers embedded in ultra-high performance concrete subjected to various pullout rates. Cement and Concrete Research, vol. 89, p. 1-13, 2016

122 GHODDOUSI, P; AHMADI, R; SHARIFI, M. Fiber pullout model for aligned hooked-end steel fiber. Can J Civ Eng, vol. 37, p. 1179-88, 2010

123 RAMBO, D. Concretos autoadensáveis reforçados com fibras de aço híbridas: aspectos materiais e estruturais. Dissertação de Mestrado Universidade Federal do Rio de Janeiro (UFRJ), 2012

124 ADUSUMALLI, R; VENKATESHAN, K; KUNCHI, C; VADLAMANI, R. Tensile testing of single fibers. Procedia Structural Integrity, vol. 14, p. 150157,2019

125 MANSUR, R. Comportamento mecânico de concretos têxteis reforçados com tecido de carbono: aspectos materiais e estruturais. Dissertação de Mestrado - Pontifícia Universidade Católica do Rio de Janeiro (PUC-Rio), 2018

126 AMERICAN SOCIETY FOR TESTING AND MATERIALS. ASTM C1399: Standard test method for obtaining average residual-strength of fiber reinforced concrete United States, 2015 


\section{Apêndice}

Cálculo da rigidez do pórtico de uma máquina de ensaios universal

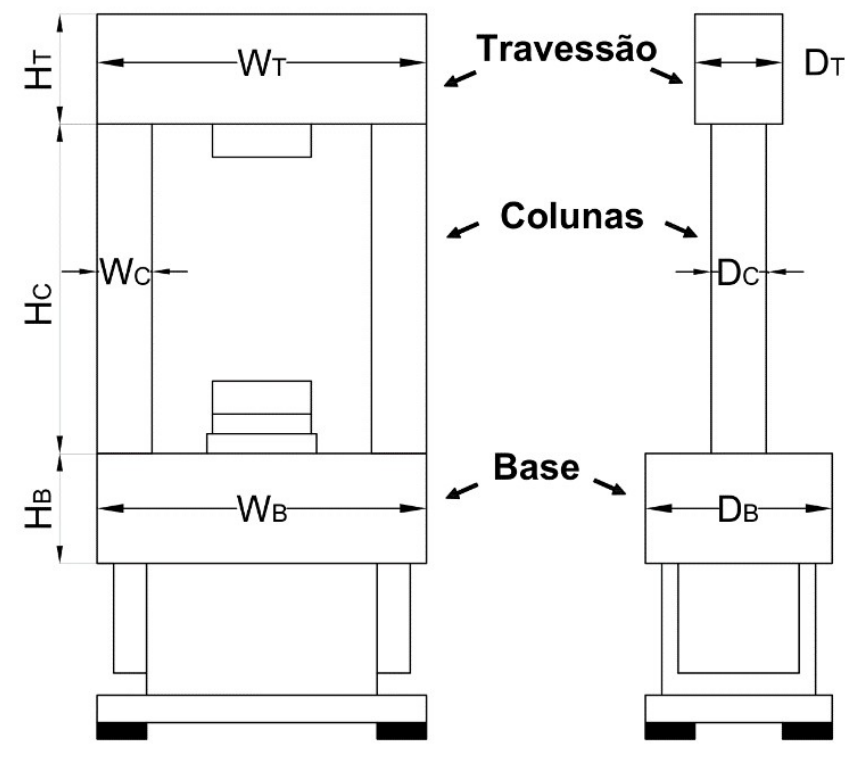

(a)

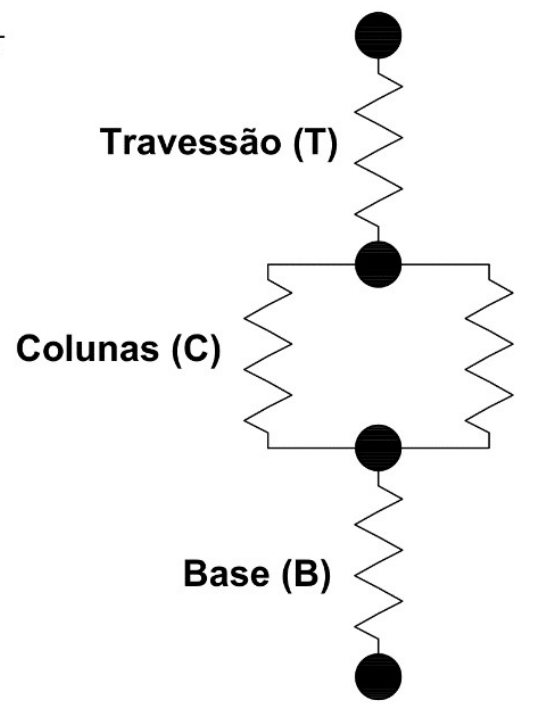

(b)

Figura 87 - Pórtico modelo: (a) detalhe das dimensões da base, das colunas e do travessão do pórtico e (b) modelo teórico para cálculo da rigidez

A partir das equações 12-23, é possível estimar a rigidez do sistema levando em consideração a rigidez da base, das colunas e do travessão do pórtico estudado na Figura 87.

$$
\begin{aligned}
& I_{T}=\frac{D_{T}\left(H_{T}\right)^{3}}{12}
\end{aligned}
$$

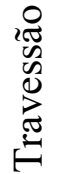

$$
\begin{aligned}
& L_{T}=W_{T}-2 W_{C} \\
& A_{T}=D_{T} H_{T}
\end{aligned}
$$




$$
\begin{array}{ll}
\text { है } & A_{C}=D_{C} W_{C} \\
\text { 吾 } & L_{C}=H_{C}
\end{array}
$$

$$
I_{B}=\frac{D_{B}\left(H_{B}\right)^{3}}{12}
$$

总 $\quad L_{B}=W_{B}-2 W_{B}$

$$
A_{B}=D_{B} H_{B}
$$

$$
K_{T}=\left[\left(\frac{48 E I_{T}}{L_{T}^{3}}\right)^{-1}+\left(\frac{20 A_{T} G}{6 L_{T}}\right)^{-1}\right]^{-1}
$$

$$
\begin{array}{ll}
K_{C}=\frac{A_{C} E}{L_{C}} \\
K_{B}=\left[\left(\frac{48 E I_{B}}{L_{B}^{3}}\right)^{-1}+\left(\frac{20 A_{B} G}{6 L_{B}}\right)^{-1}\right]^{-1} \\
K_{\text {sistema }}=\left[K_{T}^{-1}+\left(2 K_{C}\right)^{-1}+K_{B}^{-1}\right]^{-1}
\end{array}
$$

onde A é a área, D a profundidade, E o módulo de elasticidade, G o módulo de cisalhamento, $\mathrm{H}$ a altura, $\mathrm{I}$ o momento de inércia, $\mathrm{K}$ a rigidez, $\mathrm{L}$ o comprimento e W a largura.

Apesar da rigidez da base ser estimada como um sólido maciço retangular, na prática, a base apresenta diversos espaços vazios. É assumido que, como o atuador é montado na base da máquina de ensaios, a rigidez da base somada à rigidez do atuador é comparável a um sólido retangular maciço.

Pode-se analisar abaixo a memória de cálculo para análise da rigidez do pórtico da MTS810/318.25, utilizada nesse trabalho. Assumiu-se o material aço para todos os elementos do pórtico. O fabricante indica uma altura do travessão de $1270 \mathrm{~mm}$ em relação à base para esse cálculo. A partir do modelo, foi possível estimar 4,20x $10^{8} \mathrm{~N} / \mathrm{m}$ para a rigidez da MTS810/318.25, valor próximo ao indicado pelo fabricante de $4,30 \times 10^{8} \mathrm{~N} / \mathrm{m}$. 
Tabela 39 - Memória de cálculo para estimar a rigidez da MTS810/318.25

\begin{tabular}{|c|c|c|c|c|c|}
\hline \multicolumn{2}{|c|}{ Travessão } & \multicolumn{2}{|c|}{ Colunas } & \multicolumn{2}{|c|}{ Base } \\
\hline $\mathrm{H}_{\mathrm{T}}(\mathrm{mm})$ & 255 & $\mathrm{~W}_{\mathrm{C}}(\mathrm{mm})$ & 76 & $\mathrm{H}_{\mathrm{B}}(\mathrm{mm})$ & 120 \\
\hline $\mathrm{W}_{\mathrm{T}}(\mathrm{mm})$ & 900 & $\mathrm{H}_{\mathrm{C}}(\mathrm{mm})$ & 1270 & $\mathrm{~W}_{\mathrm{B}}(\mathrm{mm})$ & 1000 \\
\hline $\mathrm{D}_{\mathrm{T}}(\mathrm{mm})$ & 110 & $\mathrm{D}_{\mathrm{C}}(\mathrm{mm})$ & 76 & $\mathrm{D}_{\mathrm{B}}(\mathrm{mm})$ & 365 \\
\hline $\mathrm{E}(\mathrm{MPa})$ & 200000 & $\mathrm{E}(\mathrm{MPa})$ & 200000 & $\mathrm{E}(\mathrm{MPa})$ & 200000 \\
\hline $\mathrm{G}(\mathrm{MPa})$ & 75000 & $\mathrm{G}(\mathrm{MPa})$ & 75000 & $\mathrm{G}(\mathrm{MPa})$ & 75000 \\
\hline $\mathrm{I}_{\mathrm{T}}\left(\mathrm{mm}^{4}\right)$ & 151995938 & $\mathrm{~A}_{\mathrm{C}}\left(\mathrm{mm}^{2}\right)$ & 4536 & $\mathrm{I}_{\mathrm{B}}\left(\mathrm{mm}^{4}\right)$ & 52560000 \\
\hline $\mathrm{L}_{\mathrm{T}}(\mathrm{mm})$ & 748 & $\mathrm{~L}_{\mathrm{C}}(\mathrm{mm})$ & 1270 & $\mathrm{~L}_{\mathrm{B}}(\mathrm{mm})$ & 848 \\
\hline $\mathrm{A}_{\mathrm{T}}\left(\mathrm{mm}^{2}\right)$ & 28050 & \multirow{2}{*}{$\mathrm{K}_{\mathrm{C}}(\mathrm{N} / \mathrm{mm})$} & \multirow{2}{*}{$7,14 \mathrm{E}+05$} & $\mathrm{~A}_{\mathrm{B}}\left(\mathrm{mm}^{2}\right)$ & 43800 \\
\hline $\mathrm{K}_{\mathrm{T}}(\mathrm{N} / \mathrm{mm})$ & $2,54 \mathrm{E}+06$ & & & $\mathrm{~K}_{\mathrm{B}}(\mathrm{N} / \mathrm{mm})$ & $7,78 \mathrm{E}+05$ \\
\hline \multicolumn{3}{|c|}{$K_{\text {sistema }}(\mathrm{N} / \mathrm{m})$} & & $4,20 \mathrm{E}+08$ & \\
\hline
\end{tabular}

